\title{
$g^{*}$ ?
}

\begin{tabular}{l|l}
$\begin{array}{l}\text { 2. To: (Receiving organization) } \\
\text { Distribution }\end{array}$ & $\begin{array}{l}\text { 3. From: Coriginating Organization) } \\
\text { Data Assessment and } \\
\text { Interpretation }\end{array}$ \\
\hline $\begin{array}{l}\text { 5. Proj./Prog./Dept./Div.: } \\
\text { Tank 241-S-101/Waste } \\
\text { Management/DAI/TWS } \\
\text { Technica? Basis }\end{array}$ & $\begin{array}{l}\text { 6. Design Authority/ Design Agent/Cog. } \\
\text { Engr.: }\end{array}$ \\
\hline $\begin{array}{l}\text { 8. originator Renarks: } \\
\text { This document is being released into the supporting document } \\
\text { system for retrievability purposes. }\end{array}$
\end{tabular}

11. Receiver Renarks:

For release.
4. Related EDT No.:
N/A

7. Purchase Order No.:

N/A

9. Equip./Component No.: $N / A$

10. System/Bldg./Facility: 241-S-101

12. Major Assm. Dwg. No.:

$N / A$

13. Permit/Permit Application No.: $N / A$

14. Required Response Date: $08 / 30 / 96$

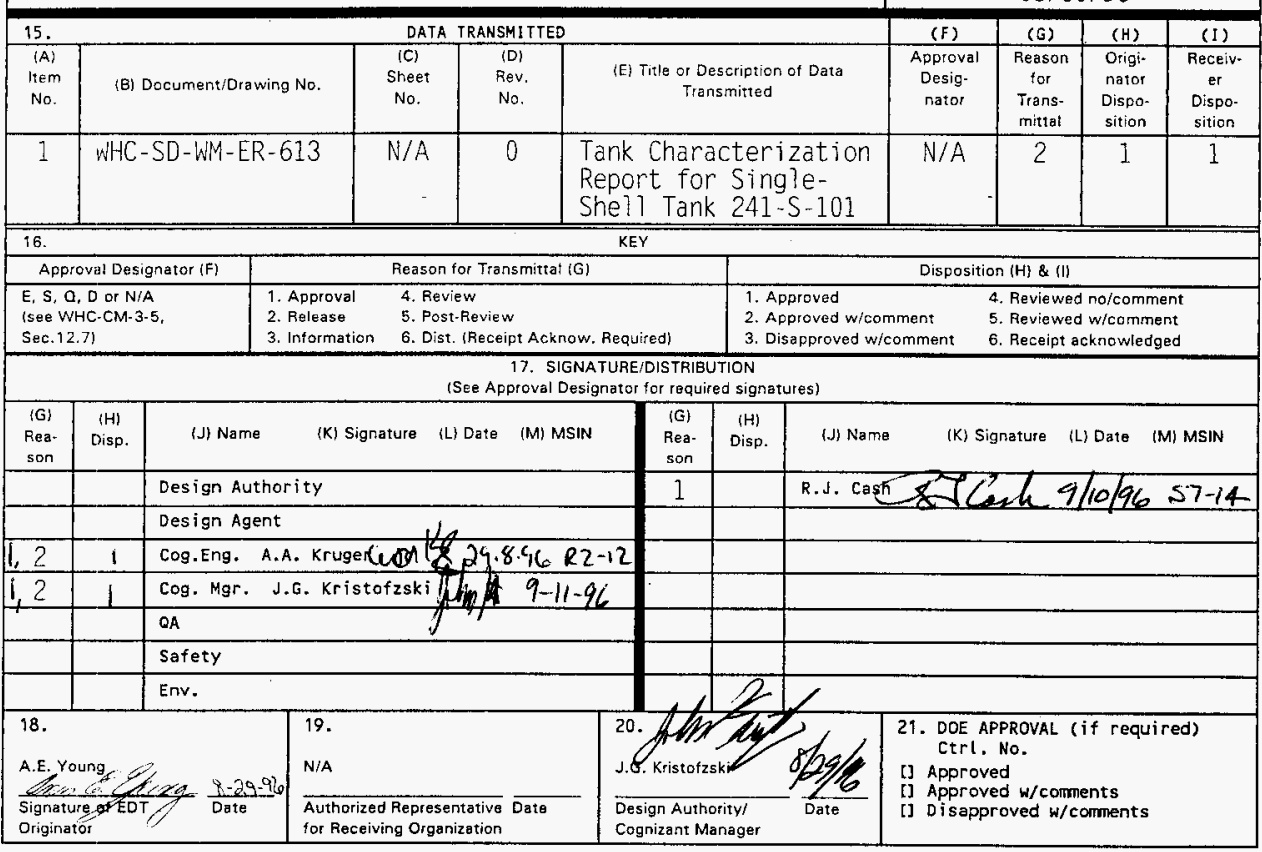

8D-7400-172-2 (05/96) GEF097 


\section{Tank Characterization Report for Single-Shell Tank 241-S-101}

Albert A. Kruger

Westinghouse Hanford Company. Richland, WA 99352

U.S. Department of Energy Contract DE-AC06-87RL10930

$\begin{array}{lll}\text { EDT/ECN: } & \text { EDT }-617535 & \text { UC: } 2070 \\ \text { Org Code: } & 79400 & \text { Charge Code: N4G4D } \\ \text { B\&R Code: } & \text { EW } 3120074 & \text { Total Pages: } \boldsymbol{2}>6\end{array}$

Key words: Tank Characterization Report, TCR, Tank 241-S-101. Tank S101, S-101, S Farm, Single-She11. SST. Milestone M-44-09

Abstract: This document summarizes the information on the historical uses, present status, and the sampling and analysis results of waste stored in tank 241-S-101. This report supports the requirements of TriParty Agreement Mi lestone M-44-09.

TRADEMARK DISCLAIMER. Reference herein to any specific commercial product, process, or service by trade name, trademark, manufacturer, or otherwise, does not necessarily constitute or imoly its endorsement, recommendation, or favoring by the United States Government or any agency thereof or its contractors or subcontractors.

Printed in the United States of America. To obtain copies of this document, contact: WHC/BCS Document Control Services, P.O. Box 1970, Mailstop H6-08, Richland WA 99352, Phone (509) 372-2420; Fax (509) 376-4989.
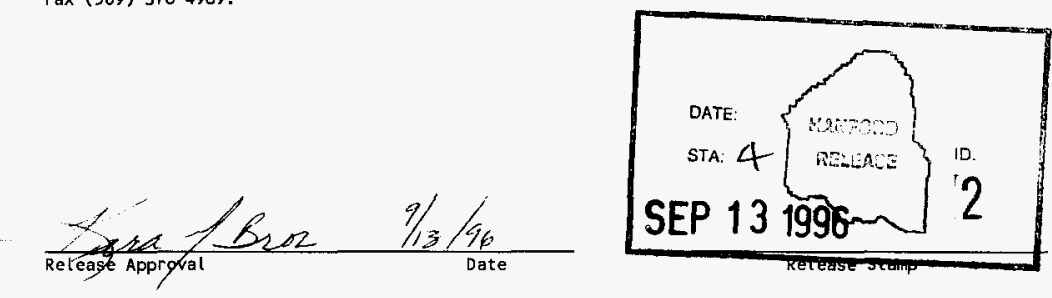

\section{Approved for Public Release}




\title{
Tank Characterization Report for Single-Shell Tank 241-S-101
}

\author{
A. A. Kruger \\ Westinghouse Hanford Company \\ B. J. Morris \\ Los Alamos Technical Associates \\ L. J. Fergestrom \\ Technical Resources International, Inc.
}

Date Published

September 1996

Prepared for the U.S. Department of Energy

Assistant Secretary for Environmental Management

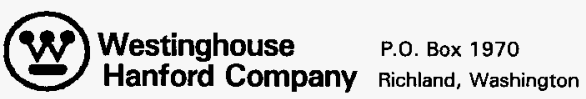

Management and Operations Contractor for the

U.S. Department of Energy under Contract DE-AC06-87RL10930

Approved for public release; distribution is unlimited. 


\section{EXECUTIVE SUMMARY}

This characterization report summarizes information on the historical uses, current status, and sampling and analysis results of waste stored in single-shell tank 241-S-101. This report supports requirements of Hanford Federal Facility Agreement and Consent Order Milestone M-44-09 (Ecology et al. 1996).

Tank 241-S-101 is located in the Hanford Site 200 West Area S Tank Farm. The tank went into service in the third quarter of 1953 , when it received high-level reduction-oxidation (REDOX) waste. The tank continued to receive REDOX waste until 1955, and did not receive waste again until 1973 . The tank received many different waste types from numerous tanks in the S, SX and U tank farms between 1973 and 1980. Throughout its service life, the tank has received the following waste types: REDOX, N Reactor, Pacific Northwest Laboratories (PNL), decontamination, cladding, evaporator bottoms, ion exchange, evaporator, and supernatant. The tank was removed from service in 1980, and was partially interim isolated in December 1982.

The tank has an operating capacity of $2,870 \mathrm{~kL}$ ( $758 \mathrm{kgal})$, and presently contains an estimated $1,620 \mathrm{~kL}$ (427 kgal) of waste. The total amount is estimated to be composed of $45 \mathrm{~kL}$ (12 kgal) of supernatant, $924 \mathrm{~kL}(244 \mathrm{kgal})$ of sludge, and $647 \mathrm{~kL}(171 \mathrm{kgal})$ of saltcake. 
Table ES-1. Description and Status of Tank 241-S-101.

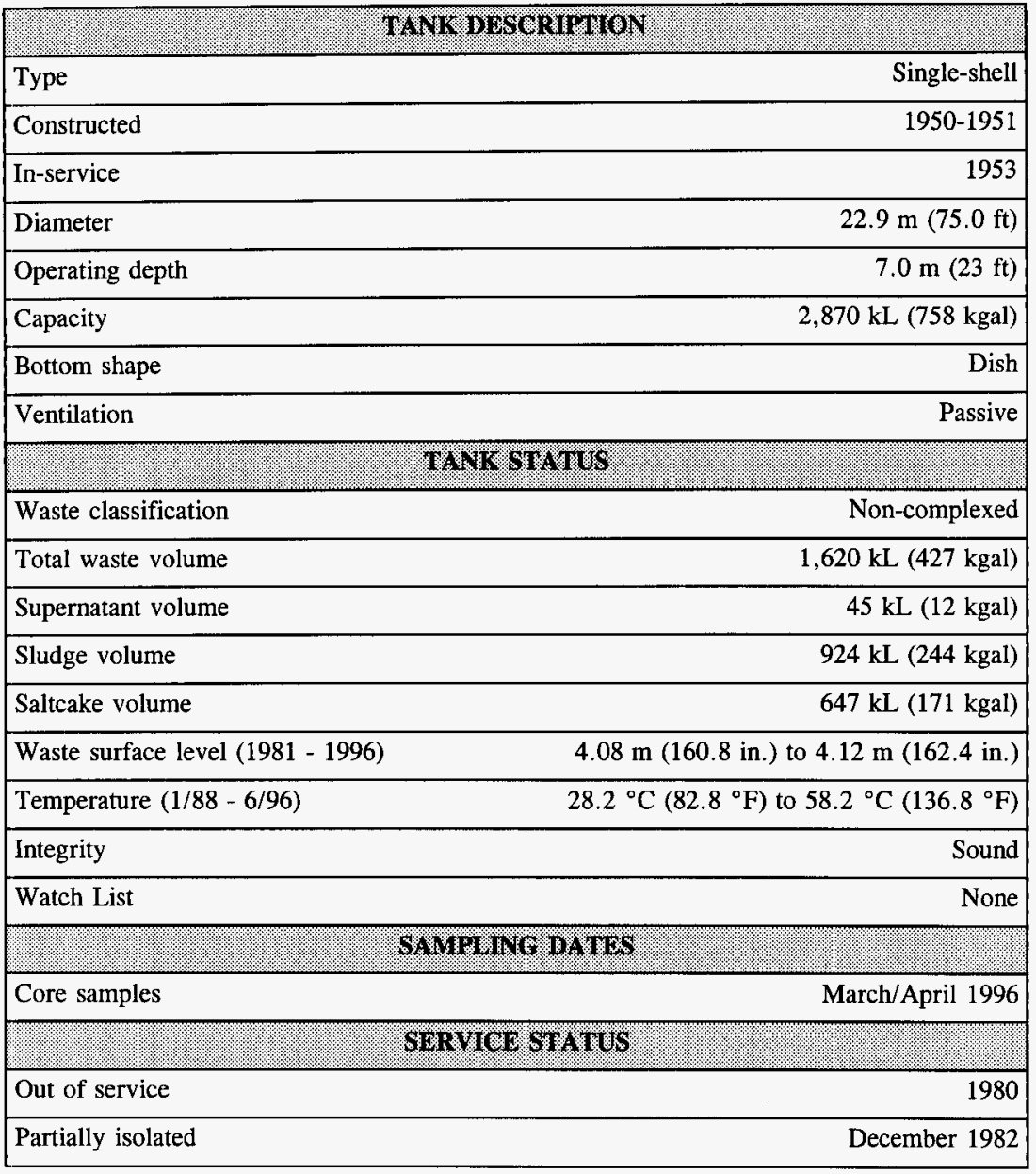


Figure ES-1. Profile of Tank 241-S-101.
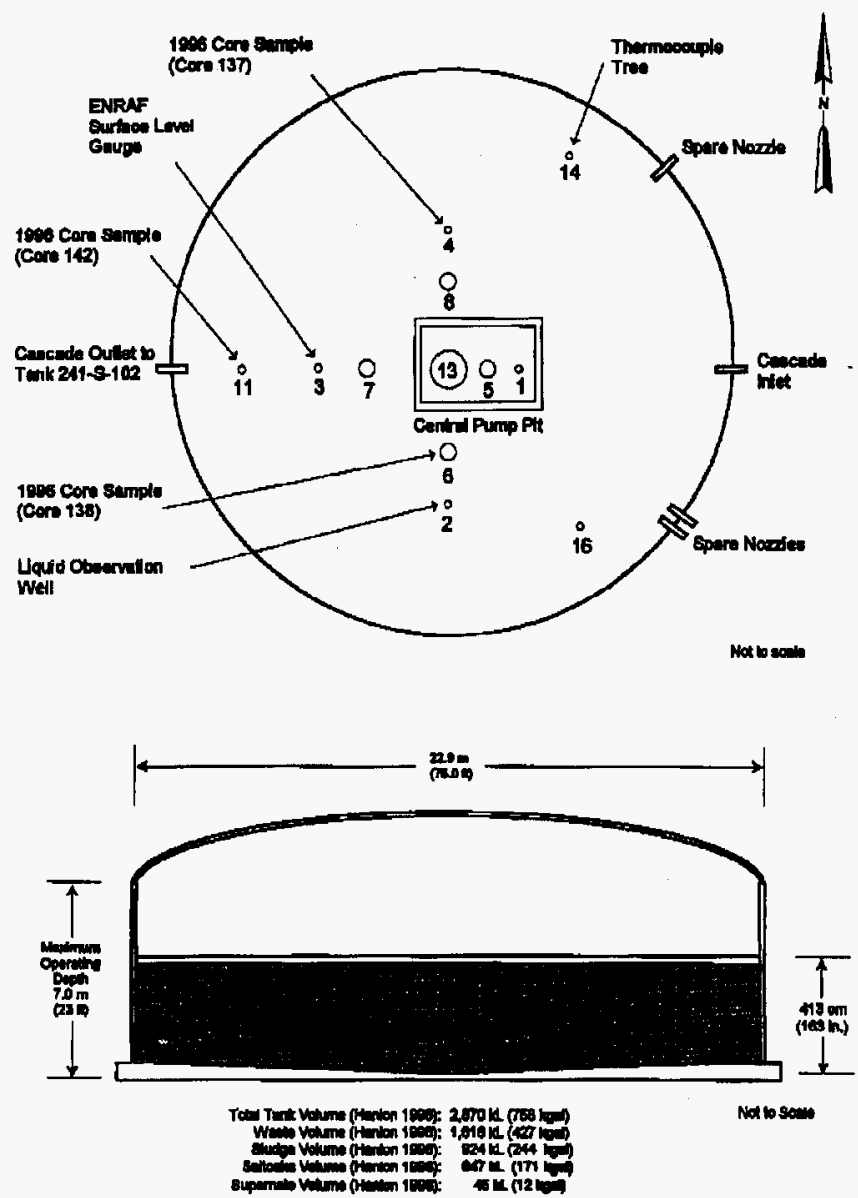
Tank 241-S-101 was sampled in March/April 1996 to satisfy the requirements of Tank Safety Screening Data Quality Objective (Dukelow et al. 1995), Historical Model Evaluation Data Requirements (Simpson and McCain 1995), and Strategy for Sampling Hanford Site Tank Wastes for Development of Disposal Technology (Kupfer et al. 1995). This sampling effort involved taking push-mode core samples of the tank waste from three different risers. The sampling and analyses were performed in accordance with Tank 241-S-101 Push Mode Core Sampling and Analysis Plan (Kruger 1996). All analyses on samples from core 138 and core 142 were performed at the Westinghouse Hanford Company (WHC) 222-S Laboratory. Samples from core 137 were composited and a subsample sent to the Pretreatment Program to fulfill the sampling and analysis plan (SAP) requirements.

The purpose of the safety screening data quality objective (DQO) is to identify any unknown safety issues and to evaluate the tank for placement on or removal from a Watch List. To accomplish this, the safety screening DQO requires a measurement of the total fuel content/energetics of the waste by differential scanning calorimetry (DSC), weight percent water by thermogravimetric analysis (TGA), bulk density of solids or specific gravity (SpG) of liquids, and total alpha activity by alpha proportional counting. The safety screening DQO also requires a determination of the flammability of the tank headspace gases. To satisfy this requirement, the flammability of the tank headspace was measured as a percentage of the lower flammability limit (LFL) using a combustible gas meter. The historical DQO required the analysis of metals by inductively coupled plasma spectroscopy 
(ICP), anions by ion chromatography (IC), total organic carbon (TOC), and selected radionuclides. The SAP also required analyses for lithium and bromide to check for contamination of the samples by the wash water used during sampling operations.

The historical DQO, through selective tank sampling, attempts to evaluate the waste composition predictions made by the Hanford Defined Waste (HDW) model, the Tank Layer Model (TLM), and the Historical Tank Content Estimate (HTCE). No specific single waste type could be isolated from tank 241-S-101 due to the spatially complex nature of the tank waste (Simpson and McCain 1995). Composite samples were formed from all segments in the core sample for each riser, and the analytical results were compared to the HTCE predictions. Comparison indicated that the measured values were at least one-tenth of the expected values, meeting the DQO requirements.

All analyses performed on the waste in tank 241-S-101 exhibited results well within the limits imposed by the safety screening DQO. The safety screening decision threshold for total alpha activity is $1 \mathrm{~g} / \mathrm{L}$, which normalizes to $34.2 \mu \mathrm{Ci} / \mathrm{g}$ for the solids using the highest density of $1.80 \mathrm{~g} / \mathrm{mL}$, and $61.5 \mu \mathrm{Ci} / \mathrm{mL}$ for the liquids. The calculated overall mean for the solids portion of the tank was $0.358 \mu \mathrm{Ci} / \mathrm{g}$, while the overall mean for the liquid portion was $<0.00810 \mu \mathrm{Ci} / \mathrm{mL}$. All results were below the decision threshold, with the largest of the upper limit one-sided 95 percent confidence interval on the mean being $2.00 \mu \mathrm{Ci} / \mathrm{g}$. The safety screening DQO has established a decision threshold of an enthalpy change of $-480 \mathrm{~J} / \mathrm{g}$ (dry weight basis) for the DSC analyses; for comparison to this limit, all analytical results were first converted to a dry weight basis. All exothermic results were below the decision 
below the decision threshold, with the largest upper limit one-sided 95 percent confidence interval on the mean upper limit being $-226 \mathrm{~J} / \mathrm{g}$. The weight percent water results were 40.2 percent for the solids and 53.1 percent for the liquids, as measured by TGA.

Core composites were analyzed for TOC to satisfy the historical DQO. Results were compared with the safety screening decision threshold of $30,000 \mu \mathrm{g} \mathrm{C} / \mathrm{g}$ (dry weight basis) for information purposes. The overall mean TOC result for the core composites was 3,390 $\mu \mathrm{g} \mathrm{C} / \mathrm{g}$ (wet), while the highest upper limit one-sided 95 percent confidence interval on the mean upper limit was $5,720 \mu \mathrm{g} \mathrm{C} / \mathrm{g}$ (wet).

The flammability of the gas in the tank headspace is an additional safety screening DQO consideration. The notification limit for flammable gas concentration is 25 percent of the LFL. The highest combustible gas meter reading was 7 percent of the LFL. Additional measurements were taken for ammonia $(600 \mathrm{ppm})$, oxygen (20.8 percent), and total organic vapor (31 ppm).

Another factor in assessing tank safety is the heat generation and temperature of the waste. Heat is generated in the tanks from radioactive decay. The total tank heat load estimate from radionuclide data was $5,970 \mathrm{~W}(20,400 \mathrm{Btu} / \mathrm{hr})$. The HTCE prediction was $5,010 \mathrm{~W}$ $(17,100 \mathrm{Btu} / \mathrm{hr}$ ) (Agnew et al. 1996a), while an estimate based on the tank headspace temperature was 4,020 W $(13,700 \mathrm{Btu} / \mathrm{hr})$ (Kummerer 1994). The estimates are in reasonable agreement and are well below the $11,700 \mathrm{~W}(40,000 \mathrm{Btu} / \mathrm{hr})$ operating 
specification limit for single-shell tanks (Bergmann 1991). Because an upper temperature limit has been exhibited (Section 2.4.3), it may be concluded that any heat generated from radioactive sources throughout the year is dissipated.

Based upon the decision criteria of the safety screening DQO, this tank may be categorized as "safe." The waste in tank 241-S-101 may continue to be safely stored in the tank without special action. In addition, there were no unexpected findings that could affect the ability to retrieve and dispose of the waste safely.

Table ES-2 presents the results for major analytes and analytes of concern. 
Table ES-2. Major Analytes and Analytes of Concern. (2 sheets)

\begin{tabular}{|c|c|c|c|c|c|}
\hline (inalte & $\begin{array}{l}\text { Meari Solid } \\
\text { Comentration }\end{array}$ & $\begin{array}{l}\text { Solid } \\
\text { Rsi } \\
\text { (Near) }\end{array}$ & $\begin{array}{l}\text { Mean } \\
\text { Suppenatant } \\
\text { Concentration }\end{array}$ & $\begin{array}{l}\text { Sumperingtini } \\
\text { Rob Nean) }\end{array}$ & $\begin{array}{l}\text { Total } \\
\text { Irventory }\end{array}$ \\
\hline METHS & .968 & $\%$ & rginil. & 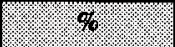 & kis \\
\hline Aluminum & 80,500 & 14.7 & 24,500 & 2.9 & $2.10 \mathrm{E}+05$ \\
\hline Chromium & 7,250 & 20.5 & 813 & 1.3 & 18,800 \\
\hline Iron & 1,360 & 8.2 & $<20.1$ & N/A & 3,530 \\
\hline Manganese & 1,540 & 17.8 & $<4.01$ & N/A & 3,990 \\
\hline Phosphorous & $1,400^{1}$ & 24.5 & 1,260 & 7.7 & 3,690 \\
\hline Potassium & $926^{1}$ & 10.2 & 2,360 & 6.5 & 2,510 \\
\hline Sodium & $1.49 \mathrm{E}+05$ & 4.8 & $2.15 \mathrm{E}+05$ & 0.7 & $3.96 \mathrm{E}+05$ \\
\hline Sulfur & $1,960^{1}$ & 50.9 & 1,860 & 5.1 & 5,160 \\
\hline Uranium & $4,680^{1}$ & 23.9 & $<200$ & N/A & 12,100 \\
\hline ANTONS: & 496 & 1.8 & ugrint. & : & 189. \\
\hline Chloride & 3,460 & 9.5 & 7,450 & 1.3 & 9,310 \\
\hline Nitrate & $1.62 \mathrm{E}+05$ & 25.1 & $1.81 \mathrm{E}+05$ & 1.7 & $4.28 \mathrm{E}+05$ \\
\hline Nitrite & 49,200 & 8.4 & 94,000 & 1.0 & $1.32 \mathrm{E}+05$ \\
\hline Oxalate & 5,700 & 44.7 & $<858$ & N/A & 14,800 \\
\hline Phosphate & 3,680 & 56.3 & 3,600 & 6.1 & 9,700 \\
\hline Sulfate & 7,250 & 46.1 & 5,650 & 4.6 & 19,100 \\
\hline $\begin{array}{l}\text { RADIO } \\
\text { Nuctions }\end{array}$ & . 418 & 76 & iginu & 1.9 .9 & a \\
\hline Total alpha & 0.358 & 24.0 & $<0.00810$ & N/A & 949 \\
\hline${ }^{137} \mathrm{Cs}$ & 131 & 10.3 & --- & --- & $3.40 \mathrm{E}+05$ \\
\hline${ }^{90} \mathrm{Sr}$ & $252^{2}$ & 19.6 & --- & --- & $6.53 \mathrm{E}+05$ \\
\hline
\end{tabular}


Table ES-2. Major Analytes and Analytes of Concern. (2 sheets)

\begin{tabular}{|c|c|c|c|c|c|}
\hline . & 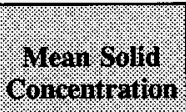 & 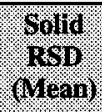 & 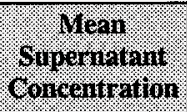 & 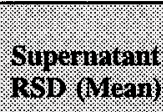 & . \\
\hline $\operatorname{loman}_{1}$ & $48 \times 18$ & 10 & $48 \%$ \%14 & \% & 68 \\
\hline $\begin{array}{l}\text { Total inorganic } \\
\text { carbon }\end{array}$ & $3,760^{2}$ & 58.3 & -- & --- & 5,160 \\
\hline $\begin{array}{l}\text { Total organic } \\
\text { carbon }\end{array}$ & $1,990^{2}$ & 57.3 & --- & --- & 9,750 \\
\hline 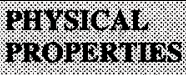 & solid Miram & \%. & Giugriatant & 6 & 188 \\
\hline $\begin{array}{l}\text { Weight percent } \\
\text { water }\end{array}$ & $40.2 \%$ & 3.5 & $53.1 \%$ & 1.0 & $1.07 \mathrm{E}+06$ \\
\hline Density & $1.65 \mathrm{~g} / \mathrm{mL}$ & 2.0 & $1.36 \mathrm{~g} / \mathrm{mL}$ & 0.7 & --- \\
\hline
\end{tabular}

Note:

$$
\begin{array}{lll}
\text { N/A } & = & \text { not applicable } \\
\text { RSD } & = & \text { relative standard deviation } \\
--- & = & \text { not analyzed }
\end{array}
$$

${ }^{\mathrm{I}}$ The results are from samples prepared by acid digestion, while all other metal results are from the fusion digestion data. Any one particular method was not chosen exclusively, this, so as to provide the most conservative estimate.

${ }^{2}$ Mean is reported from core composite results. 
WHC-SD-WM-ER-613 Rev. 0

This page intentionally left blank. 


\section{CONTENTS}

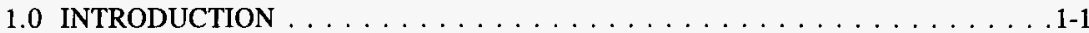

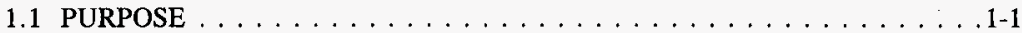

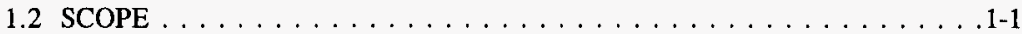

2.0 HISTORICAL TANK INFORMATION $\ldots \ldots \ldots \ldots \ldots \ldots \ldots \ldots \ldots \ldots$

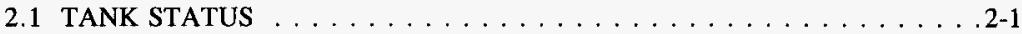

2.2 TANK DESIGN AND BACKGROUND $\ldots \ldots \ldots \ldots \ldots \ldots \ldots \ldots .2-2$

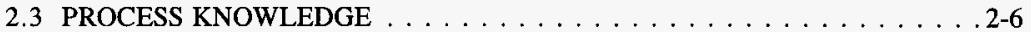

2.3.1 Waste Transfer History . . . . . . . . . . . . . . . . 2-6

2.3.2 Historical Estimation of Tank Contents . . . . . . . . . 2-8

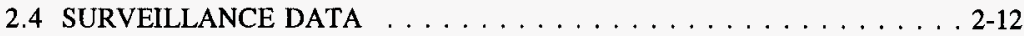

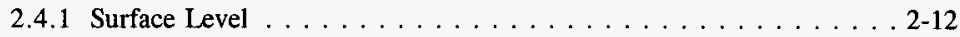

2.4.2 Internal Tank Temperatures . . . . . . . . . . . . 2-12

2.4.3 Tank 241-S-101 Photographs . . . . . . . . . . . . 2-12

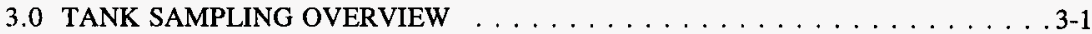

3.1 DESCRIPTION OF SAMPLING EVENT $\ldots \ldots \ldots \ldots \ldots \ldots \ldots \ldots$. $\ldots \ldots$

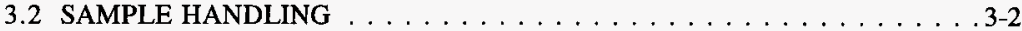

3.3 SAMPLE ANALYSIS $\ldots \ldots \ldots \ldots \ldots \ldots \ldots \ldots \ldots \ldots . \ldots \ldots$

3.4 DESCRIPTION OF EARLIER SAMPLING EVENTS . . . . . . . . . . 3-6

3.4.1 Sample Handling and Analysis (1971) . . . . . . . . . . . . 3-6

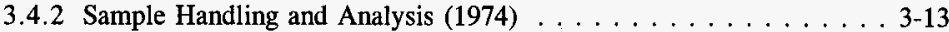

3.4.3 Sample Handling and Analysis (1975) . . . . . . . . . . . 3-13

3.4.4 Sample Handling and Analysis (1991) . . . . . . . . . 3-13

4.0 ANALYTICAL RESULTS $\ldots \ldots \ldots \ldots \ldots \ldots \ldots \ldots \ldots$. . . . . . . . . . . . .

4.1 DATA PRESENTATION $\ldots \ldots \ldots \ldots \ldots \ldots \ldots \ldots \ldots . \ldots \ldots$. 1

4.1.1 Chemical Data Summary . . . . . . . . . . . . . . . 4-1

4.1.2 Physical Data Summary . . . . . . . . . . . . . . . . . . . 4-7

4.1.3 Tank Headspace Flammability . . . . . . . . . . . . . . . . . 4-9

4.1.4 Wash Water Contamination Check . . . . . . . . . . . . . . 4-9

5.0 INTERPRETATION OF CHARACTERIZATION RESULTS $\ldots \ldots \ldots \ldots \ldots$. . . . . .

5.1 ASSESSMENT OF SAMPLING AND ANALYTICAL RESULTS $\ldots \ldots \ldots$. 5-1

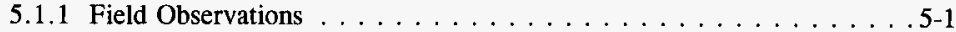

5.1 .2 Quality Control Assessment . . . . . . . . . . . . . 5-1

5.1.3 Data Consistency Checks . . . . . . . . . . . . . . . . 5-2

5.2 COMPARISON OF HISTORICAL WITH ANALYTICAL RESULTS $\ldots . .5-6$

5.3 TANK WASTE PROFILE . . . . . . . . . . . . . . . . . . . 5-7

5.3.1 Analysis of Variance Results . . . . . . . . . . . . . . . . 5-7

5.4 COMPARISON OF TRANSFER HISTORY WITH ANALYTICAL

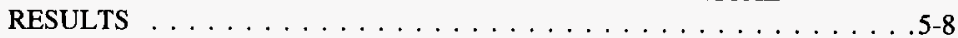




\section{CONTENT (Continued) .}

5.5 EVALUATION OF PROGRAM REQUIREMENTS $\ldots \ldots \ldots \ldots$. . . . . . . .

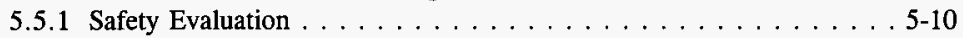

5.5.2 Historical Model Evaluation $\ldots \ldots \ldots \ldots \ldots \ldots \ldots \ldots \ldots$ 5-12

6.0 CONCLUSIONS AND RECOMMENDATIONS $\ldots \ldots \ldots \ldots \ldots \ldots$ 6-1

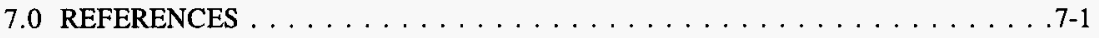

APPENDICES

A ANALYTICAL RESULTS FROM 1996 CORE SAMPLING $\ldots \ldots \ldots \ldots \ldots$. . . .

B RESULTS OF HYDROSTATIC HEAD FLUID CONTAMINATION CHECK

FOR SINGLE-SHELL TANK $241-$ S-101 . . . . . . . . . . . . . . . B

C EARLIER SAMPLING EVENTS $\ldots \ldots \ldots \ldots \ldots \ldots \ldots \ldots$ C-1 


\section{LIST OF FIGURES}

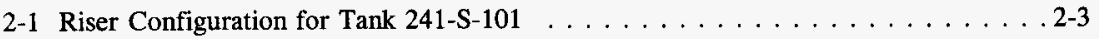

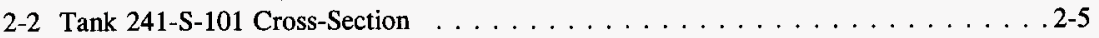

2-3 Tank Layer Model for Tank 241-S-101 . . . . . . . . . . . . . . . . . . . 2-9

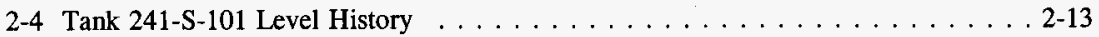

2-5 Tank 241-S-101 Weekly High Temperature Plot . . . . . . . . . . . . 2-14

\section{LIST OF TABLES}

2-1 Estimated Tank Contents . . . . . . . . . . . . . . . . . . . . . 2-1

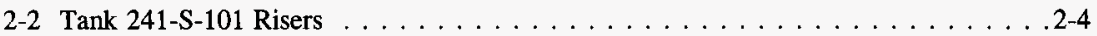

2-3 Summary of Tank $241-S-101$ Waste Input History $\ldots \ldots \ldots \ldots$. . . . . . . . .

2-4 Tank 241-S-101 Inventory Estimate . . . . . . . . . . . . . 2-10

3-1 Integrated Data Quality Objective Requirements for Tank 241-S-101 . . . . . . 3-1

3-2 Subsampling Scheme and Sample Description $\ldots \ldots \ldots \ldots \ldots \ldots$ 3-3

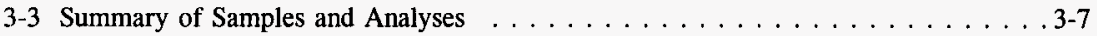

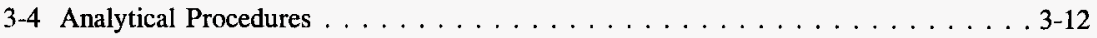

4-1 Analytical Data Presentation Tables $\ldots \ldots \ldots \ldots \ldots \ldots \ldots \ldots$. . . . . . . .

4-2 Solid and Liquid Chemical Data Summary for Tank 241-S-101 . . . . . . . . . 4-3

4-3 DSC Exothermic Results and 95 Percent Confidence Interval Upper Limits . . . . 4-8

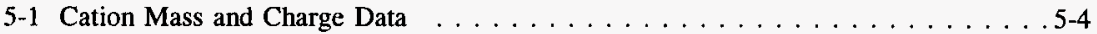

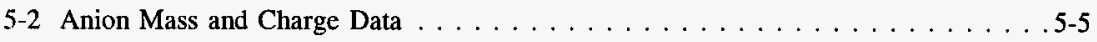


WHC-SD-WM-ER-613 Rev. 0

\section{LIST OF TABLES (Continued)}

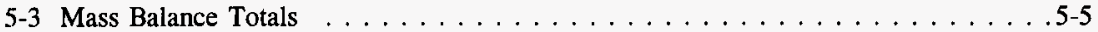

5-4 Comparison of Gross Beta Measurements and Individual Beta Emitters . . . . . . 5-6

5-5 Comparison of Data from the 1991 and 1996 Sampling Events . . . . . . . 5-6

5-6 Comparison of Historical Estimates with the 1996 Analytical Results for Tank $241-$ S-101 . . . . . . . . . . . . . . . . . . . . . . . . . . . 5-9

5-7 Decision Variables and Criteria for the Safety Screening and Historical Data Quality Objectives . . . . . . . . . . . . . . . . . . 5-10

5-8 Tank 241-S-101 Projected Heat Load . . . . . . . . . . . . . . . 5-12

5-9 Comparison of Historical Tank Content Estimates with Mean Core Composite Results from Tank $241-\mathrm{S}-101 \ldots \ldots \ldots \ldots$. . . . . . . . . . . . . . . . 


\section{LIST OF TERMS}

\begin{tabular}{ll} 
ANOVA & analysis of variance \\
$\mathrm{Btu} / \mathrm{hr}$ & British thermal units per hour \\
$\mathrm{Ci}$ & curies \\
$\mathrm{Ci} / \mathrm{L}$ & curies per liter \\
$\mathrm{cm}$ & centimeter \\
$\mathrm{CWR} 1$ & REDOX cladding waste, 1952-60 \\
$\mathrm{DBP}$ & dibutyl phosphate \\
$\mathrm{dil}$ & dilution \\
$\mathrm{DL}$ & drainable liquid \\
$\mathrm{DQO}$ & data quality objective \\
$\mathrm{DSC}$ & differential scanning calorimetry \\
$\mathrm{ft}$ & feet \\
$\mathrm{g}$ & grams \\
$\mathrm{GEA}$ & gamma energy analysis \\
$\mathrm{g} / \mathrm{L}$ & grams per liter \\
$\mathrm{g} / \mathrm{gal}$ & grams per gallon \\
$\mathrm{g} / \mathrm{mL}$ & grams per milliliter \\
$\mathrm{HDW}$ & Hanford Defined Waste \\
$\mathrm{HTCE}$ & Historical Tank Content Estimate \\
in. & inches \\
$\mathrm{IC}$ & ion chromatography \\
$\mathrm{ICP}$ & inductively coupled plasma spectroscopy \\
$\mathrm{J} / \mathrm{g}$ & joules per gram \\
$\mathrm{kg}$ & kilograms \\
$\mathrm{kgal}$ & kilogallons \\
$\mathrm{kL}$ & kiloliters \\
$\mathrm{LEL}$ & lower explosive limit \\
$\mathrm{LFL}$ & lower flammability limit \\
$\mathrm{LL}$ & liner liquid \\
$\mathrm{M}$ & moles per liter \\
$\mathrm{m}$ & meter \\
$\mathrm{mL}$ & milliliters \\
$\mathrm{mg}$ & milligram \\
$\mathrm{mm}$ & millimeter \\
$\mathrm{mR} / \mathrm{hr}$ & milliroentgens per hour \\
$\mathrm{NFPA}$ & National Fire Protection Association \\
$\mathrm{PNL}$ & Pacific Northwest Laboratories \\
& \\
\hline &
\end{tabular}




\section{LIST OF TERMS}

$\begin{array}{ll}\text { ppm } & \text { parts per million } \\ \text { QC } & \text { quality control } \\ \text { R1 } & \text { REDOX waste, 1952-57 } \\ \text { REDOX } & \text { reduction-oxidation } \\ \text { RPD } & \text { relative percent difference } \\ \text { RSD } & \text { relative standard deviation } \\ \text { RSItCk } & \text { saltcake from S and SX tank farms } \\ \text { SACS } & \text { Surveillance Analysis Computer System } \\ \text { SAP } & \text { sampling and analysis plan } \\ \text { SMMS1 } & \text { Supernatant Mixing Model S1 Saltcake, 242-S campaign, 1973-76 } \\ \text { SMMS2 } & \text { Supernatant Mixing Model S2 Saltslurry, 242-S campaign, 1977-80 } \\ \text { SpG } & \text { specific gravity } \\ \text { TGA } & \text { thermogravimetric analysis } \\ \text { TLM } & \text { Tank Layer Model } \\ \text { TIC } & \text { total inorganic carbon } \\ \text { TOC } & \text { total organic carbon } \\ \text { W } & \text { watts } \\ \text { WHC } & \text { Westinghouse Hanford Company } \\ \text { WSTRS } & \text { Waste Status and Transaction Record Summary } \\ \text { wt \% } & \text { weight percent } \\ { }^{\circ} \mathrm{C} & \text { degrees Celsius } \\ { }^{\circ} \mathrm{F} & \text { degrees Fahrenheit } \\ \Delta \mathrm{H} & \text { change in enthalpy } \\ \mu \mathrm{Ci} / \mathrm{gal} & \text { microcuries per gallon } \\ \mu \mathrm{Ci} / \mathrm{g} & \text { microcuries per gram } \\ \mu \mathrm{Ci} / \mathrm{mL} & \text { microcuries per milliliter } \\ \mu \mathrm{eq} / \mathrm{g} & \text { microequivalents per gram } \\ \mu \mathrm{g} \mathrm{C/g} & \text { micrograms carbon per gram } \\ \mu \mathrm{g} \mathrm{C} / \mathrm{mL} & \text { micrograms carbon per milliliter } \\ \mu \mathrm{g} / \mathrm{g} & \text { micrograms per gram } \\ \mu \mathrm{g} / \mathrm{mL} & \text { micrograms per milliliter } \\ & \end{array}$




\subsection{INTRODUCTION}

This tank characterization report presents an overview of single-shell tank 241-S-101 and its waste contents. It provides estimated concentrations and inventories for the waste constituents based on the latest sampling and analysis activities, in combination with background tank information. Tank 241-S-101 was core sampled in March and April 1996 in accordance with Tank Safety Screening Data Quality Objective (Dukelow et al. 1995), Historical Model Evaluation Data Requirements (Simpson and McCain 1995), and Strategy for Sampling Hanford Site Tank Wastes for Development of Disposal Technology (Kupfer et al. 1995). The requirements set forth in these documents are integrated in the sampling and analysis plan (SAP) (Kruger 1996).

Tank 241-S-101 is out of service, as are all single-shell tanks, is categorized as sound, and has been partially interim isolated. The concentration and inventory values reported in this document reflect the best composition estimates of the waste based on the available analytical data and historical models. This report supports the requirements of Hanford Federal Facility Agreement and Consent Order Milestone M-44-09 (Ecology et al. 1996).

\subsection{PURPOSE}

The purpose of this report is to summarize the information about the use and contents of tank 241-S-101. When possible, this information will be used to assess issues associated with safety, operational, environmental, and process development activities. This report also serves as a reference point for more detailed information about tank 241-S-101.

\subsection{SCOPE}

The March and April 1996 core sampling event was guided by the requirements of two data quality objectives (DQOs): the safety screening DQO (Dukelow et al. 1995) and the historical DQO (Simpson and McCain 1995). The purpose of the safety screening DQO is to identify any unknown safety issues and to evaluate the tank for placement on or removal from a Watch List. The historical DQO, through selective tank sampling, attempts to evaluate the waste composition predictions made by the Hanford Defined Waste (HDW) model, the Tank Layer Model (TLM), and the Historical Tank Content Estimate (HTCE). A core composite sample was sent to the Pretreatment Program to fulfill the requirements in Kupfer et al. (1995) and the SAP. 
All analyses were performed on the core samples as directed in the SAP (Kruger 1996). These analyses were: differential scanning calorimetry (DSC) to evaluate fuel level and energetics; thermogravimetric analysis (TGA) to determine moisture content; total alpha activity analysis to evaluate criticality potential; bulk density/specific gravity; metals by inductively coupled plasma (ICP); anions by IC; total organic carbon (TOC) by hot persulfate oxidation; gamma energy analysis for ${ }^{137} \mathrm{Cs}$; total beta and ${ }^{89 / 90} \mathrm{Sr}$ by beta counting; and total uranium by laser phosphorescence. Combustible gas meter readings of the tank headspace vapors were also taken, as required by the safety screening DQO, to address flammability concerns. 


\subsection{HISTORICAL TANK INFORMATION}

This section describes tank 241-S-101 based on historical information. The first part details the current condition of the tank. The next part contains discussions of the tank's design, transfer history, and process sources that contributed to the tank waste, including an estimate of the current contents based on the process history. Events that may be related to tank safety issues, such as potentially hazardous tank contents or off-normal operating temperatures, are included. The final part summarizes available surveillance data for the tank. Solid and liquid level data are used to determine tank integrity (leaks) and to provide clues to internal activity in the solid layers of the tank. Temperature data are provided to evaluate the heat-generating characteristics of the waste.

\subsection{TANK STATUS}

As of May 1996, tank 241-S-101 contained an estimated 1,620 kL (427 kgal) of waste classified as non-complexed (Hanlon 1996). Liquid waste volume is estimated using an ENRAF $^{1}$ surface level gauge. Solid waste volume is estimated using a sludge measurement device and a photographic evaluation. The solids volume was last updated on September 16, 1980. The amounts of various waste phases in the tank are presented in Table 2-1.

Table 2-1. Estimated Tank Contents. ${ }^{1}$

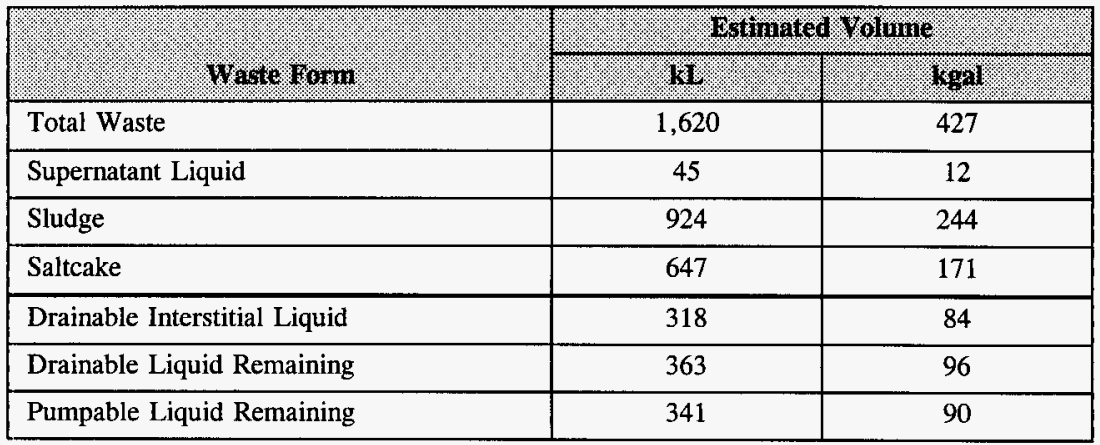

Note:

${ }^{1}$ Hanlon (1996)

'ENRAF is a registered trademark of ENRAF Corporation, Houston, Texas. 
Tank 241-S-101 is categorized as sound. The tank was removed from service in 1980 and partially interim isolated in December 1982. Tank $241-\mathrm{S}-101$ is passively ventilated and is not on any Watch Lists. All monitoring systems were in compliance with documented standards as of April 30, 1996 (Hanlon 1996).

\subsection{TANK DESIGN AND BACKGROUND}

The 241-S Tank Farm was constructed during 1950 and 1951 in the 200 West Area. The farm contains twelve 100 series tanks. The tanks have a capacity of $2,870 \mathrm{~kL}$ (758 kgal), a diameter of $2.3 \mathrm{~m}(75.0 \mathrm{ft}$ ), and an operating depth of $7.0 \mathrm{~m}(23 \mathrm{ft})$ (Leach and Stahl 1996). The 241-S Tank Farm was designed for waste with a maximum fluid temperature of $104^{\circ} \mathrm{C}\left(220^{\circ} \mathrm{F}\right)$ (Brevick et al. 1994). A cascade overflow line $75 \mathrm{~mm}$ ( 3 in.) in diameter connects tank $241-S-101$ as the first in a cascade series of three tanks finishing with tanks $241-\mathrm{S}-102$ and -103 . Each tank in the cascade series is set $305 \mathrm{~mm}$ (1 ft) lower in elevation from the preceding tank. The cascade overflow height is

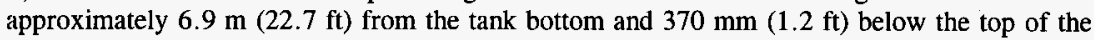
steel liner.

The tank has a dished bottom with a 1.2-m (4-ft) radius knuckle. Tank 241-S-101 was designed with a primary mild steel liner and a concrete dome with various risers. The tank is set on a reinforced concrete foundation. The tank and foundation were waterproofed by a coating of tar covered by a three-ply, asphalt-impregnated, waterproofing fabric. The waterproofing was protected by a welded-wire-reinforced cement-like mixture. One coat of primer was sprayed on all exposed interior tank surfaces. The ceiling of the tank dome was covered with six applications of a vinyl resin coating (Rutherford 1949). Lead flashing was used to protect the joint where the steel liner meets the concrete dome. Asbestos gaskets were used to seal the risers in the tank dome. The tank was covered with approximately 1.8 in $(6 \mathrm{ft})$ of overburden.

Tank 241-S-101 has 12 risers, according to the drawings and engineering change notices. The risers range in diameter from $100 \mathrm{~mm}$ (4 in.) to $1.1 \mathrm{~m} \mathrm{(42} \mathrm{in.).} \mathrm{Table} 2-2$ shows numbers, diameters, and descriptions of the risers and the inlet, overflow, and spare nozzles. A plan view that depicts the riser configuration is shown as Figure 2-1. Risers 4, 11, and $16,100 \mathrm{~mm}$ (4 in.) in diameter, and riser $6,300 \mathrm{~mm}$ (12 in.) in diameter, are available for use in sampling activities (Lipnicki 1996). A tank cross-section showing the approximate waste level along with a schematic of the tank equipment is shown in Figure 2-2. 
Figure 2-1. Riser Configuration for Tank 241-S-101.

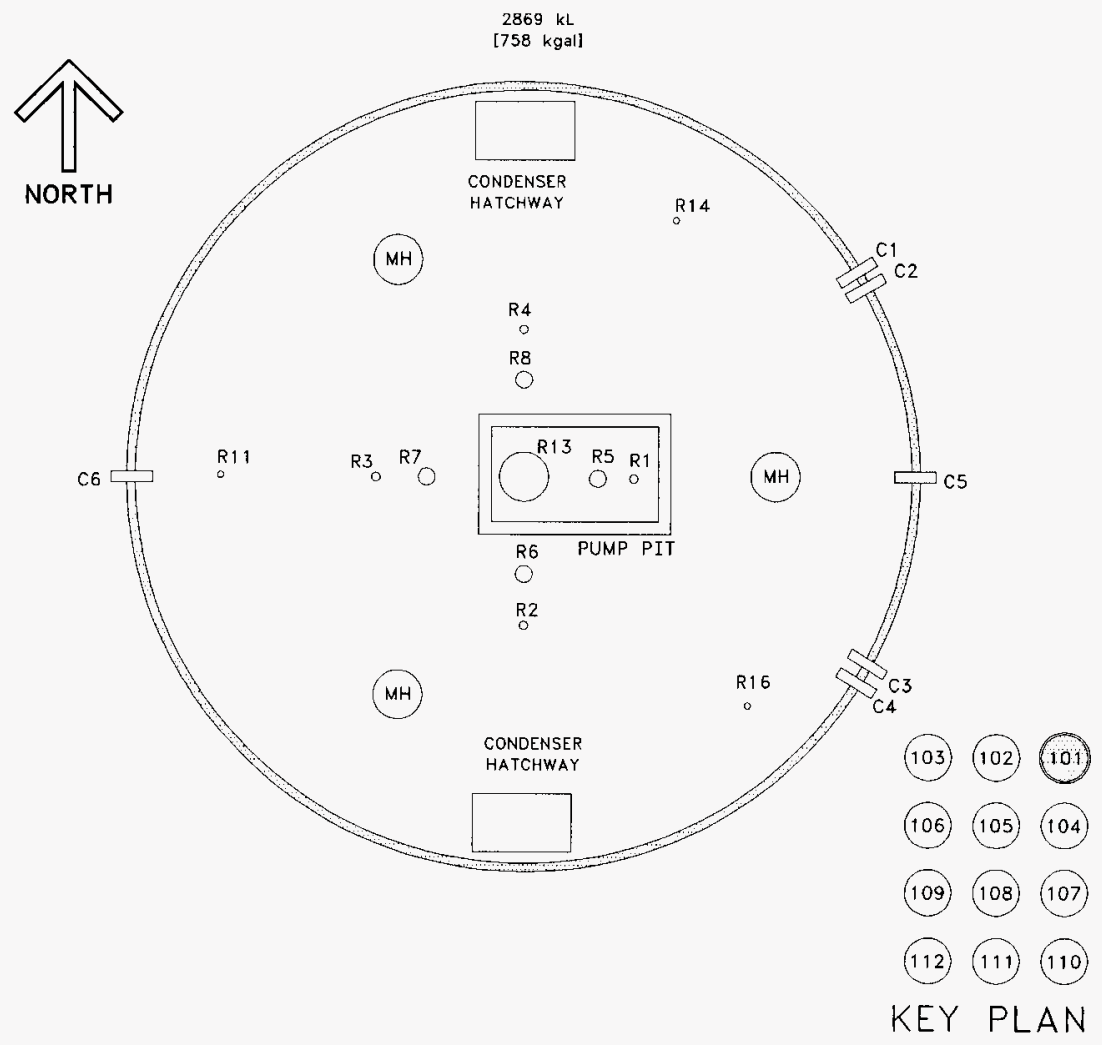


Table 2-2. Tank 241-S-101 Risers. ${ }^{1,2,3,4}$

\begin{tabular}{|c|c|c|c|}
\hline \multirow{2}{*}{ Rimber } & \multicolumn{2}{|c|}{ Dianeter. } & \multirow[b]{2}{*}{ Description and Conments } \\
\hline & $\sin$ & in. & \\
\hline 1 & 10 & 4 & Connection nozzle, pump pit drain \\
\hline 2 & 10 & 4 & Liquid observation well, benchmark \\
\hline 3 & 10 & 4 & ENRAF $^{T M}$ \\
\hline 4 & 10 & 4 & Flange, spare \\
\hline 5 & 30 & 12 & Saltwell screen and pump \\
\hline 6 & 30 & 12 & Observation port \\
\hline 7 & 30 & 12 & Blank installed, unused \\
\hline 8 & 30 & 12 & Plug \\
\hline 11 & 10 & 4 & Sludge measurement port \\
\hline 13 & 110 & 42 & Slurry distributor \\
\hline 14 & 10 & 4 & Thermocouple tree \\
\hline 16 & 10 & 4 & Breather filter, G-1 housing, benchmark \\
\hline Nor, 18 & \multicolumn{2}{|c|}{ Dlaninerer. } & \\
\hline Number & cin & in. & Description and Comments. \\
\hline $\mathrm{C} 1$ & 8 & 3 & Spare \\
\hline $\mathrm{C} 2$ & 8 & 3 & Spare \\
\hline $\mathrm{C} 3$ & 8 & 3 & Spare \\
\hline $\mathrm{C} 4$ & 8 & 3 & Spare \\
\hline C5 & 8 & 3 & Overflow inlet \\
\hline C6 & 8 & 3 & Overflow outlet \\
\hline
\end{tabular}

Notes:

'Alstad (1993)

${ }^{2}$ Tran (1993)

${ }^{3}$ Vitro Engineering Corporation (1980)

${ }^{4}$ ARHCO (1975) 
Figure 2-2. Tank 241-S-101 Cross-Section.

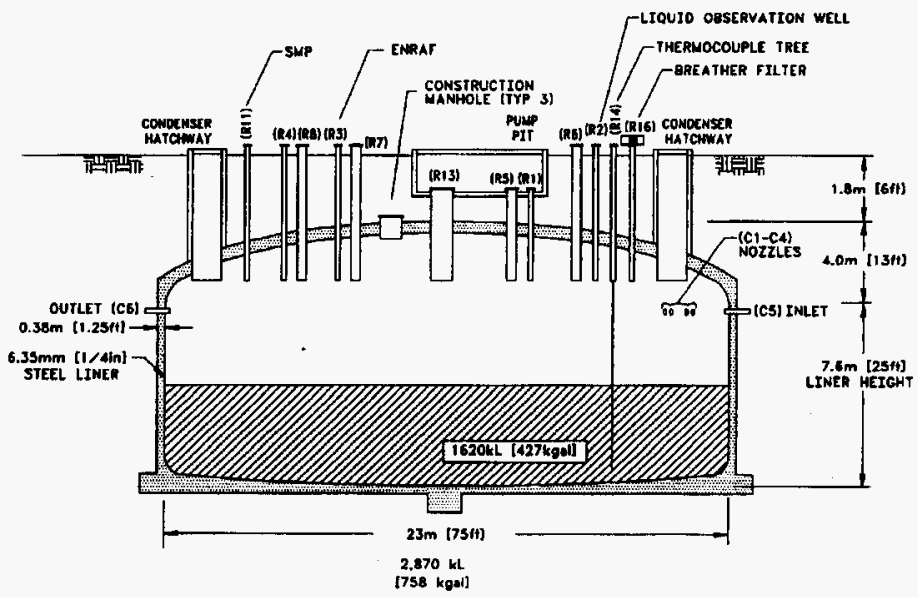




\subsection{PROCESS KNOWLEDGE}

Section 2.3.1 includes all major transfers involving tank 241-S-101 and Table 2-3 presents the history of the major transfers that involved tank 241-S-101 receiving waste. Section 2.3.2 contains an estimate of the tank's contents based on historical data.

\subsubsection{Waste Transfer History}

Tank 241-S-101 first received high-level reduction-oxidation (REDOX) waste in the third and fourth quarters of 1953 (Agnew et al. 1996b). During this time, waste cascaded to tank 241S-102 and was sent to catch tank S-003. In 1954, the tank received high level REDOX waste and REDOX cladding waste. During that year, waste cascaded to tank 241-S-102 and was sent to tank S-003. In the third quarter of 1955, the tank received REDOX cladding waste and flush water. Again, waste cascaded to tank 241-S-102 and was sent to tank S-003 during this year. During 1956, waste was sent to catch tank S-003.

Flush water was sent to the tank during the first quarter of 1958 . The waste selfconcentrated, causing a slow reduction in volume from 1958 until 1973. Supernatant waste was received from tank $241-\mathrm{U}-107$ and -108 during the fourth quarter of 1973 . The waste in these tanks at the time of transfer included $\mathrm{N}$ Reactor waste, PNL waste, decontamination waste, cladding waste, and evaporator feed/bottoms. Waste was sent from tank 241-S-101 to tank 241-S-102 during this time.

During 1974, the tank received supernatant waste from tanks $241-S-102,-105,-107,-110$, and -111 ; tank 241-SX-101; and tanks $241-\mathrm{U}-103$ and -107 , as well as flush water. The waste in these tanks at the time of transfer included REDOX waste, evaporator waste, $\mathrm{N}$ reactor waste, and PNL waste. Waste was sent to tanks 241-S-102 and -107 during that year.

During 1975, the tank again received waste from tanks 241-S-105 and -107 and tank 241-S-102. Waste was sent to tank 241-S-102 during that year. During the first quarter of 1976, tank 241-S-101 received supernatant waste from tank 241-SX-105. Supernatant waste was sent from 241-S-101 to tank 241-SY-102 in the third quarter of 1978 and the first quarter of 1979 and to tanks 241-S-102 and -103 during the second quarter of 1979 . Tank 241-S-101 received waste from tank 241-S-107 during the fourth quarter of 1979.

In 1980 , the tank received waste from tanks $241-S-103$ and $241-S X-104$ and waste was sent to tanks 241-S-107 and 241-SY-102.

Tank 241-S-101 was declared inactive in 1980. Presently, the waste in tank 241-S-101 is classified as non-complexed (Hanlon 1996). 
Table 2-3. Summary of Tank 241-S-101 Waste Input History. ${ }^{1,2}$

\begin{tabular}{|c|c|c|c|c|}
\hline \multirow[b]{2}{*}{ Transfer Source } & \multirow[b]{2}{*}{ Waste Type Recired } & \multirow[b]{2}{*}{ Thine: } & \multicolumn{2}{|c|}{ Estinated Volune } \\
\hline & & & 14: & kgai \\
\hline S Plant (REDOX) & $\begin{array}{l}\text { High-level REDOX } \\
\text { waste }\end{array}$ & $1953-1954$ & 7,882 & 2,082 \\
\hline S Plant (REDOX) & $\begin{array}{l}\text { REDOX cladding } \\
\text { waste }\end{array}$ & $1954-1955$ & 1,321 & 349 \\
\hline Miscellaneous & Flush water & 1955,1958 & 155 & 41 \\
\hline 241-U-107, 241-U-108 & $\begin{array}{l}\text { N Reactor waste, } \\
\text { decontamination } \\
\text { waste, PNL waste, } \\
\text { cladding waste, } \\
\text { evaporator } \\
\text { feed/bottoms }\end{array}$ & 1973 & 2,302 & 608 \\
\hline $\begin{array}{l}\text { 241-S-102, 241-S-105, } \\
241-S-107,241-S-110, \\
241-S-111, \\
\text { 241-SX-101, } \\
\text { 241-U-103, 241-U-107 }\end{array}$ & $\begin{array}{l}\text { High-level REDOX } \\
\text { waste, } \mathrm{N} \text { Reactor } \\
\text { waste, PNL waste, } \\
\text { decontamination } \\
\text { waste, evaporator } \\
\text { bottoms }\end{array}$ & 1974 & 23,890 & 6,311 \\
\hline Miscellaneous & Flush water & 1974 & 424 & 112 \\
\hline $\begin{array}{l}\text { 241-S-102, 241-S-105, } \\
241-S-107\end{array}$ & $\begin{array}{l}\text { High-level REDOX } \\
\text { waste, } \mathrm{N} \text { Reactor } \\
\text { waste, PNL waste, } \\
\text { decontamination } \\
\text { waste, evaporator } \\
\text { bottoms }\end{array}$ & 1975 & 2,196 & 580 \\
\hline 241-SX-105 & $\begin{array}{l}\text { Supernatant from } \\
\text { evaporator bottoms }\end{array}$ & 1976 & 996 & 263 \\
\hline 241-S-103, 241-S-107 & $\begin{array}{l}\text { N Reactor waste, } \\
\text { PNL waste, } \\
\text { decontamination } \\
\text { waste, evaporator } \\
\text { bottoms }\end{array}$ & 1979 & 450 & 262 \\
\hline 241-S-103, 241-SX-104 & $\begin{array}{l}\text { Double-shell slurry } \\
\text { feed waste }\end{array}$ & 1980 & 1,711 & 452 \\
\hline
\end{tabular}

Notes:

${ }^{1}$ Agnew et al. (1996b)

${ }^{2}$ Waste volumes and types are best estimates based on historical data. 


\subsubsection{Historical Estimation of Tank Contents}

The following is an estimate of the contents for tank 241-S-101 based on historical transfer data. The estimates have not been validated and thus should be used with caution. The historical data used for the estimates are from the Waste Status and Transaction Record Summary for the Southwest Quadrant (WSTRS) (Agnew et al. 1996b), and the Hanford Tank Chemical and Radionuclide Inventories: HDW Model Rev. 3 (Agnew et al. 1996a).

Agnew et al. (1996a) contains the HDW list, the TLM, and the Supernatant Mixing Model (SMM). The WSTRS is a compilation of available waste transfer and volume status data. The HDW provides the assumed typical compositions for Hanford Site waste types. In most cases, the available data are incomplete reducing the reliability of the transfer data and the modeling results derived from it. The TLM takes the WSTRS data, models the waste deposition processes and, using additional data from the HDW (which may introduce more error), generates an estimate of the tank contents. Thus, these model predictions can only be considered estimates that require further evaluation using analytical data.

Based on the TLM, tank 241-S-101 contains five layers of waste, a top layer of $314 \mathrm{~kL}$ (83 kgal) of SMM S2 saltslurry from the 242-S campaign, 1977-80 (SMMS2) above a layer of $458 \mathrm{~kL}$ (121 kgal) of SMM S1 saltcake from the 242-S campaign, 1973-76 (SMMS1). Beneath these layers is a layer of $341 \mathrm{~kL}(90 \mathrm{kgal})$ saltcake from S and SX tank farms (RSltCk), which is above layers of $110 \mathrm{~kL}$ (29 kgal) of REDOX cladding waste, 1952-60 (CWR1) and $348 \mathrm{~kL}$ (92 kgal) of REDOX waste, 1952-57 (R1). Definitions for the TLM terminology can be found in the cited parent documents. Figure 2-3 shows a graph representing the estimated waste type and volumes for the tank layers. The R1 layer should contain large quantities of sodium, hydroxide, nitrite, aluminum, and iron; lesser amounts of chromium, calcium, and carbonate; and small quantities of nickel, nitrate, sulfate, silicate, and chloride. This layer will show moderate activity from the amounts of cesium and strontium. The layer of CWR1 should contain large quantities of sodium, aluminum, and hydroxide; lesser amounts of iron, lead, calcium, nitrite, nitrate, and carbonate; and small amounts of sulfate, silicate, and chloride. The amount of cesium and strontium is very low. The layer of RSItCk should contain large quantities of sodium, aluminum, hydroxide, nitrate, and nitrite; lesser amounts of chromium, silicate, and chloride; and small amounts of calcium, potassium, carbonate, iron, nickel, ammonia, and sulfate. This layer will show low activity from the amounts of cesium and strontium. The SMMS1 layer should contain large quantities of sodium, nitrate, nitrite, and aluminate; lesser amounts of hydroxide, fluoride, phosphate, carbonate, sulfate, glycolate, and chloride; and smaller amounts of chromium, potassium, citrate, EDTA, HEDTA, dibutyl phosphate (DBP), ammonium, butanol, and silicate. The SMMS1 layer contains small amounts of cesium and strontium resulting in low activity within the layer. The SMMS2 waste layer is similar to the SMMS1 layer but with greater amounts of HEDTA, potassium, hydroxide, and fluoride. The cesium and strontium content is also similar to the SMMS1 layer, thus a low amount of activity will be found. Table 2-4 shows an estimate of the expected waste constituents and their concentrations. 
Figure 2-3. Tank Layer Model for Tank 241-S-101.

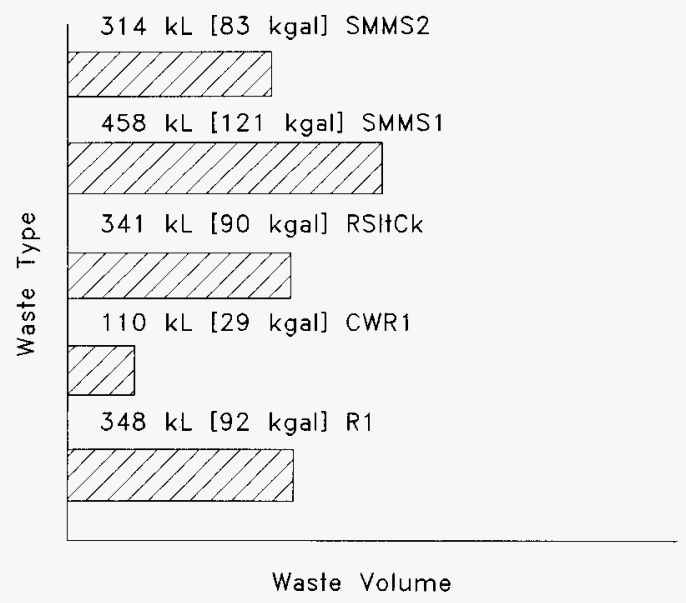


Table 2-4. Tank 241-S-101 Inventory Estimate. ${ }^{1,2}$ (2 Sheets)

\begin{tabular}{|c|c|c|c|}
\hline \multirow{2}{*}{ 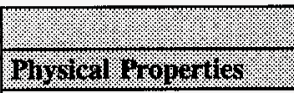 } & \multicolumn{3}{|c|}{ Total Inventory Rstimate } \\
\hline & (2) & (2: & \\
\hline Total Waste & \multicolumn{3}{|c|}{$2.41 \mathrm{E}+06 \mathrm{~kg} \quad(427 \mathrm{kgal})$} \\
\hline Heat Load & \multicolumn{3}{|c|}{$5,010 \mathrm{~W} \quad(17,100 \mathrm{Btu} / \mathrm{hr})$} \\
\hline Bulk Density & \multicolumn{3}{|c|}{$1.49 \mathrm{~g} / \mathrm{mL}$} \\
\hline Water wt $\%$ & \multicolumn{3}{|l|}{45.8} \\
\hline $\begin{array}{l}\text { Total Organic Carbon } \\
\text { wt \% Carbon (wet) }\end{array}$ & \multicolumn{3}{|l|}{0.361} \\
\hline Chemiral Constifuents: & (1) & (2) & 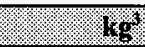 \\
\hline $\mathrm{Na}^{+}$ & 7.81 & $1.21 \mathrm{E}+05$ & $2.90 \mathrm{E}+05$ \\
\hline $\mathrm{Al}^{3+}$ & 2.61 & 47,300 & $1.14 \mathrm{E}+05$ \\
\hline $\mathrm{Fe}^{3+}($ total $\mathrm{Fe})$ & 0.236 & 8,860 & 21,300 \\
\hline $\mathrm{Cr}^{3+}$ & 0.262 & 9,130 & 22,000 \\
\hline $\mathrm{Bi}^{3+}$ & $5.12 \mathrm{E}-04$ & 71.8 & 173 \\
\hline $\mathrm{La}^{3+}$ & $1.40 \mathrm{E}-05$ & 1.31 & 3.15 \\
\hline $\mathrm{Hg}^{2+}$ & $2.81 \mathrm{E}-04$ & 37.8 & 91.1 \\
\hline $\mathrm{Zr}$ (as $\left.\mathrm{ZrO}(\mathrm{OH})_{2}\right)$ & $3.53 \mathrm{E}-04$ & 21.6 & 52.0 \\
\hline $\mathrm{Pb}^{2+}$ & 0.00844 & 1,170 & 2,830 \\
\hline $\mathrm{Ni}^{2+}$ & 0.0169 & 665 & 1,600 \\
\hline $\mathrm{Sr}^{2+}$ & 4.67E-06 & 0.275 & 0.662 \\
\hline $\mathrm{Mn}^{4+}$ & 0.00168 & 61.9 & 149 \\
\hline $\mathrm{Ca}^{2+}$ & 0.0850 & 2,290 & 5,500 \\
\hline $\mathrm{K}^{+}$ & 0.0304 & 797 & 1,920 \\
\hline $\mathrm{OH}^{-}$ & 11.1 & $1.27 \mathrm{E}+05$ & $3.05 \mathrm{E}+05$ \\
\hline $\mathrm{NO}_{3}^{-}$ & 3.31 & $1.38 \mathrm{E}+05$ & $3.32 \mathrm{E}+05$ \\
\hline $\mathrm{NO}_{2}^{-}$ & 1.89 & 58,300 & $1.40 \mathrm{E}+05$ \\
\hline $\mathrm{CO}_{3}{ }^{2-}$ & 0.256 & 10,300 & 24,900 \\
\hline $\mathrm{PO}_{4}{ }^{3-}$ & 0.0374 & 2,390 & 5,750 \\
\hline $\mathrm{SO}_{4}^{2-}$ & 0.115 & 7,420 & 17,900 \\
\hline $\mathrm{Si} \mathrm{(as} \mathrm{SiO}_{3}{ }^{2-}$ ) & 0.0646 & 1,220 & 2,930 \\
\hline$F^{-}$ & 0.0289 & 368 & 886 \\
\hline $\mathrm{Cl}^{-}$ & 0.120 & 2,840 & 6,850 \\
\hline citrate & 0.0129 & 1,640 & 3,940 \\
\hline
\end{tabular}


Table 2-4. Tank 241-S-101 Inventory Estimate. ${ }^{1,2}$ (2 Sheets)

\begin{tabular}{|c|c|c|c|}
\hline (1) & Tothi In & Estivante & . \\
\hline Chenical Constituents: & 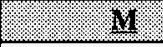 & ppris & ry \\
\hline EDTA $^{4}$ & 0.00651 & 1,260 & 3,030 \\
\hline HEDTA $^{3-}$ & 0.0120 & 2,220 & 5,330 \\
\hline glycolate & 0.0391 & 1,970 & 4,740 \\
\hline acetate & 0.00313 & 124 & 298 \\
\hline oxalate & $1.20 \mathrm{E}-05$ & 0.709 & 1.71 \\
\hline DBP & 0.00844 & 1,510 & 3,630 \\
\hline butanol & 0.00844 & 420 & 1,010 \\
\hline $\mathrm{NH}_{3}$ & 0.0590 & 673 & 1,620 \\
\hline $\mathrm{Fe}(\mathrm{CN})_{6}{ }^{4}$ & 0 & 0 & 0 \\
\hline Radrologerl Constifuents. & . & $1.0 \mathrm{~V}_{\mathrm{g}}$ & 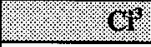 \\
\hline $\mathrm{Pu}$ & --- & 0.162 & $6.51(\mathrm{~kg})$ \\
\hline $\mathrm{U}$ & $0.0295(\underline{\mathrm{M}})$ & $4,710(\mu \mathrm{g} / \mathrm{g})$ & $11,300(\mathrm{~kg})$ \\
\hline Cs & 0.184 & 123 & $2.97 \mathrm{E}+05$ \\
\hline $\mathrm{Sr}$ & 0.332 & 223 & $5.37 \mathrm{E}+05$ \\
\hline
\end{tabular}

Notes:

${ }^{1}$ Agnew et al. (1996a)

${ }^{2}$ These estimates have not been validated and should be used with caution.

${ }^{3}$ Differences appear to exist among the inventory above and the inventories calculated from the two sets of concentrations. These differences are being evaluated. 


\subsection{SURVEILLANCE DATA}

Tank 241-S-101 surveillance consists of liquid and solid surface level measurements, and waste and headspace temperature monitoring inside the tank. These data provide the basis for determining tank integrity.

Liquid level measurement may indicate if there is a major leak from a tank. Solid surface level measurements provide an indication of physical changes and consistency of the solid layers. Tank $241-S-101$ has one liquid observation well, which is located in riser 2 and is used to measure interstitial liquid levels. Drywells are located around the perimeter of the tank to enable monitoring of increased radiation due to leakage. Five drywells have been identified for tank 241-S-101, and none are considered active.

\subsubsection{Surface Level}

The surface level of the waste has been monitored with an ENRAF ${ }^{\mathrm{TM}}$ surface level gauge through riser 3 since February 1996. The ENRAF ${ }^{\mathrm{TM}}$ surface level reading on April 30, 1996 was $4.09 \mathrm{~m}$ (160.96 in.) (WHC 1996). Surface level measurements with the Food Instrument Corporation probe have remained steady from February 1981 to January 1995, averaging $4.1 \mathrm{~m}$ (161.3 in.) with a range from $4.08 \mathrm{~m}$ (160.8 in.) to $4.12 \mathrm{~m}$ (162.4 in.). A graphical representation of the tank volume history is presented in Figure 2-4.

\subsubsection{Internal Tank Temperatures}

Tank 241-S-101 has one thermocouple tree in riser 14 with 6 thermocouples to monitor the waste temperature. Elevations are available for all thermocouples. Plots of the individual thermocouple readings can be found in the S Farm supporting document (Brevick et al. 1994).

The following temperature data were obtained from the Surveillance Analysis Computer System (SACS) database (WHC 1996). The mean temperature for the recorded period from January 4,1988 , to June 20,1996 , was $43.4^{\circ} \mathrm{C}\left(110.2^{\circ} \mathrm{F}\right)$ with a minimum of $28.2{ }^{\circ} \mathrm{C}$ $\left(82.8^{\circ} \mathrm{F}\right)$ and a maximum of $58.2^{\circ} \mathrm{C}\left(136.8^{\circ} \mathrm{F}\right)$. On June 20,1996 , the low temperature recorded was $30.8^{\circ} \mathrm{C}\left(87.4^{\circ} \mathrm{F}\right)$ on thermocouple 6 . The high temperature recording was $46.6^{\circ} \mathrm{C}\left(115.9^{\circ} \mathrm{F}\right)$ on thermocouple 3 . Thermocouple 3 is in the waste while thermocouple 6 is in the tank headspace. The graph of the weekly high temperature is provided as Figure 2-5.

\subsubsection{Tank 241-S-101 Photographs}

The March 18, 1988, photographic montage of tank 241-S-101 interior shows the waste surface in the center of the tank as a dark brown sludge, while the surface around the perimeter of the tank resembled saltcake. Recent measurements indicate that there is approximately $1,630 \mathrm{~kL}$ (430 kgal) of waste, indicating a waste depth of $4.3 \mathrm{~m} \mathrm{(14 \textrm {ft } )}$ (Brevick et al. 1994). 
Figure 2-4. Tank 241-S-101 Level History.

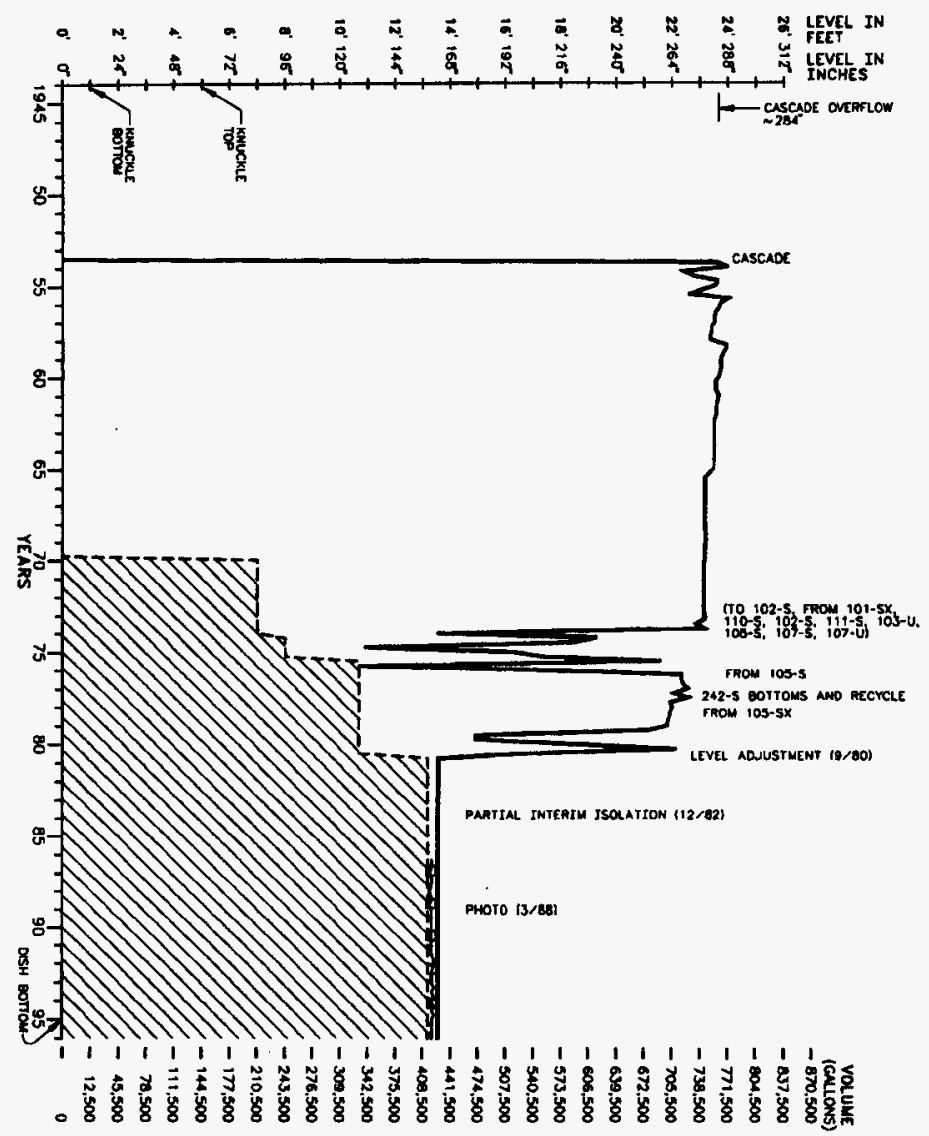


WHC-SD-WM-ER-613 Rev. 0

Figure 2-5. Tank 241-S-101 Weekly High Temperature Plot.

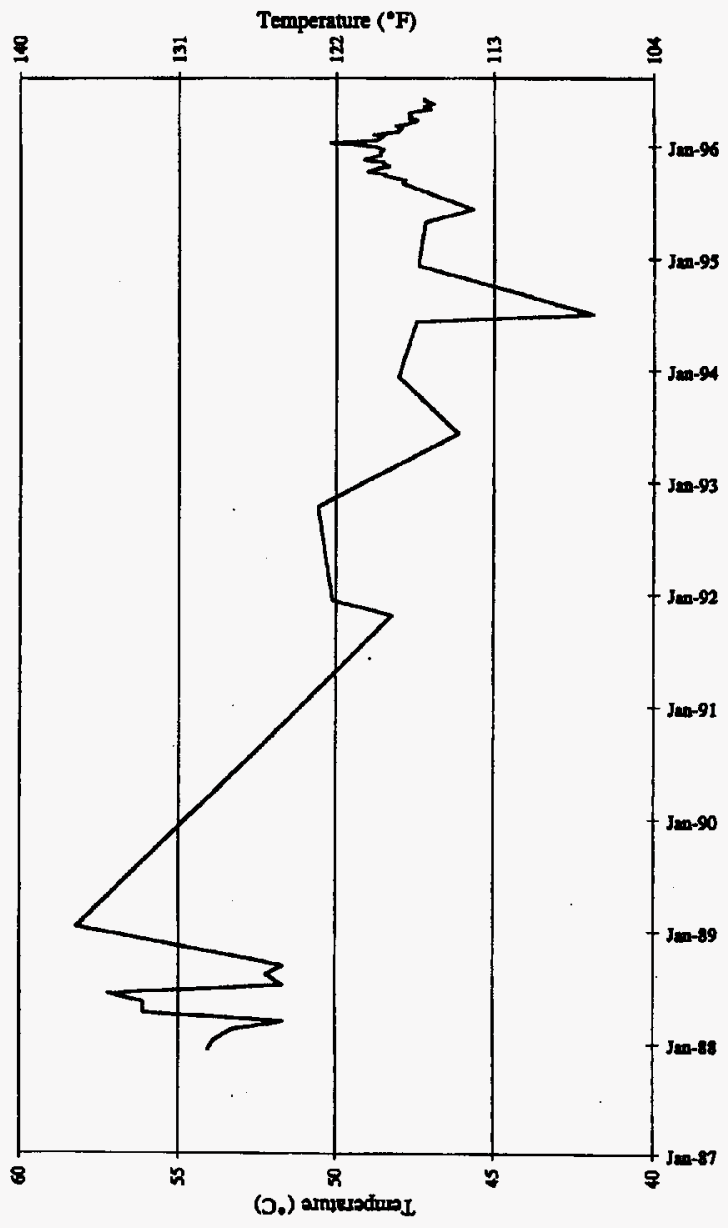




\subsection{TANK SAMPLING OVERVIEW}

This section describes the March/April 1996 sampling and analysis event for tank 241-S-101. Three push-mode core samples using a rotary core truck were taken to satisfy the requirements of the safety screening DQO (Dukelow et al. 1995), the historical model evaluation DQO (Simpson and McCain 1995), and the pretreatment program (Kupfer et al. 1996). The sampling and analyses were performed in accordance with the SAP (Kruger 1996). Further discussions of the sampling and analysis procedures can be found in the Tank Characterization Reference Guide (De Lorenzo et al. 1994).

Table 3-1 summarizes the sampling mode, applicable DQOs, and sampling and analysis requirements for the 1996 sampling event.

Table 3-1. Integrated Data Quality Objective Requirements for Tank 241-S-101. ${ }^{1}$

\begin{tabular}{|c|c|c|c|}
\hline Simpling: & applicalie: & Sarmpling Requrenents & inay, tien/ Requirencuts \\
\hline \multirow[t]{3}{*}{$\begin{array}{l}\text { Push-mode } \\
\text { core sampling } \\
\text { (March/April } \\
\text { 1996) }\end{array}$} & $\begin{array}{l}\text { Safety screening } \\
\text { (Dukelow et al. } \\
\text { 1995) }\end{array}$ & \multirow[t]{2}{*}{$\begin{array}{l}\text { Vertical profiles from two } \\
\text { widely spaced risers }\end{array}$} & $\begin{array}{l}\text { Energetics } \\
\text { - Moisture content } \\
\text { - Total alpha activity } \\
\text { - Density/SpG } \\
\text { - Flammable gas } \\
\text { - Total alpha }\end{array}$ \\
\hline & $\begin{array}{l}\text { Historical model } \\
\text { evaluation } \\
\text { (Simpson and } \\
\text { McCain 1995) }\end{array}$ & & $\begin{array}{l}\text { Energetics } \\
\text { - Moisture content } \\
\text { - }{ }^{137} \mathrm{Cs} \\
\text { Metals (Al, Cr, Na, } \\
\text { U) } \\
\text { - Anions } \\
\text { Total alpha activity } \\
\text { - Bulk density } \\
\text { - TOC } \\
\text { - Total uranium } \\
\text { - Total beta } \\
\text { - }{ }^{90} \mathrm{Sr}\end{array}$ \\
\hline & $\begin{array}{l}\text { Pretreatment } \\
\text { program (Kupfer } \\
\text { et al. 1995) }\end{array}$ & $\begin{array}{l}\text { Remove } 125 \mathrm{~mL} \text { of solid } \\
\text { composite for process } \\
\text { development work } \\
\text { Archive } 100 \mathrm{~mL} \text { of solid } \\
\text { and liquid composite for the } \\
\text { pretreatment program }\end{array}$ & $\mathrm{N} / \mathrm{A}$ \\
\hline
\end{tabular}

Note:

'Fritts (1996) 


\subsection{DESCRIPTION OF SAMPLING EVENT}

Three push-mode core samples (using a rotary core truck) were collected from tank 241-S-101 between March 12 and April 3, 1996. Cores 137, 138, and 142 were obtained from risers 4,6 , and 11 , respectively. All samples were received and extruded at the Westinghouse Hanford Company 222-S Laboratory in accordance with the SAP (Kruger 1996). However, as directed by the tank coordinator, core 137 samples were not used for analyses at the 222-S Laboratory. This decision was based on difficulties with the sampling efforts that would have made the vertical profile of the tank contents much more difficult. The material was composited and a subsample was sent to the Pretreatment Program to fulfil the SAP requirements (Kruger 1996).

In addition, the tank headspace vapors were measured for flammability (not concentration) as required by the safety screening DQO. Results for total organic vapor, oxygen, ammonia, and the lower flammability limit (LFL) of the flammable gases were obtained.

\subsection{SAMPLE HANDLING}

Cores 137,138 and 142 were received by the Westinghouse Hanford Company 222-S Laboratory between March 13 and April 23, 1996. Each sample was extruded between March 18 and April 29, 1996, and analyzed in accordance with the SAP (Kruger 1996).

Core 138 contained drainable liquid (DL) and liner liquid (LL). Several segments in cores 138 and 142 contained no solids or liquids. The remaining segments of the three cores contained solids that resembled sludge and sludge-slurry of slightly different colors. Sample recovery was variable, depending on the particular segment. No separable organic layer was observed in any of the segments. One field blank was delivered to the 222-S Laboratory with core 138. All three cores were subsampled at the whole-segment or half-segment level, depending on the amount of material recovered and the appearance of the extruded segments. Core composites were formed from cores 138 and 142 in accordance with the historical DQO. Table 3-2 presents the subsampling scheme, the amount of sample recovered, the drill string dose rates, and a visual description of the samples. 
Table 3-2. Subsampling Scheme and Sample Description ${ }^{1}$. (3 sheets)

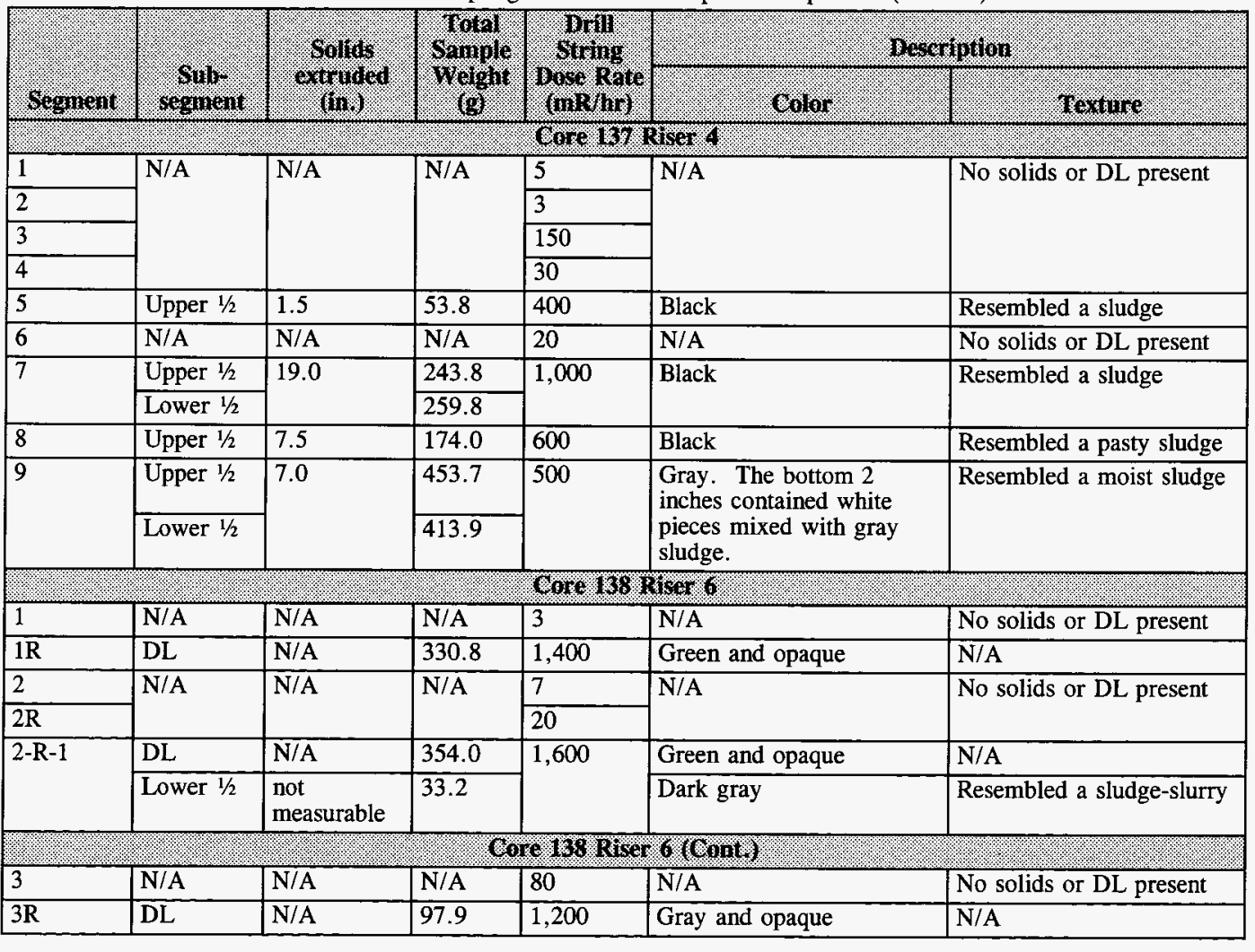


Table 3-2. Subsampling Scheme and Sample Description' ${ }^{1}$. (3 sheets)

\begin{tabular}{|c|c|c|c|c|c|c|}
\hline \multirow[b]{2}{*}{ Segznent } & \multirow[b]{2}{*}{$\begin{array}{l}\text { Sub } \\
\text { segunent }\end{array}$} & \multirow{2}{*}{$\begin{array}{l}\text { Solits } \\
\text { exrruded } \\
(\mathrm{min})\end{array}$} & \multirow{2}{*}{$\begin{array}{l}\text { Towil } \\
\text { Sample } \\
\text { Weight } \\
\text { (g) }\end{array}$} & \multirow{2}{*}{ 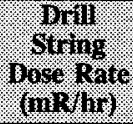 } & \multicolumn{2}{|c|}{ Descripition } \\
\hline & & & & & Color & Texture \\
\hline $3 \mathrm{AR}$ & Whole & 14 & 393.6 & 250 & Dark gray & Resembled a sludge. \\
\hline 4 & \multirow{2}{*}{$\mathrm{N} / \mathrm{A}$} & \multirow[t]{2}{*}{ N/A } & \multirow[t]{2}{*}{ N/A } & 40 & \multirow{2}{*}{ N/A } & \multirow{2}{*}{ No solids or DL present } \\
\hline $4 \mathrm{R}$ & & & & 5 & & \\
\hline \multirow[t]{2}{*}{5} & Upper $1 / 2$ & \multirow[t]{2}{*}{18.0} & 212.4 & \multirow{2}{*}{1,300} & \multirow[t]{2}{*}{ Dark brown } & \multirow[t]{2}{*}{ Resembled a sludge } \\
\hline & Lower $1 / 2$ & & 222.0 & & & \\
\hline \multirow[t]{2}{*}{6} & Upper $1 / 2$ & \multirow[t]{2}{*}{17.0} & 220.3 & \multirow[t]{2}{*}{1,200} & \multirow[t]{2}{*}{ Dark gray } & \multirow{2}{*}{$\begin{array}{l}\text { Resembled a very damp } \\
\text { sludge }\end{array}$} \\
\hline & Lower $1 / 2$ & & 209.9 & & & \\
\hline \multirow[t]{2}{*}{7} & Upper $1 / 2$ & \multirow[t]{2}{*}{18.0} & 83.9 & \multirow[t]{2}{*}{1,000} & \multirow[t]{2}{*}{ Dark brown to black } & \multirow[t]{2}{*}{ Resembled a sludge } \\
\hline & Lower $1 / 2$ & & 116.7 & & & \\
\hline \multirow[t]{2}{*}{8} & Upper $1 / 2$ & \multirow[t]{2}{*}{16.0} & 184.9 & \multirow[t]{2}{*}{800} & \multirow[t]{2}{*}{ Dark gray } & \multirow[t]{2}{*}{ Resembled a damp sludge } \\
\hline & Lower $1 / 2$ & & 180.3 & & & \\
\hline \multirow[t]{2}{*}{9} & Upper $1 / 2$ & \multirow[t]{2}{*}{12.0} & 185.6 & \multirow[t]{2}{*}{500} & \multirow[t]{2}{*}{ Dark gray to dark brown } & \multirow[t]{2}{*}{ Resembled a sludge } \\
\hline & Lower $1 / 2$ & & 132.8 & & & \\
\hline $\begin{array}{l}\text { Field } \\
\text { Blank }\end{array}$ & DL & N/A & 115.6 & $<0.5$ & Clear and colorless & N/A \\
\hline
\end{tabular}


Table 3-2. Subsampling Scheme and Sample Description'. (3 sheets)

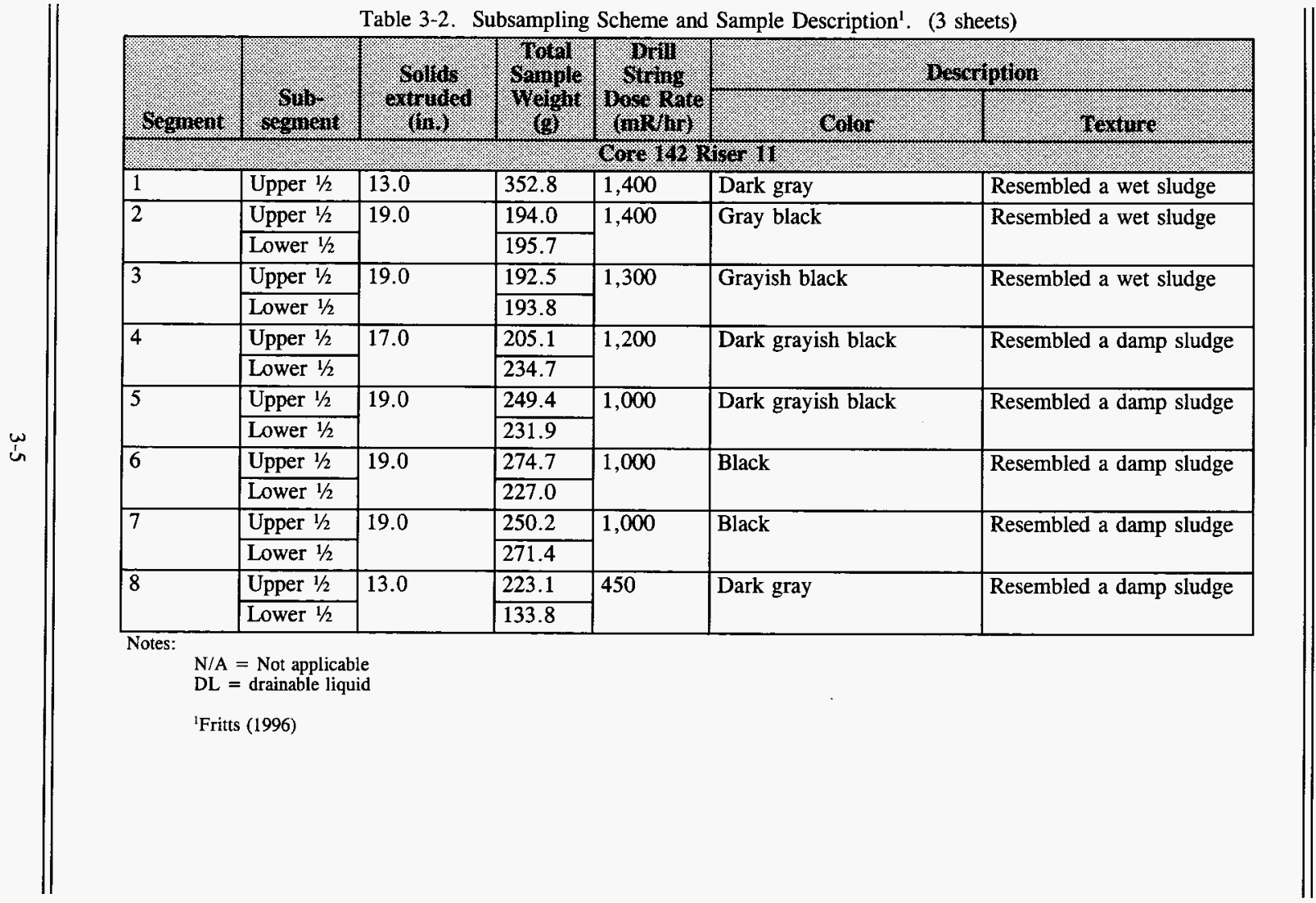




\subsection{SAMPLE ANALYSIS}

As noted in Table 3-1, the safety screening DQO required analyses for thermal properties by DSC, moisture by TGA, fissile content by total alpha analysis, and bulk density (specific gravity for the drainable liquid sample). In addition to the core samples, the flammability of the tank headspace was measured prior to core sampling.

Bromide analysis by IC and lithium analysis by ICP were required by the SAP to determine the amount of wash water contamination in the samples. Anion IC results and ICP data for other analytes were also reported in order to satisfy the requirements of the historical DQO.

The IC analyses were performed on each solid subsegment and core composite after preparation by a water leach, as required by the historical DQO. For all ICP analyses, the solid subsegments and core composites were prepared for analysis by acid and fusion digestion methods. In addition, a water-leached aliquot from each of the core composite samples was analyzed by ICP.

Laboratory control checks included, where appropriate, laboratory control standards, matrix spikes, duplicate analyses, and blanks. An assessment of the quality control (QC) procedures and the data is presented in Section 5.1.2 of this report.

All reported analyses were performed in accordance with approved laboratory procedures. A list of the sample numbers and applicable analyses is presented in Table 3-3. Table 3-4 displays the analytical procedures by title and number. No deviations or modifications were noted by the laboratory.

\subsection{DESCRIPTION OF EARLIER SAMPLING EVENTS}

This section presents a discussion of historical sampling and analysis events for tank 241-S-101. Data have been compiled for the samples obtained from the late 1950s to the present for single-shell tanks in the 200 East and West areas of the Hanford Site. The analytical results of five samples analyzed between 1971 and 1991 were obtained from historical records and are presented in Appendix C. A comparison between the 1991 results and the current sampling event is made in Section 5.2.

\subsubsection{Sample Handling and Analysis (1971)}

A sample was reported on September 21, 1971 in support of 242-S Evaporator operations. Neither the date of sample retrieval nor date of analysis is given. A description of the technique or procedure used to obtain the sample was not available, and no information concerning the sampled riser or sample depth was available. No information was available as to how the sample was handled once received for analysis. The data are presented in Appendix $\mathrm{C}$ for completeness, and if used, should be done so with caution. 
Table 3-3. Summary of Samples and Analyses. ${ }^{1}$ (5 sheets)

\begin{tabular}{|c|c|c|c|}
\hline Core & 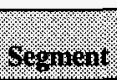 & $\begin{array}{l}\text { Seginent } \\
\text { Portion }\end{array}$ & (1.9. \\
\hline \multirow[t]{9}{*}{138} & 1R & DL & DSC, TGA, SpG, ICP (Acid dil.), IC, Alpha \\
\hline & \multirow[t]{2}{*}{2 R1 } & $\overline{\mathrm{DL}}$ & DSC, TGA, SpG, ICP (Acid dil.), IC, Alpha \\
\hline & & Lower $1 / 2$ & $\begin{array}{l}\text { Bulk Density } \\
\text { DSC, TGA } \\
\text { ICP (Fusion), GEA } \\
\text { ICP (Acid) } \\
\text { IC }\end{array}$ \\
\hline & $3 \mathrm{R}$ & $\mathrm{DL}$ & DSC, TGA, SpG, ICP (Acid dil.), IC, Alpha \\
\hline & $\overline{\mathrm{AR}}$ & Whole & $\begin{array}{l}\text { DSC, TGA } \\
\text { ICP (Fusion), GEA, Alpha }\end{array}$ \\
\hline & \multirow[t]{2}{*}{5} & Upper $1 / 2$ & $\begin{array}{l}\text { Bulk Density } \\
\text { DSC, TGA } \\
\text { ICP (Fusion), GEA } \\
\text { ICP (Acid) } \\
\text { IC }\end{array}$ \\
\hline & & Lower $1 / 2$ & $\begin{array}{l}\text { Bulk Density } \\
\text { DSC, TGA } \\
\text { ICP (Fusion), Alpha } \\
\text { ICP (Acid) } \\
\text { IC } \\
\end{array}$ \\
\hline & \multirow[t]{2}{*}{6} & Upper $1 / 2$ & \begin{tabular}{|l|} 
Bulk Density \\
DSC, TGA \\
ICP (Fusion), GEA \\
ICP (Acid) \\
IC \\
\end{tabular} \\
\hline & & Lower $1 / 2$ & $\begin{array}{l}\text { Bulk Density } \\
\text { DSC, TGA } \\
\text { ICP (Fusion), GEA, Alpha } \\
\text { ICP (Acid) } \\
\text { IC }\end{array}$ \\
\hline
\end{tabular}


WHC-SD-WM-ER-613 Rev. 0

Table 3-3. Summary of Samples and Analyses. ${ }^{1}$ (5 sheets)

\begin{tabular}{|c|c|c|c|}
\hline $80 \%$ & Socingat & 9001010 & 6amiser \\
\hline \multirow[t]{8}{*}{138} & \multirow[t]{2}{*}{7} & Upper $1 / 2$ & $\begin{array}{l}\text { Bulk Density } \\
\text { DSC, TGA } \\
\text { ICP (Fusion), GEA } \\
\text { ICP (Acid) } \\
\text { IC }\end{array}$ \\
\hline & & Lower $1 / 2$ & $\begin{array}{l}\text { Bulk Density } \\
\text { DSC, TGA } \\
\text { ICP (Fusion), GEA, Alpha } \\
\text { ICP (Acid) } \\
\text { IC }\end{array}$ \\
\hline & \multirow[t]{2}{*}{8} & Upper $1 / 2$ & $\begin{array}{l}\text { Bulk Density } \\
\text { DSC, TGA } \\
\text { ICP (Fusion), GEA } \\
\text { ICP (Acid) } \\
\text { IC }\end{array}$ \\
\hline & & Lower $1 / 2$ & $\begin{array}{l}\text { Bulk Density } \\
\text { DSC, TGA } \\
\text { ICP (Fusion), GEA, Alpha } \\
\text { ICP (Acid) } \\
\text { IC }\end{array}$ \\
\hline & \multirow[t]{2}{*}{9} & LL & $\begin{array}{l}\text { DSC, SpG, TGA, TIC, TOC, ICP (Acid), IC, } \\
\text { Alpha }\end{array}$ \\
\hline & & Upper $1 / 2$ & $\begin{array}{l}\text { Bulk Density } \\
\text { DSC, TGA } \\
\text { ICP (Fusion), GEA } \\
\text { ICP (Acid) } \\
\text { IC }\end{array}$ \\
\hline & \multicolumn{2}{|c|}{ Field Blank } & DSC, SpG, TGA, ICP (Acid dil.), IC, Alpha \\
\hline & \multicolumn{2}{|c|}{ Composite } & $\begin{array}{l}\text { Bulk Density } \\
\text { DSC, TGA, TIC, TOC } \\
\text { ICP (Fusion), GEA, Alpha, Beta, U, }{ }^{89 / 90} \mathrm{Sr} \\
\text { ICP (Acid) } \\
\text { IC } \\
\text { ICP (Water) }\end{array}$ \\
\hline
\end{tabular}


Table 3-3. Summary of Samples and Analyses. ${ }^{1}$ ( 5 sheets)

\begin{tabular}{|c|c|c|c|}
\hline Core & Sog ginent & $\begin{array}{l}\text { Segunarit } \\
\text { Portion. }\end{array}$ & (2) \\
\hline \multirow[t]{8}{*}{142} & 1 & Upper $1 / 2$ & $\begin{array}{l}\text { Bulk Density } \\
\text { DSC, TGA } \\
\text { ICP (Fusion), GEA, Alpha } \\
\text { ICP (Acid) } \\
\text { IC }\end{array}$ \\
\hline & \multirow[t]{2}{*}{2} & Upper $1 / 2$ & $\begin{array}{l}\text { Bulk Density } \\
\text { DSC, TGA } \\
\text { ICP (Fusion), GEA } \\
\text { ICP (Acid) } \\
\text { IC }\end{array}$ \\
\hline & & Lower $1 / 2$ & $\begin{array}{l}\text { Bulk Density } \\
\text { TGA, DSC } \\
\text { ICP (Fusion), GEA, Alpha } \\
\text { ICP (Acid) } \\
\text { IC }\end{array}$ \\
\hline & \multirow[t]{2}{*}{3} & Upper $1 / 2$ & $\begin{array}{l}\text { Bulk Density } \\
\text { DSC, TGA } \\
\text { ICP (Fusion), GEA } \\
\text { ICP (Acid) } \\
\text { IC }\end{array}$ \\
\hline & & Lower $1 / 2$ & $\begin{array}{l}\text { Bulk Density } \\
\text { DSC, TGA } \\
\text { ICP (Fusion), GEA, Alpha } \\
\text { ICP (Acid) } \\
\text { IC }\end{array}$ \\
\hline & \multirow[t]{2}{*}{4} & Upper $1 / 2$ & $\begin{array}{l}\text { Bulk Density } \\
\text { DSC, TGA } \\
\text { ICP (Fusion), GEA } \\
\text { ICP (Acid) } \\
\text { IC }\end{array}$ \\
\hline & & Lower $1 / 2$ & $\begin{array}{l}\text { Bulk Density } \\
\text { DSC, TGA } \\
\text { ICP (Fusion), GEA, Alpha } \\
\text { ICP (Acid) } \\
\text { IC }\end{array}$ \\
\hline & 5 & Upper $1 / 2$ & \begin{tabular}{|l} 
Bulk Density \\
DSC, TGA \\
ICP (Fusion), GEA \\
ICP (Acid) \\
IC
\end{tabular} \\
\hline
\end{tabular}


Table 3-3. Summary of Samples and Analyses. ${ }^{1}$ (5 sheets)

\begin{tabular}{|c|c|c|c|}
\hline Corte & Segrivent & $\begin{array}{l}\text { Segmerit } \\
\text { roution }\end{array}$ & Thatyses \\
\hline \multirow[t]{5}{*}{142} & 5 & Lower $1 / 2$ & $\begin{array}{l}\text { Bulk Density } \\
\text { DSC, TGA } \\
\text { ICP (Fusion), GEA, Alpha } \\
\text { ICP (Acid) } \\
\text { IC }\end{array}$ \\
\hline & \multirow[t]{2}{*}{6} & Upper $1 / 2$ & $\begin{array}{l}\text { Bulk Density } \\
\text { DSC, TGA } \\
\text { ICP (Fusion), GEA } \\
\text { ICP (Acid) } \\
\text { IC }\end{array}$ \\
\hline & & Lower $1 / 2$ & $\begin{array}{l}\text { Bulk Density } \\
\text { DSC, TGA } \\
\text { ICP (Fusion), GEA } \\
\text { ICP (Acid) } \\
\text { IC }\end{array}$ \\
\hline & \multirow[t]{2}{*}{7} & Upper $1 / 2$ & $\begin{array}{l}\text { Bulk Density } \\
\text { DSC, TGA } \\
\text { ICP (Fusion), GEA } \\
\text { ICP (Acid) } \\
\text { IC }\end{array}$ \\
\hline & & Lower $1 / 2$ & $\begin{array}{l}\text { Bulk Density } \\
\text { DSC, TGA } \\
\text { ICP (Fusion), GEA } \\
\text { ICP (Acid) } \\
\text { IC }\end{array}$ \\
\hline
\end{tabular}


Table 3-3. Summary of Samples and Analyses. ${ }^{1}$ (5 sheets)

\begin{tabular}{|c|c|c|c|}
\hline Core: & Segnent & Sogmention & $4 y_{11} y_{s e c}$ \\
\hline \multirow[t]{3}{*}{142} & \multirow[t]{2}{*}{8} & Upper $1 / 2$ & $\begin{array}{l}\text { Bulk Density } \\
\text { DSC, TGA } \\
\text { ICP (Fusion), GEA } \\
\text { ICP (Acid) } \\
\text { IC }\end{array}$ \\
\hline & & Lower $1 / 2$ & $\begin{array}{l}\text { Bulk Density } \\
\text { DSC, TGA } \\
\text { ICP (Fusion), GEA, Alpha } \\
\text { ICP (Acid) } \\
\text { IC }\end{array}$ \\
\hline & \multicolumn{2}{|c|}{ Composite } & $\begin{array}{l}\text { Bulk Density } \\
\text { DSC, TGA, TIC, TOC } \\
\text { ICP (Fusion), GEA, Alpha, Beta, U, }{ }^{8999} \mathrm{Sr} \\
\text { ICP (Acid) } \\
\text { IC } \\
\text { ICP (Water) }\end{array}$ \\
\hline $\begin{array}{l}\text { Vapor } \\
\text { Tests }\end{array}$ & \multicolumn{2}{|c|}{ Tank Headspace } & $\begin{array}{l}\text { Combustible gas meter readings for flammable } \\
\text { gas }\end{array}$ \\
\hline
\end{tabular}

Notes:

$\begin{array}{lll}\text { Dil. } & =\text { dilution } \\ \text { GEA } & =\text { gamma energy analysis }\end{array}$

${ }^{1}$ Fritts (1996) 
Table 3-4. Analytical Procedures. ${ }^{1}$

\begin{tabular}{|c|c|c|c|}
\hline aralysis? & (1mstrument & $\begin{array}{l}\text { Preparation } \\
\text { Procedure. }\end{array}$ & Aribtical Procedine? \\
\hline Energetics by DSC & $\begin{array}{l}\text { Mettler }^{\mathrm{TM}} \\
\text { Perkin-Elmer }\end{array}$ & N/A & $\begin{array}{l}\text { LA-514-113, Rev. C-1 } \\
\text { LA-514-114, Rev. C-1 }\end{array}$ \\
\hline $\begin{array}{l}\text { Percent water by } \\
\text { TGA }\end{array}$ & $\begin{array}{l}\text { Mettler }^{\mathrm{TM}} \\
\text { Perkin-Elmer }\end{array}$ & N/A & $\begin{array}{l}\text { LA-560-112, Rev. B-1 } \\
\text { LA-514-114, Rev. C-1 }\end{array}$ \\
\hline Total alpha activity & $\begin{array}{l}\text { Alpha } \\
\text { proportional } \\
\text { counter }\end{array}$ & $\begin{array}{l}\text { Fusion digest on solid } \\
\text { samples, LA-549-141, } \\
\text { Rev. F-0; Direct on } \\
\text { liquid samples }\end{array}$ & LA-508-101, Rev. D-2 \\
\hline Bulk density & N/A & N/A & LO-160-103, Rev. B-0 \\
\hline Specific gravity & N/A & N/A & LA-510-112, Rev. C-3 \\
\hline $\begin{array}{l}\text { Lithium and other } \\
\text { metals by ICP }\end{array}$ & $\begin{array}{l}\text { Inductively } \\
\text { coupled plasma } \\
\text { spectrometer }\end{array}$ & $\begin{array}{l}\text { LA-549-141, Rev. F-0 } \\
\text { LA-505-159, Rev. D-0 } \\
\text { LA-504-101, Rev. E-0 }\end{array}$ & $\begin{array}{l}\text { LA-505-151, Rev. D-3 } \\
\text { LA-505-161, Rev. B-1 }\end{array}$ \\
\hline $\begin{array}{l}\text { Bromide and other } \\
\text { anions by IC }\end{array}$ & $\begin{array}{l}\text { Ion } \\
\text { chromatograph }\end{array}$ & $\begin{array}{l}\text { Water leach } \\
\text { LA-504-101, Rev. E-0 }\end{array}$ & LA-533-105, Rev. D-1 \\
\hline TIC & Coulometer & $\mathrm{N} / \mathrm{A}$ & LA-342-100, Rev. D-0 \\
\hline TOC & Coulometer & N/A & LA-342-100, Rev. D-0 \\
\hline GEA & $\begin{array}{l}\text { Gamma } \\
\text { spectrometer }\end{array}$ & \multirow[t]{3}{*}{$\begin{array}{l}\text { Fusion digest } \\
\text { LA-549-141, Rev. F-0 }\end{array}$} & LA-548-121, Rev. D-1 \\
\hline${ }^{90} \mathrm{Sr}$ & $\begin{array}{l}\text { Beta proportional } \\
\text { counter }\end{array}$ & & LA-220-101, Rev. D-1 \\
\hline Total beta & $\begin{array}{l}\text { Beta proportional } \\
\text { counter }\end{array}$ & & LA-508-101, Rev. D-2 \\
\hline Uranium & $\begin{array}{l}\text { Laser } \\
\text { phosphorimeter }\end{array}$ & $\begin{array}{l}\text { Fusion digest } \\
\text { LA-549-101, Rev. F-0 }\end{array}$ & LA-925-009, Rev. A-1 \\
\hline Flammable Gas & $\begin{array}{l}\text { Combustible gas } \\
\text { meter }\end{array}$ & N/A & $\begin{array}{l}\text { WHC-IP-030, IH } 1.4 \\
\text { and IH } 2.1\end{array}$ \\
\hline
\end{tabular}

Notes:

Rev. = revision

Mettler $^{\mathrm{TM}}$ is a registered trademark of Mettler Electronics, Anaheim, California.

Perkin-Elmer ${ }^{T M}$ is a registered trademark of Perkins Research and Manufacturing Company, Inc.,

Canoga Park, California.

TIC $=$ total inorganic carbon

'Fritts (1996)

${ }^{2}$ Internal procedures of Westinghouse Hanford Company, Richland, Washington. 


\subsubsection{Sample Handling and Analysis (1974)}

A sample was received on September 13, 1974, and reported on December 20, 1974. A description of the technique or procedure used to obtain the sample was not available, and no information concerning the sampled riser or sample depth was available. No information was available as to how the sample was handled once received for analysis. The data are presented in Appendix $\mathrm{C}$ for completeness, and if used, should be done so with caution.

\subsubsection{Sample Handling and Analysis (1975)}

A sample was received on June 4, 1975, and reported on July 16, 1975. The sample was dark brown in color and had the consistency of soft mud. A description of the technique or procedure used to obtain the sample was not available, and no information concerning the sampled riser or sample depth was available. The sample was prepared by fusing a known volume of solids with $\mathrm{KOH}$, dissolving the melt with concentrated $\mathrm{HCl}$, and then diluting with water. The data are presented in Appendix $\mathrm{C}$ for completeness, and if used, should be done so with caution.

A sample was received on November 19, 1975, and reported on December 5, 1975. A description of the technique or procedure used to obtain the sample was not available, and no information concerning the sampled riser or sample depth was available. No information was available as to how the sample was handled once received for analysis.

\subsubsection{Sample Handling and Analysis (1991)}

A sample identified as T-8579 was received on December 17, 1991, and reported on December 30,1991. A description of the technique or procedure used to obtain the sample was not available, and no information concerning the sampled riser or sample depth was available. No information was available as to how the sample was handled once received for analysis. The data are presented in Appendix $\mathrm{C}$ for completeness, and if used, should be done so with caution. 
WHC-SD-WM-ER-613 Rev. 0

This page intentionally left blank. 


\subsection{ANALYTICAL RESULTS}

This section presents a summary of the analytical results associated with the March/April 1996 core sampling event of tank 241-S-101. This plan integrates all documents related to sampling and analytical requirements, including applicable DQOs. All analyses were performed at the Westinghouse Hanford Company 222-S Laboratory.

Tabulated locations of analytical results are given in Table 4-1. Comprehensive analytical data are found in Appendix A. Only analyte overall means are reported in Section 4.0. Appendix B contains data for lithium and bromide, the analytes evaluated to gauge the amount of contamination by the wash water used during sampling. These analytes are not part of the waste in the tank.

Table 4-1. Analytical Data Presentation Tables.

\begin{tabular}{|l|l|}
\hline \multicolumn{1}{|c|}{ Bata Thes } & Tabulated location \\
\hline Chemical data summary & Table 4-2 \\
\hline DSC exothermic data summary & Table 4-3 \\
\hline Comprehensive analytical data & Appendix A \\
\hline Wash water contamination check data & Appendix B \\
\hline Historical sampling data & Appendix C \\
\hline
\end{tabular}

\subsection{DATA PRESENTATION}

This section presents a summary of the analytical results associated with the March/April 1996 core sampling event of tank 241-S-101. The subsections below provide information about the chemical, physical, vapor, and wash water contamination check data. The analytical data were tabulated in Final Results for Tank 241-S-101, Cores 137, 138, and 142 (Fritts 1996).

\subsubsection{Chemical Data Summary}

Table 4-2 presents the mean concentration estimates and inventories for the solid and liquid results separately, as well as a total tank inventory based on both waste phases. Data from cores 138 and 142 were combined to derive the overall concentration means for all analytes. The overall means are weighted means, and were calculated by first averaging the individual 
primary and duplicate results for each subsegment to obtain a subsegment mean. Next, the segment means for an individual core were averaged to derive a core mean. Finally, the two core means were averaged to obtain the overall mean. Not all of these steps are necessary for each analyte or each subsegment, but the procedure to be followed is the same. When 50 percent or more of the individual primary/duplicate measurements had detected results, the overall mean was reported as a detected value. Conversely, when results for more than half of the individual primary/duplicate results were nondetected, the overall mean was reported as a less than $(<)$ value. When nondetected values are used as qualitative results the mean concentration and inventory estimates are biased. The magnitude of the bias cannot be determined, but the bias is to more conservative concentration estimates. These particular results should be used with caution.

Table 4-2 presents the overall means in columns two and five for the liquid and solid portions of the waste, respectively. The original subsegment analytical data are listed in Appendix A.

Relative standard deviations of the mean (RSD [Mean]), defined as 100 times the standard deviation of the mean divided by the tank mean, were calculated using standard analysis of variance (ANOVA) techniques (nested models). They are reported in columns three and six of Table 4-2, and were calculated only for those analytes that had 50 percent or more of their individual primary/duplicate results above the detection limit. Using nondetected results in the mean calculation also requires their use in the RSD (mean) calculations. Whereas the use of nondetected results in the mean calculations produces a known high bias, using these values in statistical calculations creates an unknown bias. Thus, the RSD (mean) estimates and the ANOVA results in which nondetected data were used should be used with caution.

The liquid inventory, presented in column four, was calculated by multiplying the overall mean by the supernatant waste volume ( $45 \mathrm{~kL}$ [12 kgal]), and dividing by a unit conversion factor of $1 \mathrm{E}+03$. The solid inventory, presented in column seven, was calculated by multiplying the overall mean by the mean solid density $(1.65 \mathrm{~g} / \mathrm{mL})$ and the solid waste volume $(1,571 \mathrm{~kL}$ [415 kgal]), and dividing by a unit conversion factor of $1 \mathrm{E}+03$. Total inventory results are the summation of the liquid and solid inventories, and are listed in column eight. 
Table 4-2. Solid and Liquid Chemical Data Summary for Tank 241-S-101. (4 Sheets)

\begin{tabular}{|c|c|c|c|c|c|c|c|}
\hline Whor & 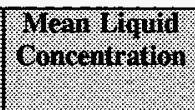 & 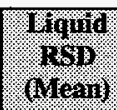 & 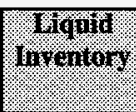 & 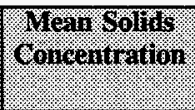 & 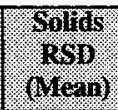 & 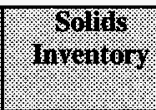 & 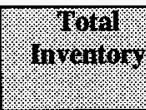 \\
\hline Aluminum & 24,500 & 2.9 & 1,100 & $80,500^{1}$ & 14.7 & $2.09 \mathrm{E}+05$ & $2.10 \mathrm{E}+05$ \\
\hline Antimony & $<24.1$ & N/A & $<1.08$ & $<23.2$ & N/A & $<60.1$ & $<61.2$ \\
\hline Beryllium & $<2.00$ & N/A & $<0.0900$ & $<1.94$ & N/A & $<5.03$ & $<5.12$ \\
\hline Bismuth & $<40.1$ & N/A & $<1.80$ & $<47.5$ & N/A & $<123$ & $<125$ \\
\hline Boron & 70.4 & 1.5 & 3.17 & 86.6 & 24.1 & 224 & 227 \\
\hline Cadmium & $<2.00$ & N/A & $<0.0900$ & 4.46 & 31.4 & 11.6 & 11.7 \\
\hline Calcium & $<40.1$ & N/A & $<1.80$ & 329 & 10.5 & 853 & 855 \\
\hline Copper & $<4.01$ & N/A & $<0.180$ & 12.7 & 21.4 & 32.9 & 33.1 \\
\hline Iron & $<20.1$ & N/A & $<0.905$ & $1,360^{\top}$ & 8.2 & 3,530 & 3,530 \\
\hline Lanthanum & $<20.1$ & N/A & $<0.905$ & $<19.6$ & N/A & $<50.8$ & $<51.7$ \\
\hline Lead & $<40.1$ & $\mathrm{~N} / \mathrm{A}$ & $<1.80$ & $<51.5$ & N/A & $<133$ & $<135$ \\
\hline Magnesium & $<40.1$ & N/A & $<1.80$ & $<42.3$ & $\mathrm{~N} / \overline{\mathrm{A}}$ & $<110$ & $<112$ \\
\hline Manganese & $<4.01$ & N/A & $<0.180$ & $1,540^{1}$ & 17.8 & 3,990 & 3,990 \\
\hline Molybdenum & 84.6 & 3.2 & 3.81 & 33.4 & 13.3 & 86.8 & 90.6 \\
\hline
\end{tabular}


Table 4-2. Solid and Liquid Chemical Data Summary for Tank 241-S-101. (4 Sheets)

\begin{tabular}{|c|c|c|c|c|c|c|c|}
\hline (2. & 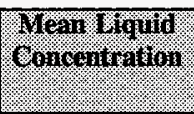 & 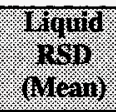 & liveriory. & $\begin{array}{l}\text { Wean Sollos } \\
\text { Toncentranton }\end{array}$ & 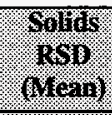 & morentory & Inrenorol \\
\hline Neodymium & $<40.1$ & $\mathrm{~N} / \mathrm{A}$ & $<1.80$ & $<41.6$ & $\mathrm{~N} / \mathrm{A}$ & $<108$ & $<110$ \\
\hline Nickel & $<8.02$ & N/A & $<0.361$ & 89.9 & 19.2 & 233 & 233 \\
\hline Samarium & $<40.1$ & N/A & $<1.80$ & $<38.7$ & N/A & $<100$ & $<102$ \\
\hline Selenium & $<43.0$ & N/A & $<1.94$ & $<38.7$ & N/A & $<100$ & $<102$ \\
\hline Silicon & 164 & 19.3 & 7.38 & $<1,390^{1}$ & N/A & $<3,600$ & $<3,610$ \\
\hline Silver & 15.3 & 1.1 & 0.689 & 10.9 & 6.2 & 28.3 & 29.0 \\
\hline Titanium & $<4.01$ & N/A & $<0.180$ & 5.84 & 14.3 & 15.1 & 15.3 \\
\hline Uranium & $<200$ & N/A & $<9.00$ & 4,680 & 23.9 & 12,100 & 12,100 \\
\hline Vanadium & $<20.1$ & N/A & $<0.905$ & $<19.4$ & N/A & $<50.3$ & $<51.2$ \\
\hline Zinc & 28.6 & 27.5 & 1.29 & 27.8 & 7.0 & 72.1 & 73.4 \\
\hline Zirconium & $<4 . \overline{01}$ & $\overline{\mathrm{N}} / \mathrm{A}$ & $<0.180$ & 22.7 & 16.5 & 58.8 & 60.0 \\
\hline
\end{tabular}


Table 4-2. Solid and Liquid Chemical Data Summary for Tank 241-S-101. (4 Sheets)

\begin{tabular}{|c|c|c|c|c|c|c|c|}
\hline Wrayles: & 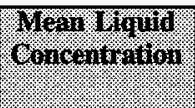 & 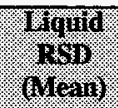 & W100110\% & 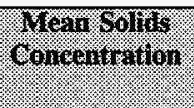 & 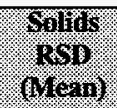 & 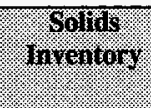 & Insentory \\
\hline Chloride & 7,450 & 1.3 & 335 & 3,460 & 9.5 & 8,970 & 9,310 \\
\hline Fluoride & $<106$ & N/A & $<4.77$ & $<233$ & N/A & 596 & 601 \\
\hline Oxalate & $<858$ & N/A & $<38.6$ & 5,700 & 44.7 & 14,800 & 14,800 \\
\hline Phosphate & 3,600 & 6.1 & 162 & 3,680 & 56.3 & 9,540 & 9,700 \\
\hline Sulfate & 5,650 & 4.6 & 254 & 7,250 & 46.1 & 18,800 & 19,100 \\
\hline HAOOMOMWOS & 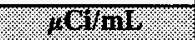 & 48 & (1) & III & $=\%$ & W & 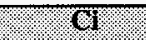 \\
\hline Total alpha & $<0.00810$ & N/A & $<21.0$ & 0.358 & 24.0 & 928 & 949 \\
\hline${ }^{60} \mathrm{Co}$ & --- & -- & --- & $<0.190$ & N/A & $<493$ & $<493$ \\
\hline${ }^{154} \mathrm{Eu}$ & -- & --- & -- & $<0.557$ & N/A & $<1,440$ & $<1,440$ \\
\hline${ }^{155} \mathrm{Eu}$ & --- & --- & -- & $<1.06$ & N/A & $<2,750$ & $<2,750$ \\
\hline${ }^{89 / 90} \mathrm{Sr}$ & --- & -- & $\cdots$ & $252^{2}$ & 19.6 & $6.53 \mathrm{E}+05$ & $6.53 \mathrm{E}+05$ \\
\hline
\end{tabular}


Table 4-2. Solid and Liquid Chemical Data Summary for Tank 241-S-101. (4 Sheets)

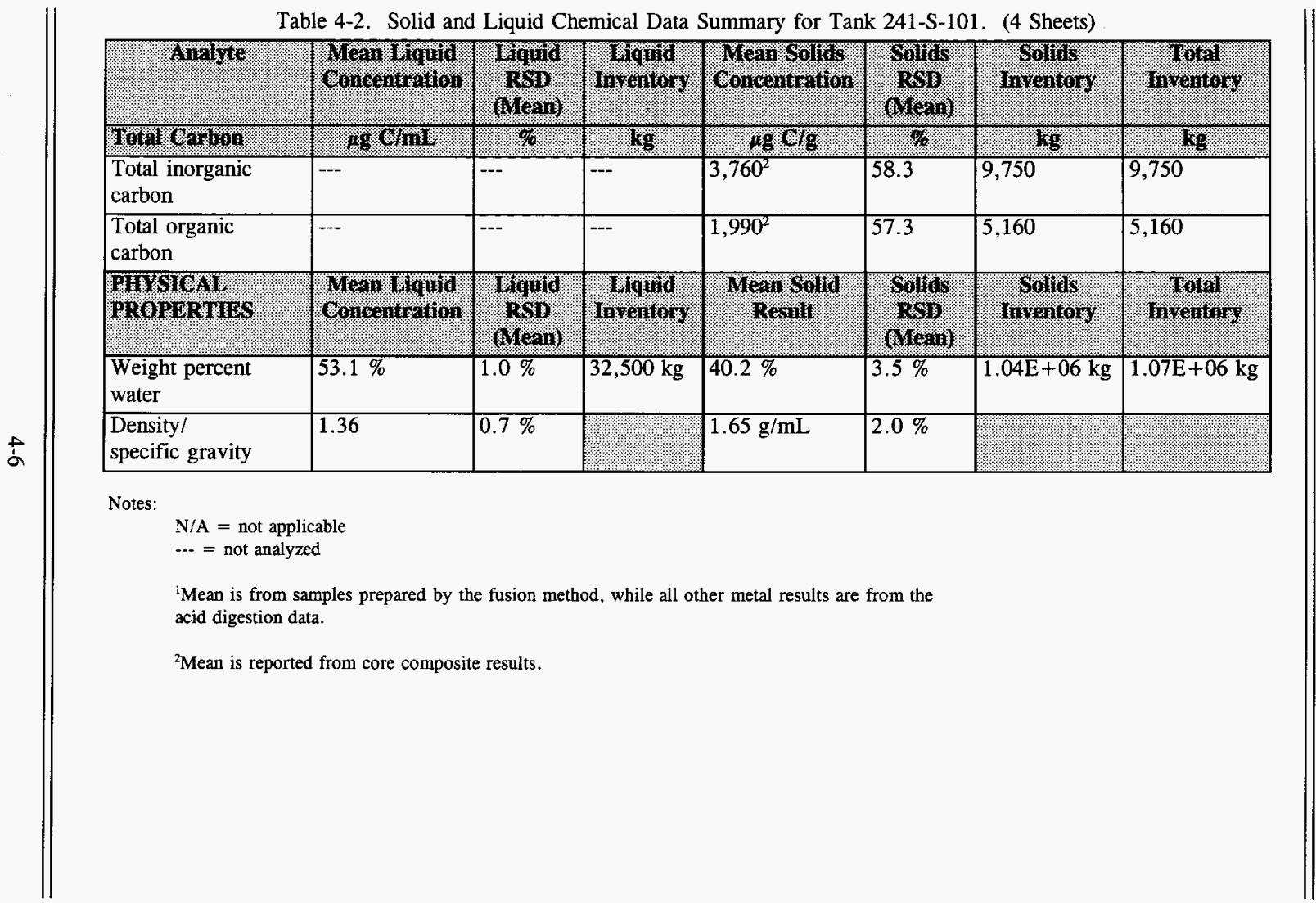




\subsubsection{Physical Data Summary}

Thermal analyses were performed on the tank 241-S-101 samples to satisfy the requirements of the safety screening DQO (Dukelow et al. 1995) and the historical DQO (Simpson and McCain 1995), which dictated that TGA and DSC be performed on the samples. Density determinations were also performed on the samples as mandated by the DQOs.

4.1.2.1 Thermogravimetric Analysis. In a TGA, the mass of a sample is measured while its temperature is increased at a constant rate. Nitrogen is passed over the sample during the heating to remove any released gases. Any decrease in the weight of a sample represents a loss of gaseous matter from the sample either through evaporation or through a reaction that forms gas phase products. The moisture content is estimated by assuming that all TGA sample weight loss up to a certain temperature (typically $150^{\circ} \mathrm{C}\left[302{ }^{\circ} \mathrm{F}\right]$ ) is due to water evaporation. Weight percent water by TGA was performed by the 222-S Laboratory using procedures LA-560-112, Rev. B-1 (Mettler ${ }^{\mathrm{TM}}$ ) or LA-514-114, Rev. C-1 (Perkin-Elmer ${ }^{\mathrm{TM}}$ ).

The TGA percent water data for tank 241-S-101 are presented in Table A-57 of Appendix A. The overall mean percent water for the solids, other than those of the composites, was 40.2 weight percent, while the liquid overall mean was 53.1 weight percent.

4.1.2.2 Differential Scanning Calorimetry. In a DSC analysis, heat absorbed or emitted by a substance is measured while the substance is heated at a constant rate of temperature. While the substance is being heated, a gas such as nitrogen is passed over the waste material to remove any gases being released. The onset temperature for an endothermic (characterized by or causing the absorption of heat) or exothermic (characterized by or causing the release of heat) event is measured with thermocouples and displayed graphically. Analyses by DSC were performed by the 222-S Laboratory using either procedure LA-514113, Rev. C-1 (Mettler ${ }^{\mathrm{TM}}$ ) or LA-514-114, Rev. C-1 (Perkin-Elmer $\left.{ }^{\mathrm{TM}}\right)$.

The DSC results are presented in Table A-56 of Appendix A. The sample weight, temperature at maximum enthalpy change, and the magnitude of the enthalpy change are provided for each transition. Four samples exhibited exothermic transitions. One sample was a liner liquid. Because exothermic reactions are associated with negative enthalpy changes, they have been denoted in Table A-56 with a negative sign. All results reported in the table are on a wet weight basis.

For a comparison of the exothermic enthalpy changes with the decision limit of $-480 \mathrm{~J} / \mathrm{g}$, the exothermic values were converted to a dry weight basis using the respective sample weight percent water. After conversion to a dry weight basis, it was determined that none of the samples exhibited enthalpy changes exceeding the $-480 \mathrm{~J} / \mathrm{g}$ limit. The upper limit to the one-sided 95 percent confidence intervals on the mean were calculated with, the largest sample result being $-310 \mathrm{~J} / \mathrm{g}$. 
Table 4-3 presents the three samples that had exothermic reactions, along with the weight percent water for conversion to a dry weight, the converted exothermic value, and the upper limits of the 95 percent confidence intervals.

Table 4-3. DSC Exothermic Results and 95 Percent Confidence Interval Upper Limits. ${ }^{1}$

\begin{tabular}{|c|c|c|c|c|c|c|c|}
\hline \multirow{2}{*}{ 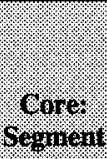 } & \multirow{2}{*}{ \%8110\% } & \multirow[b]{2}{*}{ Man } & Wetwh & 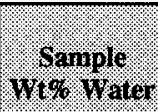 & Pov & Hen & 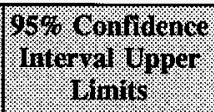 \\
\hline & & & 118 & 18 & 165 & 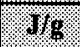 & 18 \\
\hline \multirow[t]{4}{*}{$142: 2$} & \multirow[t]{2}{*}{ Upper $1 / 2$} & 1 & $\begin{array}{l}-21.4 / \\
-42.8^{2}\end{array}$ & \multirow[t]{2}{*}{44.7} & -116.1 & \multirow[t]{2}{*}{-95.4} & \multirow[t]{2}{*}{-226} \\
\hline & & 2 & $\begin{array}{l}-7.6 / \\
-33.7^{2}\end{array}$ & & -74.7 & & \\
\hline & \multirow[t]{2}{*}{ Lower $1 / 2$} & 1 & -64.3 & \multirow[t]{2}{*}{42.8} & -112 & \multirow[t]{2}{*}{-93.6} & \multirow[t]{2}{*}{-210} \\
\hline & & 2 & $\begin{array}{l}-7.0 / \\
-36.0^{2}\end{array}$ & & -75.2 & & \\
\hline \multirow[t]{2}{*}{$142: 4$} & \multirow[t]{2}{*}{ Upper $1 / 2$} & 1 & -10.9 & \multirow[t]{2}{*}{40.1} & -18.2 & \multirow[t]{2}{*}{-9.1} & \multirow[t]{2}{*}{-66.6} \\
\hline & & 2 & 0 & & 0 & & \\
\hline
\end{tabular}

Notes:

${ }^{1}$ Fritts (1996)

${ }^{2}$ The exothermic reactions for this sample came from the third transition. All other results are from the second transition.

4.1.2.3 Density/Specific Gravity. Bulk density measurements were performed on solid samples using procedure LO-160-103, Rev. B-0. Specific gravity measurements were performed on the liquid samples using procedure LA-510-112, Rev. C-3. The mean density of the solids was $1.65 \mathrm{~g} / \mathrm{mL}$ and the mean specific gravity of the liquid was 1.36 . The analytical data are presented in Table A-58 of Appendix A. 


\subsubsection{Tank Headspace Flammability}

As discussed in Section 3.1, sampling of the tank 241-S-101 headspace was performed prior to core sampling. The safety screening DQO decision limit for flammable gas concentration is 25 percent of the LFL (Dukelow et al. 1995). The combustible gas meter used for the sampling event reports results as a percentage of the lower explosive limit (LEL). Because the National Fire Protection Association defines the terms LFL and LEL identically, the two terms are used interchangeably (NFPA 1995). Sampling was done in the headspace through risers 7 and 9 between February 6 and February 21, 1996. The maximum value recorded in the headspace under risers 4 and 6 was 7 percent of the $\mathrm{LEL}$, indicating no flammability concerns. During the flammable gas monitoring, the maximum concentrations of oxygen (20.8 percent), total organic vapor $(31 \mathrm{ppm})$, and ammonia $(600 \mathrm{ppm})$ were also measured (Fritts 1996).

\subsubsection{Wash Water Contamination Check}

The wash water used during sampling operations contained a known concentration of lithium bromide. Through chemical analyses for lithium and bromide, as prescribed by the SAP (Kruger 1996), contamination of the samples by the wash water could be estimated. The results indicated that there was only a small amount of contamination in one of the samples. No adjustments to the TGA results were necessary. The analytical data for lithium and bromide are presented in Appendix B. An overall mean and tank inventory were not calculated for these two analytes because they are not constituents of the tank waste. 
WHC-SD-WM-ER-613 Rev. 0

This page intentionally left blank. 


\subsection{INTERPRETATION OF CHARACTERIZATION RESULTS}

The purpose of this chapter is to discuss the overall quality and consistency of the current sampling results for tank $241-\mathrm{S}-101$, and to assess and compare these results against historical information and program requirements.

\subsection{ASSESSMENT OF SAMPLING AND ANALYTICAL RESULTS}

This section evaluates sampling and analysis factors that may impact interpretation of the data. These factors are used to assess the overall quality and consistency of the data and to identify any limitations in the use of the data.

\subsubsection{Field Observations}

The safety screening DQO (Dukelow et al. 1995) requirement that at least two widely spaced risers be sampled was fulfilled. The requirement for vertical profiling was met, but not without difficulty. The requirement for vertical profiling was met, but not without difficulty. Segments 1 through 4 of core 138 initially had zero sample recovery and were resampled with similar results. The resampling of segment 1 provided drainable liquid, but no solids. Segment 2 was resampled twice more and on the last attempt provided drainable liquid and a small amount of solids. Segment 3 was also resampled twice. The first resampling recovered drainable liquid, while the last attempt recovered a small amount of solids. No sample was recovered from the resampling of segment 4 . No anomalies were reported during extrusion.

\subsubsection{Quality Control Assessment}

The usual quality control assessment includes an evaluation of the appropriate standard recoveries, matrix spike recoveries, duplicate analyses, and blanks that are performed in conjunction with the chemical analyses. All the pertinent quality control tests were conducted on the 1996 core samples, allowing a full assessment regarding the accuracy and precision of the data. The specific criteria for all QC checks were given in the SAP (Kruger 1996). Quality control results outside these criteria are identified by superscripts in the Appendix A tables.

The standard and matrix spike recovery results provide an estimate of the accuracy of the analysis. If a standard or spike recovery is above or below the given criterion, then the analytical results may be biased high or low, respectively. The analytical precision is evaluated by the relative percent difference (RPD), which is defined as the absolute value of the difference between the primary and duplicate samples, divided by their mean, multiplied by one hundred. 
All standard and matrix spike recoveries were within the SAP defined limits with the exception of high matrix spike recoveries for sodium. The high recoveries are not expected to affect the data. When the sample concentration is greater than the spike concentration by a factor of four or more, the matrix spike recovery should be evaluated with caution. The laboratory encountered calibration problems during the nitrite analysis of samples from core 138 . Because nitrite was not a required analyte per the SAP, the affected samples were not reanalyzed, and only nitrate data from segments $2 \mathrm{R} 1$ and 5 were reported. Three TGAs had RPD results outside the SAP specified limits. The samples were reanalyzed with duplicates producing acceptable results. Three other samples had RPDs between 17 and 20 percent. Two of these had triplicate analyses affected and the spread in the data was lessened. As 20 percent is the specified limit the calculated value for the third sample is reported. Four of the total alpha activity RPDs were outside the defined limits. No sample reanalyses were requested because the poor precision was attributed to low sample activity and data well below the decision criterion. Several analytes were determined by IC and ICP with RPDs outside the defined limits. The high RPDs for these analytes were attributed to sample inhomogeneity.

Finally, none of the samples exceeded the criterion for preparation blanks; thus, contamination was not a problem for any of the analyses. In summary, the majority of the QC results were within the boundaries specified in the SAP. Although a few were outside their target levels, they were not found to substantially impact either the validity or the use of the data.

\subsubsection{Data Consistency Checks}

Comparisons of results from different analytical methods can help assess the consistency and quality of the data. Checks can be made on some analytes when the same aliquot of sample is analyzed by two comparable analyses, or when two different methods were used to prepare the sample before analysis. The comparisons are limited because sampling effects caused by sample heterogeneity cannot be separated from differences in the methods. The calculation of mass and charge balances, along with comparisons of the ICP phosphorous and sulfur results with the IC phosphate and sulfate results, respectively. Only the solid portion of the waste was considered in these comparisons because it comprises 93 percent of the total waste.

5.1.3.1 Comparison of Results from Different Analytical Methods. The following data consistency checks compare the results from two different analytical methods. A close comparison strengthens the credibility of both results, whereas a poor comparison brings the reliability of the data into question. All analytical mean results were taken from Table 4-2. 
The analytical phosphorous mean by ICP was $1,400 \mu \mathrm{g} / \mathrm{g}$, which represents total phosphorous. This amount of phosphorous converts to $4,290 \mu \mathrm{g} / \mathrm{g}$ of phosphate. The IC phosphate result was $3,680 \mu \mathrm{g} / \mathrm{g}$ (ratio of 1.17 ). The ICP sulfur value of $1,960 \mu \mathrm{g} / \mathrm{g}$, which represents total sulfur, is equivalent to $5,880 \mu \mathrm{g} / \mathrm{g}$ of sulfate. The IC result for sulfate was $7,250 \mu \mathrm{g} / \mathrm{g}$ (ratio of 0.811 ). The sulfur results are contradictory to expected behavior. Because ICP measures total sulfur, its result is usually larger than or equal to the IC value, which is a measurement of the soluble sulfate. A possible explanation for the unexpected results is that some metal sulfates are insoluble in acid and more soluble in basic media. It is possible that the water leach performed prior to the IC analysis dissolved more of the sulfate than the acid digestion done before the ICP analysis.

5.1.3.2 Mass and Charge Balances. The principle objective in performing mass and charge balances is to determine if the measurements were consistent. In calculating the balances, only analytes listed in Table 4-2 detected at a concentration of $1,500 \mu \mathrm{g} / \mathrm{g}$ or greater were considered.

Except sodium, all cations listed in Table 5-1 were assumed to be in their most common hydroxide or oxide form, and the concentrations of the assumed species were calculated stoichiometrically. Because precipitates are neutral species, all positive charge was attributed to sodium. The anionic analytes listed in Table 5-2 were assumed to be present as sodium salts and were expected to balance the positive charge. Phosphorous and sulfur are assumed to be present as soluble phosphate and sulfate ions. The concentrations of cationic species in Table 5-1, the anionic species in Table 5-2, and the percent water were ultimately used to calculate the mass balance. The uncertainty estimates (RSDs) associated with each analyte are also given in the tables. The uncertainty estimates for the cation and anion totals, as well as the overall uncertainty given in Table 5-3, were computed by a statistical technique known as the propagation of errors (Nuclear Regulatory Commission 1988).

The mass balance was calculated from the formula below. The factor 0.0001 is the conversion factor from $\mu \mathrm{g} / \mathrm{g}$ to weight percent, $\mathrm{AlO}(\mathrm{OH})$ is the assumed species. There was no endotherm reported in the DSC analysis at $c a .330^{\circ} \mathrm{C}\left(626^{\circ} \mathrm{F}\right)$. Additionally, there is a difference between the measured values for $\mathrm{Al}$ concentration between the two preparation techniques. The $\mathrm{AlO}(\mathrm{OH})$ form is consistent with both of these observations.

Mass balance $=$ percent Water $+0.0001 \times$ \{Total Analyte Concentration $\}$ $=$ percent Water $+0.0001 \times\left\{\mathrm{AlO}(\mathrm{OH})+\mathrm{Cr}(\mathrm{OH})_{3}+\mathrm{MnO}(\mathrm{OH})+\right.$ $\mathrm{UO}_{3}+\mathrm{Na}^{+}+\mathrm{Cl}^{-}+\mathrm{NO}_{3}^{-}+\mathrm{NO}_{2}^{-}+\mathrm{CO}_{3}{ }^{2-}+\mathrm{C}_{2} \mathrm{O}_{4}{ }^{2-}+\mathrm{C}_{2} \mathrm{H}_{3} \mathrm{O}_{2}^{-}+$ $\left.\mathrm{PO}_{4}{ }^{3-}+\mathrm{SO}_{4}{ }^{2-}\right\}$. 
The total analyte concentrations calculated from the above equation is $605,000 \mu \mathrm{g} / \mathrm{g}$ (wet weight). The mean weight percent water obtained from thermogravimetric analysis reported in Table 4-2 is 40.2 percent, or $402,000 \mu \mathrm{g} / \mathrm{g}$. The mass balance resulting from adding the percent water to the total analyte concentration is 101 percent (Table 5-3).

The following equations demonstrate the derivation of total cations and total anions, and the charge balance is the ratio of these two values. To derive the results as shown in the equations, all concentrations must first be converted to a $\mu \mathrm{g} / \mathrm{g}$ basis.

Total cations $(\mu \mathrm{eq} / \mathrm{g})=\left[\mathrm{Na}^{+}\right] / 23.0=6,480 \mu \mathrm{eq} / \mathrm{g}$

Total anions $(\mu \mathrm{eq} / \mathrm{g})=\left[\mathrm{Cl}^{-}\right] / 35.5+\left[\mathrm{CO}_{3}{ }^{2-}\right] / 30.0+\left[\mathrm{C}_{2} \mathrm{O}_{4}{ }^{2-}\right] / 44.0+\left[\mathrm{C}_{2} \mathrm{H}_{3} \mathrm{O}_{2}{ }^{-}\right] / 59.0+$ $\left[\mathrm{NO}_{3}{ }^{-}\right] / 62.0+\left[\mathrm{NO}_{2}{ }^{-}\right] / 46.0+\left[\mathrm{PO}_{4}{ }^{3-}\right] / 31.7+\left[\mathrm{SO}_{4}{ }^{2-}\right] / 48.0$ $=4,880 \mu \mathrm{eq} / \mathrm{g}$.

The charge balance obtained by dividing the sum of the positive charge by the sum of the negative charge was 1.33 .

Table 5-1. Cation Mass and Charge Data. ${ }^{1}$

\begin{tabular}{|c|c|c|c|c|c|}
\hline \multirow[b]{2}{*}{ Analye } & $\begin{array}{l}\text { eoncentration } \\
\text { (net veight) }\end{array}$ & \multirow{2}{*}{$\begin{array}{l}\text { Asrumed } \\
\text { Splesies }\end{array}$} & $\begin{array}{l}\text { Concentration of } \\
\text { Assumed Species }\end{array}$ & RSB: & Gharge \\
\hline & 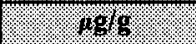 & & 1089 & 8 & 14.9/g \\
\hline Aluminum & $80,500^{2}$ & $\mathrm{AlO}(\mathrm{OH})$ & 179,000 & 14.7 & 0 \\
\hline Chromium & 7,250 & $\mathrm{Cr}(\mathrm{OH})_{3}$ & 14,400 & 20.5 & 0 \\
\hline Manganese & 1,540 & $\mathrm{MnO}(\mathrm{OH})$ & 2,460 & 17.8 & 0 \\
\hline Uranium & 4,680 & $\mathrm{UO}_{3}$ & 5,620 & 23.9 & 0 \\
\hline Sodium & 149,000 & $\mathrm{Na}^{+}$ & 149,000 & 4.8 & 6,480 \\
\hline Total & & & 350,000 & 7.8 & 6,480 \\
\hline
\end{tabular}

Note:

'The results are from ICP samples prepared by acid digestion.

${ }^{2}$ This result is from ICP samples prepared by fusion. 
Table 5-2. Anion Mass and Charge Data.

\begin{tabular}{|c|c|c|c|c|c|}
\hline \multirow[b]{2}{*}{ Analve } & 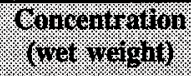 & \multirow{2}{*}{$\begin{array}{l}\text { Assumed } \\
\text { Species }\end{array}$} & $\begin{array}{l}\text { Goncentration of } \\
\text { Assunned Speedes }\end{array}$ & $\begin{array}{l}\text { RSD } \\
\text { (Mean) }\end{array}$ & Ginge \\
\hline & 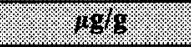 & & 1928 & 9 & years \\
\hline Chloride & 3,460 & $\mathrm{Cl}^{-}$ & 3,460 & 9.5 & 97 \\
\hline Nitrate & 162,000 & $\mathrm{NO}_{3}^{-}$ & 162,000 & 25.1 & 2,610 \\
\hline Nitrite & 49,200 & $\mathrm{NO}_{2}^{-}$ & 49,200 & 8.4 & 1,070 \\
\hline Oxalate & 5,700 & $\mathrm{C}_{2} \mathrm{O}_{4}^{2-}$ & 5,700 & 44.7 & 130 \\
\hline Phosphate & 3,680 & $\mathrm{PO}_{4}{ }^{3-}$ & 3,680 & 56.3 & 116 \\
\hline Sulfate & 7,250 & $\mathrm{SO}_{4}{ }^{2-}$ & 7,250 & 46.1 & 151 \\
\hline $\mathrm{TIC}^{*}$ & $3,760^{1}$ & $\mathrm{CO}_{3}^{2-}$ & 18,800 & 58.3 & 627 \\
\hline TOC** & $1,990^{1}$ & $\mathrm{C}_{2} \mathrm{H}_{3} \mathrm{O}_{2}^{-}$ & 4,890 & 57.3 & 83 \\
\hline Total & & & 255,000 & 16.7 & 4,880 \\
\hline
\end{tabular}

Note:

${ }^{1}$ Results are from core composite data.

Table 5-3. Mass Balance Totals.

\begin{tabular}{|c|c|c|}
\hline & Congenitrations & 195B (Gean) \\
\hline Tolats & 496 & 8 \\
\hline Total from Table $5-1$ & 350,000 & 7.8 \\
\hline Total from Table 5-2 & 255,000 & 16.7 \\
\hline Water \% & 402,000 & 3.5 \\
\hline Grand Total & $1,010,000$ & 5.2 \\
\hline
\end{tabular}

In summary, the above calculations yield reasonable (close to 1.00 for charge balance and 100 percent for mass balance) mass and charge balance values, indicating that the analytical results are generally consistent.

5.1.3.3 Gross Beta and Sum of the Beta Emitters. Limited comparison was made between the gross beta activities with the sum of the individual beta emitters. Selected composite data was available to perform this comparison. Because of the sampling and analytical direction, total alpha, ${ }^{239 / 240} \mathrm{Pu}$ (and other alpha emitters), and total beta measurements were not gathered on each sample. However, some composite results are available. For selected comparisons on the composite level results, see Table 5-4. 
The activities of the individual beta emitters were summed as follows:

$$
\text { Sum of beta emitters }=\left(2 *{ }^{90} \mathrm{Sr}\right)+{ }^{137} \mathrm{Cs}
$$

Because ${ }^{90} \mathrm{Sr}$ is in equilibrium with its daughter product ${ }^{90} \mathrm{Y}$, the radiochemically measured value for ${ }^{90} \mathrm{Sr}$ alone must be multiplied by 2 to obtain numbers comparable with total beta. The slight amount of ${ }^{60} \mathrm{Co}$ detected was considered negligible in this calculation.

Table 5-4. Comparison of Gross Beta Measurements and Individual Beta Emitters.

\begin{tabular}{|c|c|c|c|c|c|}
\hline ogmosing & conocitivalion & 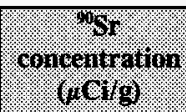 & 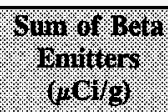 & 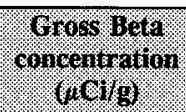 & $(9)$ \\
\hline 138 & 118 & 302 & 722 & 689 & 4.7 \\
\hline 142 & 150 & 203 & 556 & 516 & 7.5 \\
\hline
\end{tabular}

\subsection{COMPARISON OF HISTORICAL WITH ANALYTICAL RESULTS}

Prior to the 1996 sampling event, the most recent sampling of tank 241-S-101 occurred in December 1991. No specific information regarding sample type, sample depth, or number of samples was given. The sample was described as being clear yellow in color did not match the descriptions of the drainable liquid in the 1996 samples, which were given as green and opaque. A comparison between this sampling event and the drainable liquid results from the current sampling event appears in Table 5-5. Only four analytes could be compared.

Aluminum, nitrate, and nitrite results compared well between the two events, while fluoride compared poorly. Due to the differences in physical appearance, this comparison should be used with caution. The results from several pre-1991 sampling events are reported in Appendix $\mathrm{C}$ for informational purposes only.

Table 5-5. Comparison of Data from the 1991 and 1996 Sampling Events. ${ }^{1.2}$

\begin{tabular}{|c|c|c|}
\hline 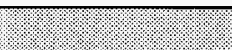 & 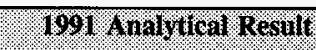 & 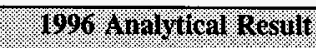 \\
\hline findute & 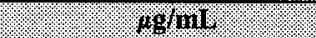 & 48:19i: \\
\hline Aluminum & 15,600 & 24,500 \\
\hline Fluoride & 6,640 & $<106$ \\
\hline Nitrate & $1.97 \mathrm{E}+05$ & $1.81 \mathrm{E}+05$ \\
\hline Nitrite & 96,600 & 94,000 \\
\hline
\end{tabular}

Note:

${ }^{1}$ WHC (1991)

${ }^{2}$ Fritts (1996) 


\subsection{TANK WASTE PROFILE}

According to the estimate of Hanlon (1996), the $413 \mathrm{~cm}$ (163 in.) of waste in tank 241-S-101 was expected to consist of $45 \mathrm{~kL}$ (12 kgal) of supernatant overriding $647 \mathrm{~kL}$ (171 kgal) of saltcake and $924 \mathrm{~kL}$ ( $244 \mathrm{kgal}$ ) of sludge. The saltcake and sludge layers include $318 \mathrm{~kL}$ (84 kgal) of drainable interstitial liquid. This estimate differed from the TLM estimate (Figure 2-3), which divided the waste into $314 \mathrm{~kL}(83 \mathrm{kgal})$ of saltslurry, $799 \mathrm{~kL}$ (211 kgal) of saltcake, and $458 \mathrm{~kL}(121 \mathrm{kgal})$ of sludge.

The visual descriptions of the samples indicated that the segments were similar in texture and color. The predominate colors of the segments were black, gray, and brown, while the texture of the segments varied from wet sludge to damp sludge. The waste descriptions between cores were generally consistent, although drainable liquid was only found in the first three segments of core 138 . The photographic montage of the waste surface showed the waste in the center of the tank to be a dark brown sludge, while the surface around the perimeter of the tank resembled saltcake. Based on the predictions by Hanlon (1996) and the TLM, and the physical descriptions of the segments, the tank waste appears to be somewhat heterogeneous.

\subsubsection{Analysis of Variance Results}

Random effects statistical ANOVA (analysis of variance) models were fit to concentration data from the core/segment samples. The results from these models can be used, on an analyte by analyte basis, to judge the vertical and horizontal variability in mean analyte concentration. Statistical results from these models are univariate results. Multivariate statistical results are outlined in the next section.

Two types of nested random effects ANOVA models were used. One random effects model was fit to core composite data; another was fit to core/segment data. The latter random effects model was fit to three subsets of the data: saltcake data and sludge data, and combined saltcake and sludge data. The ANOVA models were fit to analyte concentration data, provided, at least 50 percent the measurements were above the detection limits. For these analytes, the detection limit was used as the measured concentration. Consequently, the summary statistics for these analytes are biased. The magnitude of the bias cannot be estimated.

For each analyte, estimates of mean concentrations and RSDs of the mean were obtained using restricted maximum likelihood (REML) methods. Appendix A contains the details and the results from the ANOVA. In addition to estimates of the mean and RSDs of the mean, Appendix A contains estimates of the standard deviation of the mean, the upper limit to the one-sided 95 percent confidence intervals on the mean, estimates of the variance components used to measure horizontal and vertical variability and the p-values associated with the F-tests. 
The p-values, associated with the F-tests from the ANOVA, are compared to a standard significance level $(\alpha=0.05)$. If it is less than 0.05 , the analyte means are significantly different from each other. If a p-value is greater than 0.05 , the analyte means are not significantly different from each other. The p-value is used to determine the significance of horizontal and vertical variability within the waste. The results are on an analyte by analyte basis.

The results from the ANOVA were mixed. There were 85 analytes in the sampled solids data. There were significant differences in the mean concentrations between core samples for 1 ( 1 percent) of the analytes and significant differences in mean concentrations between segments for 22 (26 percent) of the analytes. There were significant differences in the mean concentrations between subsegments for 28 (33 percent) of the analytes. This suggests that for the solids, there is vertical variability within the waste, but little evidence of horizontal variability.

For the core composite data ( 84 analytes), there were significant differences in the mean concentrations between core samples for 18 ( 21 percent) of the analytes. That is, based on core composite data, there is horizontal variability within the waste.

For the liquid data (43 analytes), there were significant differences in the mean concentrations between segments for 10 (23 percent) of the analytes. That is, based on core composite data, there is vertical variability within the waste.

The general conclusion from the ANOVA models is that there is vertical variability within the waste. There is marginal evidence for horizontal variability, which can be attributed by simple filling and cascading modelling.

\subsection{COMPARISON OF TRANSFER HISTORY WITH ANALYTICAL RESULTS}

The HTCE prediction for the contents of tank 241-S-101 are shown in Table 5-6 along with the analytical results from the solid portion of the 1996 core sampling event. Because the HTCE has not been validated, the comparison is for information purposes only. These results should be used with caution.

Comparing the HTCE with the analytical values gives varied results. Some analytes are reasonably close in their estimates, while others are very different. Specifically, 12 of 18 comparisons were approximately the same order of magnitude. 
Table 5-6. Comparison of Historical Estimates with the 1996 Analytical Results for Tank 241-S-101, ${ }^{1,2}$ (1 Sheet)

\begin{tabular}{|c|c|c|}
\hline Analyte & MTCE Estimate & $\begin{array}{l}1096 \text { Analytical } \\
\text { Result }\end{array}$ \\
\hline MHTMS : & $10.9 \mathrm{~g} / \mathrm{g}$ & (180 \\
\hline Aluminum & 47,300 & 80,500 \\
\hline Calcium & 2,290 & $329^{3}$ \\
\hline Chromium & 9,130 & 7,250 \\
\hline Iron & 8,860 & 1,360 \\
\hline Manganese & 61.9 & 1,540 \\
\hline Potassium & 797 & $926^{3}$ \\
\hline Sodium & $1.21 \mathrm{E}+05$ & $1.49 \mathrm{E}+05$ \\
\hline Uranium & 4,710 & $4,680^{3}$ \\
\hline ANors: & 1. & 1098. \\
\hline Chloride & 2,840 & 3,460 \\
\hline Nitrate & $1.38 \mathrm{E}+05$ & $1.62 \mathrm{E}+05$ \\
\hline Nitrite & 58,300 & 49,200 \\
\hline Phosphate & 2,390 & 3,680 \\
\hline Sulfate & 7,420 & 7,250 \\
\hline Oxalate & 0.709 & 5,700 \\
\hline Acetate & 124 & $4,890^{4}$ \\
\hline Carbonate & 10,300 & $18,800^{5}$ \\
\hline \multicolumn{3}{|c|}{ 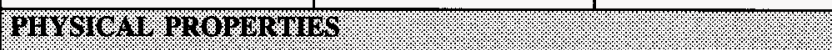 } \\
\hline Bulk Density & $1.49 \mathrm{~g} / \mathrm{mL}$ & $1.65 \mathrm{~g} / \mathrm{mL}$ \\
\hline Water & $45.8 \%$ & $40.2 \%$ \\
\hline
\end{tabular}

Notes:

\footnotetext{
${ }^{1}$ Agnew et al. (1996a)

${ }^{2}$ Fritts (1996)

${ }^{3}$ The results are from samples prepared by acid digestion, while all other metal results are from the fusion digestion data.

${ }^{4}$ Calculated from the core composite results for TOC.

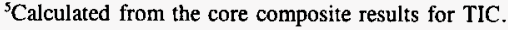




\subsection{EVALUATION OF PROGRAM REQUIREMENTS}

The March and April 1996 core sampling event was governed by two DQOs. The safety screening DQO (Dukelow et al. 1995) is used to assess the safety of the tank waste and to evaluate the tank for placement on a Watch List or to verify current Watch List status. The historical DQO (Simpson and McCain 1995) attempts to acquire information through selective tank sampling to quantify the errors associated with the historical model predictions for the waste composition. A discussion of the specific requirements of these DQOs and a comparison of the analytical results to defined concentration limits is presented in this section. Section 5.5 .1 details the safety evaluations required by the safety screening DQO, while Section 5.5.2 presents the historical model evaluation.5.5.1 Safety Evaluation

\subsubsection{Safety Evaluation}

Data criteria identified in the safety screening DQO are used to identify any unknown safety issues and to evaluate the tank for placement on or removal from a Watch List. Of the five primary analyses required by the DQO, three have decision criteria thresholds which, if exceeded, could warrant further investigation to ensure tank safety. These three analyses include DSC to evaluate fuel content energetics, a determination of total alpha activity to evaluate the criticality potential, and a measurement of the flammability of the tank headspace gases. In addition, the historical DQO required core composite samples to be analyzed for TOC. Table 5-7 lists the applicable safety issues, decision variables and thresholds, and the mean analytical results from the 1996 sampling event.

Table 5-7. Decision Variables and Criteria for the Safety Screening and Historical Data Quality Objectives. (2 sheets)

\begin{tabular}{|c|c|c|c|}
\hline 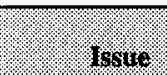 & Prinary boerswa & Decising Gruena & 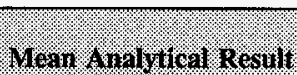 \\
\hline $\begin{array}{l}\text { Ferrocyanide/ } \\
\text { Organics }\end{array}$ & $\begin{array}{l}\text { Total fuel } \\
\text { content/energetics }\end{array}$ & $-480 \mathrm{~J} / \mathrm{g}^{1}$ & $\begin{array}{l}\text { No samples exceeded } \\
\text { limit; highest upper limit } \\
\text { to a one-sided } 95 \text { percent } \\
\text { confidence interval on } \\
\text { the mean }=-226 \mathrm{~J} / \mathrm{g}^{1}\end{array}$ \\
\hline Organic & Total organic carbon & $30,000 \mu \mathrm{g} / \mathrm{g}^{1}$ & $\begin{array}{l}\text { No samples exceeded } \\
\text { limit; highest upper limit } \\
\text { to a one-sided } 95 \text { percent } \\
\text { confidence interval on } \\
\text { the mean = } \\
5,720 \mu \mathrm{g} \mathrm{C} / \mathrm{g}^{1,2}\end{array}$ \\
\hline
\end{tabular}


Table 5-7. Decision Variables and Criteria for the Safety Screening and Historical Data Quality Objectives. (2 sheets)

\begin{tabular}{|c|c|c|c|}
\hline Issue & $\begin{array}{l}\text { Thinar Deeision } \\
\text { Yarable }\end{array}$ & $\begin{array}{l}\text { Decision Griteria } \\
\text { Threshold }\end{array}$ & Miean Aralyilical Resall \\
\hline Criticality & Total alpha activity & $\begin{array}{l}\text { Solids: } \\
34.2 \mu \mathrm{Ci} / \mathrm{g} \\
\text { Liquids: } \\
61.5 \mu \mathrm{Ci} / \mathrm{mL}\end{array}$ & $\begin{array}{l}\text { No samples exceeded } \\
\text { limit; highest upper limit } \\
\text { to a one-sided } \\
\text { confidence interval on } \\
\text { the mean for the solids } \\
\text { was } 2.00 \mu \mathrm{Ci} / \mathrm{g} \text {. } \\
\text { The mean liquid result } \\
\text { was }<0.00810 \mu \mathrm{Ci} / \mathrm{mL}\end{array}$ \\
\hline Flammability & Flammable gas & $25 \%$ of the LFL & $7 \%$ of the $\mathrm{LFL}^{3}$ \\
\hline
\end{tabular}

Note:

\footnotetext{
${ }^{1}$ Value is reported on a dry weight basis.

${ }^{2}$ Result is from the core composite data.

${ }^{3}$ Highest recorded value.
}

The safety screening DQO has established a decision threshold of $-480 \mathrm{~J} / \mathrm{g}$ (dry weight basis) for the DSC analyses; for comparison to this limit, all analytical results were first converted to a dry weight basis. All exothermic results were below the decision threshold, with the highest upper limit to a one-sided 95 percent confidence interval on the mean being $-226 \mathrm{~J} / \mathrm{g}$.

The potential for criticality can be assessed from the total alpha activity data. The safety screening decision threshold is $1 \mathrm{~g} / \mathrm{L}$, which converts to $34.2 \mu \mathrm{Ci} / \mathrm{g}$ for the solids using the highest density of $1.80 \mathrm{~g} / \mathrm{mL}$, or $61.5 \mu \mathrm{Ci} / \mathrm{mL}$ for the liquids. The calculated overall mean for the solids portion of the tank was $0.358 \mu \mathrm{Ci} / \mathrm{g}$, while the overall mean for the liquid portion was $<0.00810 \mu \mathrm{Ci} / \mathrm{mL}$. All results were below the decision threshold, for the solids with the highest upper limit to a one-sided 95 percent confidence interval on the mean being $2.00 \mu \mathrm{Ci} / \mathrm{g}$.

The TOC content of the tank was measured, through the analysis of core composites, as required by the historical DQO. All TOC results were well below the decision threshold of $30,000 \mu \mathrm{g} \mathrm{C} / \mathrm{g}$ (dry weight basis) as outlined in the SAP (Kruger 1996). The overall mean TOC result for the core composites was $3,390 \mu \mathrm{g} \mathrm{C} / \mathrm{g}$, while the highest 95 percent confidence interval upper limit was $5,720 \mu \mathrm{g} \mathrm{C} / \mathrm{g}$.

The flammability of the gas in the tank headspace is an additional safety screening DQO consideration. The notification limit for flammable gas concentration is 25 percent of the LFL. The highest combustible gas meter reading was 7 percent of the LFL. Additional measurements were taken for ammonia $(600 \mathrm{ppm})$, oxygen $(20.8$ percent), and total organic vapor $(31 \mathrm{ppm})$. 
Another factor in assessing tank safety is the heat generation and temperature of the waste. Heat is generated in the tanks from radioactive decay. The total tank heat load estimate from radionuclide data was $5,970 \mathrm{~W}(20,400 \mathrm{Btu} / \mathrm{hr})$ and was calculated as shown in Table 5-8. The HTCE prediction was 5,010 W (17,100 Btu/hr) (Agnew et al. 1996a), while an estimate based on the tank headspace temperature was 4,020 W (13,700 Btu/hr) (Kummerer 1994). All of the estimates are well below the $11,700-\mathrm{W}(40,000-\mathrm{Btu} / \mathrm{hr})$ operating specification limit for single-shell tanks (Bergmann 1991). Because an upper temperature limit has been exhibited (Section 2.4.3), it may be concluded that any heat generated from radioactive sources throughout the year is dissipated.

Table 5-8. Tank 241-S-101 Projected Heat Load.

\begin{tabular}{|l|l|l|l|}
\hline \multicolumn{1}{|c|}{ Radionuclife } & \multicolumn{1}{|c|}{ M Clg } & Qr & Watts \\
\hline${ }^{137} \mathrm{Cs}$ & $131^{1}$ & $3.40 \mathrm{E}+05$ & 1,600 \\
\hline${ }^{8990} \mathrm{Sr}$ & $252^{1}$ & $6.53 \mathrm{E}+05$ & 4,370 \\
\hline Total & & $9.93 \mathrm{E}+05$ & 5,970 \\
\hline
\end{tabular}

Note:

${ }^{\mathrm{I}}$ Mean is from core composite results.

\subsubsection{Historical Model Evaluation}

The primary objective of the historical DQO (Simpson and McCain 1995) is to acquire information through selective tank sampling to quantify the errors associated with predicting tank waste composition based on waste transaction history and waste type compositions. The historical DQO identifies tank $241-\mathrm{S}-101$ as spatially complex in nature. Therefore, because a specific waste type could not be evaluated through segment comparisons, core composites were used to evaluate the HTCE predictions. Core composites are compared to the HTCE predictions in Table 5-9. If the analytical results are $\geq 10$ percent of the HTCE levels (ratio of 0.1 or more), the HTCE predictions are considered acceptable (Simpson and McCain 1995). All of the required comparisons were above the required ratio of 0.1 , indicating that, at this level of evaluation, the HTCE predictions are valid. Interesting to note is the oxalate ratio. It has been observed that acetate, EDTA, HEDTA, and citrate contribute to the energetics of the waste. Oxalate has been proposed as a decomposition product from aging of some of the organic forms in the waste. 
Table 5-9. Comparison of Historical Tank Content Estimates with Mean Core Composite Results from Tank 241-S-101. ${ }^{1,2}$

\begin{tabular}{|c|c|c|c|}
\hline Analute & $\begin{array}{l}\text { Meari Gore } \\
\text { Composite Result }\end{array}$ & mCE Estinate & \\
\hline WETMS & . $10 / \mathrm{g}$ & $10.9 \mathrm{e}$ & (2.1io \\
\hline Aluminum & 88,900 & 47,300 & 1.88 \\
\hline Calcium & $435^{3}$ & 2,290 & 0.190 \\
\hline Chromium & 5,230 & 9,130 & 0.573 \\
\hline Iron & 1,200 & 8,860 & 0.135 \\
\hline Manganese & 1,700 & 61.9 & 27.5 \\
\hline Nickel & 3,350 & 665 & 5.04 \\
\hline Potassium & $880^{3}$ & 797 & 1.10 \\
\hline Silicon & 2,350 & 1,220 & 1.93 \\
\hline Sodium & $1.91 \mathrm{E}+05$ & $1.21 \mathrm{E}+05$ & 1.58 \\
\hline Uranium & $5,190^{3}$ & 4,710 & 1.10 \\
\hline GNTOW: & (3.) & thes & Rafo: \\
\hline Chloride & 3,260 & 2,840 & 1.15 \\
\hline Nitrate & $1.35 \mathrm{E}+05$ & $1.38 \mathrm{E}+05$ & 0.978 \\
\hline Nitrite & 45,000 & 58,300 & 0.772 \\
\hline Phosphate & 4,020 & 2,390 & 1.68 \\
\hline Sulfate & 6,270 & 7,420 & 0.845 \\
\hline Oxalate & 3,940 & 0.709 & 5,560 \\
\hline Acetate & $4,890^{4}$ & 124 & 39.4 \\
\hline Carbonate & $18,800^{5}$ & 10,300 & 1.83 \\
\hline PIMSTCAY PROPRRTIES & $\begin{array}{l}\text { Mean Core } \\
\text { Composite Result }\end{array}$ & III CE Is Itimate & Ratio \\
\hline Bulk Density & $1.65 \mathrm{~g} / \mathrm{mL}$ & $1.49 \mathrm{~g} / \mathrm{mL}$ & 1.11 \\
\hline Water & $38.4 \%$ & $45.8 \%$ & 0.838 \\
\hline
\end{tabular}

Notes:

'Agnew et al. (1996a)

${ }^{2}$ Fritts (1996)

${ }^{3}$ Results are from samples prepared by acid digestion, while the remaining metals were prepared by the fusion method.

${ }^{4}$ Calculated from TOC.

${ }^{5}$ Calculated from TIC. 
WHC-SD-WM-ER-613 Rev. 0

This page intentionally left blank. 


\subsection{CONCLUSIONS AND RECOMMENDATIONS}

The waste in tank 241-S-101 was core sampled in March/April 1996 in accordance with Tank Safety Screening Data Quality Objective (Dukelow et al. 1995), Historical Model Evaluation Data Requirements (Simpson and McCain 1995), and Strategy for Sampling Hanford Site Tank Wastes for Development of Disposal Technology (Kupfer et al. 1995). This sampling effort involved taking push-mode core samples of the tank waste from three different risers. The sampling and analyses were performed in accordance with Tank 241-S-101 Push Mode Core Sampling and Analysis Plan (Kruger 1996). All analyses on core 138 and core 142 were performed at the Westinghouse Hanford Company 222-S Laboratory. Samples from core 137 were composited and a subsample sent to the Pretreatment Program to fulfill the SAP requirements.

Comparisons were made between the analytical results and the decision thresholds given in the DQOs. The safety screening DQO has established a decision threshold on exotherms of $-480 \mathrm{~J} / \mathrm{g}$ (dry weight basis) for the DSC analyses; for comparison to this limit, all analytical results were first converted to a dry weight basis. All exothermic results were below the decision threshold, with the highest upper limit to a one-sided 95 percent confidence interval on the mean being $-226 \mathrm{~J} / \mathrm{g}$. All of the TOC results were below the decision limit of $30,000 \mu \mathrm{g} \mathrm{C} / \mathrm{g}$ (dry weight basis). The overall mean TOC result for the core composites was $3,390 \mu \mathrm{g} \mathrm{C} / \mathrm{g}$, while the highest upper limit to a one-sided 95 percent confidence interval on the mean was $5,720 \mu \mathrm{g} \mathrm{C} / \mathrm{g}$. The overall solids mean for total alpha activity was $0.358 \mu \mathrm{Ci} / \mathrm{g}$, while the overall liquid mean was $<0.00810 \mu \mathrm{Ci} / \mathrm{mL}$. All results were below the decision threshold ( $34.2 \mu \mathrm{Ci} / \mathrm{g}$ for the solids and $61.5 \mu \mathrm{Ci} / \mathrm{mL}$ for the liquids), with the highest upper limit to a one-sided 95 percent confidence interval on the mean for the solids being $2.00 \mu \mathrm{Ci} / \mathrm{g}$. Finally, the highest flammable gas reading in the tank headspace was 7 percent of the LFL.

The total tank heat load estimate from radionuclide data was $5,970 \mathrm{~W}(20,400 \mathrm{Btu} / \mathrm{hr})$. The HTCE prediction was 5,010 W (17,100 Btu/hr) (Agnew et al. 1996a), while an estimate based on the tank headspace temperature was 4,020 W (13,700 Btu/hr) (Kummerer 1994). All estimates are very similar and comparable, and well below the $11,700 \mathrm{~W}(40,000 \mathrm{Btu} / \mathrm{hr})$ operating specification limit for single-shell tanks (Bergmann 1991). Because the tank exhibits an upper temperature limit, it may be concluded that any heat generated from radioactive sources throughout the year is dissipated.

Finally, several conclusions were drawn from the analytical results. Based on the decision criteria of the safety screening DQO, this tank may be categorized as "safe." The waste in tank 241-S-101 may continue to be safely stored in the tank without special action. There were no unexpected findings that could affect the ability to retrieve and dispose of the waste safely. In addition, no further characterization efforts are needed at this time. 
WHC-SD-WM-ER-613 Rev. 0

This page intentionally left blank. 


\subsection{REFERENCES}

Agnew, S. F., J. Boyer, R. Corbin, T. Duran, J. Fitzpatrick, K. Jurgensen, T. Ortiz, and B. Young, 1996a, Hanford Tank Chemical and Radionuclide Inventories: HDW Model Rev. 3, LA-UR-96-858, Rev. 0, Los Alamos National Laboratory, Los Alamos, New Mexico.

Agnew, S. F., P. Baca, R. Corbin, T. Duran, and K. Jurgensen, 1996b, Waste Status and Transaction Record Summary for the Southwest Quadrant, WHC-SD-WM-TI-614, Rev. 2, Westinghouse Hanford Company, Richland, Washington.

Alstad, A. T., 1993, Riser Configuration Document for Single-Shell Waste Tanks, WHC-SD-RE-TI-053, Rev. 9, Westinghouse Hanford Company, Richland, Washington.

ARHCO, 1975, 101-S Tank Arrangement As Built, Drawing H-2-37524, Rev. 0, Atlantic Richfield Hanford Company, Richland, Washington.

Bergmann, L. M., 1991, Single-Shell Tank Isolation Safety Analysis Report, WHC-SD-WM-SAR-006, Rev, 2, Westinghouse Hanford Company, Richland, Washington.

Brevick, C. H., L. Gaddis, and A. Walsh, 1994, Supporting Document for the Historical Tank Content Estimate for S Tank Farm, WHC-SD-WM-ER-323, Rev. 0, Westinghouse Hanford Company, Richland, Washington.

De Lorenzo, D. S., A. T. DiCenso, D. B. Hiller, K. W. Johnson, J. H. Rutherford, D. J. Smith, and B. C. Simpson, 1994, Tank Characterization Reference Guide, WHC-SD-WM-TI-648, Rev. 0, Westinghouse Hanford Company, Richland, Washington.

Dukelow, G. T., J. W. Hunt, H. Babad, and J. E. Meacham, 1995, Tank Safety Screening Data Quality Objective, WHC-SD-WM-SP-004, Rev. 2, Westinghouse Hanford Company, Richland, Washington.

Ecology, EPA, and DOE, 1996, Hanford Federal Facility Agreement and Consent Order, as amended, Washington State Department of Ecology, U.S. Environmental Protection Agency, and U.S. Department of Energy, Olympia, Washington.

Fritts, L. L., 1996, Final Results for Tank 241-S-101, Push Mode Cores 137, 138, and 142, WHC-SD-WM-DP-185, Rev. 0, Westinghouse Hanford Company, Richland, Washington. 
Hanlon, B. M., 1996, Waste Tank Summary Report for Month Ending April 30, 1996, WHC-EP-0182-97, Westinghouse Hanford Company, Richland, Washington.

Horton, J. E., 1975, Analysis and Characterization of Sludge from Tank 101-S, (internal letter to W. R. Christensen, July 16), Atlantic Richfield Hanford Company, Richland, Washington.

Kruger, A. A., 1996, Tank 241-S-101 Push Mode Core Sampling and Analysis Plan, WHC-SD-WM-TSAP-078, Rev. 0A, Westinghouse Hanford Company, Richland, Washington.

Kummerer, M., 1994, Topical Report on Heat Removal Characteristics of Waste Storage Tanks, WHC-SD-WM-SARR-010, Rev. 0, Westinghouse Hanford Company, Richland, Washington.

Kupfer, M. J., W. Schulz, and J. Slankas, 1995, Strategy for Sampling Hanford Site Tank Wastes for Development of Disposal Technology, WHC-SD-WM-TA-154, Rev. 1, Westinghouse Hanford Company, Richland, Washington.

Leach, C. E., and S. Stahl, 1996, Hanford Site Tank Farm Facilities Interim Safety Basis, WHC-SD-WM-ISB-001, Rev. 0A, Westinghouse Hanford Company, Richland, Washington.

Lipnicki, J., 1996, Waste Tank Risers Available for Sampling, WHC-SD-WM-TI-710, Rev. 3, Westinghouse Hanford Company, Richland, Washington.

NFPA, 1995, National Fire Codes, Vol. 10, Section 115, "Laser Fire Protection", National Fire Protection Association, Quincy, Massachusetts.

Nuclear Regulatory Commission, 1988, Statistical Methods for Nuclear Materials Management, NUREG-CR-4604, PNL-5849, (C. A. Bennett and W. M. Bowen eds.), U.S. Government Printing Office, Washington, D.C.

Puryear, D. A., 1971, Characterization of $S, U$, and SX Waste Tanks, (internal letter to J. O. Skolrud, September 21), Atlantic Richfield Hanford Company, Richland, Washington.

Rutherford, M. J., 1949, Specifications for Construction of Waste Disposal Facilities, 241-S, 216-S, 207-S, 200 West Area, Hanford Works, Specification No. HW 3937, General Electric Company, Richland, Washington.

Simpson, B. C., and D. McCain, 1995, Historical Model Evaluation Data Requirements, WHC-SD-WM-DQO-018, Rev. 0, Westinghouse Hanford Company, Richland, Washington. 
Tran, T. T., 1993, Thermocouple Status Single Shell \& Double Shell Waste Tanks, WHC-SD-WM-TI-553, Rev. 0, Westinghouse Hanford Company, Richland, Washington.

Vitro Engineering Corporation, 1980, Piping Waste Tank Isolation TK-241-S-101, Drawing H-2-73181, Rev. 0, Vitro Engineering Corporation, Richland, Washington.

WHC, 1991, Sample Status Report for T-8579, December 30, Tank Characterization Resource Center, Tank S-101, Item 6, Westinghouse Hanford Company, Richland, Washington.

WHC, 1996, SACS: Surveillance Analysis Computer System, In: SYBASE/Visual Basic [Mainframe], Available: Hanford Local Area Network (HLAN), Westinghouse Hanford Company, Richland, Washington; or Tank Waste Information Network System (TWINS), Battelle - Pacific Northwest National Laboratory.

Wheeler, R. E., 1974, Analysis of Tank Farm Samples, Sample T8084, Tank 101-S, (internal letter to R. L. Walser, December 20), Atlantic Richfield Hanford Company, Richland, Washington.

Wheeler, R. E., 1975, Analysis of Tank Farm Samples, Sample T9715, Tank 101-S, (internal letter to R. L. Walser, December 5), Atlantic Richfield Hanford Company, Richland, Washington. 
WHC-SD-WM-ER-613 Rev. 0

This page intentionally left blank. 
WHC-SD-WM-ER-613 Rev. 0

\section{APPENDIX A}

\section{ANALYTICAL RESULTS FROM 1996 CORE SAMPLING}


WHC-SD-WM-ER-613 Rev. 0

This page intentionally left blank.

A-2 


\section{A.0 ANALYTICAL RESULTS FROM 1996 CORE SAMPLING AND 1995 GRAB SAMPLING}

\section{A.1 INTRODUCTION}

Appendix A reports the chemical, radiochemical and physical characteristics of tank 241-S-101 in table form and in terms of the specific concentrations of metals, ions, radionuclides, and physical properties.

Each data table lists the following: laboratory sample identification, sample origin (core/segment/subsegment), an original and duplicate result for each sample, a sample mean, an overall mean for the tank, an RSD (mean), and a projected tank inventory for the particular analyte using the weighted mean and the appropriate conversion factors. Projected tank inventory is not applicable to the percent water, DSC, or density data. The data are listed in standard notation for values greater than 0.001 and less than 100,000 . Values outside these limits are listed in scientific notation.

The tables are numbered A-1 through A-58. A description of the units and symbols used in the analyte tables and the references used in compiling the analytical data (Fritts 1996) are found in the List of Terms and Section 7.0, respectively. For a description of the sampling event and information on sampling rationale and locations, see Section 3.0.

\section{A.2 ANALYTE TABLE DESCRIPTION}

The "Sample Number" column lists the laboratory sample for which the analyte was measured.

The "Core:Segment" column specifies the core and segment from which each sample was derived.

The "Subsegment" column specifies the segment portion (subsegment) from which the sample was taken. This can be the entire segment (whole), the drainable liquid portion (DL), upper or lower half segment portions, or quarter segment portions (A refers to top quarter, B refers to second quarter).

The "Result" and "Duplicate" columns are self-explanatory. The "Sample Mean" column lists the average of the result and duplicate values. If the result and duplicate values were both detected, or one of the two values is detected and the other non-detected, then the mean is expressed as a detected value. If the result and duplicate values were both nondetected, then the mean is expressed as a nondetected. The result and duplicate values, as well as the result/duplicate means, are reported in the tables exactly as found in the original laboratory data package. The means may appear to have been rounded up in some cases and rounded down in others. This is because the analytical results given in the tables may have fewer 
significant figures than originally reported, not because the means were incorrectly calculated.

The overall (or analyte concentration) means for the waste in tank 241-S-101 were calculated as follows:

The individual sample result and duplicate pairs were first averaged to obtain a sample mean. Sample means from the same segment were then averaged to obtain a segment mean, the segment means within a given core were averaged to obtain a core mean, and finally the core means were averaged to obtain the overall mean. As a note, not all of these steps were necessary for each analyte or for each subsegment, but the procedure to be followed is the same. All values, including those below the detection level (indicated by the less-than symbol, "<"), were utilized in calculating the overall means. If 50 percent or more of all the individual sample and duplicate results were detected, then the overall mean was expressed as a detected value. If less than 50 percent of all the individual results were detected, then the overall mean was expressed as a nondetected value. When nondetected values are used as qualitative results the mean concentration and inventory estimates are biased. The magnitude of the bias cannot be determined, but the bias is to more conservative concentration estimates.

The RSD (mean) was computed for applicable analytes using standard ANOVA statistical techniques. Relative standard deviations (of the mean) were calculated for all analytes with "detected" means, including those analytes which contained some nondetected results. Using nondetected results in the mean calculations also required their use in the RSD (mean) calculations. Whereas the use of nondetected results in mean calculations produces a known high bias, using these values in statistical calculations creates an unknown bias. Thus, the RSD (mean) estimates and the ANOVA values in which nondetected results were used should be interpreted with caution.

The "Projected Inventory" is the product of the overall analyte concentration mean, the volume of tank waste $(1,571 \mathrm{~kL}$ for the solids and $45 \mathrm{~kL}$ for the liquids), the density, where applicable ( $1.65 \mathrm{~mL}$ for the solids), and the appropriate conversion factors.

The four quality control parameters assessed on the tank 241-S-101 samples were standard recoveries, spike recoveries, duplicate analyses (RPDs), and blanks. These were summarized in Section 5.1.2. More specific information is provided in the following appendix tables. Sample and duplicate pairs in which any of the QC parameters were outside their specified limits are superscripted in the "Sample Mean" column as follows:

QC:a -- indicates that the standard recovery was below the QC range.

$\mathrm{QC}: \mathrm{b}$-- indicates that the standard recovery was above the QC range.

$\mathrm{QC}: \mathrm{c}$-- indicates that the spike recovery was below the QC range.

$\mathrm{QC}: \mathrm{d}$-- indicates that the spike recovery was above the QC range.

QC: :- indicates that the RPD was greater than the QC limit range.

QC:f -- indicates blank contamination. 
Table A-1. Tank 241-S-101 Analytical Results: Aluminum. (4 sheets)

\begin{tabular}{|c|c|c|c|c|c|c|c|c|}
\hline Manpor & ogonoril & Sognent & Rerul & Fingligale & $1 \%$ (1) & hopall & 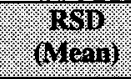 & Grougeter \\
\hline \multicolumn{2}{|c|}{ 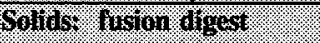 } & (3) & $14 \% 8$ & WO/ & W\% & 1986. & $8 \%$ & 83 \\
\hline S96T001903 & 138: $2 \mathrm{R} 1$ & Lower $1 / 2$ & 19,600 & 23,500 & 21,550 & \multirow[t]{21}{*}{80,500} & \multirow[t]{21}{*}{14.7} & \multirow[t]{21}{*}{$2.09 \mathrm{E}+05$} \\
\hline S96T002040 & 138: $3 \mathrm{AR}$ & Whole & 29,900 & 30,300 & 30,100 & & & \\
\hline S96T001891 & \multirow[t]{2}{*}{ 138: 5} & Upper $1 / 2$ & 96,400 & 92,900 & 94,650 & & & \\
\hline S96T001902 & & Lower $1 / 2$ & $1.060 \mathrm{E}+05$ & $1.080 \mathrm{E}+05$ & $1.070 \mathrm{E}+05$ & & & \\
\hline S96T002045 & \multirow[t]{2}{*}{ 138: 6} & Upper $1 / 2$ & 97,100 & 94,900 & 96,000 & & & \\
\hline S96T002047 & & Lower $1 / 2$ & 85,100 & $1.060 \mathrm{E}+05$ & $95,550^{\mathrm{QC}: \mathrm{e}}$ & & & \\
\hline S96T002193 & \multirow[t]{2}{*}{ 138: 7} & Upper $1 / 2$ & $1.070 \mathrm{E}+05$ & $1.090 \mathrm{E}+05$ & $1.080 \mathrm{E}+05$ & & & \\
\hline S96T002202 & & Lower $1 / 2$ & $1.190 \mathrm{E}+05$ & $1.180 \mathrm{E}+05$ & $1.185 \mathrm{E}+05$ & & & \\
\hline S96T002046 & \multirow[t]{2}{*}{ 138: 8} & Upper $1 / 2$ & $1.210 \mathrm{E}+05$ & $1.210 \mathrm{E}+05$ & $1.210 \mathrm{E}+05$ & & & \\
\hline S96T002048 & & Lower $1 / 2$ & $1.280 \mathrm{E}+05$ & $1.300 \mathrm{E}+05$ & $1.290 \mathrm{E}+05$ & & & \\
\hline S96T002194 & \multirow[t]{2}{*}{ 138: 9} & Upper $1 / 2$ & $1.330 \mathrm{E}+05$ & $1.330 \mathrm{E}+05$ & $1.330 \mathrm{E}+05$ & & & \\
\hline S96T002199 & & Lower $1 / 2$ & $1.200 \mathrm{E}+05$ & $1.160 \mathrm{E}+05$ & $1.180 \mathrm{E}+05$ & & & \\
\hline S96T002090 & $142: 1$ & Upper $1 / 2$ & 20,500 & 20,300 & 20,400 & & & \\
\hline S96T002310 & \multirow[t]{2}{*}{$142: 2$} & Upper $1 / 2$ & 20,500 & 20,100 & 20,300 & & & \\
\hline S96T002316 & & Lower $1 / 2$ & 24,000 & 23,600 & 23,800 & & & \\
\hline S96T002311 & \multirow[t]{2}{*}{$142: 3$} & Upper $1 / 2$ & 22,900 & 22,800 & 22,850 & & & \\
\hline S96T002319 & & Lower $1 / 2$ & 24,100 & 23,900 & 24,000 & & & \\
\hline \$96T002092 & \multirow[t]{2}{*}{$142: 4$} & Upper $1 / 2$ & 30,100 & 23,900 & $27,000^{\mathrm{QC}: \mathrm{e}}$ & & & \\
\hline S96T002105 & & Lower $1 / 2$ & 74,200 & 65,600 & 69,900 & & & \\
\hline S96T002093 & \multirow[t]{2}{*}{$142: 5$} & Upper 1/2 & $1.110 \mathrm{E}+05$ & $1.050 \mathrm{E}+05$ & $1.080 \mathrm{E}+05$ & & & \\
\hline S96T002106 & & Lower $1 / 2$ & $1.230 \mathrm{E}+05$ & $1.000 \mathrm{E}+05$ & $1.115 \mathrm{E}+05$ & & & \\
\hline
\end{tabular}


Table A-1. Tank 241-S-101 Analytical Results: Aluminum. (4 sheets)

\begin{tabular}{|c|c|c|c|c|c|c|c|c|}
\hline Whares & (6) & 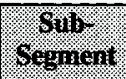 & gesiol & Ouglonge & Sompon & 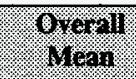 & 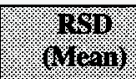 & Wrosichor \\
\hline \multicolumn{3}{|c|}{ 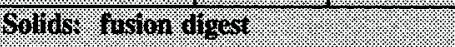 } & 120 & 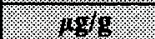 & 61868 & $\% \psi$ & $8 \%$ & 1.68 \\
\hline S96T002094 & \multirow[t]{2}{*}{$142: 6$} & Upper $1 / 2$ & $1.050 \mathrm{E}+05$ & $1.020 \mathrm{E}+05$ & $1.035 \mathrm{E}+05$ & \multirow[t]{6}{*}{ Cont. } & \multirow[t]{6}{*}{ Cont. } & \multirow[t]{6}{*}{ Cont. } \\
\hline S96T002091 & & Lower $1 / 2$ & $1.020 \mathrm{E}+05$ & $1.130 \mathrm{E}+05$ & $1.075 \mathrm{E}+05$ & & & \\
\hline S96T002095 & \multirow[t]{2}{*}{$142: 7$} & Upper $1 / 2$ & $1.100 \mathrm{E}+05$ & $1.130 \mathrm{E}+05$ & $1.115 \mathrm{E}+05$ & & & \\
\hline S96T002107 & & Lower $1 / 2$ & $1.280 \mathrm{E}+05$ & $1.300 \mathrm{E}+05$ & $1.290 \mathrm{E}+05$ & & & \\
\hline S96T002096 & \multirow[t]{2}{*}{ 142: 8} & Upper $1 / 2$ & $1.470 \mathrm{E}+05$ & $1.450 \mathrm{E}+05$ & $1.460 \mathrm{E}+05$ & & & \\
\hline S96T002108 & & Lower $1 / 2$ & $1.250 \mathrm{E}+05$ & $1.350 \mathrm{E}+05$ & $1.300 \mathrm{E}+05$ & & & \\
\hline \multicolumn{3}{|c|}{ Solfis. uquldigeot } & 1.496. & $488 \mathrm{~g}$ & $10 \mathrm{~g} \%$ & $108 \%$ & $\%$ & 48 \\
\hline S96T001905 & 138: 2R1 & Lower $1 / 2$ & 17,200 & 17,500 & 17,350 & \multirow[t]{14}{*}{21,000} & \multirow[t]{14}{*}{6.9} & \multirow[t]{14}{*}{54,400} \\
\hline S96T001892 & \multirow[t]{2}{*}{$138: 5$} & Upper $1 / 2$ & 20,600 & 21,800 & 21,200 & & & \\
\hline S96T001904 & & Lower $1 / 2$ & 15,900 & 17,500 & 16,700 & & & \\
\hline S96T002049 & \multirow[t]{2}{*}{ 138: 6} & Upper $1 / 2$ & 20,600 & 17,200 & 18,900 & & & \\
\hline S96T002050 & & Lower $1 / 2$ & 16,800 & 15,200 & 16,000 & & & \\
\hline S96T002195 & \multirow[t]{2}{*}{ 138: 7} & Upper $1 / 2$ & 21,100 & 16,300 & $18,700^{\mathrm{QC}: \mathrm{e}}$ & & & \\
\hline S96T002203 & & Lower $1 / 2$ & 18,100 & 24,100 & $21,100^{\mathrm{QC}: \mathrm{e}}$ & & & \\
\hline S96T002051 & \multirow[t]{2}{*}{$138: 8$} & Upper $1 / 2$ & 20,700 & 23,400 & 22,050 & & & \\
\hline S96T002052 & & Lower $1 / 2$ & 25,000 & 23,600 & 24,300 & & & \\
\hline S96T002196 & \multirow[t]{2}{*}{ 138: 9} & Upper $1 / 2$ & 39,300 & 25,800 & $32,550^{\mathrm{QC}: \mathrm{e}}$ & & & \\
\hline S96T002200 & & Lower $1 / 2$ & 16,800 & 16,500 & 16,650 & & & \\
\hline S96T002097 & 142: 1 & Upper $1 / 2$ & 16,800 & 16,700 & 16,750 & & & \\
\hline S96T002312 & \multirow[t]{2}{*}{$142: 2$} & Upper $1 / 2$ & 17,500 & 15,200 & 16,350 & & & \\
\hline S96T002317 & & Lower $1 / 2$ & 17,700 & 17,500 & 17,600 & & & \\
\hline
\end{tabular}


Table A-1. Tank 241-S-101 Analytical Results: Aluminum. (4 sheets)

\begin{tabular}{|c|c|c|c|c|c|c|c|c|}
\hline 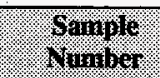 & \%orot & 6415) & Resill & buplopate & 9.8101\% & Weral & (1015) & Woutrou \\
\hline \multicolumn{3}{|c|}{ 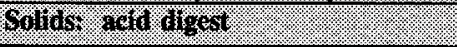 } & 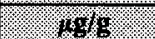 & 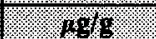 & $10 \%$ & $1.18 \%$ & W. & (6) \\
\hline S96T002313 & \multirow[t]{2}{*}{$142: 3$} & Upper $1 / 2$ & 15,500 & 19,300 & $17,400^{\mathrm{QC}: \mathrm{e}}$ & \multirow[t]{12}{*}{ Cont. } & \multirow[t]{12}{*}{ Cont. } & \multirow[t]{12}{*}{ Cont. } \\
\hline S96T002320 & & Lower $1 / 2$ & 18,900 & 18,900 & 18,900 & & & \\
\hline S96T002109 & \multirow[t]{2}{*}{ 142: 4} & Upper $1 / 2$ & 17,800 & 17,700 & 17,750 & & & \\
\hline S96T002110 & & Lower $1 / 2$ & 21,000 & 21,500 & 21,250 & & & \\
\hline S96T002111 & \multirow[t]{2}{*}{$142: 5$} & Upper $1 / 2$ & 17,600 & 19,700 & 18,650 & & & \\
\hline S96T002112 & & Lower $1 / 2$ & 15,100 & 18,600 & 16,850 & & & \\
\hline \$96T002113 & \multirow[t]{2}{*}{$142: 6$} & Upper $1 / 2$ & 17,000 & 19,700 & 18,350 & & & \\
\hline S96T002098 & & Lower $1 / 2$ & 25,500 & 78,500 & $52,000^{\mathrm{QC}: e}$ & & & \\
\hline S96T002114 & \multirow[t]{2}{*}{ 142: 7} & Upper $1 / 2$ & 14,200 & 21,300 & $17,750^{\mathrm{QC}: \mathrm{e}}$ & & & \\
\hline S96T002115 & & Lower $1 / 2$ & 28,100 & 22,400 & $25,250^{\mathrm{QC}: e}$ & & & \\
\hline S96T002116 & \multirow[t]{2}{*}{$142: 8$} & Upper $1 / 2$ & 32,100 & 27,600 & 29,850 & & & \\
\hline S96T002117 & & Lower $1 / 2$ & 22,800 & 28,300 & $25,550^{\mathrm{QC}: \mathrm{e}}$ & & & \\
\hline \multicolumn{3}{|c|}{ 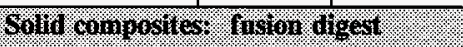 } & .1498 & $4.108 \%$ & 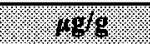 & 998 & $16 \%$ & 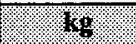 \\
\hline S96T002723 & 138 & N/A & $1.070 \mathrm{E}+05$ & $1.050 \mathrm{E}+05$ & $1.060 \mathrm{E}+05$ & \multirow[t]{2}{*}{88,900} & \multirow[t]{2}{*}{19.3} & \multirow[t]{2}{*}{$2.30 \mathrm{E}+05$} \\
\hline S96T002731 & 142 & N/A & 69,600 & 73,800 & 71,700 & & & \\
\hline \multicolumn{3}{|c|}{ 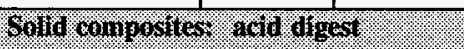 } & $1.81 \mathrm{~g}$ & 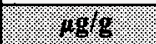 & $6 \mathrm{~g} / \mathrm{s}$ & 148 & $\%$ & 89 \\
\hline S96T002724 & 138 & N/A & 22,600 & 21,200 & 21,900 & \multirow[t]{2}{*}{23,900} & \multirow[t]{2}{*}{8.3} & \multirow[t]{2}{*}{62,000} \\
\hline S96T002733 & 142 & N/A & 28,400 & 23,300 & 25,850 & & & \\
\hline \multicolumn{3}{|c|}{ 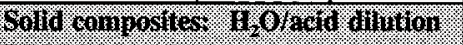 } & 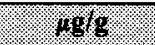 & 48 & 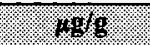 & 1096 & $\%$ & 6 \\
\hline S96T002726 & 138 & N/A & 12,900 & 11,700 & 12,300 & \multirow[t]{2}{*}{11,800} & \multirow[t]{2}{*}{8.7} & \multirow[t]{2}{*}{30,600} \\
\hline S96T002736 & 142 & N/A & 13,600 & 8,940 & $11,270^{\mathrm{QC}: \mathrm{e}}$ & & & \\
\hline
\end{tabular}




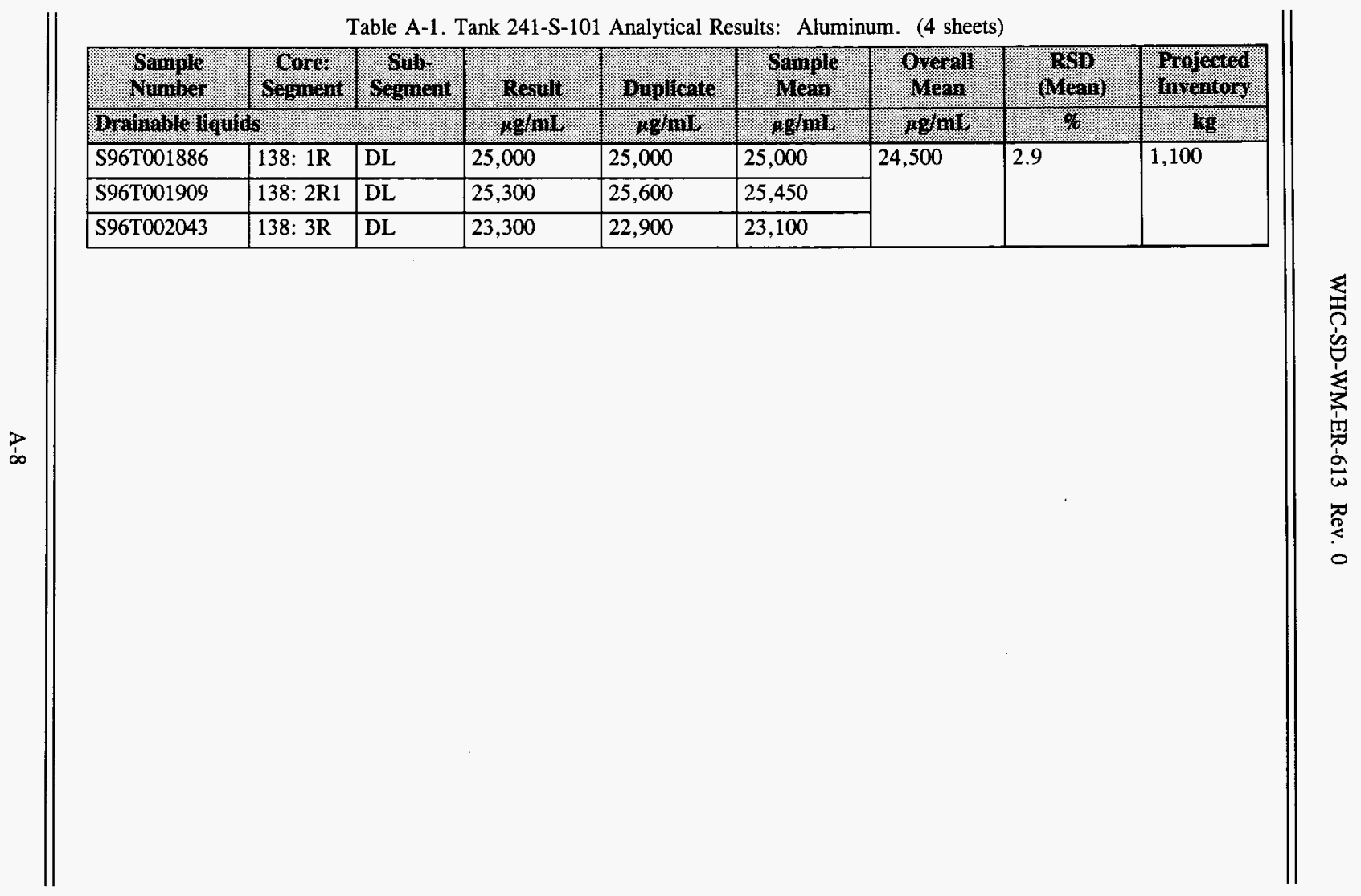


Table A-2. Tank 241-S-101 Analytical Results: Antimony. (4 sheets)

\begin{tabular}{|c|c|c|c|c|c|c|c|c|}
\hline Worpo & octorent & \%ormon & Mcruit & Buplisate & ominu & Whon & (1) & Mors \\
\hline \multicolumn{3}{|c|}{ 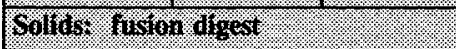 } & 1819 & $160 \%$ & 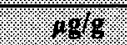 & 1698 & 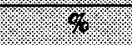 & 46 \\
\hline S96T001903 & 138: 2R1 & Lower $1 / 2$ & $<1,180$ & $<1,120$ & $<1,150$ & \multirow[t]{19}{*}{$<1,200$} & \multirow[t]{19}{*}{ N/A } & \multirow[t]{19}{*}{$<3,110$} \\
\hline S96T002040 & 138: $3 \mathrm{AR}$ & Whole & $<1,220$ & $<1,140$ & $<1,180$ & & & \\
\hline S96T001891 & \multirow[t]{2}{*}{$138: 5$} & Upper $1 / 2$ & $<1,260$ & $<1,270$ & $<1,265$ & & & \\
\hline S96T001902 & & Lower $1 / 2$ & $<1,090$ & $<1,060$ & $<1,075$ & & & \\
\hline S96T002045 & \multirow[t]{2}{*}{ 138: 6} & Upper $1 / 2$ & $<1,150$ & $<1,130$ & $<1,140$ & & & \\
\hline S96T002047 & & Lower $1 / 2$ & $<1,240$ & $<1,140$ & $<1,190$ & & & \\
\hline \$96T002193 & \multirow[t]{2}{*}{ 138: 7} & Upper $1 / 2$ & $<1,250$ & $<1,270$ & $<1,260$ & & & \\
\hline S96T002202 & & Lower $1 / 2$ & $<1,200$ & $<1,200$ & $<1,200$ & & & \\
\hline S96T002046 & \multirow[t]{2}{*}{ 138: 8} & Upper $1 / 2$ & $<1,230$ & $<1,250$ & $<1,240$ & & & \\
\hline S96T002048 & & Lower $1 / 2$ & $<1,130$ & $<1,220$ & $<1,175$ & & & \\
\hline S96T002194 & \multirow[t]{2}{*}{ 138: 9} & Upper $1 / 2$ & $<1,160$ & $<1,230$ & $<1,195$ & & & \\
\hline S96T002199 & & Lower $1 / 2$ & $<1,280$ & $<1,250$ & $<1,265$ & & & \\
\hline S96T002090 & $142: 1$ & Upper $1 / 2$ & $<1,230$ & $<1,230$ & $<1,230$ & & & \\
\hline S96T002310 & \multirow[t]{2}{*}{$142: 2$} & Upper $1 / 2$ & $<1,130$ & $<1,110$ & $<1,120$ & & & \\
\hline S96T002316 & & Lower $1 / 2$ & $<1,220$ & $<1,220$ & $<1,220$ & & & \\
\hline S96T002311 & \multirow[t]{2}{*}{$142: 3$} & Upper $1 / 2$ & $<1,210$ & $<1,230$ & $<1,220$ & & & \\
\hline S96T002319 & & Lower $1 / 2$ & $<1,170$ & $<1,140$ & $<1,155$ & & & \\
\hline S96T002092 & \multirow[t]{2}{*}{$142: 4$} & Upper $1 / 2$ & $<1,210$ & $<1,200$ & $<1,205$ & & & \\
\hline S96T002105 & & Lower $1 / 2$ & $<1,200$ & $<1,240$ & $<1,220$ & & & \\
\hline
\end{tabular}


Table A-2. Tank 241-S-101 Analytical Results: Antimony. (4 sheets)

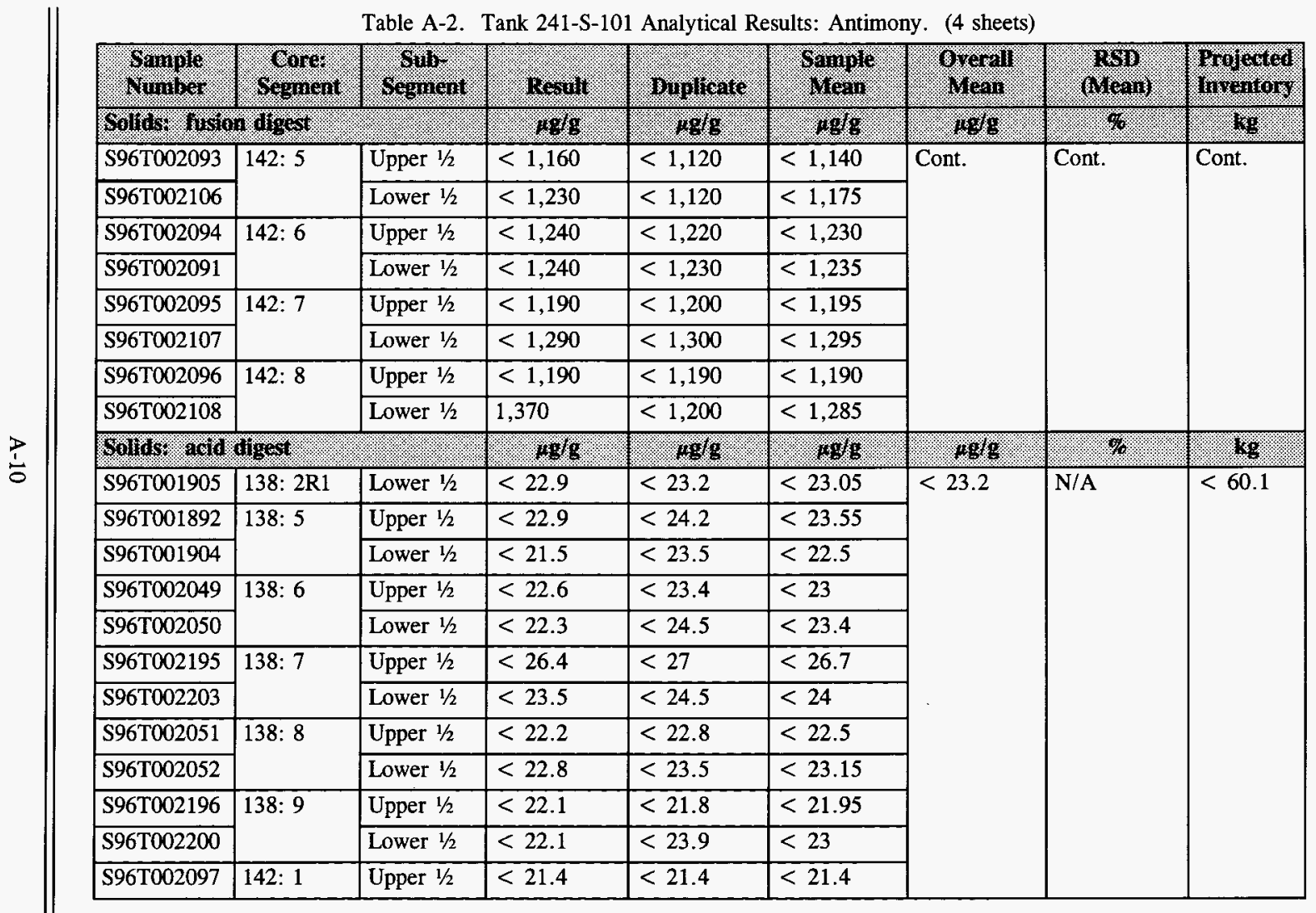


Table A-2. Tank 241-S-101 Analytical Results: Antimony. (4 sheets)

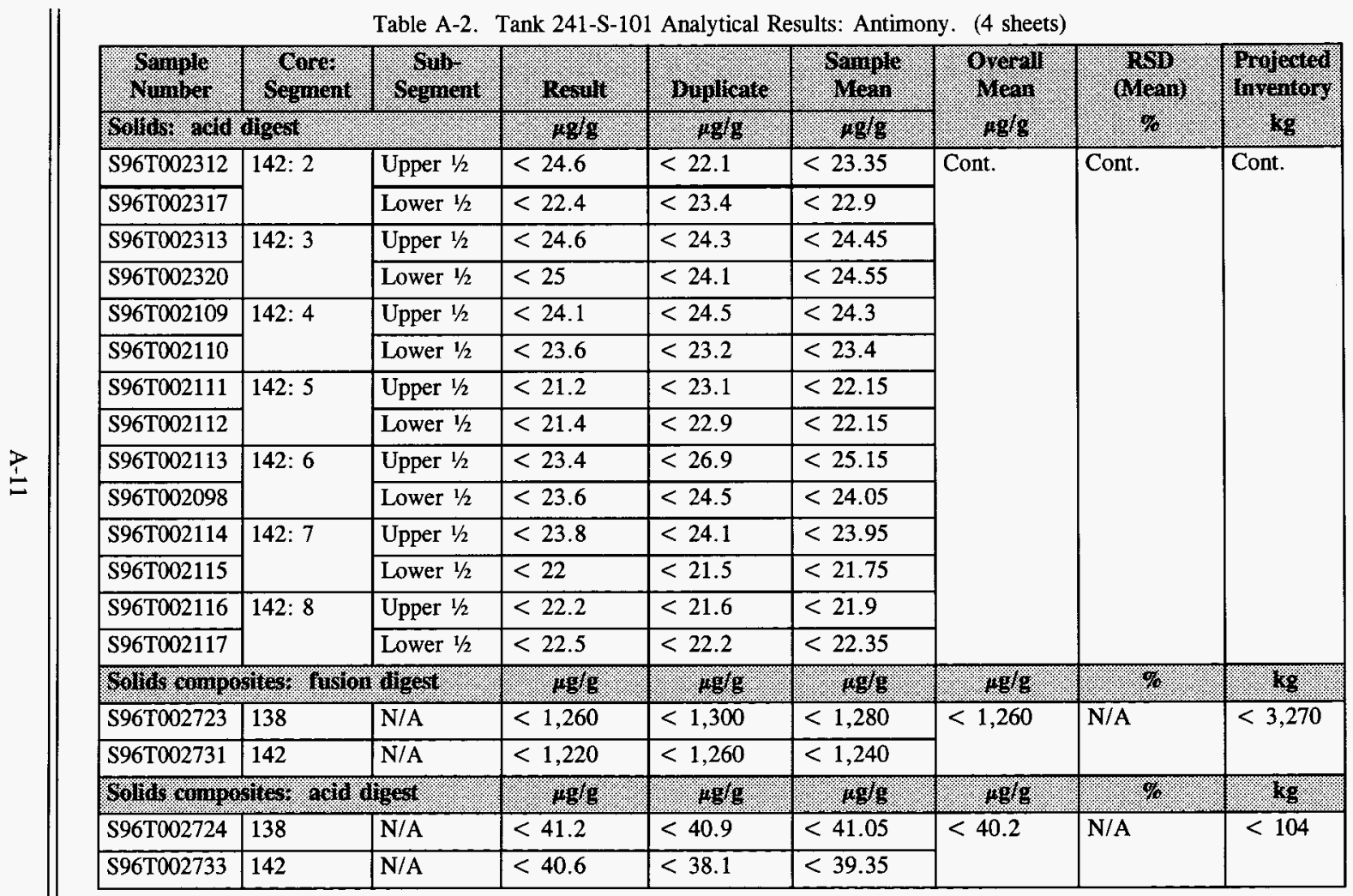




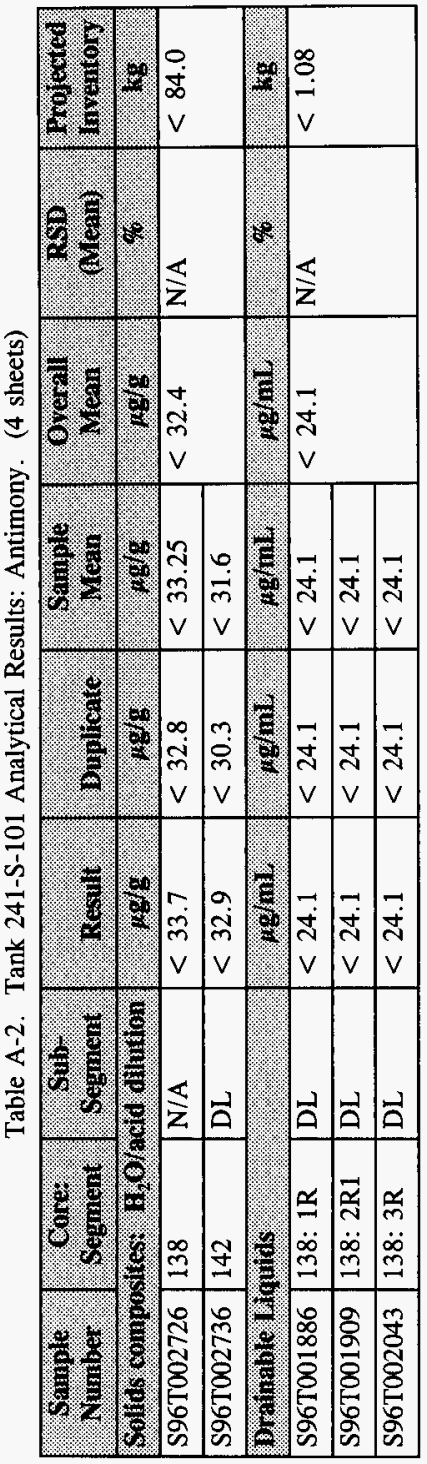




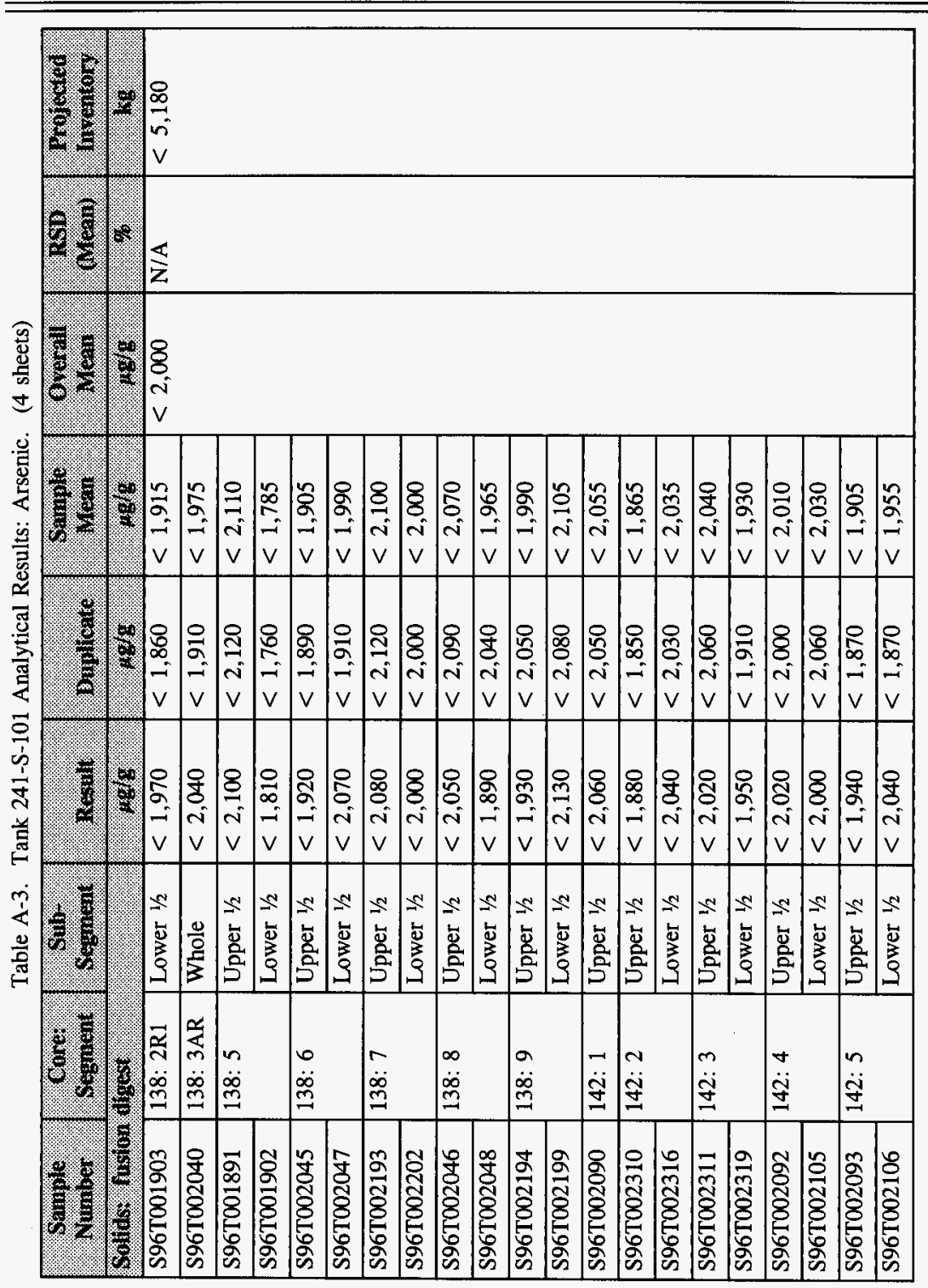


Table A-3. Tank 241-S-101 Analytical Results: Arsenic. (4 sheets)

\begin{tabular}{|c|c|c|c|c|c|c|c|c|}
\hline 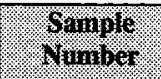 & (1) & 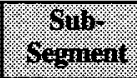 & Irsingll & Dilplate & 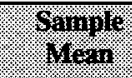 & orow & 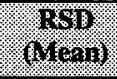 & 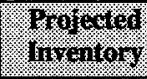 \\
\hline \multicolumn{2}{|c|}{ 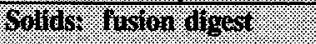 } & 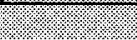 & $1.96 \mathrm{~g}$ & 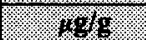 & 48 & $148 \mathrm{~g}$ & $\%$ & $.6 \mathrm{~g}$ \\
\hline S96T002094 & \multirow[t]{2}{*}{ 142: 6} & Upper $1 / 2$ & $<2,070$ & $<2,030$ & $<2,050$ & \multirow[t]{6}{*}{ Cont. } & \multirow[t]{6}{*}{ Cont. } & \multirow[t]{6}{*}{ Cont. } \\
\hline S96T002091 & & Lower $1 / 2$ & $<2,060$ & $<2,050$ & $<2,055$ & & & \\
\hline S96T002095 & \multirow[t]{2}{*}{ 142: 7} & Upper $1 / 2$ & $<1,990$ & $<2,010$ & $<2,000$ & & & \\
\hline S96T002107 & & Lower $1 / 2$ & $<2,150$ & $<2,170$ & $<2,160$ & & & \\
\hline S96T002096 & \multirow[t]{2}{*}{$142: 8$} & Upper $1 / 2$ & $<1,990$ & $<1,980$ & $<1,985$ & & & \\
\hline S96T002108 & & Lower $1 / 2$ & $<2,040$ & $<2,000$ & $<2,020$ & & & \\
\hline \multicolumn{3}{|c|}{ 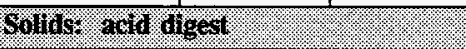 } & 198 & $18 \mathrm{~g}$ & .1818 & og 89 & $1 \%$ & 80 \\
\hline S96T001905 & 138: 2R1 & Lower $1 / 2$ & $<38.1$ & $<38.7$ & $<38.4$ & \multirow[t]{14}{*}{$<38.7$} & \multirow[t]{14}{*}{$\mathrm{N} / \mathrm{A}$} & \multirow[t]{14}{*}{$<100$} \\
\hline S96T001892 & \multirow[t]{2}{*}{$138: 5$} & Upper $1 / 2$ & $<38.2$ & $<40.3$ & $<39.25$ & & & \\
\hline S96T001904 & & Lower $1 / 2$ & $<35.8$ & $<39.2$ & $<37.5$ & & & \\
\hline S96T002049 & \multirow[t]{2}{*}{ 138: 6} & Upper $1 / 2$ & $<37.6$ & $<38.9$ & $<38.25$ & & & \\
\hline \$96T002050 & & Lower $1 / 2$ & $<37.1$ & $<40.9$ & $<39$ & & & \\
\hline S96T002195 & \multirow[t]{2}{*}{$138: 7$} & Upper $1 / 2$ & $<44$ & $<44.9$ & $<44.45$ & & & \\
\hline S96T002203 & & Lower $1 / 2$ & $<39.1$ & $<40.8$ & $<39.95$ & & & \\
\hline S96T002051 & \multirow[t]{2}{*}{ 138: 8} & Upper $1 / 2$ & $<36.9$ & $<38$ & $<37.45$ & & & \\
\hline \$96T002052 & & Lower $1 / 2$ & $<37.9$ & $<39.1$ & $<38.5$ & & & \\
\hline S96T002196 & \multirow[t]{2}{*}{ 138: 9} & Upper $1 / 2$ & $<36.9$ & $<36.4$ & $<36.65$ & & & \\
\hline S96T002200 & & Lower $1 / 2$ & $<36.8$ & $<39.8$ & $<38.3$ & & & \\
\hline S96T002097 & 142: 1 & Upper $1 / 2$ & $<35.7$ & $<35.7$ & $<35.7$ & & & \\
\hline S96T002312 & \multirow[t]{2}{*}{$142: 2$} & Upper $1 / 2$ & $<40.9$ & $<36.8$ & $<38.85$ & & & \\
\hline S96T002317 & & Lower $1 / 2$ & $<37.3$ & $<39.1$ & $<38.2$ & & & \\
\hline
\end{tabular}


WHC-SD-WM-ER-613 Rev. 0 
Table A-3. Tank 241-S-101 Analytical Results: Arsenic. (4 sheets)

\begin{tabular}{|c|c|c|c|c|c|c|c|c|}
\hline 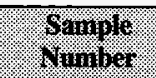 & Sogrinin & Sols & Resull & Buplatate & Sorrite & Orearl & Rean & $\begin{array}{l}\text { Projerted } \\
\text { Intrentory }\end{array}$ \\
\hline \multicolumn{3}{|c|}{ 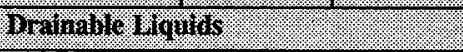 } & 68tw1 & W\%11. & ofroil. & 109411 & \% & 16 \\
\hline S96T001886 & 138: 1R & DL & $<40.1$ & $<40.1$ & $<40.1$ & \multirow[t]{3}{*}{$<40.1$} & \multirow[t]{3}{*}{ N/A } & \multirow[t]{3}{*}{$<1.80$} \\
\hline \$96T001909 & 138: 2R1 & DL & $<40.1$ & $<40.1$ & $<40.1$ & & & \\
\hline S96T002043 & 138: $3 \mathrm{R}$ & $\mathrm{DL}$ & $<40.1$ & $<40.1$ & $<40.1$ & & & \\
\hline
\end{tabular}


Table A-4. Tank 241-S-101 Analytical Results: Barium. (4 sheets)

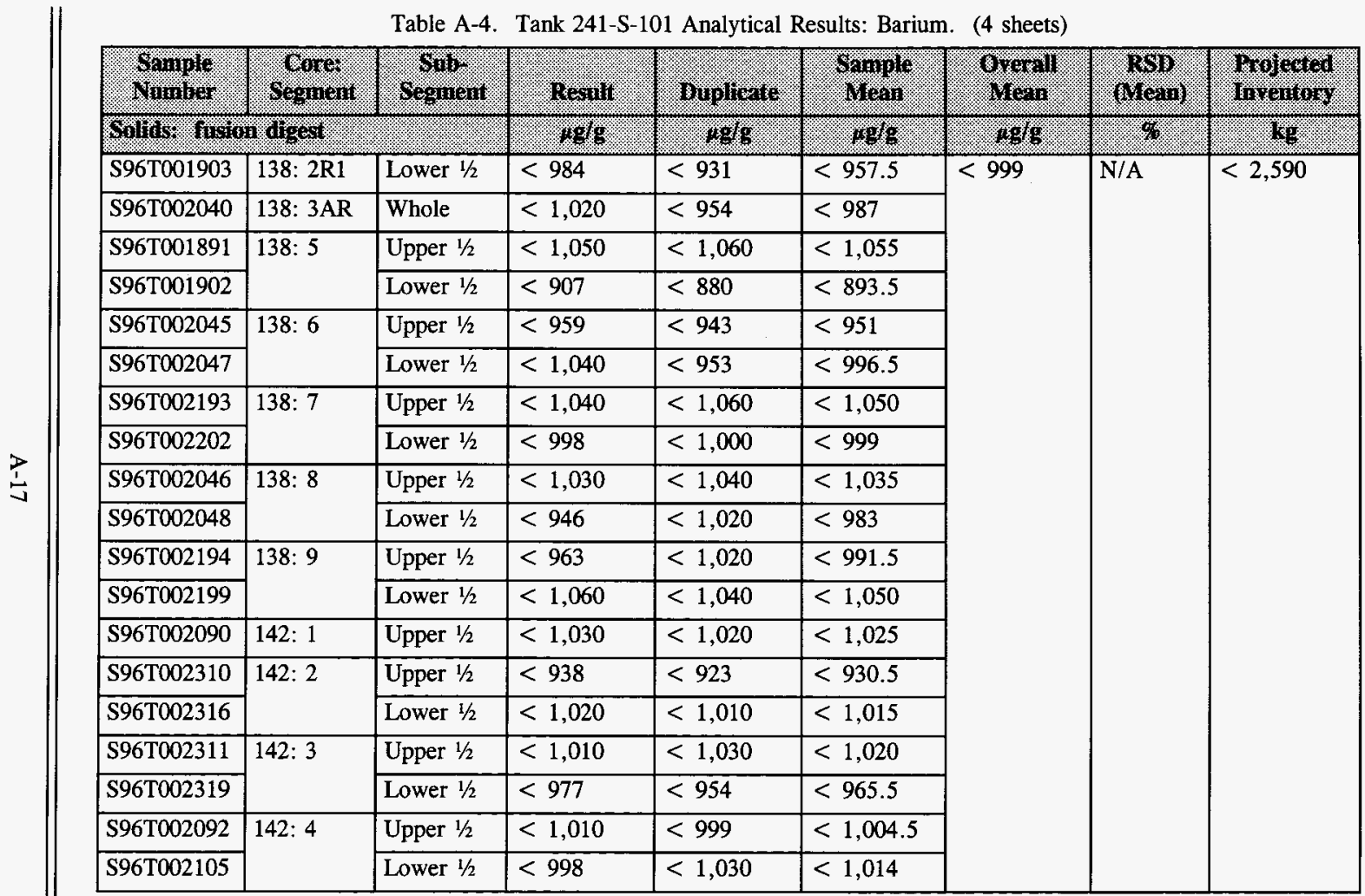




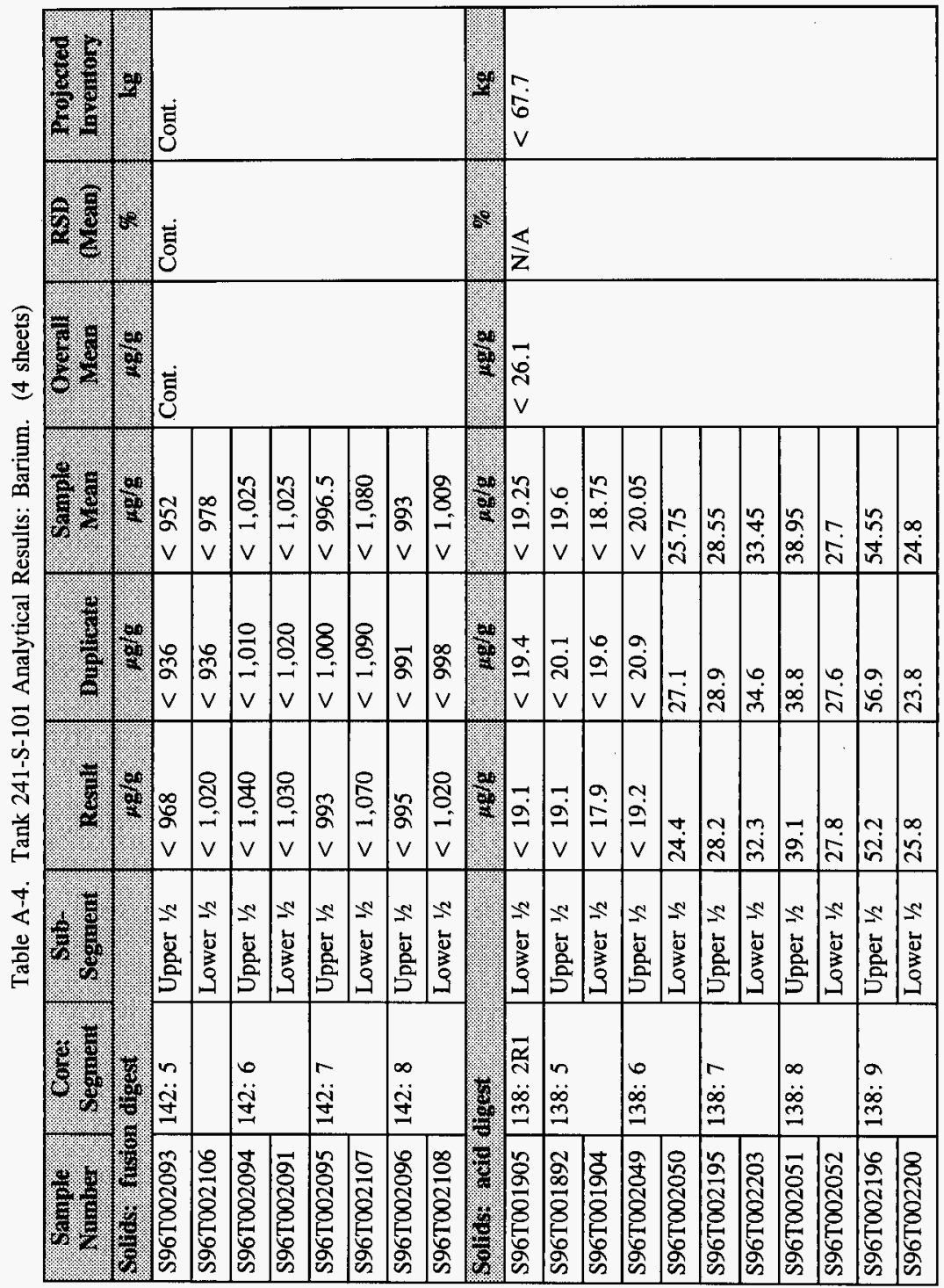


Table A-4. Tank 241-S-101 Analytical Results: Barium. (4 sheets)

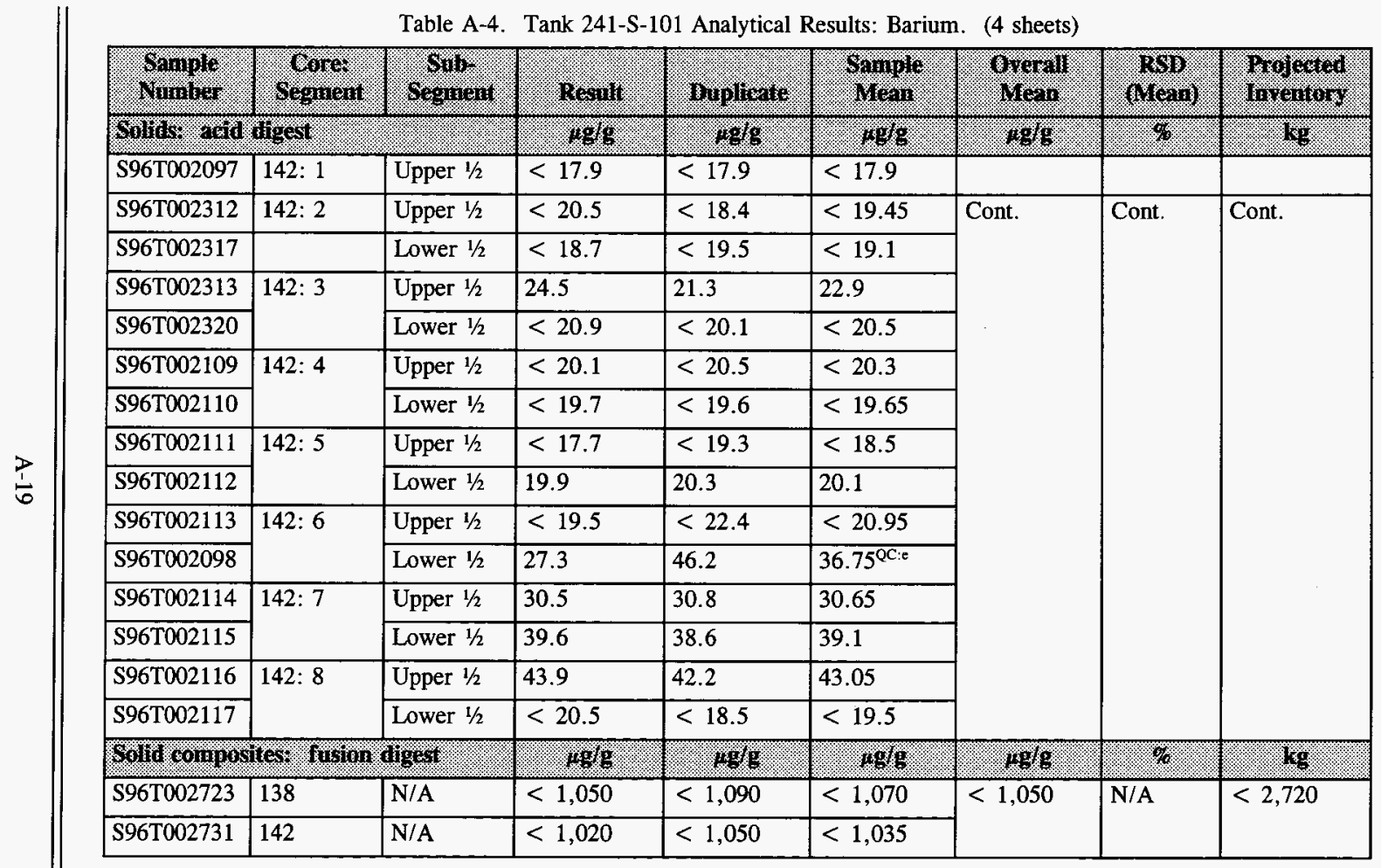


Table A-4. Tank 241-S-101 Analytical Results: Barium. (4 sheets)

\begin{tabular}{|c|c|c|c|c|c|c|c|c|}
\hline Whines & $\alpha^{2} / \cos _{110}$ & Goginerit & 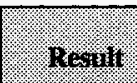 & muplucute & Woral & woral & 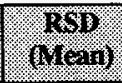 & Hownory \\
\hline \multicolumn{3}{|c|}{ Folt composiles ard Gipest } & 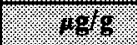 & 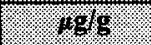 & mg & 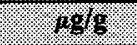 & 16 & 198 \\
\hline S96T002724 & 138 & N/A & $<34.3$ & $<34.1$ & $<34.2$ & \multirow[t]{2}{*}{$<33.5$} & \multirow[t]{2}{*}{ N/A } & \multirow[t]{2}{*}{$<86.8$} \\
\hline S96T002733 & 142 & N/A & $<33.8$ & $<31.7$ & $<32.75$ & & & \\
\hline \multicolumn{3}{|c|}{ 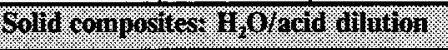 } & 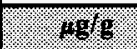 & 480 & 1998 & 196/g & (2) & 9.98 \\
\hline S96T002726 & 138 & N/A & $<28.1$ & $<27.3$ & $<27.7$ & \multirow[t]{2}{*}{$<27.0$} & \multirow[t]{2}{*}{ N/A } & \multirow[t]{2}{*}{$<70.0$} \\
\hline S96T002736 & 142 & N/A & $<27.4$ & $<25.2$ & $<26.3$ & & & \\
\hline \multicolumn{3}{|c|}{ 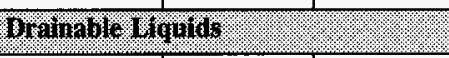 } & .89111 & 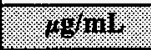 & .1921111 & $14 \mathrm{~g} / \mathrm{mi}$ & (3) & $1.16 \mathrm{~kg}$ \\
\hline S96T001886 & 138: $1 \mathrm{R}$ & DL & $<20.1$ & $<20.1$ & $<20.1$ & \multirow[t]{3}{*}{$<20.1$} & \multirow[t]{3}{*}{ N/A } & \multirow[t]{3}{*}{$<0.905$} \\
\hline \$96T001909 & 138: 2R1 & DL & $<20.1$ & $<20.1$ & $<20.1$ & & & \\
\hline S96T002043 & 138: $3 \mathrm{R}$ & $\mathrm{DL}$ & $<20.1$ & $<20.1$ & $<20.1$ & & & \\
\hline
\end{tabular}


Table A-5. Tank 241-S-101 Analytical Results: Beryllium. (4 sheets)

\begin{tabular}{|c|c|c|c|c|c|c|c|c|}
\hline Marrule & 6oprorl & ofomingl & Rerull & Buplicate & Wrish & Hoghin & 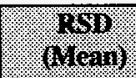 & Mrouguted \\
\hline \multicolumn{3}{|c|}{ 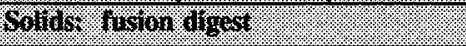 } & W/y & 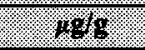 & 1.496 & (3) & 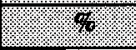 & 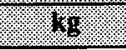 \\
\hline S96T001903 & 138: 2R1 & Lower $1 / 2$ & $<98.4$ & $<93.1$ & $<95.75$ & \multirow[t]{21}{*}{$<99.9$} & \multirow[t]{21}{*}{ N/A } & \multirow[t]{21}{*}{$<259$} \\
\hline S96T002040 & 138: $3 \mathrm{AR}$ & Whole & $<102$ & $<95.4$ & $<98.7$ & & & \\
\hline S96T001891 & \multirow[t]{2}{*}{ 138: 5} & Upper $1 / 2$ & $<105$ & $<106$ & $<105.5$ & & & \\
\hline S96T001902 & & Lower $1 / 2$ & $<90.7$ & $<88$ & $<89.35$ & & & \\
\hline \$96T002045 & \multirow[t]{2}{*}{ 138: 6} & Upper $1 / 2$ & $<95.9$ & $<94.3$ & $<95.1$ & & & \\
\hline S96T002047 & & Lower $1 / 2$ & $<104$ & $<95.3$ & $<99.65$ & & & \\
\hline S96T002193 & \multirow[t]{2}{*}{ 138: 7} & Upper $1 / 2$ & $<104$ & $<106$ & $<105$ & & & \\
\hline S96T002202 & & Lower $1 / 2$ & $<99.8$ & $<100$ & $<99.9$ & & & \\
\hline S96T002046 & \multirow[t]{2}{*}{ 138: 8} & Upper $1 / 2$ & $<103$ & $<104$ & $<103.5$ & & & \\
\hline S96T002048 & & Lower $1 / 2$ & $<94.6$ & $<102$ & $<98.3$ & & & \\
\hline S96T002194 & \multirow[t]{2}{*}{ 138: 9} & Upper $1 / 2$ & $<96.3$ & $<102$ & $<99.15$ & & & \\
\hline S96T002199 & & Lower $1 / 2$ & $<106$ & $<104$ & $<105$ & & & \\
\hline S96T002090 & 142: 1 & Upper $1 / 2$ & $<103$ & $<102$ & $<102.5$ & & & \\
\hline S96T002310 & \multirow[t]{2}{*}{$142: 2$} & Upper $1 / 2$ & $<93.8$ & $<92.3$ & $<93.05$ & & & \\
\hline S96T002316 & & Lower $1 / 2$ & $<102$ & $<101$ & $<101.5$ & & & \\
\hline \$96T002311 & \multirow[t]{2}{*}{$142: 3$} & Upper $1 / 2$ & $<101$ & $<103$ & $<102$ & & & \\
\hline S96T002319 & & Lower $1 / 2$ & $<97.7$ & $<95.4$ & $<96.55$ & & & \\
\hline S96T002092 & \multirow[t]{2}{*}{ 142: 4} & Upper $1 / 2$ & $<101$ & $<99.9$ & $<100.45$ & & & \\
\hline S96T002105 & & Lower $1 / 2$ & $<99.8$ & $<103$ & $<101.4$ & & & \\
\hline S96T002093 & \multirow[t]{2}{*}{$142: 5$} & Upper $1 / 2$ & $<96.8$ & $<93.6$ & $<95.2$ & & & \\
\hline \$96T002106 & & Lower $1 / 2$ & $<102$ & $<93.6$ & $<97.8$ & & & \\
\hline
\end{tabular}


Table A-5. Tank 241-S-101 Analytical Results: Beryllium. (4 sheets)

\begin{tabular}{|c|c|c|c|c|c|c|c|c|}
\hline Gormor & 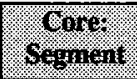 & ogingin & Iresuil & Biplicate & Waine & ofongl & 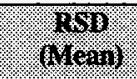 & Whatho \\
\hline \multicolumn{3}{|c|}{ 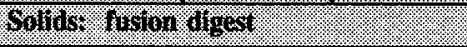 } & 148 & . & 1096 & 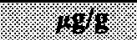 & $1 \%$ & 1.68 \\
\hline S96T002094 & \multirow[t]{2}{*}{ 142: 6} & Upper $1 / 2$ & $<104$ & $<101$ & $<102.5$ & \multirow[t]{6}{*}{ Cont. } & \multirow[t]{6}{*}{ Cont. } & \multirow[t]{6}{*}{ Cont. } \\
\hline S96T002091 & & Lower $1 / 2$ & $<103$ & $<102$ & $<102.5$ & & & \\
\hline S96T002095 & \multirow[t]{2}{*}{ 142: 7} & Upper $1 / 2$ & $<99.3$ & $<100$ & $<99.65$ & & & \\
\hline S96T002107 & & Lower $1 / 2$ & $<107$ & $<109$ & $<108$ & & & \\
\hline S96T002096 & \multirow[t]{2}{*}{ 142: 8} & Upper $1 / 2$ & $<\overline{99.5}$ & $<99.1$ & $<99.3$ & & & \\
\hline S96T002108 & & Lower $1 / 2$ & $<102$ & $<99.8$ & $<100.9$ & & & \\
\hline \multicolumn{2}{|c|}{ 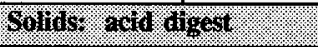 } & & 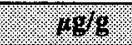 & 1.989 & .1481 & 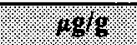 & (8) & 6y \\
\hline S96T001905 & 138: 2R1 & Lower $1 / 2$ & $<1.91$ & $<1.94$ & $<1.925$ & \multirow[t]{14}{*}{$<1.94$} & \multirow[t]{14}{*}{ N/A } & \multirow[t]{14}{*}{$<5.03$} \\
\hline S96T001892 & \multirow[t]{2}{*}{ 138: 5} & Upper $1 / 2$ & $<1.91$ & $<2.01$ & $<1.96$ & & & \\
\hline S96T001904 & & Lower $1 / 2$ & $<1.79$ & $<1.96$ & $<1.875$ & & & \\
\hline S96T002049 & \multirow[t]{2}{*}{ 138: 6} & Upper $1 / 2$ & $<1.88$ & $<1.95$ & $<1.915$ & & & \\
\hline S96T002050 & & Lower $1 / 2$ & $<1.85$ & $<2.04$ & $<1.945$ & & & \\
\hline S96T002195 & \multirow[t]{2}{*}{ 138: 7} & Upper $1 / 2$ & $<2.2$ & $<2.25$ & $<2.225$ & & & \\
\hline S96T002203 & & Lower $1 / 2$ & $<1.96$ & $<2.04$ & $<2.00$ & & & \\
\hline S96T002051 & \multirow[t]{2}{*}{$138: 8$} & Upper $1 / 2$ & $<1.85$ & $<1.9$ & $<1.875$ & & & \\
\hline S96T002052 & & Lower $1 / 2$ & $<1.9$ & $<1.96$ & $<1.93$ & & & \\
\hline S96T002196 & \multirow[t]{2}{*}{$138: 9$} & Upper $1 / 2$ & $<1.85$ & $<1.82$ & $<1.835$ & & & \\
\hline S96T002200 & & Lower $1 / 2$ & $<1.84$ & $<1.99$ & $<1.915$ & & & \\
\hline S96T002097 & 142: 1 & Upper $1 / 2$ & $<1.79$ & $<1.79$ & $<1.79$ & & & \\
\hline \$96T002312 & \multirow[t]{2}{*}{ 142: 2} & Upper $1 / 2$ & $<2.05$ & $<1.84$ & $<1.945$ & & & \\
\hline S96T002317 & & Lower $1 / 2$ & $<1.87$ & $<1.95$ & $<1.91$ & & & \\
\hline
\end{tabular}




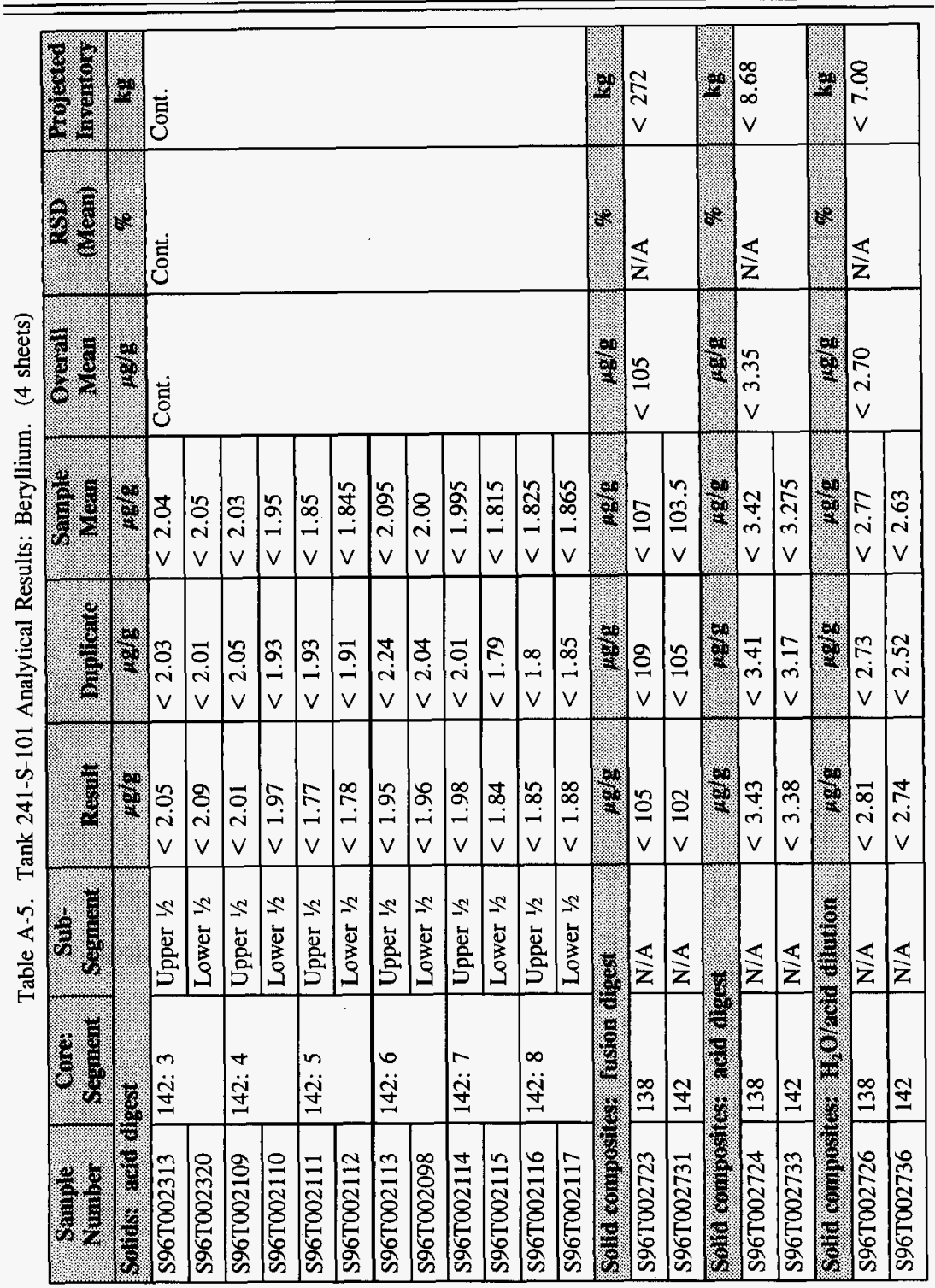


Table A-5. Tank 241-S-101 Analytical Results: Beryllium. (4 sheets)

\begin{tabular}{|c|c|c|c|c|c|c|c|c|}
\hline 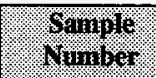 & / & ofing & nesiots & Bupleate & 94anle & 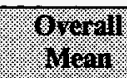 & 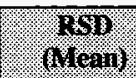 & 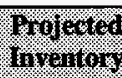 \\
\hline \multicolumn{3}{|c|}{ Mranablo hivins. } & 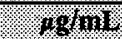 & $107 \mathrm{nI}$ & 109116 & \%\%11 & (2) & 68 \\
\hline S96T001886 & 138: 1R & DL & $<2.00$ & $<2.00$ & $<2.00$ & \multirow[t]{3}{*}{$<2.00$} & \multirow[t]{3}{*}{$\mathrm{N} / \mathrm{A}$} & \multirow[t]{3}{*}{$<0.0900$} \\
\hline S96T001909 & 138: 2R1 & $\overline{\mathrm{DL}}$ & $<2.00$ & $<2.00$ & $<2.00$ & & & \\
\hline S96T002043 & 138: 3R & DL & $<2.00$ & $<2.00$ & $<2.00$ & & & \\
\hline
\end{tabular}


Table A-6. Tank 241-S-101 Analytical Results: Bismuth. (4 sheets)

\begin{tabular}{|c|c|c|c|c|c|c|c|c|}
\hline Kaninger & 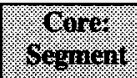 & 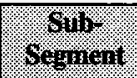 & Iresint & Biplieate & 3and & (6) & $(4 \log )$ & Droug \\
\hline \multicolumn{3}{|c|}{ 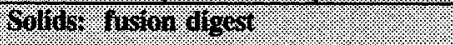 } & 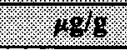 & 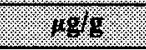 & . 198 & (1) 14 & $1 \%$ & 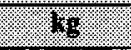 \\
\hline S96T001903 & 138: 2R1 & Lower $1 / 2$ & $<1,970$ & $<1,860$ & $<1,915$ & \multirow[t]{21}{*}{$<2,000$} & \multirow[t]{21}{*}{ N/A } & \multirow[t]{21}{*}{$<5,180$} \\
\hline S96T002040 & 138: $3 \mathrm{AR}$ & Whole & $<2,040$ & $<1,910$ & $<1,975$ & & & \\
\hline S96T001891 & \multirow[t]{2}{*}{ 138: 5} & Upper $1 / 2$ & $<2,100$ & $<2,120$ & $<2,110$ & & & \\
\hline S96T001902 & & Lower $1 / 2$ & $<1,810$ & $<1,760$ & $<1,785$ & & & \\
\hline S96T002045 & \multirow[t]{2}{*}{ 138: 6} & Upper $1 / 2$ & $<1,920$ & $<1,890$ & $<1,905$ & & & \\
\hline S96T002047 & & Lower $1 / 2$ & $<2,070$ & $<1,910$ & $<1,990$ & & & \\
\hline S96T002193 & \multirow[t]{2}{*}{ 138: 7} & Upper $1 / 2$ & $<2,080$ & $<2,120$ & $<2,100$ & & & \\
\hline S96T002202 & & Lower $1 / 2$ & $<2,000$ & $<2,000$ & $<2,000$ & & & \\
\hline S96T002046 & \multirow[t]{2}{*}{ 138: 8} & Upper $1 / 2$ & $<2,050$ & $<2,090$ & $<2,070$ & & & \\
\hline S96T002048 & & Lower $1 / 2$ & $<1,890$ & $<2,040$ & $<1,965$ & & & \\
\hline S96T002194 & \multirow[t]{2}{*}{ 138: 9} & Upper $1 / 2$ & $<1,930$ & $<2,050$ & $<1,990$ & & & \\
\hline S96T002199 & & Lower $1 / 2$ & $<2,130$ & $<2,080$ & $<2,105$ & & & \\
\hline S96T002090 & 142: 1 & Upper $1 / 2$ & $<2,060$ & $<2,050$ & $<2,055$ & & & \\
\hline S96T002310 & \multirow[t]{2}{*}{ 142: 2} & Upper $1 / 2$ & $<1,880$ & $<1,850$ & $<1,865$ & & & \\
\hline S96T002316 & & Lower $1 / 2$ & $<2,040$ & $<2,030$ & $<2,035$ & & & \\
\hline S96T002311 & \multirow[t]{2}{*}{$142: 3$} & Upper $1 / 2$ & $<2,020$ & $<2,060$ & $<2,040$ & & & \\
\hline \$96T002319 & & Lower $1 / 2$ & $<1,950$ & $<1,910$ & $<1,930$ & & & \\
\hline S96T002092 & \multirow[t]{2}{*}{$142: 4$} & Upper $1 / 2$ & $<2,020$ & $<2,000$ & $<2,010$ & & & \\
\hline S96T002105 & & Lower $1 / 2$ & $<2,000$ & $<2,060$ & $<2,030$ & & & \\
\hline S96T002093 & \multirow[t]{2}{*}{$142: 5$} & Upper $1 / 2$ & $<1,940$ & $<1,870$ & $<1,905$ & & & \\
\hline S96T002106 & & Lower $1 / 2$ & $<2,040$ & $<1,870$ & $<1,955$ & & & \\
\hline
\end{tabular}


Table A-6. Tank 241-S-101 Analytical Results: Bismuth. (4 sheets)

\begin{tabular}{|c|c|c|c|c|c|c|c|c|}
\hline Sampe & 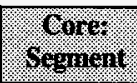 & 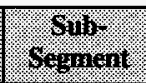 & resulf & Bullicater. & 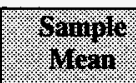 & Whatil & $(4010)$ & 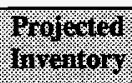 \\
\hline \multicolumn{3}{|c|}{ 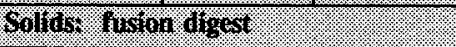 } & $196 \%$ & 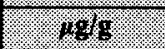 & 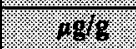 & 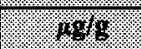 & \% & 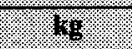 \\
\hline S96T002094 & 142: 6 & Upper $1 / 2$ & $<2,070$ & $<2,030$ & $<2,050$ & \multirow[t]{6}{*}{ Cont. } & \multirow[t]{6}{*}{ Cont. } & \multirow[t]{6}{*}{ Cont. } \\
\hline S96T002091 & & Lower $1 / 2$ & $<2,060$ & $<2,050$ & $<2,055$ & & & \\
\hline S96T002095 & \multirow[t]{2}{*}{ 142: 7} & Upper $1 / 2$ & $<1,990$ & $<2,010$ & $<2,000$ & & & \\
\hline S96T002107 & & Lower $1 / 2$ & $<2,150$ & $<2,170$ & $<2,160$ & & & \\
\hline S96T002096 & \multirow[t]{2}{*}{ 142: 8} & Upper $1 / 2$ & $<1,990$ & $<1,980$ & $<1,985$ & & & \\
\hline S96T002108 & & Lower 1/2 & $<2,040$ & $<2,000$ & $<2,020$ & & & \\
\hline \multicolumn{3}{|c|}{ 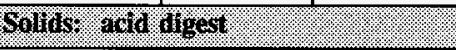 } & 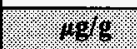 & 6.48 & $48 \%$ & 496 & \%. & \% \\
\hline S96T001905 & 138: 2R1 & Lower $1 / 2$ & 53.3 & $<38.7$ & $46^{\mathrm{QC}: \mathrm{e}}$ & \multirow{14}{*}{$<47.5$} & \multirow[t]{14}{*}{ N/A } & \multirow[t]{14}{*}{$<123$} \\
\hline S96T001892 & \multirow[t]{2}{*}{$138: 5$} & Upper $1 / 2$ & 40.1 & 44.5 & 42.3 & & & \\
\hline S96T001904 & & Lower $1 / 2$ & 51.9 & 44.3 & 48.1 & & & \\
\hline S96T002049 & \multirow[t]{2}{*}{ 138: 6} & Upper $1 / 2$ & $<37.6$ & $<38.9$ & $<38.25$ & & & \\
\hline S96T002050 & & Lower $1 / 2$ & $<37.1$ & $<40.9$ & $<39$ & & & \\
\hline S96T002195 & \multirow[t]{2}{*}{$138: 7$} & Upper $1 / 2$ & $<44$ & $<44.9$ & $<44.45$ & & & \\
\hline S96T002203 & & Lower $1 / 2$ & $<39.1$ & $<40.8$ & $<39.95$ & & & \\
\hline S96T002051 & \multirow[t]{2}{*}{ 138: 8} & Upper $1 / 2$ & $<36.9$ & $<38$ & $<37.45$ & & & \\
\hline S96T002052 & & Lower $1 / 2$ & $<37.9$ & $<39.1$ & $<38.5$ & & & \\
\hline S96T002196 & \multirow[t]{2}{*}{ 138: 9} & Upper $1 / 2$ & $<36.9$ & $<36.4$ & $<36.65$ & & & \\
\hline S96T002200 & & Lower $1 / 2$ & $<36.8$ & $<39.8$ & $<38.3$ & & & \\
\hline S96T002097 & 142: 1 & Upper $1 / 2$ & 61.6 & 73.3 & 67.45 & & & \\
\hline S96T002312 & \multirow[t]{2}{*}{ 142: 2} & Upper $1 / 2$ & 60.6 & 51.3 & 55.95 & & & \\
\hline S96T002317 & & Lower $1 / 2$ & 65 & 81.2 & $73.1^{\mathrm{QC:e}}$ & & & \\
\hline
\end{tabular}


Table A-6. Tank 241-S-101 Analytical Results: Bismuth. (4 sheets)

\begin{tabular}{|c|c|c|c|c|c|c|c|c|}
\hline Wisure & ogerment & Secoment & Iforulit & Diplicate & Gangelo & Oreoll & (Mear) & 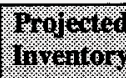 \\
\hline \multicolumn{3}{|c|}{ 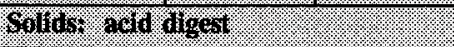 } & 1898 & $69 \%$ & Y 64 & 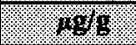 & $1 \%$ & 6 \\
\hline S96T002313 & \multirow[t]{2}{*}{$142: 3$} & Upper $1 / 2$ & $<41$ & $<40.5$ & $<40.75$ & \multirow[t]{12}{*}{ Cont. } & \multirow[t]{12}{*}{ Cont. } & \multirow[t]{12}{*}{ Cont. } \\
\hline S96T002320 & & Lower $1 / 2$ & 60.9 & 61.3 & 61.1 & & & \\
\hline S96T002109 & \multirow[t]{2}{*}{ 142: 4} & Upper $1 / 2$ & 64.6 & 78.4 & 71.5 & & & \\
\hline S96T002110 & & Lower $1 / 2$ & 75.9 & 83.2 & 79.55 & & & \\
\hline S96T002111 & \multirow[t]{2}{*}{ 142: 5} & Upper $1 / 2$ & $<35.3$ & $<38.6$ & $<36.95$ & & & \\
\hline S96T002112 & & Lower $1 / 2$ & $<35.7$ & $<38.2$ & $<36.95$ & & & \\
\hline S96T002113 & \multirow[t]{2}{*}{$142: 6$} & Upper $1 / 2$ & 71 & 71.9 & 71.45 & & & \\
\hline S96T002098 & & Lower $1 / 2$ & $<39.3$ & $<40.8$ & $<40.05$ & & & \\
\hline S96T002114 & \multirow[t]{2}{*}{ 142: 7} & Upper $1 / 2$ & $<39.6$ & $<40.2$ & $<39.9$ & & & \\
\hline S96T002115 & & Lower $1 / 2$ & $<36.7$ & $<35.8$ & $<36.25$ & & & \\
\hline S96T002116 & \multirow[t]{2}{*}{$142: 8$} & Upper $1 / 2$ & $<37.1$ & $<36$ & $<36.55$ & & & \\
\hline S96T002117 & & Lower $1 / 2$ & $<37.5$ & $<37$ & $<37.25$ & & & \\
\hline \multicolumn{3}{|c|}{ 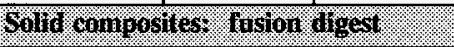 } & 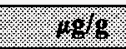 & $168 / 8$ & 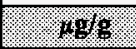 & (2. 019 & (3. & 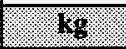 \\
\hline S96T002723 & 138 & N/A & $<2,090$ & $<2,170$ & $<2,130$ & \multirow[t]{2}{*}{$<2,100$} & \multirow[t]{2}{*}{ N/A } & \multirow[t]{2}{*}{$<5,440$} \\
\hline S96T002731 & 142 & N/A & $<2,040$ & $<2,100$ & $<2,070$ & & & \\
\hline \multicolumn{3}{|c|}{ 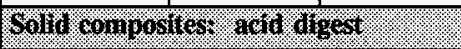 } & 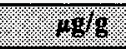 & .698 & $6.68 \mathrm{~s}$ & 49 & . & 18 \\
\hline S96T002724 & 138 & N/A & $<68.6$ & $<68.2$ & $<68.4$ & \multirow[t]{2}{*}{$<67.0$} & \multirow[t]{2}{*}{ N/A } & \multirow[t]{2}{*}{$<174$} \\
\hline S96T002733 & 142 & N/A & $<67.7$ & $<63.5$ & $<65.6$ & & & \\
\hline \multicolumn{3}{|c|}{ 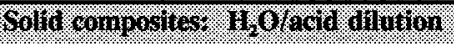 } & 1086 & .1898 & $.104 \mathrm{~g}$ & 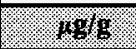 & \% & . \\
\hline S96T002726 & 138 & N/A & $<56.2$ & $<54.6$ & $<55.4$ & \multirow[t]{2}{*}{$<54.0$} & \multirow[t]{2}{*}{ N/A } & \multirow[t]{2}{*}{$<140$} \\
\hline S96T002736 & 142 & N/A & $<54.8$ & $<50.4$ & $<52.6$ & & & \\
\hline
\end{tabular}


Table A-6. Tank 241-S-101 Analytical Results: Bismuth. (4 sheets)

\begin{tabular}{|c|c|c|c|c|c|c|c|c|}
\hline Moninus & of & \%olment & Merall & Buylueate & $y_{100}$ & Whar & 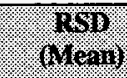 & Wrowered \\
\hline \multicolumn{3}{|c|}{ 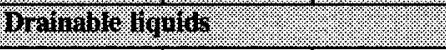 } & Hotin & HIM\% & \% & Hory & 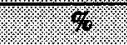 & 19. \\
\hline S96T001886 & 138: 1R & DL & $<40.1$ & $<40.1$ & $<40.1$ & \multirow[t]{3}{*}{$<40.1$} & \multirow[t]{3}{*}{ N/A } & \multirow[t]{3}{*}{$<1.80$} \\
\hline S96T001909 & 138: 2R1 & DL & $<40.1$ & $<40.1$ & $<40.1$ & & & \\
\hline S96T002043 & 138: 3R & DL & $<40.1$ & $<40.1$ & $<40.1$ & & & \\
\hline
\end{tabular}




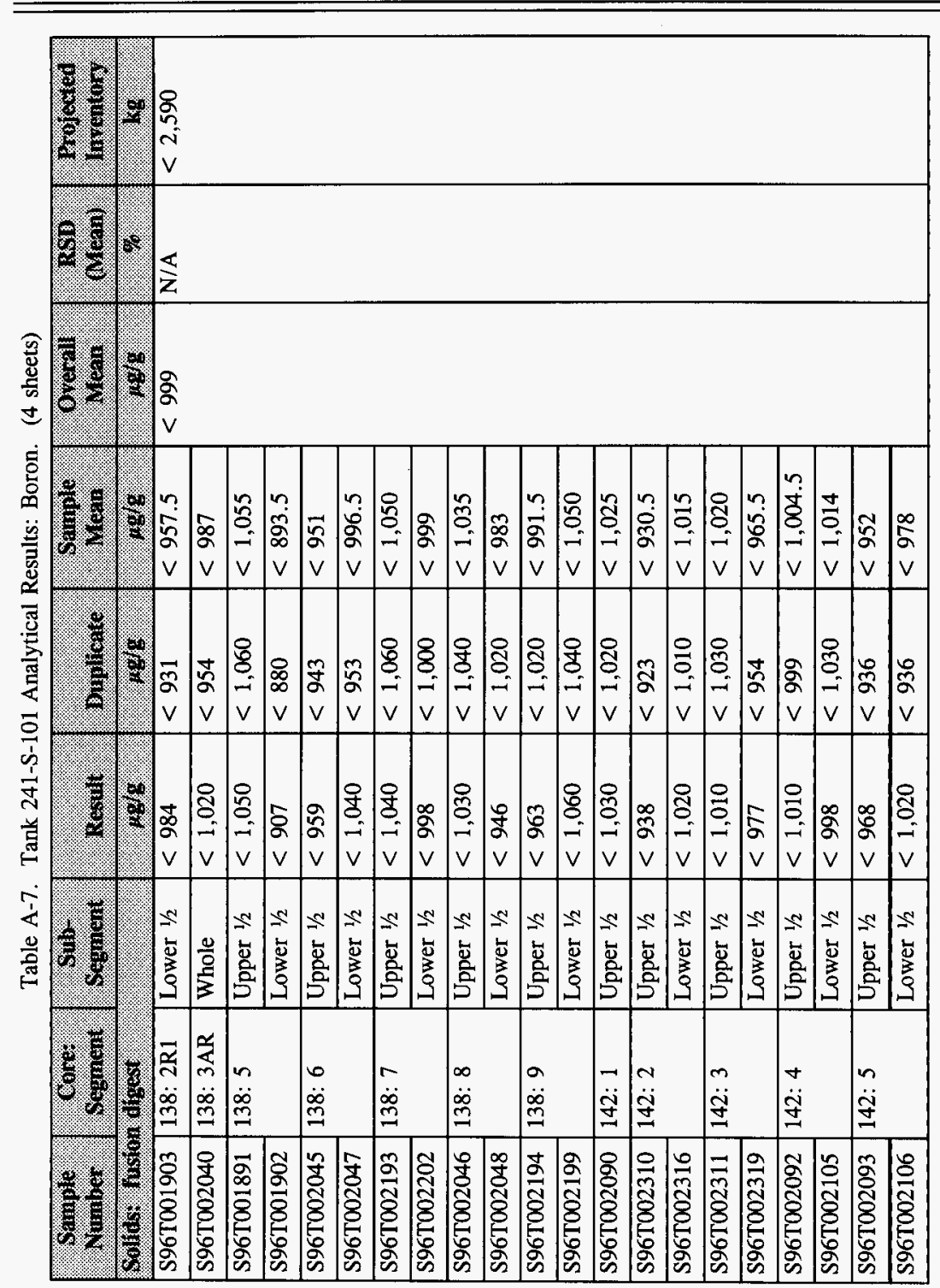


Table A-7. Tank 241-S-101 Analytical Results: Boron. (4 sheets)

\begin{tabular}{|c|c|c|c|c|c|c|c|c|}
\hline Samilo & $40817 \%$ & \%ormint & Resuil & Oujilgute & Wariog & 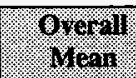 & 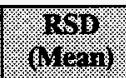 & 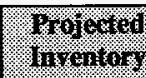 \\
\hline \multicolumn{3}{|c|}{ 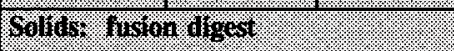 } & 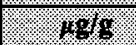 & .9618. & 4040 & 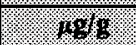 & $\%$ & k. \\
\hline S96T002094 & $142: 6$ & Upper $1 / 2$ & $<1,040$ & $<1,010$ & $<1,025$ & \multirow[t]{6}{*}{ Cont. } & \multirow[t]{6}{*}{ Cont. } & \multirow[t]{6}{*}{ Cont. } \\
\hline S96T002091 & & Lower $1 / 2$ & $<1,030$ & $<1,020$ & $<1, \overline{025}$ & & & \\
\hline S96T002095 & \multirow[t]{2}{*}{ 142: 7} & Upper $1 / 2$ & $<993$ & $<1,000$ & $<996.5$ & & & \\
\hline S96T002107 & & Lower $1 / 2$ & $<1,070$ & $<1,090$ & $<1,080$ & & & \\
\hline S96T002096 & \multirow[t]{2}{*}{ 142: 8} & Upper $1 / 2$ & $<995$ & $<991$ & $<993$ & & & \\
\hline S96T002108 & & Lower $1 / 2$ & $<1,020$ & $<998$ & $<1,009$ & & & \\
\hline \multicolumn{3}{|c|}{ 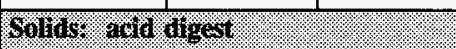 } & 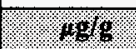 & 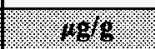 & 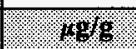 & $10 \%$ & $\sqrt{1.80}$ & 189 \\
\hline S96T001905 & 138: 2R1 & Lower $1 / 2$ & 77.3 & 78.9 & 78.1 & \multirow[t]{14}{*}{86.6} & \multirow[t]{14}{*}{24.1} & \multirow[t]{14}{*}{224} \\
\hline \$96T001892 & \multirow[t]{2}{*}{$138: 5$} & Upper $1 / 2$ & 77.1 & 83 & 80.05 & & & \\
\hline S96T001904 & & Lower $1 / 2$ & 65 & 70.6 & 67.8 & & & \\
\hline S96T002049 & \multirow[t]{2}{*}{ 138: 6} & Upper $1 / 2$ & 62.6 & 59.4 & 61.0 & & & \\
\hline S96T002050 & & Lower $1 / 2$ & 52.8 & 102 & $77.4^{\mathrm{QC}: \mathrm{e}}$ & & & \\
\hline \$96T002195 & \multirow[t]{2}{*}{ 138: 7} & Upper $1 / 2$ & 64.5 & 90.9 & $77.7^{\mathrm{QC}: \mathrm{e}}$ & & & \\
\hline S96T002203 & & Lower $1 / 2$ & 37 & 42.7 & 39.85 & & & \\
\hline S96T002051 & \multirow[t]{2}{*}{ 138: 8} & Upper $1 / 2$ & 51.6 & 80.4 & $66.0^{\mathrm{QC}: \mathrm{e}}$ & & & \\
\hline S96T002052 & & Lower $1 / 2$ & 71.2 & 20.8 & $46.0^{\mathrm{QC}: \mathrm{e}}$ & & & \\
\hline S96T002196 & \multirow[t]{2}{*}{ 138: 9} & Upper $1 / 2$ & 69.2 & 57.3 & 63.25 & & & \\
\hline S96T002200 & & Lower $1 / 2$ & 55.3 & 51.2 & 53.25 & & & \\
\hline S96T002097 & $\overline{142: 1}$ & Upper $1 / 2$ & 136 & 152 & 144 & & & \\
\hline S96T002312 & \multirow[t]{2}{*}{$142: 2$} & Upper $1 / 2$ & 163 & 123 & $143^{\mathrm{QC}: e}$ & & & \\
\hline S96T002317 & & Lower $1 / 2$ & 132 & 157 & 144.5 & & & \\
\hline
\end{tabular}


Table A-7. Tank 241-S-101 Analytical Results: Boron. (4 sheets)

\begin{tabular}{|c|c|c|c|c|c|c|c|c|}
\hline ganulo & 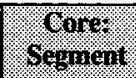 & (6) & $\sin 6 \sin$ & Bubleate & Wolape & oreril & 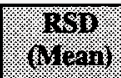 & 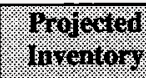 \\
\hline \multicolumn{2}{|c|}{ 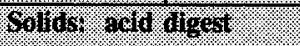 } & \% & $\% 010$ & $168 \%$ & 1019 & 1018 & 18 & kg. \\
\hline S96T002313 & \multirow[t]{2}{*}{ 142: 3} & Upper $1 / 2$ & 75.8 & 88.9 & 82.35 & \multirow[t]{12}{*}{ Cont. } & \multirow[t]{12}{*}{ Cont. } & \multirow[t]{12}{*}{ Cont. } \\
\hline S96T002320 & & Lower $1 / 2$ & 137 & 86.1 & $111.55^{\mathrm{QC}: \mathrm{e}}$ & & & \\
\hline S96T002109 & \multirow[t]{2}{*}{$142: 4$} & Upper $1 / 2$ & 132 & 144 & 138 & & & \\
\hline \$96T002110 & & Lower $1 / 2$ & 70.1 & 58.1 & 64.1 & & & \\
\hline S96T002111 & \multirow[t]{2}{*}{$142: 5$} & Upper $1 / 2$ & 64.2 & 110 & $87.1^{\mathrm{QC}: \mathrm{e}}$ & & & \\
\hline S96T002112 & & Lower $1 / 2$ & 88 & 63.5 & $75.75^{\text {QC:e }}$ & & & \\
\hline S96T002113 & \multirow[t]{2}{*}{$142: 6$} & Upper $1 / 2$ & 157 & 133 & 145 & & & \\
\hline S96T002098 & & Lower $1 / 2$ & 114 & 229 & $171.5^{\mathrm{QC}: \mathrm{c}}$ & & & \\
\hline S96T002114 & \multirow[t]{2}{*}{ 142: 7} & Upper $1 / 2$ & 57.8 & 43.8 & $50.8^{\mathrm{QC}: \mathrm{e}}$ & & & \\
\hline S96T002115 & & Lower $1 / 2$ & 51.9 & 49.2 & 50.55 & & & \\
\hline S96T002116 & \multirow[t]{2}{*}{ 142: 8} & Upper $1 / 2$ & 77.9 & 77.7 & 77.8 & & & \\
\hline S96T002117 & & Lower $1 / 2$ & 99.1 & 95.3 & 97.2 & & & \\
\hline \multicolumn{3}{|c|}{ 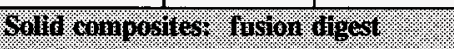 } & $18 \% 8$ & $48+6$ & $.6 \% \mathrm{~g}$ & 4.96 & 80 & 68 \\
\hline S96T002723 & 138 & N/A & $<1,050$ & $<1,090$ & $<1,070$ & \multirow[t]{2}{*}{$<1,050$} & \multirow[t]{2}{*}{ N/A } & \multirow[t]{2}{*}{$<2,720$} \\
\hline \$96T002731 & 142 & $\mathrm{~N} / \mathrm{A}$ & $<1,020$ & $<1,050$ & $<1,035$ & & & \\
\hline \multicolumn{3}{|c|}{ 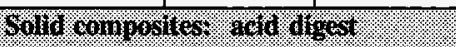 } & $.4 \% \mathrm{~g}$ & 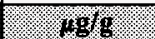 & igy & 10818 & $\%$ & 48 \\
\hline S96T002724 & 138 & N/A & $<34.3$ & 64.6 & $49.45^{\mathrm{QC}: \mathrm{e}}$ & \multirow[t]{2}{*}{54.0} & \multirow[t]{2}{*}{15.8} & \multirow[t]{2}{*}{140} \\
\hline S96T002733 & 142 & N/A & 71.3 & 45.7 & $58.5^{\mathrm{QC}: \mathrm{e}}$ & & & \\
\hline \multicolumn{3}{|c|}{ 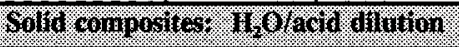 } & 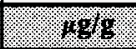 & $1 \%$ & 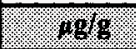 & . & 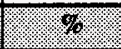 & . \\
\hline S96T002726 & 138 & N/A & 486 & 563 & 524.5 & \multirow[t]{2}{*}{446} & \multirow[t]{2}{*}{17.7} & \multirow[t]{2}{*}{1,160} \\
\hline S96T002736 & 142 & N/A & 377 & 356 & 366.5 & & & \\
\hline
\end{tabular}


Table A-7. Tank 241-S-101 Analytical Results: Boron. (4 sheets)

\begin{tabular}{|c|c|c|c|c|c|c|c|c|}
\hline Wominglo & 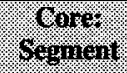 & Hasmol & Iresult & Buplaces & 89114 & Mond & 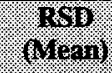 & Holesed \\
\hline \multicolumn{3}{|c|}{ 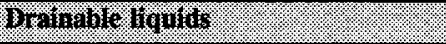 } & 181mi & Hodin & (18) & $1 \%, 111$ & 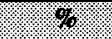 & 18. \\
\hline S96T001886 & 138: 1R & DL & 68.3 & 69 & 68.65 & \multirow[t]{3}{*}{70.1} & \multirow[t]{3}{*}{1.5} & \multirow[t]{3}{*}{3.17} \\
\hline S96T001909 & 138: $2 \mathrm{R} 1$ & DL & 69.7 & 70.7 & 70.2 & & & \\
\hline S96T002043 & 138: $3 \mathrm{R}$ & DL & 71.7 & 72.9 & 72.3 & & & \\
\hline
\end{tabular}


Table A-8. Tank 241-S-101 Analytical Results: Cadmium. (4 sheets)

\begin{tabular}{|c|c|c|c|c|c|c|c|c|}
\hline Gamplo & 6ogmol & o.grinent & $\operatorname{lig}+11$ : & bulitiale & Woling & Worilu & orith & 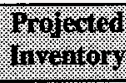 \\
\hline \multicolumn{3}{|c|}{ 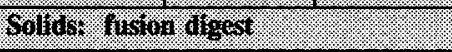 } & 1918 & 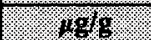 & 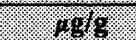 & 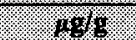 & 1. & 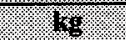 \\
\hline S96T001903 & 138: 2R1 & Lower $1 / 2$ & $<98.4$ & $<93.1$ & $<95.75$ & \multirow[t]{21}{*}{$<99.9$} & \multirow[t]{21}{*}{ N/A } & \multirow[t]{21}{*}{$<259$} \\
\hline S96T002040 & 138: $3 \mathrm{AR}$ & Whole & $<102$ & $<95.4$ & $<98.7$ & & & \\
\hline S96T001891 & \multirow[t]{2}{*}{$138: 5$} & Upper $1 / 2$ & $<105$ & $<106$ & $<105.5$ & & & \\
\hline S96T001902 & & Lower $1 / 2$ & $<90.7$ & $<88$ & $<89.35$ & & & \\
\hline S96T002045 & \multirow[t]{2}{*}{ 138: 6} & Upper $1 / 2$ & $<95.9$ & $<94.3$ & $<95.1$ & & & \\
\hline S96T002047 & & Lower $1 / 2$ & $<104$ & $<95.3$ & $<99.65$ & & & \\
\hline S96T002193 & \multirow[t]{2}{*}{ 138: 7} & Upper $1 / 2$ & $<104$ & $<106$ & $<105$ & & & \\
\hline S96T002202 & & Lower $1 / 2$ & $<99.8$ & $<100$ & $<99.9$ & & & \\
\hline S96T002046 & \multirow[t]{2}{*}{ 138: 8} & Upper $1 / 2$ & $<103$ & $<104$ & $<103.5$ & & & \\
\hline S96T002048 & & Lower $1 / 2$ & $<94.6$ & $<102$ & $<98.3$ & & & \\
\hline S96T002194 & \multirow[t]{2}{*}{ 138: 9} & Upper $1 / 2$ & $<96.3$ & $<102$ & $<99.15$ & & & \\
\hline S96T002199 & & Lower $1 / 2$ & $<106$ & $<104$ & $<105$ & & & \\
\hline \$96T002090 & 142: 1 & Upper $1 / 2$ & $<103$ & $<102$ & $<102.5$ & & & \\
\hline S96T002310 & \multirow[t]{2}{*}{ 142: 2} & Upper $1 / 2$ & $<93.8$ & $<92.3$ & $<93.05$ & & & \\
\hline S96T002316 & & Lower $1 / 2$ & $<102$ & $<101$ & $<101.5$ & & & \\
\hline S96T002311 & \multirow[t]{2}{*}{ 142: 3} & Upper $1 / 2$ & $<101$ & $<103$ & $<102$ & & & \\
\hline \$96T002319 & & Lower $1 / 2$ & $<97.7$ & $<95.4$ & $<96.55$ & & & \\
\hline S96T002092 & \multirow[t]{2}{*}{ 142: 4} & Upper $1 / 2$ & $<101$ & $<99.9$ & $<100.45$ & & & \\
\hline S96T002105 & & Lower $1 / 2$ & $<99.8$ & $<103$ & $<101.4$ & & & \\
\hline S96T002093 & \multirow[t]{2}{*}{$142: 5$} & Upper $1 / 2$ & $<96.8$ & $<93.6$ & $<95.2$ & & & \\
\hline S96T002106 & & Lower $1 / 2$ & $<102$ & $<93.6$ & $<97.8$ & & & \\
\hline
\end{tabular}


Table A-8. Tank 241-S-101 Analytical Results: Cadmium. (4 sheets)

\begin{tabular}{|c|c|c|c|c|c|c|c|c|}
\hline Mamio & . Wormer. & 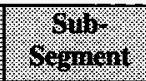 & Isoull & Bupleate & Gamaro & 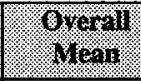 & $(1610$ & $\begin{array}{l}\text { Projpoled } \\
\text { myrotorg }\end{array}$ \\
\hline \multicolumn{3}{|c|}{ 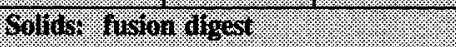 } & $.18 \%$ & 1.648 & . & $18 \% 18$ & ( & 1.48. \\
\hline S96T002094 & 142: 6 & Upper $1 / 2$ & $<104$ & $<101$ & $<102.5$ & \multirow[t]{6}{*}{ Cont. } & \multirow[t]{6}{*}{ Cont. } & \multirow[t]{6}{*}{ Cont. } \\
\hline S96T002091 & & Lower $1 / 2$ & $<103$ & $<102$ & $<102.5$ & & & \\
\hline S96T002095 & \multirow[t]{2}{*}{ 142: 7} & Upper $1 / 2$ & $<99.3$ & $<100$ & $<99.65$ & & & \\
\hline S96T002107 & & Lower $1 / 2$ & $<107$ & $<109$ & $<108$ & & & \\
\hline S96T002096 & \multirow[t]{2}{*}{ 142: 8} & Upper $1 / 2$ & $<99.5$ & $<99.1$ & $<99.3$ & & & \\
\hline S96T002108 & & Lower $1 / 2$ & $<102$ & $<99.8$ & $<100.9$ & & & \\
\hline \multicolumn{3}{|c|}{ 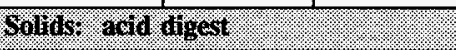 } & 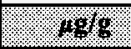 & $1.6 \%$ & $1.14 \%$ & (1. $/ g_{0}$ & $1.1 \%$ & 1.98 \\
\hline S96T001905 & 138: $2 \mathrm{R} 1$ & Lower $1 / 2$ & 6.78 & 7.03 & 6.905 & \multirow[t]{14}{*}{4.46} & \multirow[t]{14}{*}{31.4} & \multirow[t]{14}{*}{11.6} \\
\hline S96T001892 & \multirow[t]{2}{*}{$138: 5$} & Upper $1 / 2$ & 2.37 & 2.98 & $2.675^{\mathrm{QC}: \mathrm{e}}$ & & & \\
\hline S96T001904 & & Lower $1 / 2$ & 5.45 & 6.44 & 5.945 & & & \\
\hline S96T002049 & \multirow[t]{2}{*}{ 138: 6} & Upper $1 / 2$ & 2.05 & 2.32 & 2.185 & & & \\
\hline S96T002050 & & Lower $1 / 2$ & $<1.85$ & $<2.04$ & $<1.945$ & & & \\
\hline S96T002195 & \multirow[t]{2}{*}{$138: 7$} & Upper $1 / 2$ & $<2.2$ & $<2.25$ & $<2.225$ & & & \\
\hline \$96T002203 & & Lower $1 / 2$ & $<1.96$ & $<2.04$ & $<2.00$ & & & \\
\hline S96T002051 & \multirow[t]{2}{*}{$138: 8$} & Upper $1 / 2$ & $<1.85$ & $<1.9$ & $<1.875$ & & & \\
\hline S96T002052 & & Lower $1 / 2$ & $<1.9$ & $<1.96$ & $<1.93$ & & & \\
\hline S96T002196 & \multirow[t]{2}{*}{ 138: 9} & Upper $1 / 2$ & $<1.85$ & $<1.82$ & $<1.835$ & & & \\
\hline S96T002200 & & Lower $1 / 2$ & $<1.84$ & $<1.99$ & $<1.915$ & & & \\
\hline S96T002097 & 142: 1 & Upper $1 / 2$ & 9.56 & 10.1 & 9.83 & & & \\
\hline$\$ 96 \mathrm{~T} 002312$ & \multirow[t]{2}{*}{$142: 2$} & Upper $1 / 2$ & 10.2 & 9.2 & 9.7 & & & \\
\hline S96T002317 & & Lower $1 / 2$ & 10.1 & 10.5 & 10.3 & & & \\
\hline
\end{tabular}


Table A-8. Tank 241-S-101 Analytical Results: Cadmium. (4 sheets)

\begin{tabular}{|c|c|c|c|c|c|c|c|c|}
\hline Wainer & owaririt & 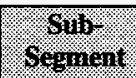 & Result & Buplagite & Whas & Wholl & $\begin{array}{l}\text { mon } \\
6 \% \text { on }\end{array}$ & Wrolestor \\
\hline \multicolumn{3}{|c|}{ 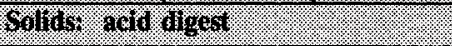 } & 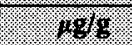 & 1918 & 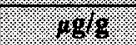 & 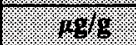 & \% & $\sqrt{68}$ \\
\hline S96T002313 & \multirow[t]{2}{*}{$142: 3$} & Upper $1 / 2$ & $<2.05$ & $<2.03$ & $<2.04$ & \multirow[t]{12}{*}{ Cont. } & \multirow[t]{12}{*}{ Cont. } & \multirow[t]{12}{*}{ Cont. } \\
\hline S96T002320 & & Lower $1 / 2$ & 10.1 & 9.98 & 10.04 & & & \\
\hline S96T002109 & \multirow[t]{2}{*}{$142: 4$} & Upper $1 / 2$ & 11.3 & 11.6 & 11.45 & & & \\
\hline S96T002110 & & Lower $1 / 2$ & 7.12 & 6.54 & 6.83 & & & \\
\hline S96T002111 & \multirow[t]{2}{*}{$142: 5$} & Upper $1 / 2$ & 1.78 & 2.32 & $2.05^{\mathrm{QC}: c}$ & & & \\
\hline S96T002112 & & Lower $1 / 2$ & 3.37 & 3.49 & 3.43 & & & \\
\hline S96T002113 & \multirow[t]{2}{*}{$142: 6$} & Upper $1 / 2$ & 9.67 & 10.9 & 10.285 & & & \\
\hline S96T002098 & & Lower $1 / 2$ & $<1.96$ & $<2.04$ & $<2$ & & & \\
\hline S96T002114 & \multirow[t]{2}{*}{$142: 7$} & Upper $1 / 2$ & $<1.98$ & $<2.01$ & $<1.995$ & & & \\
\hline S96T002115 & & Lower $1 / 2$ & $<1.84$ & $<1.79$ & $<1.815$ & & & \\
\hline S96T002116 & \multirow[t]{2}{*}{$142: 8$} & Upper $1 / 2$ & $<1.85$ & $<1.8$ & $<1.825$ & & & \\
\hline S96T002117 & & Lower $1 / 2$ & $<1.88$ & $<1.85$ & $<1.865$ & & & \\
\hline \multicolumn{3}{|c|}{ 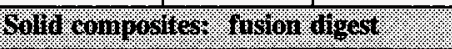 } & 1.018 & $18 / 9$ & 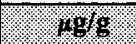 & 1.96 & \% & 188 \\
\hline S96T002723 & 138 & N/A & $<105$ & $<109$ & $<107$ & \multirow[t]{2}{*}{$<105$} & \multirow[t]{2}{*}{ N/A } & \multirow[t]{2}{*}{$<272$} \\
\hline S96T002731 & 142 & N/A & $<102$ & $<105$ & $<103.5$ & & & \\
\hline \multicolumn{3}{|c|}{ 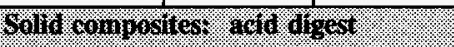 } & Ho & 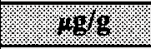 & 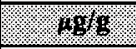 & 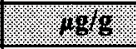 & 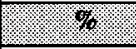 & 16 \\
\hline S96T002724 & 138 & N/A & $<3.43$ & $<3.41$ & $<3.42$ & \multirow[t]{2}{*}{3.93} & \multirow[t]{2}{*}{12.9} & \multirow[t]{2}{*}{10.2} \\
\hline S96T002733 & 142 & $\mathrm{~N} / \mathrm{A}$ & 4.86 & 4.01 & 4.435 & & & \\
\hline \multicolumn{3}{|c|}{ 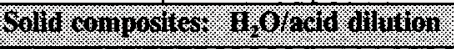 } & 4019 & 496 & 1898 & 498 & $9 \%$ & 89 \\
\hline S96T002726 & 138 & N/A & $<2.81$ & $<2.73$ & $<2.77$ & \multirow[t]{2}{*}{$<2.70$} & \multirow[t]{2}{*}{$\mathrm{N} / \mathrm{A}$} & \multirow[t]{2}{*}{$<7.00$} \\
\hline S96T002736 & 142 & N/A & $<2.74$ & $<2.52$ & $<2.63$ & & & \\
\hline
\end{tabular}


Table A-8. Tank 241-S-101 Analytical Results: Cadmium. (4 sheets)

\begin{tabular}{|c|c|c|c|c|c|c|c|c|}
\hline $\begin{array}{l}\text { Sample } \\
\text { Yrminer }\end{array}$ & Sorner & Sulb & Iresill & Bistilionte & Mamie & Orerol & MHI & $\begin{array}{l}\text { Trujectiod } \\
\text { inveriton }\end{array}$ \\
\hline \multicolumn{3}{|c|}{ Broliable hould: } & 48691 & 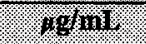 & Hovi. & 19101 & 16 & so \\
\hline S96T001886 & 138: 1R & $\mathrm{DL}$ & $<2.00$ & $<2.00$ & $<2.00$ & \multirow[t]{3}{*}{$<2.00$} & \multirow[t]{3}{*}{ N/A } & \multirow[t]{3}{*}{$<0.0900$} \\
\hline S96T001909 & 138: 2R1 & $\mathrm{DL}$ & $<2.00$ & $<2.00$ & $<2.00$ & & & \\
\hline S96T002043 & 138: $3 \mathrm{R}$ & $\overline{\mathrm{DL}}$ & $<2.00$ & $<2.00$ & $<2.00$ & & & \\
\hline
\end{tabular}


Table A-9. Tank 241-S-101 Analytical Results: Calcium. (4 sheets)

\begin{tabular}{|c|c|c|c|c|c|c|c|c|}
\hline 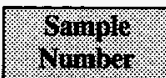 & 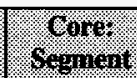 & ocoment & $18+5111$ & Dupluate & Golur & Moral & $\begin{array}{l}1613 \\
640113\end{array}$ & Wrojqutor \\
\hline \multicolumn{3}{|c|}{ 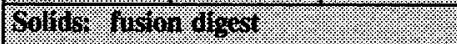 } & /. & 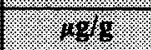 & 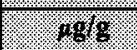 & 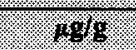 & W. & W. \\
\hline S96T001903 & 138: 2R1 & Lower $1 / 2$ & $<1,970$ & $<1,860$ & $<1,915$ & \multirow[t]{15}{*}{$<2,000$} & \multirow[t]{15}{*}{ N/A } & \multirow[t]{15}{*}{$<5,180$} \\
\hline S96T002040 & 138: $3 \mathrm{AR}$ & Whole & $<2,040$ & $<1,910$ & $<1,975$ & & & \\
\hline S96T002045 & \multirow[t]{2}{*}{$138: 6$} & Upper $1 / 2$ & $<1,920$ & $<1,890$ & $<1,905$ & & & \\
\hline S96T002047 & & Lower $1 / 2$ & $<2,070$ & $<1,910$ & $<1,990$ & & & \\
\hline S96T002193 & \multirow[t]{2}{*}{ 138: 7} & Upper $1 / 2$ & $<2,080$ & $<2,120$ & $<2,100$ & & & \\
\hline S96T002202 & & Lower $1 / 2$ & $<2,000$ & $<2,000$ & $<2,000$ & & & \\
\hline S96T002199 & 138: 9 & Lower $1 / 2$ & $<2,130$ & $<2,080$ & $<2,105$ & & & \\
\hline S96T002090 & 142: 1 & Upper $1 / 2$ & $<2,060$ & $<2,050$ & $<2,055$ & & & \\
\hline S96T002310 & \multirow[t]{2}{*}{ 142: 2} & Upper $1 / 2$ & $<1,880$ & $<1,850$ & $<1,865$ & & & \\
\hline S96T002316 & & Lower $1 / 2$ & $<2,040$ & $<2,030$ & $<2,035$ & & & \\
\hline S96T002311 & \multirow[t]{2}{*}{ 142: 3} & Upper $1 / 2$ & $<2,020$ & $<2,060$ & $<2,040$ & & & \\
\hline S96T002319 & & Lower $1 / 2$ & $<1,950$ & $<1,910$ & $<1,930$ & & & \\
\hline S96T002092 & \multirow[t]{2}{*}{ 142: 4} & Upper $1 / 2$ & $<2,020$ & $<2,000$ & $<2,010$ & & & \\
\hline S96T002105 & & Lower $1 / 2$ & $<2,000$ & $<2,060$ & $<2,030$ & & & \\
\hline S96T002093 & $142: 5$ & Upper $1 / 2$ & $<1,940$ & $<1,870$ & $<1,905$ & & & \\
\hline
\end{tabular}




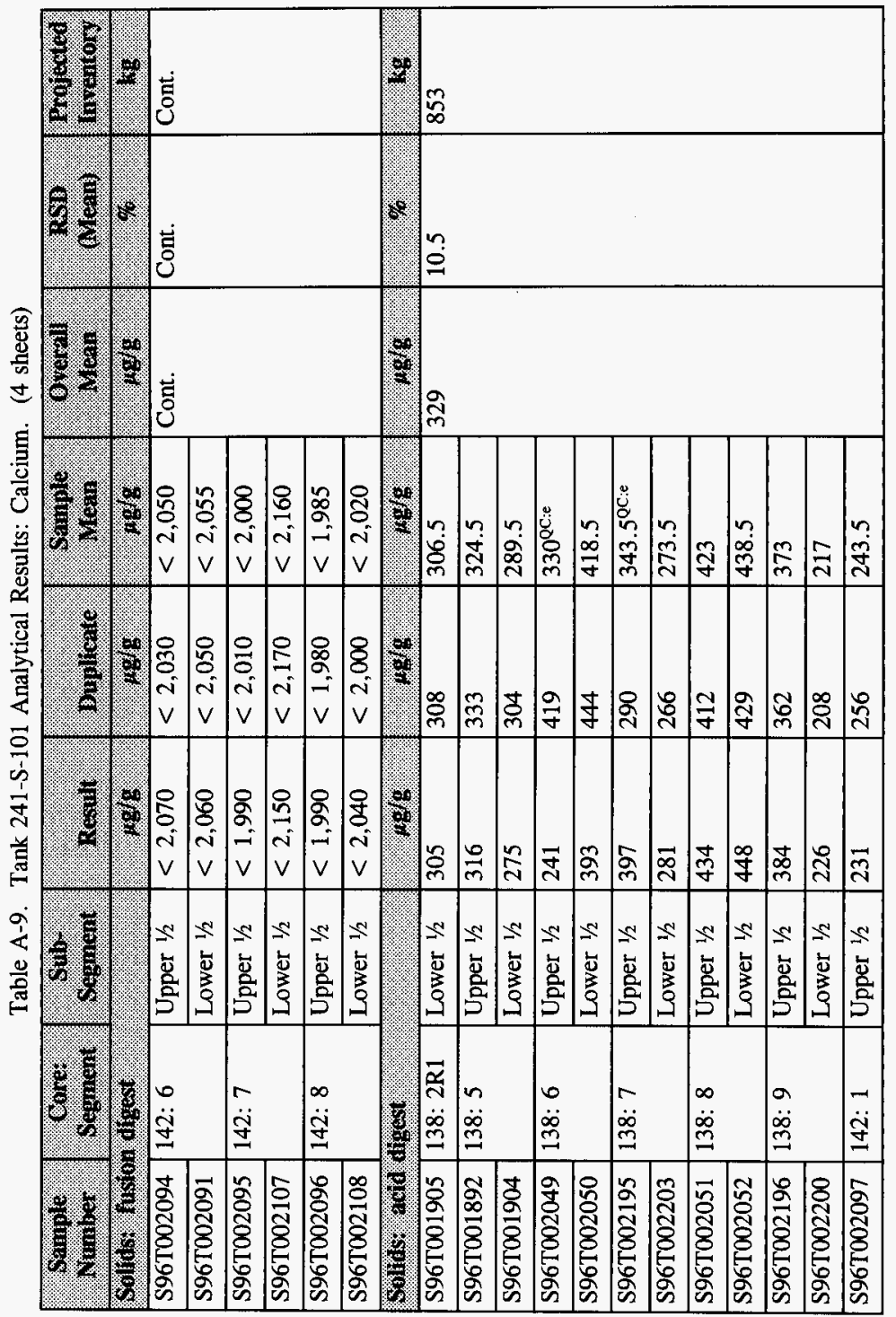


Table A-9. Tank 241-S-101 Analytical Results: Calcium. (4 sheets)

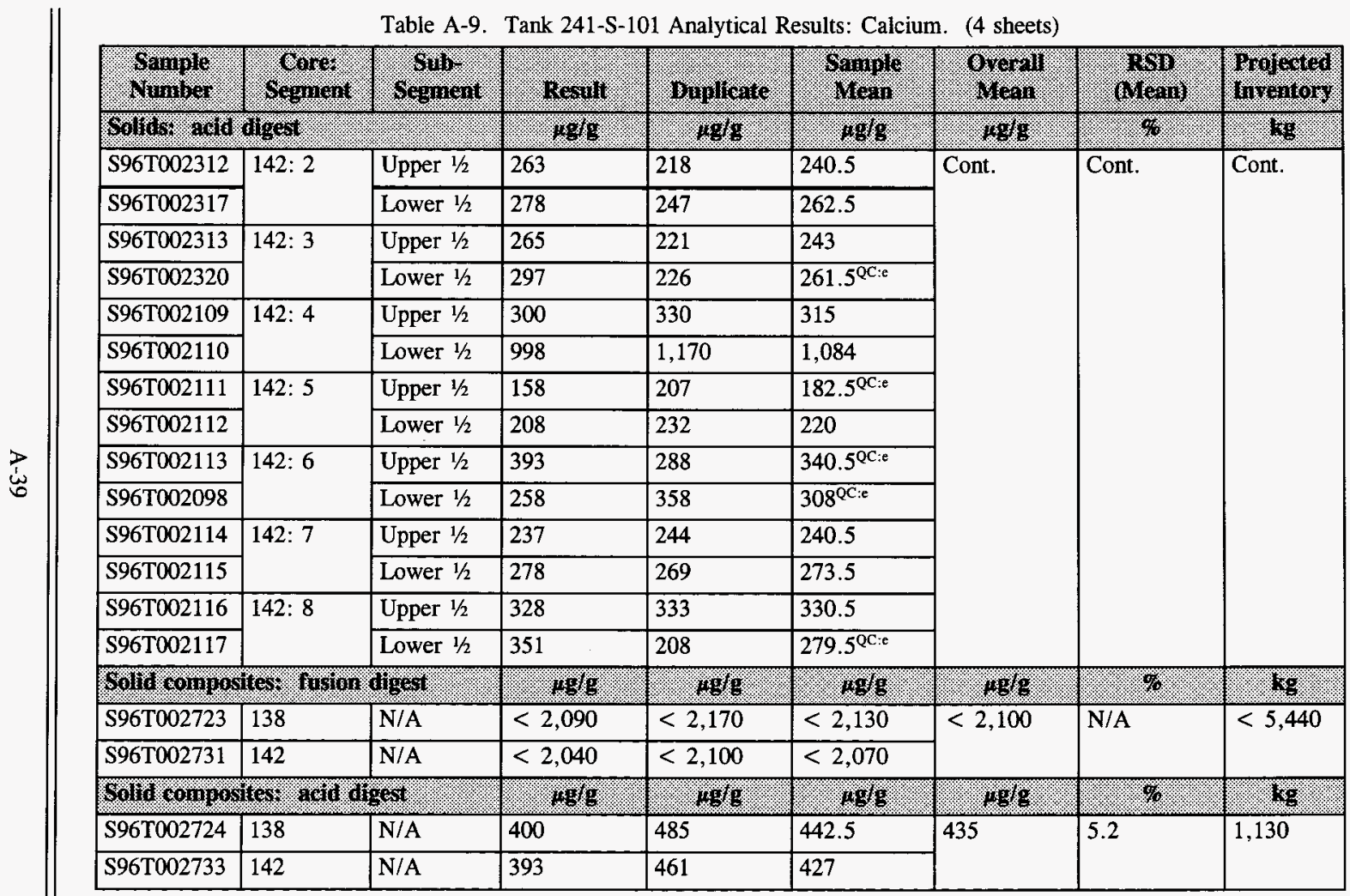


Table A-9. Tank 241-S-101 Analytical Results: Calcium. (4 sheets)

\begin{tabular}{|c|c|c|c|c|c|c|c|c|}
\hline Wrinimo & Wor & Hederich & mesinit & Buplicate & 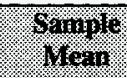 & Soril & $(1 / 2)$ & 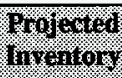 \\
\hline \multicolumn{3}{|c|}{ 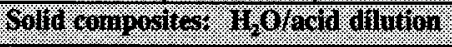 } & .998 & 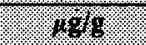 & 468 & 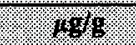 & 6 & 18 \\
\hline S96T002726 & 138 & N/A & $<56.2$ & $<54.6$ & $<55.4$ & \multirow[t]{2}{*}{$<54.0$} & \multirow[t]{2}{*}{ N/A } & \multirow[t]{2}{*}{$<140$} \\
\hline \$96T002736 & 142 & N/A & $<54.8$ & $<50.4$ & $<52.6$ & & & \\
\hline \multicolumn{3}{|c|}{ 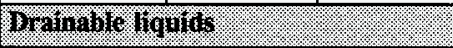 } & 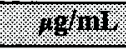 & W11. & moln & yolny. & $\%$ & 19 \\
\hline \$96T001886 & 138: $1 \mathrm{R}$ & DL & $<40.1$ & $<40.1$ & $<40.1$ & \multirow[t]{3}{*}{$<40.1$} & \multirow[t]{3}{*}{ N/A } & \multirow[t]{3}{*}{$<1.80$} \\
\hline \$96T001909 & 138: 2R1 & DL & $<40.1$ & $<40.1$ & $<40.1$ & & & \\
\hline S96T002043 & 138: $3 R$ & DL & $<40.1$ & $<40.1$ & $<40.1$ & & & \\
\hline
\end{tabular}


Table A-10. Tank 241-S-101 Analytical Results: Cerium. (4 sheets)

\begin{tabular}{|c|c|c|c|c|c|c|c|c|}
\hline Woraglo & \% & soling & ingeril & Bugleate & 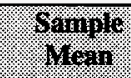 & Whon & 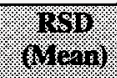 & 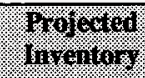 \\
\hline \multicolumn{3}{|c|}{ 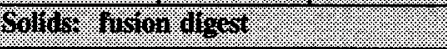 } & 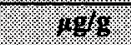 & Wots & 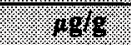 & $163 / 5 \%$ & (18. & 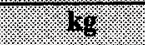 \\
\hline S96T001903 & 138: 2R1 & Lower $1 / 2$ & $<1,970$ & $<1,860$ & $<1,915$ & \multirow[t]{21}{*}{$<2,000$} & \multirow[t]{21}{*}{ N/A } & \multirow[t]{21}{*}{$<5,180$} \\
\hline S96T002040 & 138: $3 \mathrm{AR}$ & Whole & $<2,040$ & $<1,910$ & $<1,975$ & & & \\
\hline S96T001891 & \multirow[t]{2}{*}{$138: 5$} & Upper $1 / 2$ & $<2,100$ & $<2,120$ & $<2,110$ & & & \\
\hline S96T001902 & & Lower $1 / 2$ & $<1,810$ & $<1,760$ & $<1,785$ & & & \\
\hline S96T002045 & \multirow[t]{2}{*}{$138: 6$} & Upper $1 / 2$ & $<1,920$ & $<1,890$ & $<1,905$ & & & \\
\hline S96T002047 & & Lower $1 / 2$ & $<2,070$ & $<1,910$ & $<1,990$ & & & \\
\hline S96T002193 & \multirow[t]{2}{*}{ 138: 7} & Upper $1 / 2$ & $<2,080$ & $<2,120$ & $<2,100$ & & & \\
\hline S96T002202 & & Lower $1 / 2$ & $<2,000$ & $<2,000$ & $<2,000$ & & & \\
\hline S96T002046 & \multirow[t]{2}{*}{ 138: 8} & Upper $1 / 2$ & $<2,050$ & $<2,090$ & $<2,070$ & & & \\
\hline S96T002048 & & Lower $1 / 2$ & $<1,890$ & $<2,040$ & $<1,965$ & & & \\
\hline S96T002194 & \multirow[t]{2}{*}{$138: 9$} & Upper $1 / 2$ & $<1,930$ & $<2,050$ & $<1,990$ & & & \\
\hline S96T002199 & & Lower $1 / 2$ & $<2,130$ & $<2,080$ & $<2,105$ & & & \\
\hline \$96T002090 & 142: 1 & Upper $1 / 2$ & $<2,060$ & $<2,050$ & $<2,055$ & & & \\
\hline S96T002310 & \multirow[t]{2}{*}{ 142: 2} & Upper $1 / 2$ & $<1,880$ & $<1,850$ & $<1,865$ & & & \\
\hline S96T002316 & & Lower $1 / 2$ & $<2,040$ & $<2,030$ & $<2,035$ & & & \\
\hline S96T002311 & \multirow[t]{2}{*}{$142: 3$} & Upper $1 / 2$ & $<2,020$ & $<2,060$ & $<2,040$ & & & \\
\hline S96T002319 & & Lower $1 / 2$ & $<1,950$ & $<1,910$ & $<1,930$ & & & \\
\hline S96T002092 & \multirow[t]{2}{*}{$142: 4$} & Upper $1 / 2$ & $<2,020$ & $<2,000$ & $<2,010$ & & & \\
\hline S96T002105 & & Lower $1 / 2$ & $<2,000$ & $<2,060$ & $<2,030$ & & & \\
\hline S96T002093 & \multirow[t]{2}{*}{$142: 5$} & Upper $1 / 2$ & $<1,940$ & $<1,870$ & $<1,905$ & & & \\
\hline S96T002106 & & Lower $1 / 2$ & $<2,040$ & $<1,870$ & $<1,955$ & & & \\
\hline
\end{tabular}


Table A-10. Tank 241-S-101 Analytical Results: Cerium. (4 sheets)

\begin{tabular}{|c|c|c|c|c|c|c|c|c|}
\hline Mraing & orgarlent & Hotorent & Revint. & Binpilente & Monish & owaral & Wor & 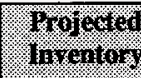 \\
\hline \multicolumn{3}{|c|}{ 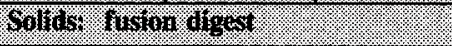 } & 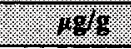 & 198 & 1018 & 1098 & $4 \%$ & 148 \\
\hline S96T002094 & \multirow[t]{2}{*}{$142: 6$} & Upper $1 / 2$ & $<2,070$ & $<2,030$ & $<2,050$ & \multirow[t]{6}{*}{ Cont. } & \multirow[t]{6}{*}{ Cont. } & \multirow[t]{6}{*}{ Cont. } \\
\hline S96T002091 & & Lower $1 / 2$ & $<2,060$ & $<2,050$ & $<2,055$ & & & \\
\hline S96T002095 & \multirow[t]{2}{*}{$142: 7$} & Upper $1 / 2$ & $<1,990$ & $<2,010$ & $<2,000$ & & & \\
\hline \$96T002107 & & Lower $1 / 2$ & $<2,150$ & $<2,170$ & $<2,160$ & & & \\
\hline S96T002096 & \multirow[t]{2}{*}{$142: 8$} & Upper $1 / 2$ & $<1,990$ & $<1,980$ & $<1,985$ & & & \\
\hline S96T002108 & & Lower $1 / 2$ & $<2,040$ & $<2,000$ & $<2,020$ & & & \\
\hline \multicolumn{3}{|c|}{ Sollts: add agest } & 40 & 4018 & 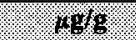 & 1488 & \% & 4 \\
\hline S96T001905 & 138: 2R1 & Lower $1 / 2$ & $<38.1$ & $<38.7$ & $<38.4$ & \multirow[t]{14}{*}{$<38.8$} & \multirow[t]{14}{*}{ N/A } & \multirow[t]{14}{*}{$<101$} \\
\hline S96T001892 & \multirow[t]{2}{*}{$138: 5$} & Upper $1 / 2$ & $<38.2$ & $<40.3$ & $<39.25$ & & & \\
\hline S96T001904 & & Lower $1 / 2$ & $<35.8$ & $<39.2$ & $<37.5$ & & & \\
\hline \$96T002049 & \multirow[t]{2}{*}{ 138: 6} & Upper $1 / 2$ & $<37.6$ & $<38.9$ & $<38.25$ & & & \\
\hline S96T002050 & & Lower $1 / 2$ & $<37.1$ & $<40.9$ & $<39$ & & & \\
\hline S96T002195 & \multirow[t]{2}{*}{ 138: 7} & Upper $1 / 2$ & $<44$ & $<44.9$ & $<44.45$ & & & \\
\hline S96T002203 & & Lower $1 / 2$ & $<39.1$ & $<40.8$ & $<39.95$ & & & \\
\hline S96T002051 & \multirow[t]{2}{*}{ 138: 8} & Upper $1 / 2$ & $<36.9$ & $<38$ & $<37.45$ & & & \\
\hline S96T002052 & & Lower $1 / 2$ & $<37.9$ & $<39.1$ & $<38.5$ & & & \\
\hline S96T002196 & \multirow[t]{2}{*}{ 138: 9} & Upper $1 / 2$ & $<36.9$ & 39.4 & $<38.15$ & & & \\
\hline \$96T002200 & & Lower $1 / 2$ & $<36.8$ & $<39.8$ & $<38.3$ & & & \\
\hline S96T002097 & 142: 1 & Upper $1 / 2$ & $<35.7$ & $<35.7$ & $<35.7$ & & & \\
\hline S96T002312 & \multirow[t]{2}{*}{ 142: 2} & Upper $1 / 2$ & $<40.9$ & $<36.8$ & $<38.85$ & & & \\
\hline S96T002317 & & Lower $1 / 2$ & $<37.3$ & $<39.1$ & $<38.2$ & & & \\
\hline
\end{tabular}


Table A-10. Tank 241-S-101 Analytical Results: Cerium. (4 sheets)

\begin{tabular}{|c|c|c|c|c|c|c|c|c|}
\hline Wamper & 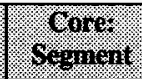 & 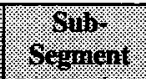 & 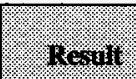 & Buplicate & Gomplo & (6) & oring & 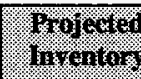 \\
\hline \multicolumn{2}{|c|}{ 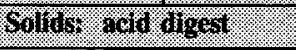 } & (1:. & 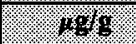 & 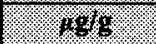 & .1996 & 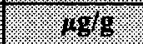 & 18. & kit \\
\hline S96T002313 & \multirow[t]{2}{*}{ 142: 3} & Upper $1 / 2$ & $<41$ & $<40.5$ & $<40.75$ & \multirow[t]{12}{*}{ Cont. } & \multirow[t]{12}{*}{ Cont. } & \multirow[t]{12}{*}{ Cont. } \\
\hline S96T002320 & & Lower $1 / 2$ & $<41.7$ & $<40.1$ & $<40.9$ & & & \\
\hline S96T002109 & \multirow[t]{2}{*}{ 142: 4} & Upper $1 / 2$ & $<40.1$ & $<40.9$ & $<40.5$ & & & \\
\hline S96T002110 & & Lower $1 / 2$ & $<39.3$ & $<38.6$ & $<38.95$ & & & \\
\hline S96T002111 & \multirow[t]{2}{*}{ 142: 5} & Upper $1 / 2$ & $<35.3$ & $<38.6$ & $<36.95$ & & & \\
\hline S96T002112 & & Lower $1 / 2$ & $<35.7$ & $<38.2$ & $<36.95$ & & & \\
\hline \$96T002113 & \multirow[t]{2}{*}{ 142: 6} & Upper $1 / 2$ & $<38.9$ & $<44.8$ & $<41.85$ & & & \\
\hline S96T002098 & & Lower $1 / 2$ & $<39.3$ & $<40.8$ & $<40.05$ & & & \\
\hline S96T002114 & \multirow[t]{2}{*}{ 142: 7} & Upper $1 / 2$ & $<39.6$ & $<40.2$ & $<39.9$ & & & \\
\hline S96T002115 & & Lower $1 / 2$ & $<36.7$ & $<35.8$ & $<36.25$ & & & \\
\hline S96T002116 & \multirow[t]{2}{*}{$142: 8$} & Upper $1 / 2$ & $<37.1$ & $<36$ & $<36.55$ & & & \\
\hline S96T002117 & & Lower $1 / 2$ & $<37.5$ & $<37$ & $<37.25$ & & & \\
\hline \multicolumn{3}{|c|}{ 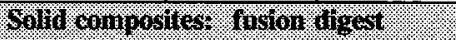 } & 1096 & 1918 & 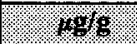 & 1818 & $\%$ & (6) \\
\hline \$96T002723 & 138 & N/A & $<2,090$ & $<2,170$ & $<2,130$ & \multirow[t]{2}{*}{$<2,100$} & \multirow[t]{2}{*}{$\mathrm{N} / \mathrm{A}$} & \multirow[t]{2}{*}{$<5,440$} \\
\hline S96T002731 & 142 & N/A & $<2,040$ & $<2,100$ & $<2,070$ & & & \\
\hline \multicolumn{3}{|c|}{ 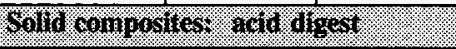 } & 1016 & 1018 & 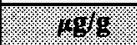 & .096 & 96 & 189 \\
\hline S96T002724 & 138 & N/A & 73.1 & $<68.2$ & $<70.65$ & \multirow[t]{2}{*}{$<68.1$} & \multirow[t]{2}{*}{ N/A } & \multirow[t]{2}{*}{$<177$} \\
\hline S96T002733 & 142 & N/A & $<67.7$ & $<63.5$ & $<65.6$ & & & \\
\hline \multicolumn{3}{|c|}{ 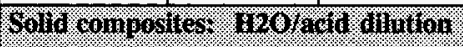 } & 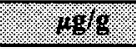 & 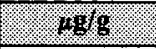 & 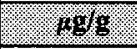 & $.10 \mathrm{gg}$ & $\sqrt{2} .96$ & (6) \\
\hline S96T002726 & 138 & N/A & $<56.2$ & $<54.6$ & $<55.4$ & \multirow[t]{2}{*}{$<54.0$} & \multirow[t]{2}{*}{ N/A } & \multirow[t]{2}{*}{$<140$} \\
\hline S96T002736 & 142 & $N / A$ & $<54.8$ & $<50.4$ & $<52.6$ & & & \\
\hline
\end{tabular}


Table A-10. Tank 241-S-101 Analytical Results: Cerium. (4 sheets)

\begin{tabular}{|c|c|c|c|c|c|c|c|c|}
\hline Whinger & 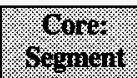 & 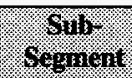 & Rrailit & 34ullate & 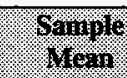 & oroul & 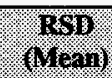 & Wrogurol \\
\hline \multicolumn{3}{|c|}{ 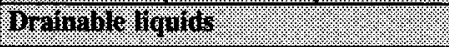 } & \% $1 \mathrm{mi}$ & .9411 & . & $49 \mathrm{~mL}$ & V. & X/ \\
\hline S96T001886 & 138: 1R & DL & $<40.1$ & $<40.1$ & $<40.1$ & \multirow[t]{3}{*}{$<40.1$} & \multirow[t]{3}{*}{$\mathrm{N} / \mathrm{A}$} & \multirow[t]{3}{*}{$<1.80$} \\
\hline S96T001909 & 138: 2R1 & $\overline{\mathrm{DL}}$ & $<40.1$ & $<40.1$ & $<40.1$ & & & \\
\hline S96T002043 & 138: 3R & DL & $<40.1$ & $<40.1$ & $<40.1$ & & & \\
\hline
\end{tabular}


WHC-SD-WM-ER-613 Rev. 0

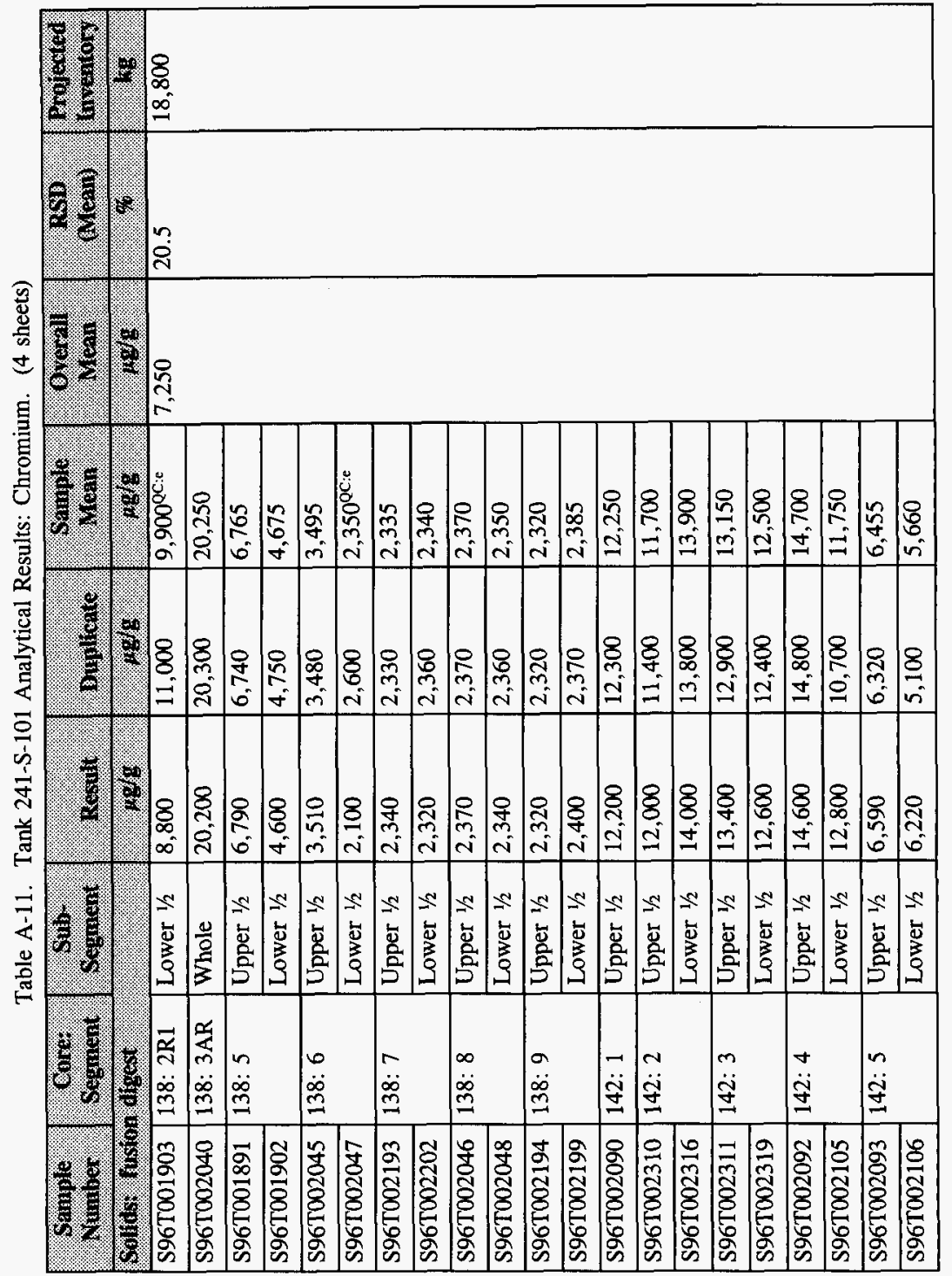


Table A-11. Tank 241-S-101 Analytical Results: Chromium. (4 sheets)

\begin{tabular}{|c|c|c|c|c|c|c|c|c|}
\hline Saruis & (1) & Gouls & Mesult & Bupleate. & 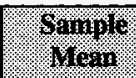 & 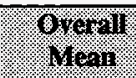 & 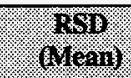 & 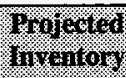 \\
\hline \multicolumn{3}{|c|}{ 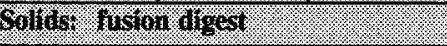 } & $148 \mathrm{y}$ & $4 \%$ & mol & 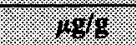 & $1 \%$. & (1) \\
\hline S96T002094 & \multirow[t]{2}{*}{ 142: 6} & Upper $1 / 2$ & 2,810 & 2,820 & 2,815 & \multirow[t]{6}{*}{ Cont. } & \multirow[t]{6}{*}{ Cont. } & \multirow[t]{6}{*}{ Cont. } \\
\hline S96T002091 & & Lower $1 / 2$ & 1,590 & 1,910 & 1,750 & & & \\
\hline S96T002095 & \multirow[t]{2}{*}{$142: 7$} & Upper $1 / 2$ & 2,060 & 2,010 & 2,035 & & & \\
\hline S96T002107 & & Lower $1 / 2$ & 1,570 & 2,080 & $1,825^{\mathrm{QC}: \mathrm{e}}$ & & & \\
\hline S96T002096 & \multirow[t]{2}{*}{ 142: 8} & Upper $1 / 2$ & 2,210 & 2,250 & 2,230 & & & \\
\hline S96T002108 & & Lower $1 / 2$ & 2,360 & 2,320 & 2,340 & & & \\
\hline \multicolumn{3}{|c|}{ Soltas: awd digedr? } & 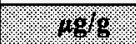 & $.16 \%$ & 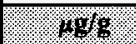 & 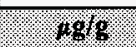 & $1 \%$ & $18 \%$ \\
\hline S96T001905 & 138: 2R1 & Lower $1 / 2$ & 6,200 & 6,330 & 6,265 & \multirow[t]{14}{*}{4,740} & \multirow[t]{14}{*}{31.6} & \multirow[t]{14}{*}{12,300} \\
\hline S96T001892 & \multirow[t]{2}{*}{$138: 5$} & Upper $1 / 2$ & 4,320 & 4,590 & 4,455 & & & \\
\hline S96T001904 & & Lower $1 / 2$ & 4,420 & 4,870 & 4,645 & & & \\
\hline S96T002049 & \multirow[t]{2}{*}{ 138: 6} & Upper $1 / 2$ & 2,840 & 2,910 & 2,875 & & & \\
\hline S96T002050 & & Lower $1 / 2$ & 2,310 & 2,280 & 2,295 & & & \\
\hline S96T002195 & \multirow[t]{2}{*}{$138: 7$} & Upper $1 / 2$ & 2,020 & 2,050 & 2,035 & & & \\
\hline S96T002203 & & Lower $1 / 2$ & 2,040 & 2,220 & 2,130 & & & \\
\hline S96T002051 & \multirow[t]{2}{*}{ 138: 8} & Upper $1 / 2$ & 2,110 & 2,080 & 2,095 & & & \\
\hline S96T002052 & & Lower $1 / 2$ & 2,080 & 2,040 & 2,060 & & & \\
\hline S96T002196 & \multirow[t]{2}{*}{$138: 9$} & Upper $1 / 2$ & 2,000 & 1,960 & 1,980 & & & \\
\hline S96T002200 & & Lower $1 / 2$ & 2,100 & 2,170 & 2,135 & & & \\
\hline S96T002097 & $142: 1$ & Upper $1 / 2$ & 10,300 & 10,200 & 10,250 & & & \\
\hline S96T002312 & \multirow[t]{2}{*}{$142: 2$} & Upper $1 / 2$ & 10,700 & $9, \overline{420}$ & 10,060 & & & \\
\hline S96T002317 & & Lower $1 / 2$ & 10,200 & 10,500 & 10,350 & & & \\
\hline
\end{tabular}


Table A-11. Tank 241-S-101 Analytical Results: Chromium. (4 sheets)

\begin{tabular}{|c|c|c|c|c|c|c|c|c|}
\hline Gample & ofonct. & ogrivient & Resill: & 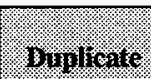 & 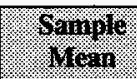 & Wholl & Mors & Trosector \\
\hline \multicolumn{3}{|c|}{ 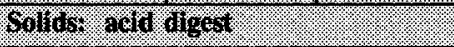 } & $.68 \mathrm{~g}$ & 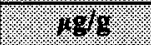 & $986 \%$ & $18 \mathrm{~g}$ & $1 \%$ & . \\
\hline S96T002313 & \multirow[t]{2}{*}{$142: 3$} & Upper $1 / 2$ & 2,430 & 2,100 & 2,265 & \multirow[t]{12}{*}{ Cont. } & \multirow[t]{12}{*}{ Cont. } & \multirow[t]{12}{*}{ Cont. } \\
\hline S96T002320 & & Lower $1 / 2$ & 9,870 & 9,840 & 9,855 & & & \\
\hline S96T002109 & \multirow[t]{2}{*}{$142: 4$} & Upper $1 / 2$ & 11,900 & 11,900 & 11,900 & & & \\
\hline S96T002110 & & Lower $1 / 2$ & 7,060 & 7,430 & 7,245 & & & \\
\hline S96T002111 & \multirow[t]{2}{*}{ 142: 5} & Upper $1 / 2$ & 2,760 & 3,880 & $3,320^{\mathrm{QC}: e}$ & & & \\
\hline S96T002112 & & Lower $1 / 2$ & 3,500 & 4,090 & 3,795 & & & \\
\hline S96T002113 & \multirow[t]{2}{*}{ 142: 6} & Upper $1 / 2$ & 9,840 & 11,300 & 10,570 & & & \\
\hline S96T002098 & & Lower $1 / 2$ & 1,560 & 2,490 & $2,025^{\mathrm{QC}: \mathrm{e}}$ & & & \\
\hline S96T002114 & \multirow[t]{2}{*}{ 142: 7} & Upper $1 / 2$ & 1,680 & 1,700 & 1,690 & & & \\
\hline S96T002115 & & Lower $1 / 2$ & 1,870 & 1,830 & 1,850 & & & \\
\hline \$96T002116 & \multirow[t]{2}{*}{ 142: 8} & Upper $1 / 2$ & 1,950 & 1,890 & 1,920 & & & \\
\hline S96T002117 & & Lower $1 / 2$ & 2,010 & 2,020 & 2,015 & & & \\
\hline \multicolumn{3}{|c|}{ 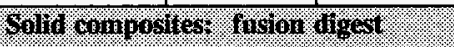 } & 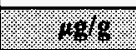 & 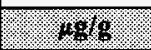 & $1.88 \%$ & $48 \%$ & $1 \%$ & 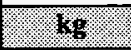 \\
\hline S96T002723 & 138 & N/A & 3,250 & 3,310 & 3,280 & \multirow[t]{2}{*}{5,230} & \multirow[t]{2}{*}{37.3} & \multirow[t]{2}{*}{13,600} \\
\hline S96T002731 & 142 & N/A & 7,050 & 7,310 & 7,180 & & & \\
\hline \multicolumn{3}{|c|}{ 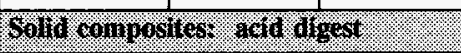 } & 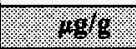 & 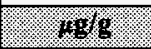 & 1498 & \% & 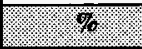 & 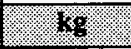 \\
\hline S96T002724 & 138 & N/A & 2,550 & 2,470 & 2,510 & \multirow[t]{2}{*}{3,300} & \multirow[t]{2}{*}{24.0} & \multirow[t]{2}{*}{8,560} \\
\hline \$96T002733 & 142 & N/A & 4,290 & 3,900 & 4,095 & & & \\
\hline \multicolumn{3}{|c|}{ 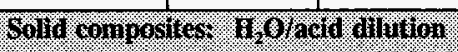 } & 6.48 & 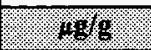 & 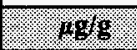 & 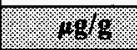 & (4. & . 19. \\
\hline S96T002726 & 138 & N/A & 2,070 & 1,900 & 1,985 & \multirow[t]{2}{*}{1,570} & \multirow[t]{2}{*}{26.4} & \multirow[t]{2}{*}{4,070} \\
\hline S96T002736 & 142 & N/A & 1,170 & 1,140 & 1,155 & & & \\
\hline
\end{tabular}




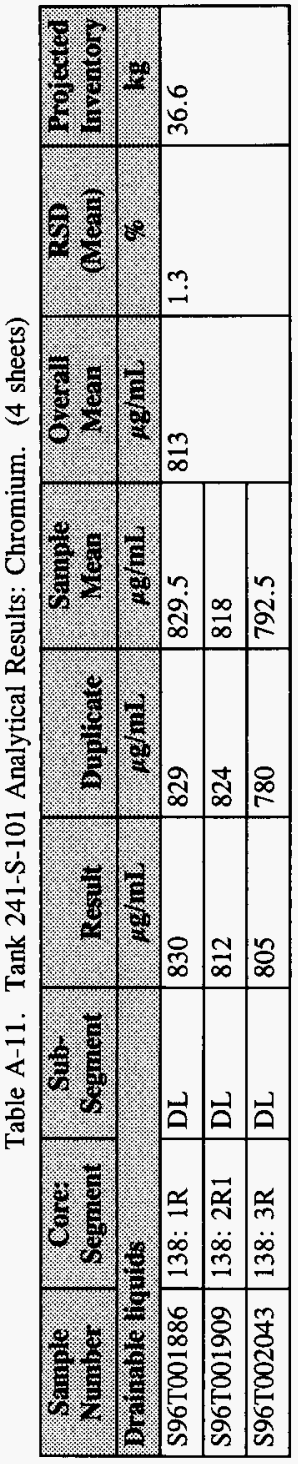


Table A-12. Tank 241-S-101 Analytical Results: Cobalt. (4 sheets)

\begin{tabular}{|c|c|c|c|c|c|c|c|c|}
\hline gomolo & 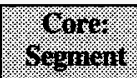 & 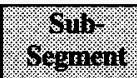 & kering & Bifulcals? & 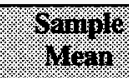 & Whoro & 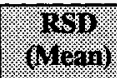 & Horom \\
\hline \multicolumn{3}{|c|}{ 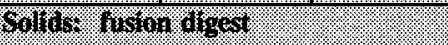 } & 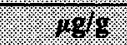 & 1819 & 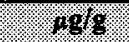 & 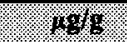 & $6 \%$ & 48 \\
\hline S96T001903 & 138: 2R1 & Lower $1 / 2$ & $<393$ & $<372$ & $<382.5$ & \multirow[t]{21}{*}{$<400$} & \multirow[t]{21}{*}{ N/A } & \multirow[t]{21}{*}{$<1,040$} \\
\hline S96T002040 & 138: $3 \mathrm{AR}$ & Whole & $<407$ & $<381$ & $<394$ & & & \\
\hline S96T001891 & \multirow[t]{2}{*}{$138: 5$} & Upper $1 / 2$ & $<420$ & $<423$ & $<421.5$ & & & \\
\hline S96T001902 & & Lower $1 / 2$ & $<363$ & $<352$ & $<357.5$ & & & \\
\hline S96T002045 & \multirow[t]{2}{*}{$138: 6$} & Upper $1 / 2$ & $<383$ & $<377$ & $<380$ & & & \\
\hline S96T002047 & & Lower $1 / 2$ & $<415$ & $<381$ & $<398$ & & & \\
\hline S96T002193 & \multirow[t]{2}{*}{ 138: 7} & Upper $1 / 2$ & $<416$ & $<425$ & $<420.5$ & & & \\
\hline S96T002202 & & Lower $1 / 2$ & $<399$ & $<401$ & $<400$ & & & \\
\hline S96T002046 & \multirow[t]{2}{*}{ 138: 8} & Upper $1 / 2$ & $<410$ & $<417$ & $<413.5$ & & & \\
\hline S96T002048 & & Lower $1 / 2$ & $<378$ & $<408$ & $<393$ & & & \\
\hline S96T002194 & \multirow[t]{2}{*}{ 138: 9} & Upper $1 / 2$ & $<385$ & $<410$ & $<397.5$ & & & \\
\hline S96T002199 & & Lower $1 / 2$ & $<425$ & $<415$ & $<420$ & & & \\
\hline S96T002090 & 142: 1 & Upper $1 / 2$ & $<411$ & $<410$ & $<410.5$ & & & \\
\hline S96T002310 & \multirow[t]{2}{*}{$142: 2$} & Upper $1 / 2$ & $<375$ & $<369$ & $<372$ & & & \\
\hline \$96T002316 & & Lower $1 / 2$ & $<408$ & $<405$ & $<406.5$ & & & \\
\hline S96T002311 & \multirow[t]{2}{*}{$142: 3$} & Upper $1 / 2$ & $<404$ & $<411$ & $<407.5$ & & & \\
\hline S96T002319 & & Lower $1 / 2$ & $<391$ & $<382$ & $<386.5$ & & & \\
\hline S96T002092 & \multirow[t]{2}{*}{ 142: 4} & Upper $1 / 2$ & $<403$ & $<399$ & $<401$ & & & \\
\hline S96T002105 & & Lower $1 / 2$ & $<399$ & $<412$ & $<405.5$ & & & \\
\hline S96T002093 & \multirow[t]{2}{*}{$142: 5$} & Upper $1 / 2$ & $<387$ & $<374$ & $<380.5$ & & & \\
\hline S96T002106 & & Lower $1 / 2$ & $<409$ & $<375$ & $<392$ & & & \\
\hline
\end{tabular}


Table A-12. Tank 241-S-101 Analytical Results: Cobalt. (4 sheets)

\begin{tabular}{|c|c|c|c|c|c|c|c|c|}
\hline Mamplo & 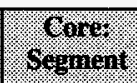 & ogoment. & ingorith & Mulicate & Wormolo & orowil & $\begin{array}{l}16 \mathrm{~s} \\
6 \mathrm{H} / 1\end{array}$ & 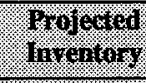 \\
\hline \multicolumn{3}{|c|}{ 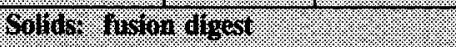 } & 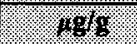 & $.48 \%$ & 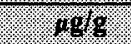 & 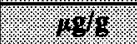 & (2.8. & 18 \\
\hline S96T002094 & \multirow[t]{2}{*}{$142: 6$} & Upper $1 / 2$ & $<415$ & $<405$ & $<410$ & \multirow[t]{6}{*}{ Cont. } & \multirow[t]{6}{*}{ Cont. } & \multirow[t]{6}{*}{ Cont. } \\
\hline S96T002091 & & Lower $1 / 2$ & $<412$ & $<409$ & $<410.5$ & & & \\
\hline S96T002095 & \multirow[t]{2}{*}{ 142: 7} & Upper $1 / 2$ & $<397$ & $<401$ & $<399$ & & & \\
\hline S96T002107 & & Lower $1 / 2$ & $<429$ & $<435$ & $<432$ & & & \\
\hline S96T002096 & \multirow[t]{2}{*}{ 142: 8} & Upper 1/2 & $<398$ & $<397$ & $<397.5$ & & & \\
\hline S96T002108 & & Lower $1 / 2$ & $<408$ & $<399$ & $<403.5$ & & & \\
\hline \multicolumn{3}{|c|}{ 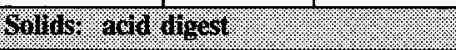 } & 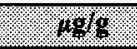 & $.8 \mathrm{~g}$ & $.7 \mathrm{~g} / \mathrm{g}$ & 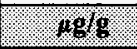 & 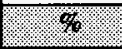 & \%.6. \\
\hline S96T001905 & 138: 2R1 & Lower $1 / 2$ & $<7.62$ & $<7.75$ & $<7.685$ & \multirow[t]{14}{*}{$<7.75$} & \multirow[t]{14}{*}{ N/A } & \multirow[t]{14}{*}{$<20.1$} \\
\hline \$96T001892 & \multirow[t]{2}{*}{$138: 5$} & Upper $1 / 2$ & $<7.64$ & $<8.05$ & $<7.845$ & & & \\
\hline S96T001904 & & Lower $1 / 2$ & $<7.16$ & $<7.84$ & $<7.5$ & & & \\
\hline S96T002049 & \multirow[t]{2}{*}{$138: 6$} & Upper $1 / 2$ & $<7.53$ & $<7.79$ & $<7.66$ & & & \\
\hline S96T002050 & & Lower $1 / 2$ & $<7.42$ & $<8.18$ & $<7.8$ & & & \\
\hline S96T002195 & \multirow[t]{2}{*}{$138: 7$} & Upper $1 / 2$ & $<8.8$ & $<8.98$ & $<8.89$ & & & \\
\hline S96T002203 & & Lower $1 / 2$ & $<7.82$ & $<8.15$ & $<7.985$ & & & \\
\hline S96T002051 & \multirow[t]{2}{*}{ 138: 8} & Upper $1 / 2$ & $<7.39$ & $<7.6$ & $<7.495$ & & & \\
\hline S96T002052 & & Lower $1 / 2$ & $<7.58$ & $<7.82$ & $<7.7$ & & & \\
\hline S96T002196 & \multirow[t]{2}{*}{ 138: 9} & Upper $1 / 2$ & $<7.38$ & $<7.28$ & $<7.33$ & & & \\
\hline S96T002200 & & Lower $1 / 2$ & $<7.36$ & $<7.96$ & $<7.66$ & & & \\
\hline \$96T002097 & $142: 1$ & Upper $1 / 2$ & $<7.15$ & $<7.15$ & $<7.15$ & & & \\
\hline S96T002312 & \multirow[t]{2}{*}{$142: 2$} & Upper $1 / 2$ & $<8.19$ & $<7.36$ & $<7.775$ & & & \\
\hline S96T002317 & & Lower $1 / 2$ & $<7.46$ & $<7.81$ & $<7.635$ & & & \\
\hline
\end{tabular}


Table A-12. Tank 241-S-101 Analytical Results: Cobalt. (4 sheets)

\begin{tabular}{|c|c|c|c|c|c|c|c|c|}
\hline Sample & \%errant & ofprant & hesolit & Biplicate & Horns & W\% & $(1061)$ & morerol \\
\hline \multicolumn{3}{|c|}{ 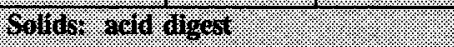 } & 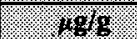 & 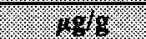 & $40 \%$ & 1698 & 96 & 68 \\
\hline S96T002313 & \multirow[t]{2}{*}{$142: 3$} & Upper $1 / 2$ & $<8.19$ & $<8.1$ & $<8.145$ & \multirow[t]{12}{*}{ Cont. } & \multirow[t]{12}{*}{ Cont. } & \multirow[t]{12}{*}{ Cont. } \\
\hline S96T002320 & & Lower $1 / 2$ & $<8.34$ & $<8.03$ & $<8.185$ & & & \\
\hline S96T002109 & \multirow[t]{2}{*}{$142: 4$} & Upper $1 / 2$ & $<8.02$ & $<8.18$ & $<8.1$ & & & \\
\hline S96T002110 & & Lower $1 / 2$ & $<7.86$ & $<7.72$ & $<7.79$ & & & \\
\hline S96T002111 & \multirow[t]{2}{*}{ 142: 5} & Upper $1 / 2$ & $<7.07$ & $<7.72$ & $<7.395$ & & & \\
\hline S96T002112 & & Lower $1 / 2$ & $<7.13$ & $<7.64$ & $<7.385$ & & & \\
\hline S96T002113 & \multirow[t]{2}{*}{ 142: 6} & Upper $1 / 2$ & $<7.79$ & $<8.95$ & $<8.37$ & & & \\
\hline S96T002098 & & Lower $1 / 2$ & $<7.86$ & $<8.16$ & $<8.01$ & & & \\
\hline S96T002114 & \multirow[t]{2}{*}{ 142: 7} & Upper $1 / 2$ & $<7.92$ & $<8.05$ & $<7.985$ & & & \\
\hline S96T002115 & & Lower $1 / 2$ & $<7.34$ & $<7.17$ & $<7.255$ & & & \\
\hline S96T002116 & \multirow[t]{2}{*}{$142: 8$} & Upper $1 / 2$ & $<7.41$ & $<7.2$ & $<7.305$ & & & \\
\hline S96T002117 & & Lower $1 / 2$ & $<7.51$ & $<7.4$ & $<7.455$ & & & \\
\hline \multicolumn{3}{|c|}{ 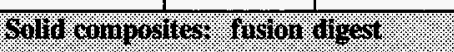 } & 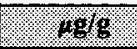 & 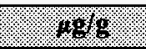 & 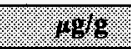 & 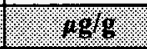 & 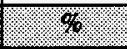 & 1.16 \\
\hline S96T002723 & 138 & N/A & $<418$ & $<434$ & $<426$ & \multirow[t]{2}{*}{$<420$} & \multirow[t]{2}{*}{ N/A } & \multirow[t]{2}{*}{$<1,090$} \\
\hline S96T002731 & 142 & N/A & $<408$ & $<421$ & $<414.5$ & & & \\
\hline \multicolumn{3}{|c|}{ 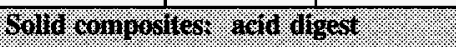 } & 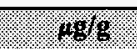 & 6.696 & $190 \%$ & 189 & 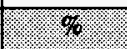 & 168 \\
\hline \$96T002724 & 138 & N/A & $<13.7$ & $<13.6$ & $<13.65$ & \multirow[t]{2}{*}{$<13.4$} & \multirow[t]{2}{*}{ N/A } & \multirow[t]{2}{*}{$<34.7$} \\
\hline S96T002733 & 142 & N/A & $<13.5$ & $<12.7$ & $<13.1$ & & & \\
\hline \multicolumn{3}{|c|}{ 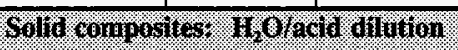 } & 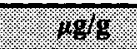 & 4.918 & 1038 & 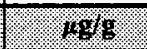 & \% & 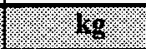 \\
\hline S96T002726 & 138 & N/A & $<11.2$ & $<10.9$ & $<11.05$ & \multirow[t]{2}{*}{$<10.8$} & \multirow[t]{2}{*}{ N/A } & \multirow[t]{2}{*}{$<28.0$} \\
\hline \$96T002736 & 142 & N/A & $<11$ & $<10.1$ & $<10.55$ & & & \\
\hline
\end{tabular}


Table A-12. Tank 241-S-101 Analytical Results: Cobalt. (4 sheets)

\begin{tabular}{|c|c|c|c|c|c|c|c|c|}
\hline Waraula & 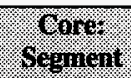 & 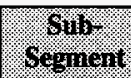 & Rerull. & Binulicalse & 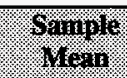 & hor & 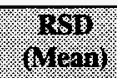 & 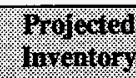 \\
\hline \multicolumn{2}{|c|}{ 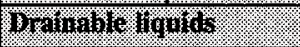 } & & (19) & 6rin & $9.86 \mathrm{nil}$ & $8 \%$ & 6 & Kg \\
\hline S96T001886 & 138: 1R & DL & $<8.02$ & $<8.02$ & $<8.02$ & \multirow[t]{3}{*}{$<8.02$} & \multirow[t]{3}{*}{ N/A } & \multirow[t]{3}{*}{$<0.361$} \\
\hline S96T001909 & 138: $2 \mathrm{RI}$ & $\mathrm{DL}$ & $<8.02$ & $<8.02$ & $<8.02$ & & & \\
\hline S96T002043 & 138: $3 \mathrm{R}$ & $\mathrm{DL}$ & $<8.02$ & $<8.02$ & $<8.02$ & & & \\
\hline
\end{tabular}


Table A-13. Tank 241-S-101 Analytical Results: Copper. (4 sheets)

\begin{tabular}{|c|c|c|c|c|c|c|c|c|}
\hline Gamis & 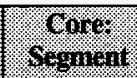 & Somol & Whan & bullorte & Shin & $46 \mathrm{sen}$ & 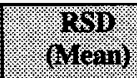 & prosm \\
\hline \multicolumn{3}{|c|}{ 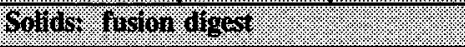 } & $w_{4}$ & 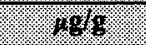 & 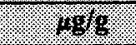 & $6 \%$ & $\sqrt{10}$ & 618 \\
\hline S96T001903 & 138: 2R1 & Lower $1 / 2$ & $<197$ & $<186$ & $<191.5$ & \multirow[t]{21}{*}{$<206$} & \multirow[t]{21}{*}{ N/A } & \multirow[t]{21}{*}{$<534$} \\
\hline S96T002040 & 138: 3AR & Whole & $<204$ & $<191$ & $<197.5$ & & & \\
\hline S96T001891 & \multirow[t]{2}{*}{ 138: 5} & Upper $1 / 2$ & $<210$ & $<212$ & $<211$ & & & \\
\hline S96T001902 & & Lower $1 / 2$ & $<181$ & $<176$ & $<178.5$ & & & \\
\hline S96T002045 & \multirow[t]{2}{*}{$138: 6$} & Upper $1 / 2$ & 520 & $<189$ & $354.5^{\mathrm{QC}: \mathrm{c}}$ & & & \\
\hline S96T002047 & & Lower $1 / 2$ & $<207$ & $<191$ & $<199$ & & & \\
\hline S96T002193 & \multirow[t]{2}{*}{ 138: 7} & Upper $1 / 2$ & $<208$ & $<212$ & $<210$ & & & \\
\hline \$96T002202 & & Lower $1 / 2$ & $<200$ & $<200$ & $<200$ & & & \\
\hline S96T002046 & \multirow[t]{2}{*}{ 138: 8} & Upper $1 / 2$ & $<205$ & $<209$ & $<207$ & & & \\
\hline S96T002048 & & Lower $1 / 2$ & $<189$ & $<204$ & $<196.5$ & & & \\
\hline S96T002194 & \multirow[t]{2}{*}{ 138: 9} & Upper $1 / 2$ & $<193$ & $<205$ & $<199$ & & & \\
\hline S96T002199 & & Lower $1 / 2$ & $<213$ & $<208$ & $<210.5$ & & & \\
\hline \$96T002090 & 142: 1 & Upper $1 / 2$ & $<206$ & $<205$ & $<205.5$ & & & \\
\hline \$96T002310 & \multirow[t]{2}{*}{$142: 2$} & Upper $1 / 2$ & $<188$ & $<185$ & $<186.5$ & & & \\
\hline S96T002316 & & Lower $1 / 2$ & $<204$ & $<203$ & $<203.5$ & & & \\
\hline S96T002311 & \multirow[t]{2}{*}{$142: 3$} & Upper $1 / 2$ & $<202$ & $<206$ & $<204$ & & & \\
\hline S96T002319 & & Lower $1 / 2$ & $<195$ & $<191$ & $<193$ & & & \\
\hline S96T002092 & \multirow[t]{2}{*}{ 142: 4} & Upper $1 / 2$ & $<202$ & $<200$ & $<201$ & & & \\
\hline S96T002105 & & Lower $1 / 2$ & $<200$ & $<206$ & $<203$ & & & \\
\hline S96T002093 & \multirow[t]{2}{*}{ 142: 5} & Upper $1 / 2$ & $<194$ & $<187$ & $<190.5$ & & & \\
\hline \$96T002106 & & Lower $1 / 2$ & $<204$ & $<187$ & $<195.5$ & & & \\
\hline
\end{tabular}


Table A-13. Tank 241-S-101 Analytical Results: Copper. (4 sheets)

\begin{tabular}{|c|c|c|c|c|c|c|c|c|}
\hline Wantor & ()$\left._{0}\right)$ & 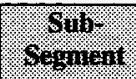 & 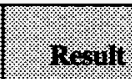 & ouplicate & 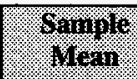 & Whatil & $\begin{array}{l}\text { (w) } \\
(1 / 291)\end{array}$ & Wrow \\
\hline \multicolumn{3}{|c|}{ 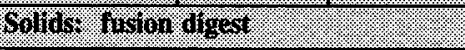 } & $18 \%$ & .9618. & $10 \%$ & $118 \%$ & ( 10.6 & 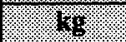 \\
\hline S96T002094 & \multirow[t]{2}{*}{ 142: 6} & Upper $1 / 2$ & $<207$ & $<203$ & $<205$ & \multirow[t]{6}{*}{ Cont. } & \multirow[t]{6}{*}{ Cont. } & \multirow[t]{6}{*}{ Cont. } \\
\hline S96T002091 & & Lower $1 / 2$ & $<206$ & $<205$ & $<205.5$ & & & \\
\hline S96T002095 & \multirow[t]{2}{*}{ 142: 7} & Upper $1 / 2$ & $<199$ & $<201$ & $<200$ & & & \\
\hline S96T002107 & & Lower $1 / 2$ & $<215$ & $<217$ & $<216$ & & & \\
\hline S96T002096 & \multirow[t]{2}{*}{$142: 8$} & Upper $1 / 2$ & $<199$ & $<198$ & $<198.5$ & & & \\
\hline S96T002108 & & Lower $1 / 2$ & $<204$ & $<200$ & $<202$ & & & \\
\hline \multicolumn{2}{|c|}{ 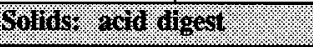 } & 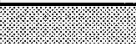 & $.48 / 8$ & . $160 \%$ & $18 \%$ & 496 & (3) & $1 \%$ \\
\hline \$96T001905 & 138: $2 \mathrm{R} 1$ & Lower $1 / 2$ & 7.76 & 7.87 & 7.815 & \multirow[t]{14}{*}{12.7} & \multirow[t]{14}{*}{21.4} & \multirow[t]{14}{*}{32.9} \\
\hline S96T001892 & \multirow[t]{2}{*}{$138: 5$} & Upper $1 / 2$ & 8.75 & 9.18 & 8.965 & & & \\
\hline S96T001904 & & Lower $1 / 2$ & 5.86 & 6.14 & 6.00 & & & \\
\hline S96T002049 & \multirow[t]{2}{*}{ 138: 6} & Upper $1 / 2$ & 8.49 & 8.9 & 8.695 & & & \\
\hline S96T002050 & & Lower $1 / 2$ & 11.6 & 26.5 & $19.05^{\mathrm{QC}: \mathrm{e}}$ & & & \\
\hline S96T002195 & \multirow[t]{2}{*}{ 138: 7} & Upper $1 / 2$ & 17.6 & 15.7 & 16.65 & & & \\
\hline S96T002203 & & Lower $1 / 2$ & 14.9 & 16.6 & 15.75 & & & \\
\hline \$96T002051 & \multirow[t]{2}{*}{$138: 8$} & Upper $1 / 2$ & 16.8 & 20.6 & 18.7 & & & \\
\hline S96T002052 & & Lower $1 / 2$ & 25.4 & 25.5 & 25.45 & & & \\
\hline \$96T002196 & \multirow[t]{2}{*}{ 138: 9} & Upper $1 / 2$ & $\overline{30.3}$ & 30.8 & 30.55 & & & \\
\hline S96T002200 & & Lower $1 / 2$ & 13.7 & 14.3 & 14 & & & \\
\hline S96T002097 & 142: 1 & Upper $1 / 2$ & $<3.57$ & 4.16 & 3.865 & & & \\
\hline S96T002312 & \multirow[t]{2}{*}{ 142: 2} & Upper $1 / 2$ & 9.72 & $<3.68$ & $6.7^{\mathrm{QC}: \mathrm{e}}$ & & & \\
\hline S96T002317 & & Lower $1 / 2$ & $<3.73$ & $<3.91$ & $<3.82$ & & & \\
\hline
\end{tabular}


Table A-13. Tank 241-S-101 Analytical Results: Copper. (4 sheets)

\begin{tabular}{|c|c|c|c|c|c|c|c|c|}
\hline Manim & 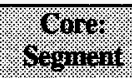 & Solit & $2.63 .11 \%$ & Bupleste & Squn & ordell & $\begin{array}{l}201 \\
(1021)\end{array}$ & 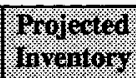 \\
\hline \multicolumn{2}{|c|}{ 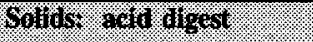 } & & $18 \% 8$ & 16818 & 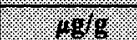 & 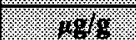 & 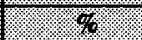 & 16: \\
\hline S96T002313 & \multirow[t]{2}{*}{ 142: 3} & Upper $1 / 2$ & 7.24 & 7.76 & 7.5 & \multirow[t]{12}{*}{ Cont. } & \multirow[t]{12}{*}{ Cont. } & \multirow[t]{12}{*}{ Cont. } \\
\hline S96T002320 & & Lower $1 / 2$ & $<4.17$ & $<4.01$ & $<4.09$ & & & \\
\hline S96T002109 & \multirow[t]{2}{*}{$142: 4$} & Upper $1 / 2$ & $<4.01$ & 6.29 & $5.15^{\mathrm{OC}: \mathrm{e}}$ & & & \\
\hline S96T002110 & & Lower $1 / 2$ & 11 & 6.89 & $8.945^{\mathrm{QC}: \mathrm{e}}$ & & & \\
\hline S96T002111 & \multirow[t]{2}{*}{$142: 5$} & Upper $1 / 2$ & 5.3 & 8.89 & $7.095^{\mathrm{QC}: \mathrm{e}}$ & & & \\
\hline S96T002112 & & Lower $1 / 2$ & 10.7 & 8.84 & 9.77 & & & \\
\hline S96T002113 & \multirow[t]{2}{*}{ 142: 6} & Upper $1 / 2$ & $<3.89$ & $<4.48$ & $<4.185$ & & & \\
\hline S96T002098 & & Lower $1 / 2$ & 28.9 & 25.5 & 27.2 & & & \\
\hline S96T002114 & \multirow[t]{2}{*}{$142: 7$} & Upper $1 / 2$ & 16.6 & 16.2 & 16.4 & & & \\
\hline S96T002115 & & Lower $1 / 2$ & 18.6 & 18.3 & 18.45 & & & \\
\hline S96T002116 & \multirow[t]{2}{*}{ 142: 8} & Upper $1 / 2$ & 19.1 & 18.6 & 18.85 & & & \\
\hline S96T002117 & & Lower $1 / 2$ & 11.2 & 9.15 & 10.175 & & & \\
\hline \multicolumn{3}{|c|}{ 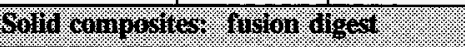 } & $16 \% 8$ & 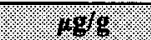 & 1480 & 1.86 & $\%$ & $1 \%$ \\
\hline S96T002723 & 138 & N/A & $<209$ & $<217$ & $<213$ & \multirow[t]{2}{*}{$<210$} & \multirow[t]{2}{*}{ N/A } & \multirow[t]{2}{*}{$<544$} \\
\hline S96T002731 & 142 & N/A & $<204$ & $<210$ & $<207$ & & & \\
\hline \multicolumn{3}{|c|}{ 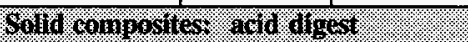 } & 140 & $169 / 9$ & 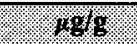 & nog/g. & 6 & 48 \\
\hline S96T002724 & 138 & N/A & 18.6 & 17.2 & 17.9 & \multirow[t]{2}{*}{15.2} & \multirow[t]{2}{*}{18.0} & \multirow[t]{2}{*}{39.4} \\
\hline S96T002733 & 142 & N/A & 13.4 & 11.5 & 12.45 & & & \\
\hline \multicolumn{3}{|c|}{ 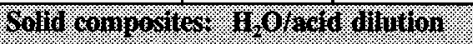 } & $6.16 \%$ & $169 \%$ & $6 \%$ & W. & 16. & 48 \\
\hline S96T002726I & 138 & N/A & $<5.62$ & $<5.46$ & $<5.54$ & \multirow[t]{2}{*}{$<5.40$} & \multirow[t]{2}{*}{ N/A } & \multirow[t]{2}{*}{1.40} \\
\hline S96T002736I & 142 & N/A & $<5.48$ & $<5.04$ & $<5.26$ & & & \\
\hline
\end{tabular}




\begin{tabular}{|c|c|c|c|c|c|c|c|c|}
\hline & & & $10^{\circ} t>$ & $10 *>$ & $10 \%>$ & $\mathrm{Td}$ & $\mathrm{XE}: 8 \mathcal{E} \mathrm{I}$ & વE†0z00L96S \\
\hline & & & $10^{\circ} t>$ & {$\left[0^{\circ} t>\right.$} & I0. $t>$ & $\mathrm{Td}$ & I\&Z :8EI & đ606I00L96S \\
\hline $08 \mathrm{I}^{\circ} 0>$ & $\forall / N$ & $10^{\circ} t>$ & $10^{\circ} t>$ & $10^{\circ} t>$ & $10^{\circ} t>$ & 7व & $\mathrm{gI}: 8 \mathcal{E}$ & G988I00.L96S \\
\hline 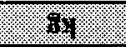 & $16.1 \%$ & Tur & Muin & mororit: & Ww: & \multicolumn{3}{|c|}{ 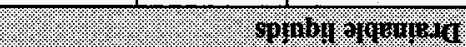 } \\
\hline $10 \% 310 \%$ & $\left(6 x_{10}\right.$ & $10 \% 1 \%$ & 11014 & 010011) & WHO 1 & 1exising & $19010 \%$ & hanim \\
\hline
\end{tabular}

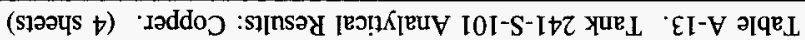




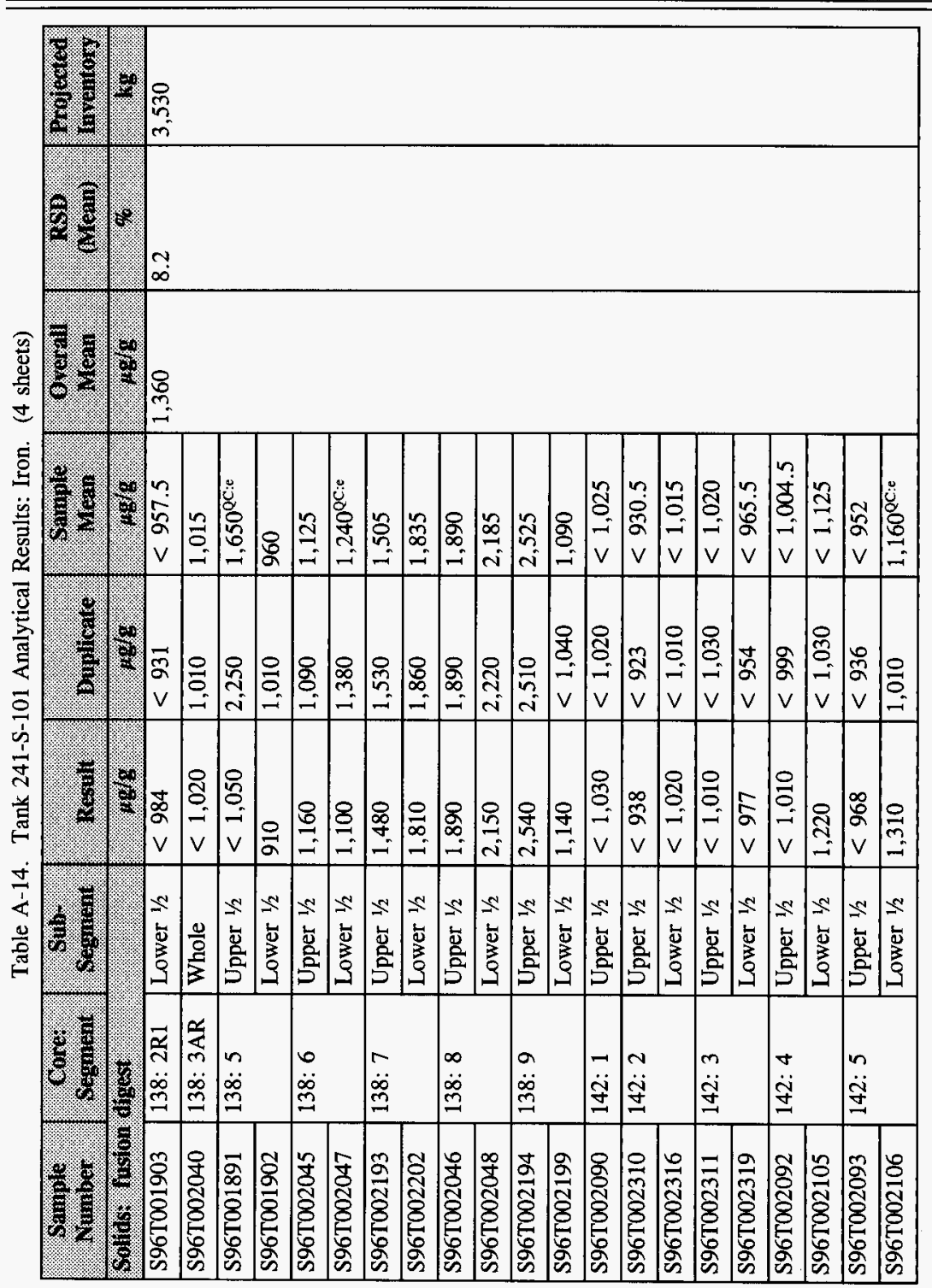


WHC-SD-WM-ER-613 Rev. 0

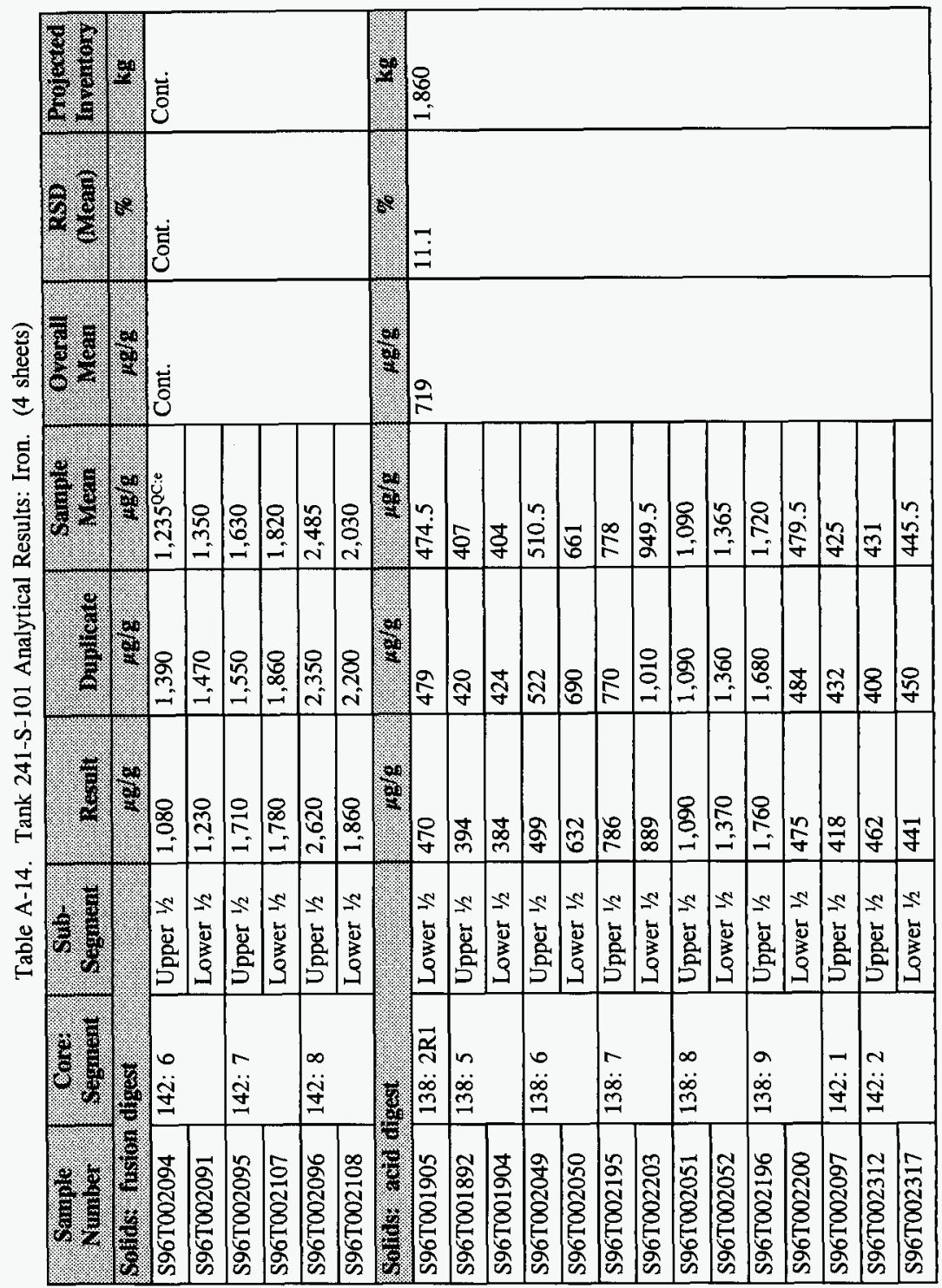


Table A-14. Tank 241-S-101 Analytical Results: Iron. (4 sheets)

\begin{tabular}{|c|c|c|c|c|c|c|c|c|}
\hline Somalo & 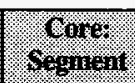 & 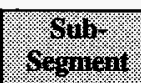 & (1) & Hinlicate & \%amil & horral & 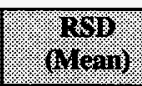 & 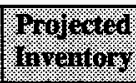 \\
\hline \multicolumn{3}{|c|}{ 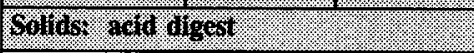 } & wor & 1.48 & 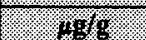 & $4 \% \%$ & $1.6 \%$ & 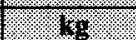 \\
\hline S96T002313 & 142: 3 & Upper $1 / 2$ & 617 & 591 & 604 & \multirow[t]{12}{*}{ Cont. } & \multirow[t]{12}{*}{ Cont. } & \multirow[t]{12}{*}{ Cont. } \\
\hline S96T002320 & & Lower $1 / 2$ & 435 & 424 & 429.5 & & & \\
\hline S96T002109 & \multirow[t]{2}{*}{ 142: 4} & Upper $1 / 2$ & 478 & 504 & 491 & & & \\
\hline S96T002110 & & Lower $1 / 2$ & 648 & 667 & 657.5 & & & \\
\hline S96T002111 & \multirow[t]{2}{*}{ 142: 5} & Upper $1 / 2$ & 265 & 361 & $313^{\mathrm{QC}: c}$ & & & \\
\hline S96T002112 & & Lower $1 / 2$ & 466 & 533 & 499.5 & & & \\
\hline \$96T002113 & \multirow[t]{2}{*}{$142: 6$} & Upper $1 / 2$ & 411 & 478 & 444.5 & & & \\
\hline S96T002098 & & Lower $1 / 2$ & 873 & 1,690 & $1,281.5^{\text {QC:e }}$ & & & \\
\hline \$96T002114 & \multirow[t]{2}{*}{$142: 7$} & Upper $1 / 2$ & 798 & 845 & 821.5 & & & \\
\hline S96T002115 & & Lower $1 / 2$ & 1,160 & 1,090 & 1,125 & & & \\
\hline S96T002116 & \multirow[t]{2}{*}{ 142: 8} & Upper $1 / 2$ & 1,380 & 1,300 & 1,340 & & & \\
\hline \$96T002117 & & Lower $1 / 2$ & 930 & 763 & 846.5 & & & \\
\hline \multicolumn{3}{|c|}{ 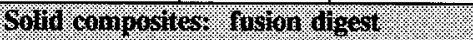 } & 1498 & $.18 \mathrm{~g}$ & $19 \%$ & 1018 & 16. & (6) \\
\hline S96T002723 & 138 & N/A & 1,400 & 1,330 & 1,365 & \multirow[t]{2}{*}{1,200} & \multirow[t]{2}{*}{13.8} & \multirow[t]{2}{*}{3,110} \\
\hline S96T002731 & 142 & N/A & $<1,020$ & $<1,050$ & $<1,035$ & & & \\
\hline \multicolumn{3}{|c|}{ 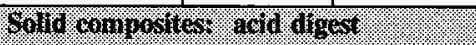 } & 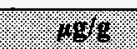 & 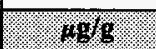 & 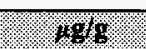 & 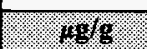 & 18. & ( \\
\hline S96T002724 & 138 & N/A & 802 & 761 & 781.5 & \multirow[t]{2}{*}{736} & \multirow[t]{2}{*}{6.1} & \multirow[t]{2}{*}{1,910} \\
\hline S96T002733 & 142 & N/A & 727 & 655 & 691 & & & \\
\hline \multicolumn{3}{|c|}{ 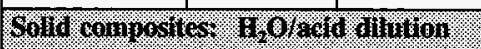 } & .489 & 2.968 & $.40 / 9$ & 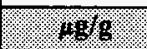 & \%. & 48 \\
\hline S96T002726I & 138 & N/A & $<28.1$ & $<27.3$ & $<27.7$ & \multirow[t]{2}{*}{$<27.0$} & \multirow[t]{2}{*}{$\mathrm{N} / \mathrm{A}$} & \multirow[t]{2}{*}{$<70.0$} \\
\hline S96T002736I & 142 & N/A & $<27.4$ & $<25.2$ & $<26.3$ & & & \\
\hline
\end{tabular}




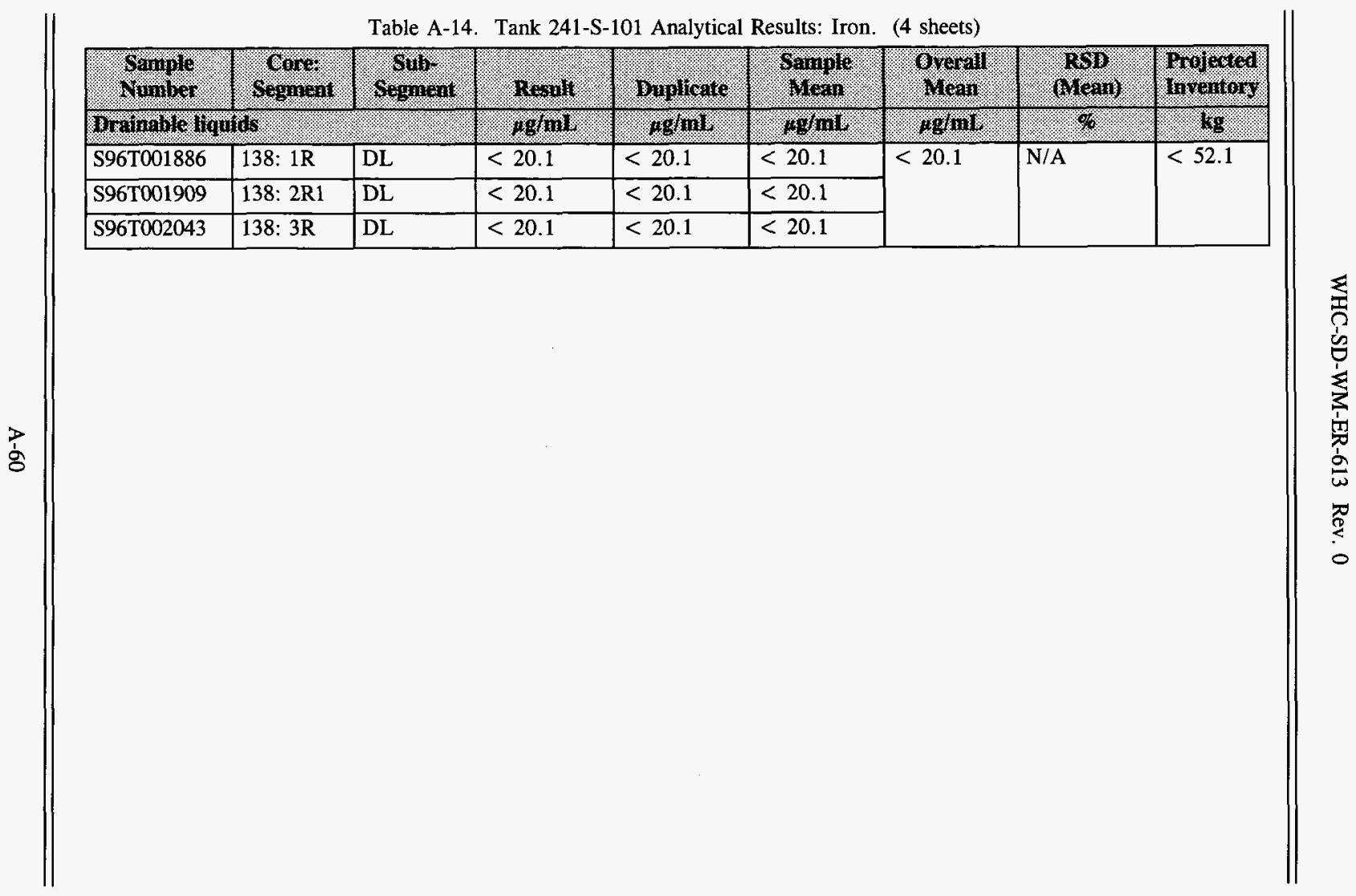




\begin{tabular}{|c|c|c|c|c|c|c|c|c|}
\hline Minnol & Wegaringit & 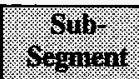 & . & Bintionte & ofamis & orean & (Nob) & 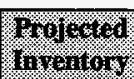 \\
\hline \multicolumn{3}{|c|}{ 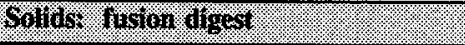 } & 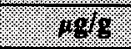 & 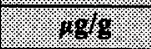 & $1.106 \mathrm{~g}$. & $18 \%$ & 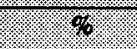 & I. \\
\hline \$96T001903 & 138: 2R1 & Lower $1 / 2$ & $<984$ & $<931$ & $<957.5$ & \multirow[t]{21}{*}{$<999$} & \multirow[t]{21}{*}{ N/A } & \multirow[t]{21}{*}{$<2,590$} \\
\hline S96T002040 & 138: $3 \mathrm{AR}$ & Whole & $<1,020$ & $<954$ & $<987$ & & & \\
\hline S96T001891 & \multirow[t]{2}{*}{$138: 5$} & Upper $1 / 2$ & $<1,050$ & $<1,060$ & $<1,055$ & & & \\
\hline S96T001902 & & Lower $1 / 2$ & $<907$ & $<880$ & $<893.5$ & & & \\
\hline S96T002045 & \multirow[t]{2}{*}{$138: 6$} & Upper $1 / 2$ & $<959$ & $<943$ & $<951$ & & & \\
\hline S96T002047 & & Lower $1 / 2$ & $<1,040$ & $<953$ & $<996.5$ & & & \\
\hline S96T002193 & \multirow[t]{2}{*}{ 138: 7} & Upper $1 / 2$ & $<1,040$ & $<1,060$ & $<1,050$ & & & \\
\hline \$96T002202 & & Lower $1 / 2$ & $<998$ & $<1,000$ & $<999$ & & & \\
\hline S96T002046 & \multirow[t]{2}{*}{ 138: 8} & Upper $1 / 2$ & $<1,030$ & $<1,040$ & $<1,035$ & & & \\
\hline S96T002048 & & Lower $1 / 2$ & $<946$ & $<1,020$ & $<983$ & & & \\
\hline S96T002194 & \multirow[t]{2}{*}{ 138: 9} & Upper $1 / 2$ & $<963$ & $<1,020$ & $<991.5$ & & & \\
\hline S96T002199 & & Lower $1 / 2$ & $<1,060$ & $<1,040$ & $<1,050$ & & & \\
\hline S96T002090 & 142: 1 & Upper $1 / 2$ & $<1,030$ & $<1,020$ & $<1,025$ & & & \\
\hline S96T002310 & \multirow[t]{2}{*}{ 142: 2} & Upper $1 / 2$ & $<938$ & $<923$ & $<930.5$ & & & \\
\hline S96T002316 & & Lower $1 / 2$ & $<1,020$ & $<1,010$ & $<1,015$ & & & \\
\hline \$96T002311 & \multirow[t]{2}{*}{ 142: 3} & Upper $1 / 2$ & $<1,010$ & $<1,030$ & $<1,020$ & & & \\
\hline S96T002319 & & Lower $1 / 2$ & $<977$ & $<954$ & $<965.5$ & & & \\
\hline S96T002092 & \multirow[t]{2}{*}{ 142: 4} & Upper $1 / 2$ & $<1,010$ & $<999$ & $<1,004.5$ & & & \\
\hline S96T002105 & & Lower $1 / 2$ & $<998$ & $<1,030$ & $<1,014$ & & & \\
\hline \$96T002093 & \multirow[t]{2}{*}{$142: 5$} & Upper $1 / 2$ & $<968$ & $<936$ & $<952$ & & & \\
\hline S96T002106 & & Lower $1 / 2$ & $<1,020$ & $<936$ & $<978$ & & & \\
\hline
\end{tabular}


Table A-15. Tank 241-S-101 Analytical Results: Lanthanum. (4 sheets)

\begin{tabular}{|c|c|c|c|c|c|c|c|c|}
\hline Sampe & Nochorint & 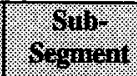 & Ir. & Buijlicale & Maringe & oxylus & $\begin{array}{c}(1 \times B) \\
(4001)\end{array}$ & Woutura \\
\hline \multicolumn{3}{|c|}{ 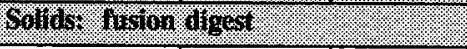 } & 1.018 & $1.196 \%$ & 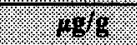 & $110 \%$ & 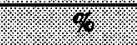 & (1) $/ 8$ \\
\hline S96T002094 & \multirow[t]{2}{*}{$142: 6$} & Upper $1 / 2$ & $<1,040$ & $<1,010$ & $<1,025$ & \multirow[t]{6}{*}{ Cont. } & \multirow[t]{6}{*}{ Cont. } & \multirow[t]{6}{*}{ Cont. } \\
\hline S96T002091 & & Lower $1 / 2$ & $<1,030$ & $<1,020$ & $<1,025$ & & & \\
\hline S96T002095 & \multirow[t]{2}{*}{ 142: 7} & Upper $1 / 2$ & $<993$ & $<1,000$ & $<996.5$ & & & \\
\hline S96T002107 & & Lower $1 / 2$ & $<1,070$ & $<1,090$ & $<1,080$ & & & \\
\hline S96T002096 & \multirow[t]{2}{*}{$142: 8$} & Upper $1 / 2$ & $<995$ & $<991$ & $<993$ & & & \\
\hline S96T002108 & & Lower $1 / 2$ & $<1,020$ & $<998$ & $<1,009$ & & & \\
\hline \multicolumn{3}{|c|}{ Soling ow digert } & $1.49 / 8$ & 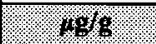 & .14869 & 496 & (8) & 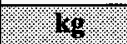 \\
\hline S96T001905 & 138: 2RI & Lower $1 / 2$ & $<19.1$ & $<19.4$ & $<19.25$ & \multirow[t]{14}{*}{$<19.6$} & \multirow[t]{14}{*}{ N/A } & \multirow[t]{14}{*}{$<50.8$} \\
\hline S96T001892 & \multirow[t]{2}{*}{ 138: 5} & Upper $1 / 2$ & $<19.1$ & $<20.1$ & $<19.6$ & & & \\
\hline S96T001904 & & Lower $1 / 2$ & $<17.9$ & $<19.6$ & $<18.75$ & & & \\
\hline S96T002049 & \multirow[t]{2}{*}{ 138: 6} & Upper $1 / 2$ & $<18.8$ & $<19.5$ & $<19.15$ & & & \\
\hline S96T002050 & & Lower $1 / 2$ & $<18.5$ & $<20.4$ & $<19.45$ & & & \\
\hline \$96T002195 & \multirow[t]{2}{*}{ 138: 7} & Upper $1 / 2$ & $<22$ & $<22.5$ & $<22.25$ & & & \\
\hline S96T002203 & & Lower $1 / 2$ & $<19.6$ & $<20.4$ & $<20$ & & & \\
\hline S96T002051 & \multirow[t]{2}{*}{ 138: 8} & Upper $1 / 2$ & $<18.5$ & $<19$ & $<18.75$ & & & \\
\hline S96T002052 & & Lower $1 / 2$ & $<19$ & $<19.6$ & $<19.3$ & & & \\
\hline S96T002196 & \multirow[t]{2}{*}{$138: 9$} & Upper $1 / 2$ & 22.6 & 24.5 & 23.55 & & & \\
\hline S96T002200 & & Lower $1 / 2$ & $<18.4$ & $<19.9$ & $<19.15$ & & & \\
\hline S96T002097 & 142: 1 & Upper $1 / 2$ & $<17.9$ & $<17.9$ & $<17.9$ & & & \\
\hline S96T002312 & \multirow[t]{2}{*}{ 142: 2} & Upper $1 / 2$ & $<20.5$ & $<18.4$ & $<19.45$ & & & \\
\hline S96T002317 & & Lower $1 / 2$ & $<18.7$ & $<19.5$ & $<19.1$ & & & \\
\hline
\end{tabular}




\begin{tabular}{|c|c|c|c|c|c|c|c|c|}
\hline Qqumula & 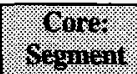 & 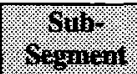 & 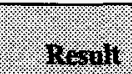 & buplicate & Whor & W\%ow & 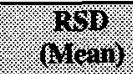 & 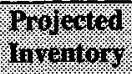 \\
\hline \multicolumn{3}{|c|}{ 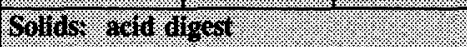 } & 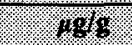 & 48 & 1968 & .018 & 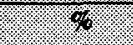 & 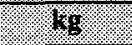 \\
\hline S96T002313 & 142: 3 & Upper $1 / 2$ & $<20.5$ & $<20.3$ & $<20.4$ & \multirow[t]{12}{*}{ Cont. } & \multirow[t]{12}{*}{ Cont. } & \multirow[t]{12}{*}{ Cont. } \\
\hline S96T002320 & & Lower $1 / 2$ & $<20.9$ & $<20.1$ & $<20.5$ & & & \\
\hline S96T002109 & \multirow[t]{2}{*}{ 142: 4} & Upper $1 / 2$ & $<20.1$ & $<20.5$ & $<20.3$ & & & \\
\hline S96T002110 & & Lower $1 / 2$ & $<19.7$ & $<19.3$ & $<19.5$ & & & \\
\hline S96T002111 & \multirow[t]{2}{*}{$142: 5$} & Upper $1 / 2$ & $<17.7$ & $<19.3$ & $<18.5$ & & & \\
\hline S96T002112 & & Lower $1 / 2$ & $<17.8$ & $<19.1$ & $<18.45$ & & & \\
\hline S96T002113 & \multirow[t]{2}{*}{ 142: 6} & Upper $1 / 2$ & $<19.5$ & $<\longdiv { 2 2 . 4 }$ & $<20.95$ & & & \\
\hline S96T002098 & & Lower $1 / 2$ & $<19.6$ & $<20.4$ & $<20$ & & & \\
\hline S96T002114 & \multirow[t]{2}{*}{ 142: 7} & Upper $1 / 2$ & $<\overline{19.8}$ & $<20.1$ & $<19.95$ & & & \\
\hline S96T002115 & & Lower $1 / 2$ & $<18.4$ & $<17.9$ & $<18.15$ & & & \\
\hline S96T002116 & \multirow[t]{2}{*}{ 142: 8} & Upper $1 / 2$ & 19.4 & 18.3 & 18.85 & & & \\
\hline S96T002117 & & Lower $1 / 2$ & $<18.8$ & $<18.5$ & $<18.65$ & & & \\
\hline \multicolumn{3}{|c|}{ 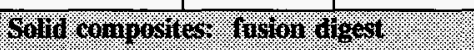 } & 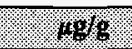 & 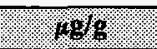 & $18 \mathrm{~g}$ & 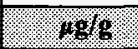 & . & 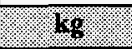 \\
\hline S96T002723 & 138 & N/A & $<1,050$ & $<1,090$ & $<1,070$ & \multirow[t]{2}{*}{$<1,050$} & \multirow[t]{2}{*}{ N/A } & \multirow[t]{2}{*}{$<2,720$} \\
\hline S96T002731 & 142 & N/A & $<1,020$ & $<1,050$ & $<1,035$ & & & \\
\hline \multicolumn{3}{|c|}{ 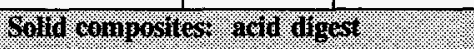 } & 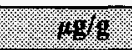 & 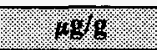 & $1.91 \mathrm{~s}$ & 10.696 & 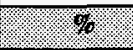 & 68 \\
\hline S96T002724 & 138 & N/A & $<34.3$ & $<34.1$ & $<34.2$ & \multirow[t]{2}{*}{$<34.2$} & \multirow[t]{2}{*}{ N/A } & \multirow[t]{2}{*}{$<88.7$} \\
\hline S96T002733 & 142 & N/A & $<33.8$ & $<31.7$ & $<32.75$ & & & \\
\hline \multicolumn{3}{|c|}{ 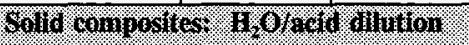 } & $.4 \%$ & $.68 / 9$ & .698 & 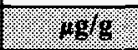 & \% & 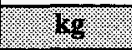 \\
\hline S96T002726I & 138 & N/A & $<28.1$ & $<27.3$ & $<27.7$ & \multirow[t]{2}{*}{$<27.0$} & \multirow[t]{2}{*}{ N/A } & \multirow[t]{2}{*}{$<70.0$} \\
\hline S96T002736I & 142 & N/A & $<27.4$ & $<25.2$ & $<26.3$ & & & \\
\hline
\end{tabular}




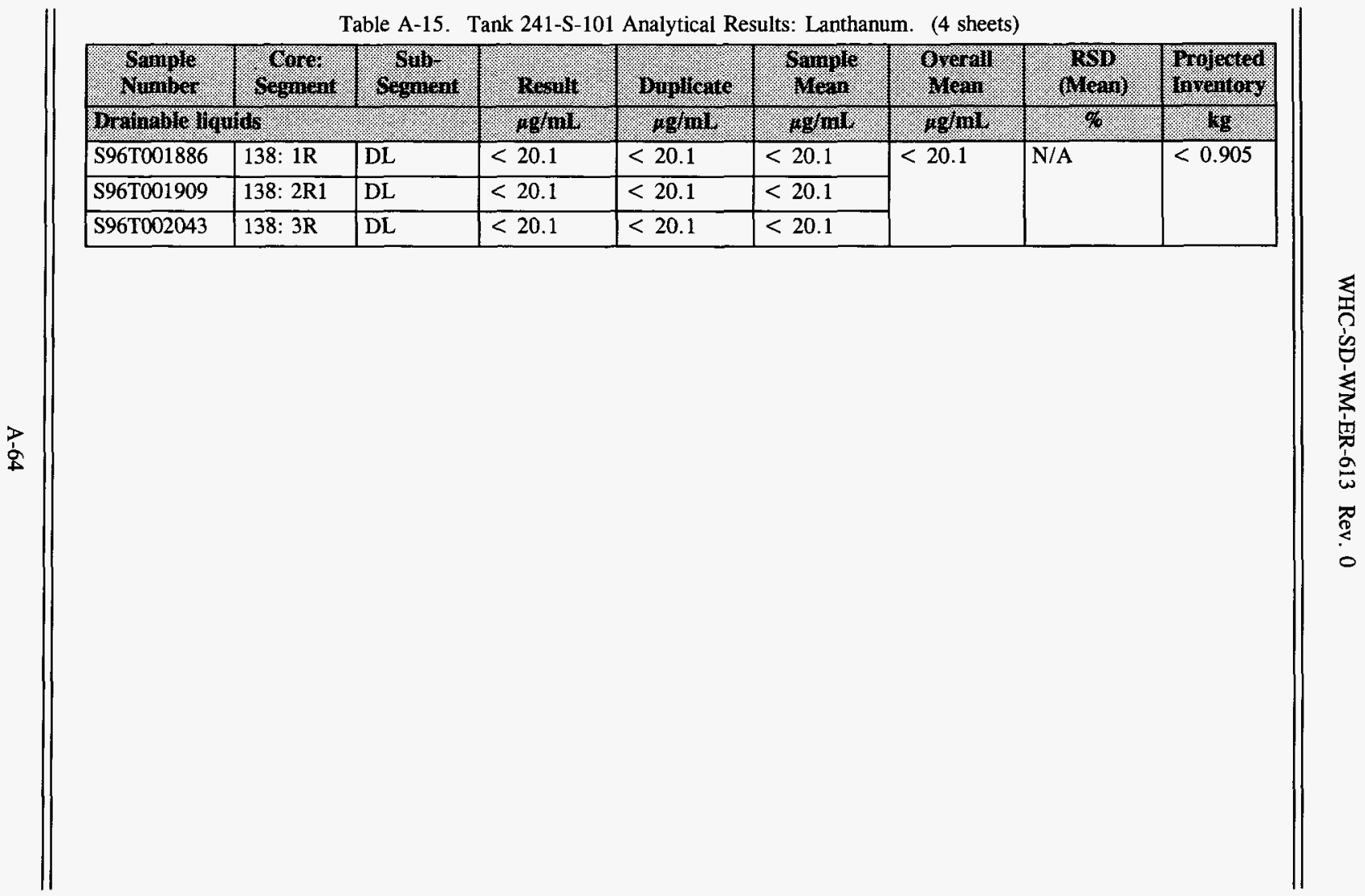




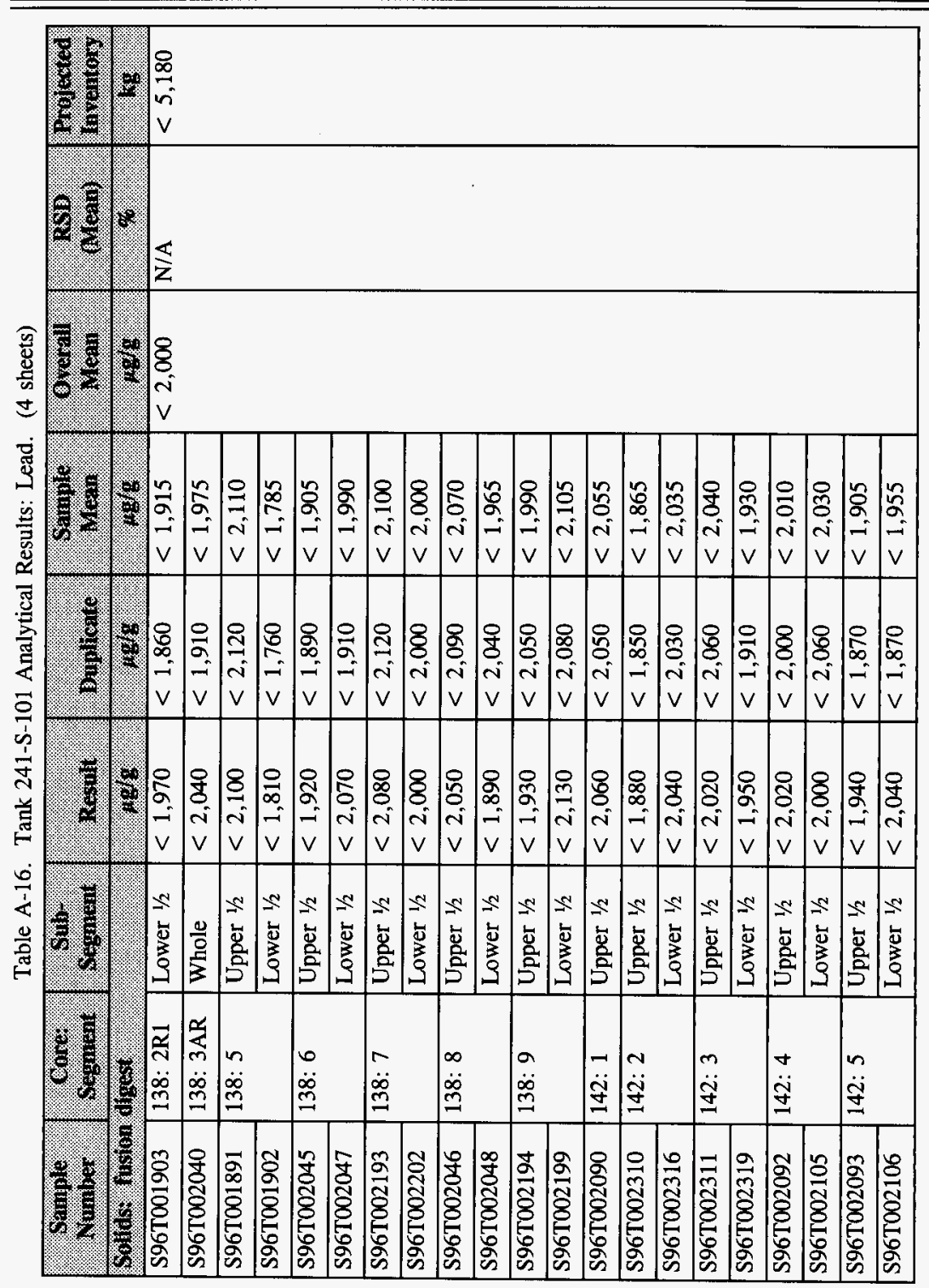




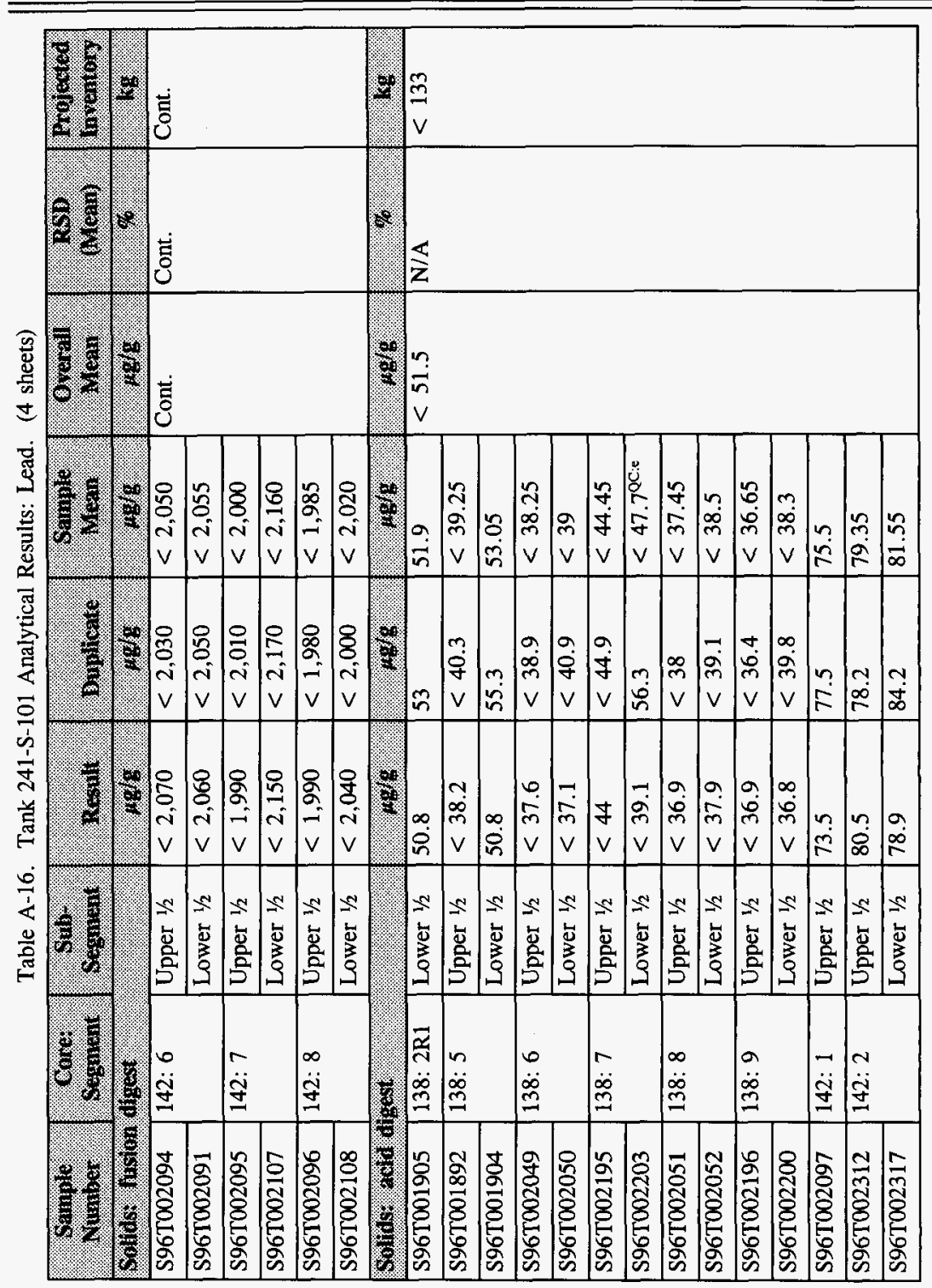


Table A-16. Tank 241-S-101 Analytical Results: Lead. (4 sheets)

\begin{tabular}{|c|c|c|c|c|c|c|c|c|}
\hline 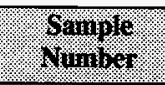 & 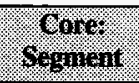 & 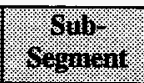 & 6osmil & Bupleate & Oo110\% & orroul & $\begin{array}{l}\text { Rop } \\
(\text { Mean) }\end{array}$ & Wurged \\
\hline \multicolumn{3}{|c|}{ 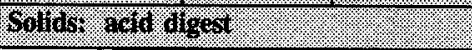 } & $\% 9$ & $.98 \mathrm{~g}=$ & 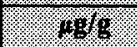 & 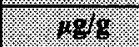 & V.\%. & 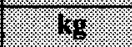 \\
\hline S96T002313 & \multirow[t]{2}{*}{ 142: 3} & Upper $1 / 2$ & $<41$ & $<40.5$ & $<40.75$ & \multirow[t]{12}{*}{ Cont. } & \multirow[t]{12}{*}{ Cont. } & \multirow[t]{12}{*}{ Cont. } \\
\hline S96T002320 & & Lower $1 / 2$ & 80.4 & 98.2 & 89.3 & & & \\
\hline S96T002109 & \multirow[t]{2}{*}{ 142: 4} & Upper $1 / 2$ & 95.4 & 88 & 91.7 & & & \\
\hline \$96T002110 & & Lower $1 / 2$ & 65.5 & 72.7 & 69.1 & & & \\
\hline S96T002111 & \multirow[t]{2}{*}{ 142: 5} & Upper $1 / 2$ & $<35.3$ & $<38.6$ & $<36.95$ & & & \\
\hline S96T002112 & & Lower $1 / 2$ & 39.6 & $<38.2$ & 38.9 & & & \\
\hline S96T002113 & \multirow[t]{2}{*}{$142: 6$} & Upper $1 / 2$ & 76.5 & 83.8 & 80.15 & & & \\
\hline S96T002098 & & Lower $1 / 2$ & $<39.3$ & $<40.8$ & $<40.05$ & & & \\
\hline S96T002114 & \multirow[t]{2}{*}{ 142: 7} & Upper $1 / 2$ & $<39.6$ & $<40.2$ & $<39.9$ & & & \\
\hline S96T002115 & & Lower $1 / 2$ & $<36.7$ & $<35.8$ & $<36.25$ & & & \\
\hline S96T002116 & \multirow[t]{2}{*}{ 142: 8} & Upper $1 / 2$ & $<37.1$ & $<36$ & $<36.55$ & & & \\
\hline S96T002117 & & Lower $1 / 2$ & $<37.5$ & $<37$ & $<37.25$ & & & \\
\hline \multicolumn{3}{|c|}{ 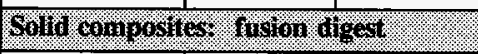 } & 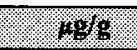 & 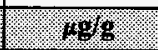 & 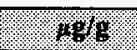 & $179 / 8$ & 28 & (kg \\
\hline S96T002723 & 138 & N/A & $<2,090$ & $<2,170$ & $<2,130$ & \multirow[t]{2}{*}{$<2,100$} & \multirow[t]{2}{*}{ N/A } & \multirow[t]{2}{*}{$<5,440$} \\
\hline \$96T002731 & 142 & N/A & $<2,040$ & $<2,100$ & $<2,070$ & & & \\
\hline \multicolumn{3}{|c|}{ 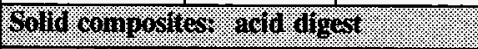 } & $.49 \%$ & .1698 & $.14 \%$ & 1.69 & $\sqrt{1.2 .6 \%}$ & (6\% \\
\hline S96T002724 & 138 & N/A & $<68.6$ & $<68.2$ & $<68.4$ & \multirow[t]{2}{*}{$<68.6$} & \multirow[t]{2}{*}{ N/A } & \multirow[t]{2}{*}{$<178$} \\
\hline S96T002733 & 142 & $\mathrm{~N} / \mathrm{A}$ & $<67.7$ & 69.9 & 68.8 & & & \\
\hline \multicolumn{3}{|c|}{ 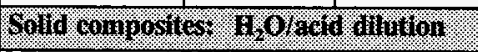 } & $1.6 \%$ & . 698 & 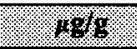 & 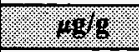 & . & 16 \\
\hline S96T002726I & 138 & N/A & $<56.2$ & $<54.6$ & $<55.4$ & \multirow[t]{2}{*}{$<54.0$} & \multirow[t]{2}{*}{ N/A } & \multirow[t]{2}{*}{$<140$} \\
\hline S96T002736I & 142 & N/A & $<54.8$ & $<50.4$ & $<52.6$ & & & \\
\hline
\end{tabular}


Table A-16. Tank 241-S-101 Analytical Results: Lead. (4 sheets)

\begin{tabular}{|c|c|c|c|c|c|c|c|c|}
\hline Momol & 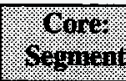 & ogmon & Mesull & Wupinge & 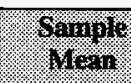 & Wholu & 49 & 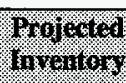 \\
\hline \multicolumn{3}{|c|}{ 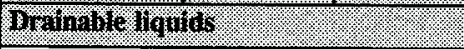 } & 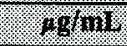 & Mglil & 69/1) & (6) & $1.6 \%$ & (1. \\
\hline S96T001886 & 138: IR & DL & $<40.1$ & $<40.1$ & $<40.1$ & \multirow[t]{3}{*}{$<40.1$} & \multirow[t]{3}{*}{ N/A } & \multirow[t]{3}{*}{$<1.80$} \\
\hline S96T001909 & 138: 2R1 & $\mathrm{DL}$ & $<40.1$ & $<40.1$ & $<40.1$ & & & \\
\hline S96T002043 & 138: $3 \mathrm{R}$ & DL & $<40.1$ & $<40.1$ & $<40.1$ & & & \\
\hline
\end{tabular}


Table A-17. Tank 241-S-101 Analytical Results: Magnesium. (4 sheets)

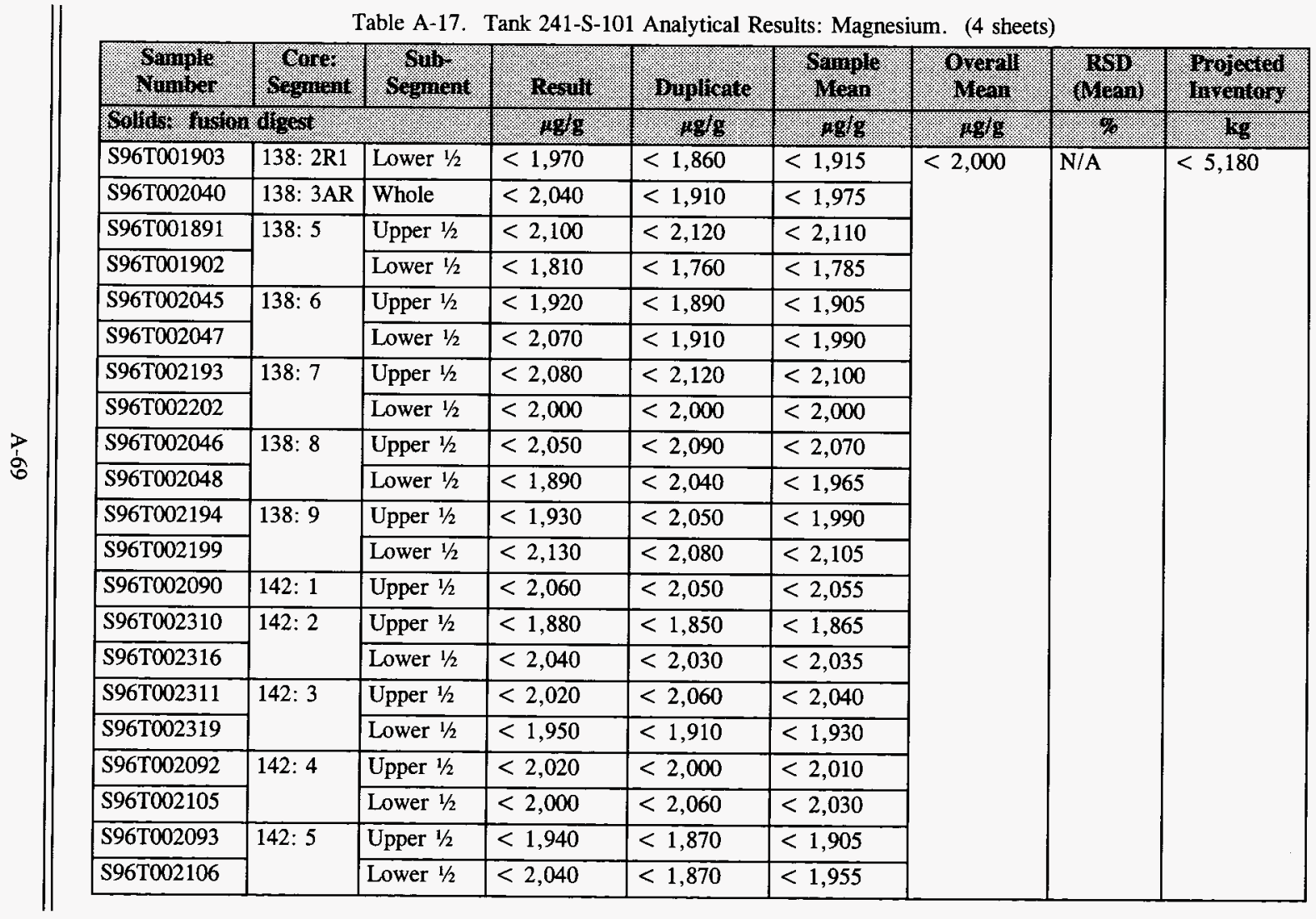


Table A-17. Tank 241-S-101 Analytical Results: Magnesium. (4 sheets)

\begin{tabular}{|c|c|c|c|c|c|c|c|c|}
\hline Walniolo & Wompin & soprent & resail & 30101\%) & Mande & Wrowl & Mror & $10 \%$ How \\
\hline \multicolumn{3}{|c|}{ 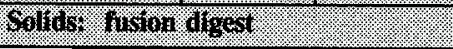 } & 1019 & $.16 m_{4}$ & 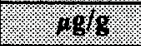 & 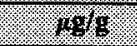 & $1 / 1 \% 1 \%$ & .160. \\
\hline S96T002094 & \multirow[t]{2}{*}{$142: 6$} & Upper $1 / 2$ & $<2,070$ & $<2,030$ & $<2,050$ & \multirow[t]{6}{*}{ Cont. } & \multirow[t]{6}{*}{ Cont. } & \multirow[t]{6}{*}{ Cont. } \\
\hline S96T002091 & & Lower $1 / 2$ & $<2,060$ & $<2,050$ & $<2,055$ & & & \\
\hline S96T002095 & \multirow[t]{2}{*}{ 142: 7} & Upper $1 / 2$ & $<1,990$ & $<2,010$ & $<2,000$ & & & \\
\hline S96T002107 & & Lower $1 / 2$ & $<2,150$ & $<2,170$ & $<2,160$ & & & \\
\hline \$96T002096 & \multirow[t]{2}{*}{$142: 8$} & Upper $1 / 2$ & $<1,990$ & $<1,980$ & $<1,985$ & & & \\
\hline S96T002108 & & Lower $1 / 2$ & $<2,040$ & $<2,000$ & $<2,020$ & & & \\
\hline \multicolumn{3}{|c|}{ Sollids, adof 6 tigest } & $.14 \mathrm{~g}$ & 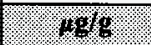 & (w) & 1018 & 8. & 148 \\
\hline S96T001905 & 138: 2R1 & Lower $1 / 2$ & $<38.1$ & $<38.7$ & $<38.4$ & \multirow[t]{14}{*}{$<42.3$} & \multirow[t]{14}{*}{ N/A } & \multirow[t]{14}{*}{$<110$} \\
\hline S96T001892 & \multirow[t]{2}{*}{$138: 5$} & Upper $1 / 2$ & $<38.2$ & $<40.3$ & $<39.25$ & & & \\
\hline S96T001904 & & Lower $1 / 2$ & $<35.8$ & $<39.2$ & $<37.5$ & & & \\
\hline S96T002049 & \multirow[t]{2}{*}{$138: 6$} & Upper $1 / 2$ & $<37.6$ & 40.7 & $<39.15$ & & & \\
\hline S96T002050 & & Lower $1 / 2$ & 46 & 73.9 & $59.95^{\mathrm{QC}: \mathrm{e}}$ & & & \\
\hline S96T002195 & \multirow[t]{2}{*}{ 138: 7} & Upper $1 / 2$ & $<44$ & $<44.9$ & $<44.45$ & & & \\
\hline S96T002203 & & Lower $1 / 2$ & $<39.1$ & $<40.8$ & $<39.95$ & & & \\
\hline S96T002051 & \multirow[t]{2}{*}{ 138: 8} & Upper $1 / 2$ & 52.9 & 54.8 & 53.85 & & & \\
\hline S96T002052 & & Lower $1 / 2$ & $<37.9$ & $<39.1$ & $<38.5$ & & & \\
\hline S96T002196 & \multirow[t]{2}{*}{$138: 9$} & Upper $1 / 2$ & $<36.9$ & $<36.4$ & $<36.65$ & & & \\
\hline S96T002200 & & Lower $1 / 2$ & $<36.8$ & $<39.8$ & $<38.3$ & & & \\
\hline S96T002097 & 142: 1 & Upper $1 / 2$ & $<35.7$ & $<35.7$ & $<35.7$ & & & \\
\hline S96T002312 & \multirow[t]{2}{*}{ 142: 2} & Upper $1 / 2$ & $<40.9$ & $<36.8$ & $<38.85$ & & & \\
\hline S96T002317 & & Lower $1 / 2$ & $<37.3$ & $<39.1$ & $<38.2$ & & & \\
\hline
\end{tabular}


Table A-17. Tank 241-S-101 Analytical Results: Magnesium. (4 sheets)

\begin{tabular}{|c|c|c|c|c|c|c|c|c|}
\hline $\begin{array}{l}\text { Goming } \\
\text { Homper }\end{array}$ & ofonent & Semont & Reriul & Bingllore & Gamigl & Worill & 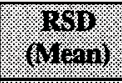 & $\begin{array}{l}\text { Proigated } \\
\text { mincitory }\end{array}$ \\
\hline \multicolumn{3}{|c|}{ 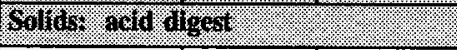 } & . & 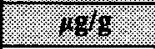 & 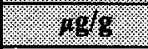 & 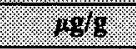 & $6 \%$ & 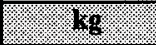 \\
\hline S96T002313 & \multirow[t]{2}{*}{$142: 3$} & Upper $1 / 2$ & $<41$ & $<40.5$ & $<40.75$ & \multirow[t]{12}{*}{ Cont. } & \multirow[t]{12}{*}{ Cont. } & \multirow[t]{12}{*}{ Cont. } \\
\hline S96T002320 & & Lower $1 / 2$ & $<41.7$ & $<40.1$ & $<40.9$ & & & \\
\hline S96T002109 & \multirow[t]{2}{*}{$142: 4$} & Upper $1 / 2$ & $<40.1$ & $<40.9$ & $<40.5$ & & & \\
\hline S96T002110 & & Lower $1 / 2$ & 61.7 & 72.1 & 66.9 & & & \\
\hline S96T002111 & \multirow[t]{2}{*}{ 142: 5} & Upper $1 / 2$ & $<35.3$ & $<38.6$ & $<36.95$ & & & \\
\hline S96T002112 & & Lower $1 / 2$ & $<35.7$ & 41.7 & $<38.7$ & & & \\
\hline S96T002113 & \multirow[t]{2}{*}{$142: 6$} & Upper $1 / 2$ & $<38.9$ & $<44.8$ & $<41.85$ & & & \\
\hline S96T002098 & & Lower $1 / 2$ & $<39.3$ & 72.1 & $<55.7^{\mathrm{QC}: \mathrm{e}}$ & & & \\
\hline S96T002114 & \multirow[t]{2}{*}{$142: 7$} & Upper $1 / 2$ & 51.9 & 43.6 & 47.75 & & & \\
\hline S96T002115 & & Lower $1 / 2$ & $<36.7$ & $<35.8$ & $<36.25$ & & & \\
\hline S96T002116 & \multirow[t]{2}{*}{$142: 8$} & Upper $1 / 2$ & $<37.1$ & $<36$ & $<36.55$ & & & \\
\hline S96T002117 & & Lower $1 / 2$ & $<37.5$ & $<37$ & $<37.25$ & & & \\
\hline \multicolumn{3}{|c|}{ 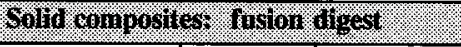 } & 1896 & 1.96 & $.48 \%$ & 1088 & $\%$ & 48 \\
\hline S96T002723 & 138 & N/A & $<2,090$ & $<2,170$ & $<2,130$ & \multirow[t]{2}{*}{$<2,100$} & \multirow[t]{2}{*}{$\mathrm{N} / \mathrm{A}$} & \multirow[t]{2}{*}{$<5,440$} \\
\hline S96T002731 & 142 & N/A & $<2,040$ & $<2,100$ & $<2,070$ & & & \\
\hline \multicolumn{3}{|c|}{ 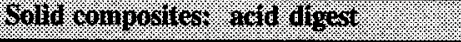 } & .1819 & 96 & 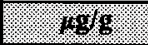 & 9.98 & $8 \%$ & 63 \\
\hline S96T002724 & 138 & N/A & $<68.6$ & $<68.2$ & $<68.4$ & \multirow[t]{2}{*}{$<67.0$} & \multirow[t]{2}{*}{ N/A } & \multirow[t]{2}{*}{$<174$} \\
\hline S96T002733 & 142 & $\mathrm{~N} / \mathrm{A}$ & $<67.7$ & $<63.5$ & $<65.6$ & & & \\
\hline \multicolumn{3}{|c|}{ 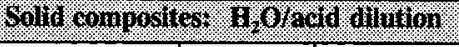 } & 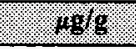 & 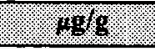 & 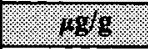 & 1.689 & $1.8 \%$ & .18 \\
\hline S96T002726I & 138 & N/A & $<56.2$ & $<54.6$ & $<55.4$ & \multirow[t]{2}{*}{$<54.0$} & \multirow[t]{2}{*}{ N/A } & \multirow[t]{2}{*}{$<140$} \\
\hline S96T002736I & 142 & $\mathrm{~N} / \mathrm{A}$ & $<54.8$ & $<50.4$ & $<52.6$ & & & \\
\hline
\end{tabular}


Table A-17. Tank 241-S-101 Analytical Results: Magnesium. (4 sheets)

\begin{tabular}{|c|c|c|c|c|c|c|c|c|}
\hline Sample & $\begin{array}{l}\text { Cone? } \\
\text { Segrnent }\end{array}$ & $\begin{array}{l}\text { Sult } \\
\text { Seprnant }\end{array}$ & Result & Miplicate & $\begin{array}{l}\text { Sample } \\
\text { Vreani }\end{array}$ & $\begin{array}{l}\text { Orgaran } \\
\text { Vean }\end{array}$ & Tero & $\begin{array}{l}\text { Mroidered } \\
\text { linrentor }\end{array}$ \\
\hline \multicolumn{2}{|c|}{ Granable liquís : } & (1.). & (hining & 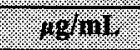 & Ig/nil. & Ifgin: & 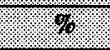 & 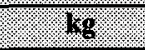 \\
\hline S96T001886 & 138: $1 \mathrm{R}$ & $\mathrm{DL}$ & $<40.1$ & $<40.1$ & $<40.1$ & \multirow[t]{3}{*}{$<40.1$} & \multirow[t]{3}{*}{$\mathrm{N} / \mathrm{A}$} & \multirow[t]{3}{*}{$<1.80$} \\
\hline S96T001909 & 138: 2R1 & $\overline{\mathrm{DL}}$ & $<40.1$ & $<40.1$ & $<40.1$ & & & \\
\hline S96T002043 & 138: 3R & $\overline{\mathrm{DL}}$ & $<40.1$ & $<40.1$ & $<40.1$ & & & \\
\hline
\end{tabular}


WHC-SD-WM-ER-613 Rev. 0

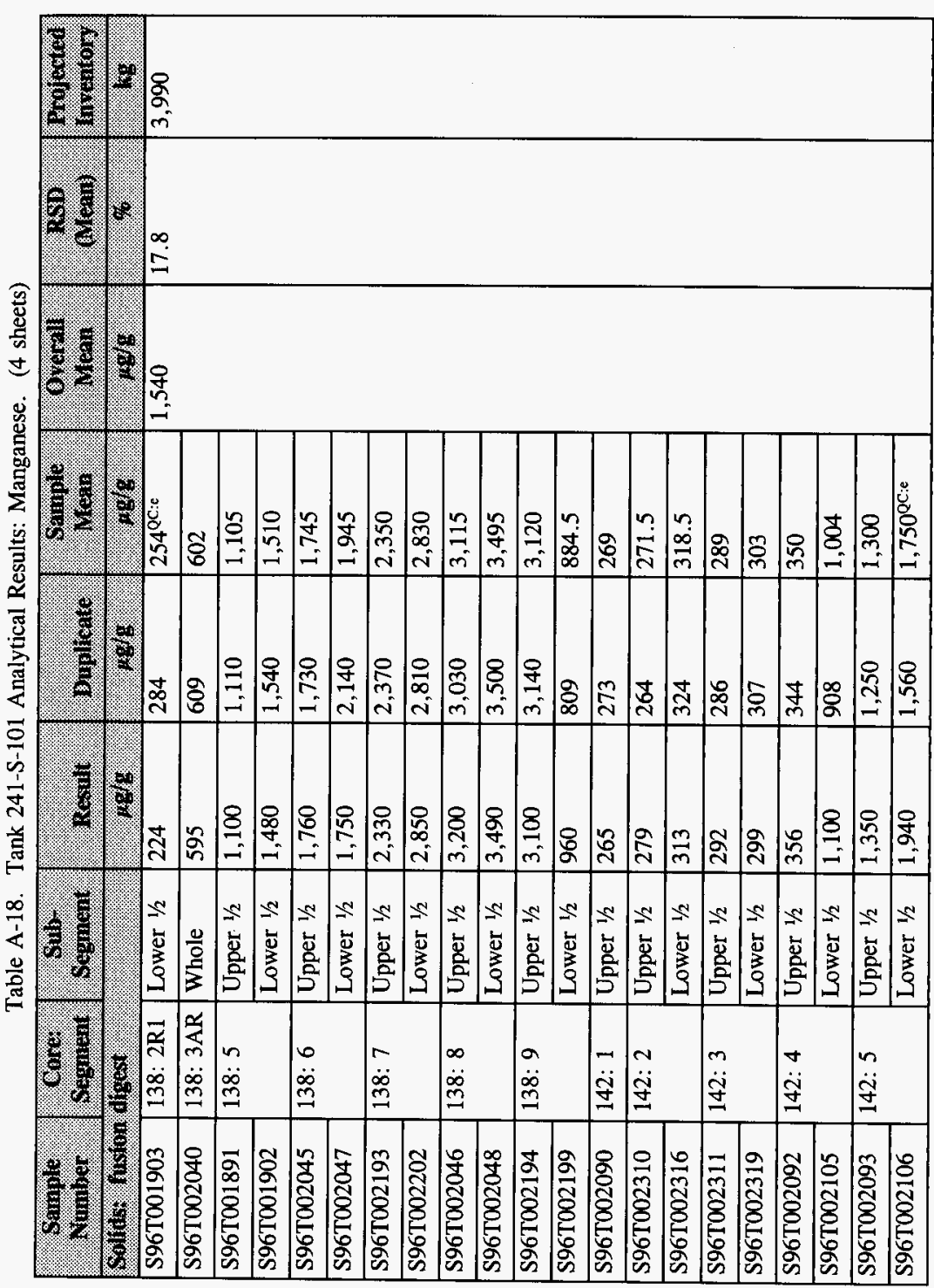


Table A-18. Tank 241-S-101 Analytical Results: Manganese. (4 sheets)

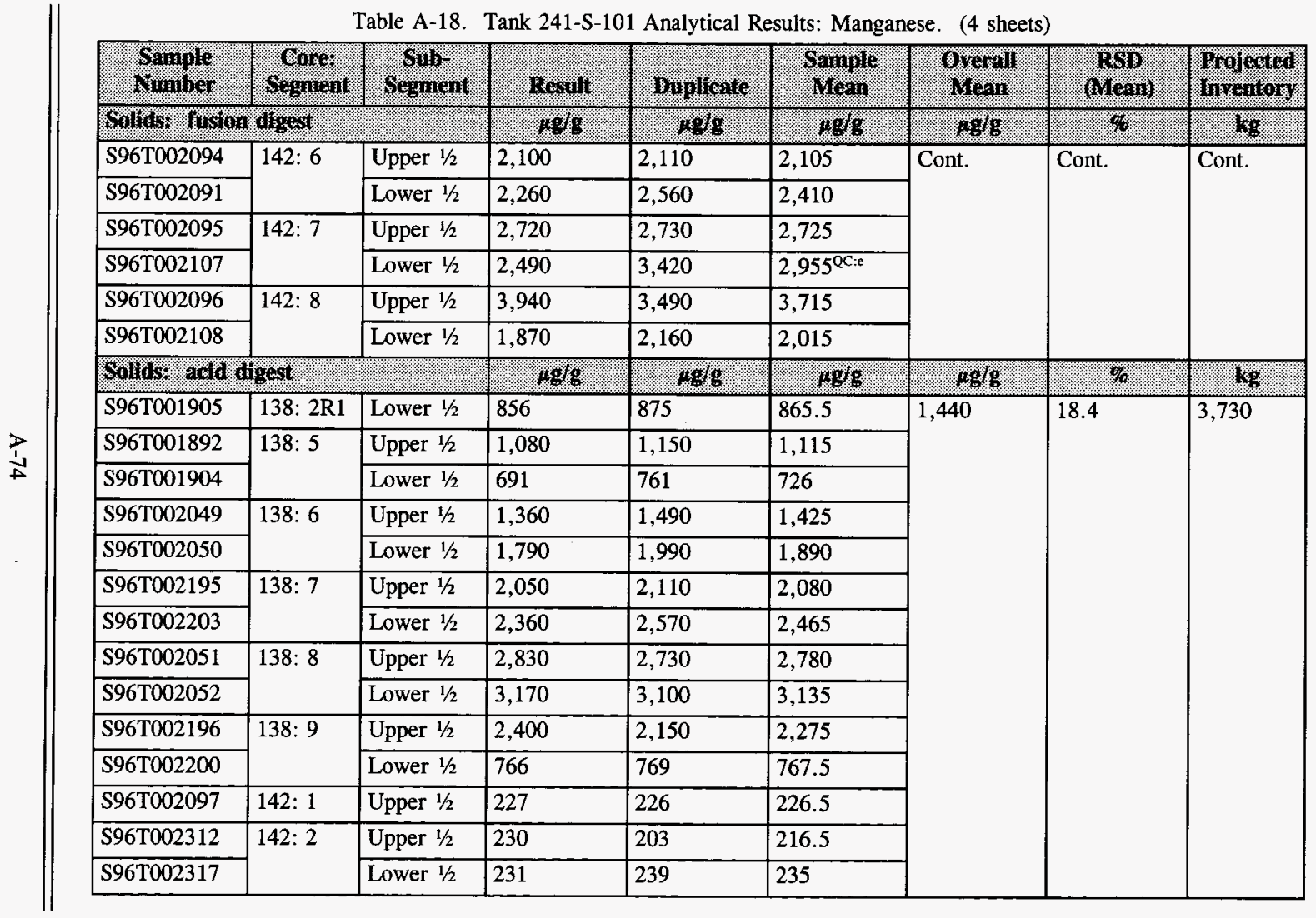


Table A-18. Tank 241-S-101 Analytical Results: Manganese. (4 sheets)

\begin{tabular}{|c|c|c|c|c|c|c|c|c|}
\hline Marmole & 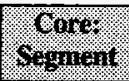 & Sogment & ireriall & Buplicate & Gomple & \% $14 \%$ & (4oan) & Wouprod \\
\hline \multicolumn{3}{|c|}{ 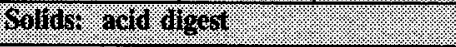 } & 1896 & $4 \%$ & m $/ 1 \mathrm{~g}$ & 1946 & W. & $1.18 \mathrm{~b}$. \\
\hline S96T002313 & \multirow[t]{2}{*}{$142: 3$} & Upper $1 / 2$ & 1,800 & 1,560 & 1,680 & \multirow[t]{12}{*}{ Cont. } & \multirow[t]{12}{*}{ Cont. } & \multirow[t]{12}{*}{ Cont. } \\
\hline S96T002320 & & Lower $1 / 2$ & 248 & 251 & 249.5 & & & \\
\hline S96T002109 & \multirow[t]{2}{*}{ 142: 4} & Upper $1 / 2$ & 286 & 286 & 286 & & & \\
\hline S96T002110 & & Lower $1 / 2$ & 788 & 802 & 795 & & & \\
\hline S96T002111 & \multirow[t]{2}{*}{ 142: 5} & Upper $1 / 2$ & 710 & 1,000 & $855^{\mathrm{QC}: \mathrm{e}}$ & & & \\
\hline S96T002112 & & Lower $1 / 2$ & 1,360 & 1,430 & 1,395 & & & \\
\hline S96T002113 & \multirow[t]{2}{*}{ 142: 6} & Upper $1 / 2$ & 220 & 257 & 238.5 & & & \\
\hline S96T002098 & & Lower $1 / 2$ & 1,960 & 3,190 & $2,575^{\mathrm{QC}: \mathrm{e}}$ & & & \\
\hline S96T002114 & \multirow[t]{2}{*}{$142: 7$} & Upper $1 / 2$ & 2,210 & 2,220 & 2,215 & & & \\
\hline S96T002115 & & Lower $1 / 2$ & 2,960 & 2,900 & 2,930 & & & \\
\hline S96T002116 & \multirow[t]{2}{*}{$142: 8$} & Upper $1 / 2$ & 3,230 & 3,130 & 3,180 & & & \\
\hline S96T002117 & & Lower $1 / 2$ & 1,620 & 1,260 & $1,440^{\text {QC:c }}$ & & & \\
\hline \multicolumn{3}{|c|}{ 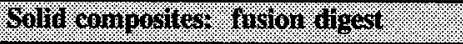 } & 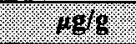 & 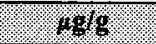 & $10 \%$ & 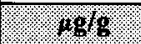 & (2.8. & . \\
\hline S96T002723 & 138 & N/A & 2,050 & 2,020 & 2,035 & \multirow[t]{2}{*}{1,700} & \multirow[t]{2}{*}{19.7} & \multirow[t]{2}{*}{4,410} \\
\hline S96T002731 & 142 & N/A & 1,340 & 1,390 & 1,365 & & & \\
\hline \multicolumn{3}{|c|}{ Solld gonposilest adul digest } & 48 & $.18 \mathrm{~g}$ & 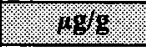 & $.78 \%$ & $\%$ & (kg \\
\hline S96T002724 & 138 & N/A & 1,960 & 1,870 & 1,915 & \multirow[t]{2}{*}{1,580} & \multirow[t]{2}{*}{21.0} & \multirow[t]{2}{*}{4,100} \\
\hline S96T002733 & 142 & N/A & 1,310 & 1,190 & 1,250 & & & \\
\hline \multicolumn{3}{|c|}{ 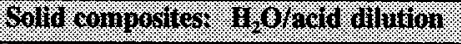 } & 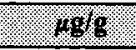 & 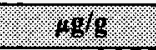 & 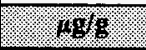 & 4.98 & \%. & (16\% \\
\hline S96T002726 & 138 & $\mathrm{~N} / \mathrm{A}$ & $<5.62$ & $<5.46$ & $<5.54$ & \multirow[t]{2}{*}{$<5.4$} & \multirow[t]{2}{*}{ N/A } & \multirow[t]{2}{*}{$<14.0$} \\
\hline S96T002736 & 142 & N/A & $<5.48$ & $<5.04$ & $<5.26$ & & & \\
\hline
\end{tabular}


Table A-18. Tank 241-S-101 Analytical Results: Manganese. (4 sheets)

\begin{tabular}{|c|c|c|c|c|c|c|c|c|}
\hline Whande & 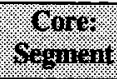 & Scalli, & Result & Buplicate & Sample & 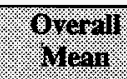 & $\begin{array}{l}(140 \\
(10+10)\end{array}$ & 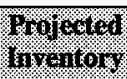 \\
\hline \multicolumn{3}{|c|}{ 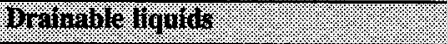 } & (201nir & 4101. & 40 & 18111 & \%) & 68 \\
\hline S96T001886 & 138: $1 \mathrm{R}$ & DL & $<4.01$ & $<4.01$ & $<4.01$ & \multirow[t]{3}{*}{$<4.01$} & \multirow[t]{3}{*}{ N/A } & \multirow[t]{3}{*}{$<0.180$} \\
\hline \$96T001909 & 138: 2R1 & DL & $<4.01$ & $<4.01$ & $<4.01$ & & & \\
\hline S96T002043 & 138: 3R & DL & $<4.01$ & $<4.01$ & $<4.01$ & & & \\
\hline
\end{tabular}


Table A-19. Tank 241-S-101 Analytical Results: Molybdenum. (4 sheets)

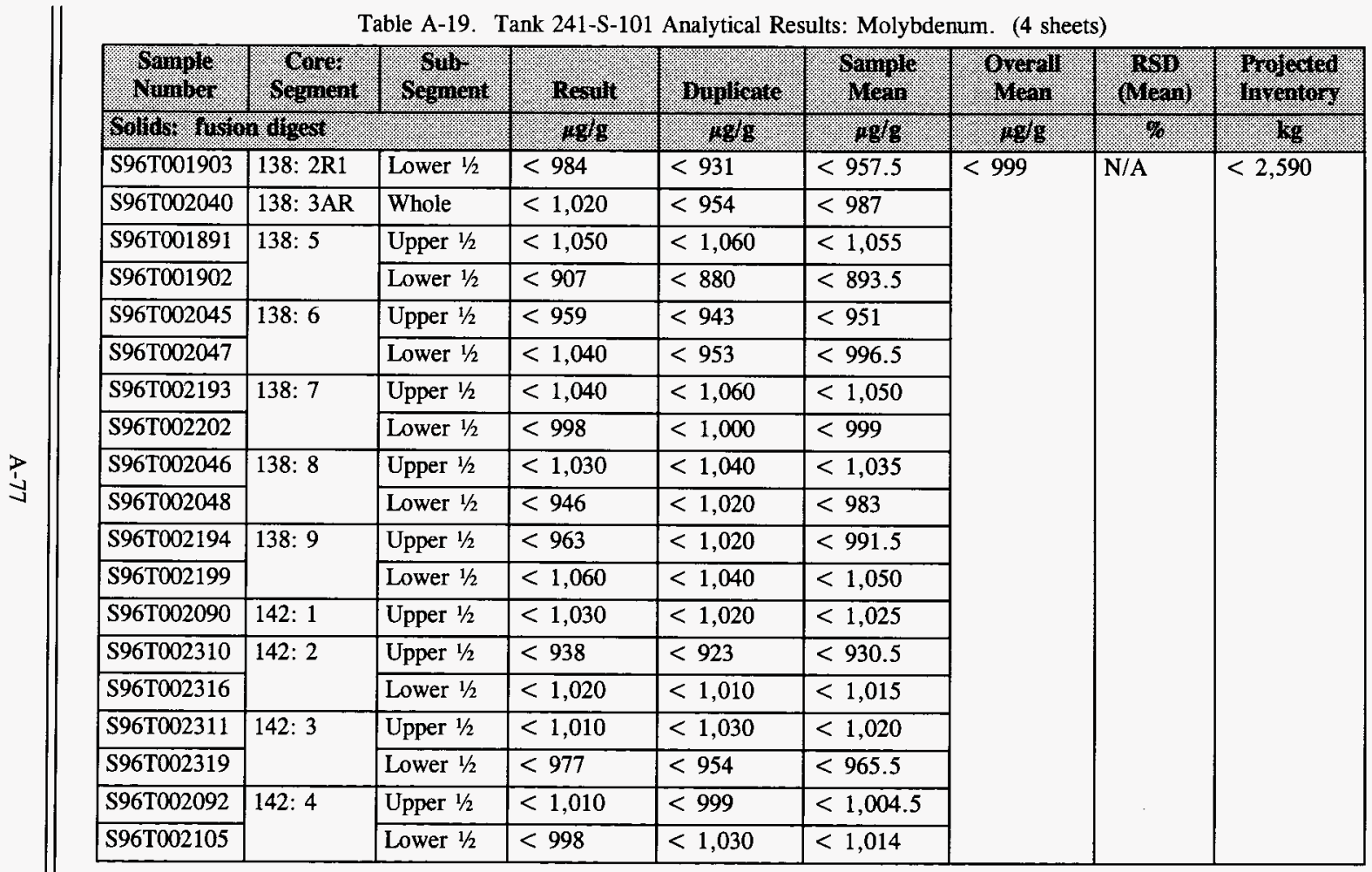


Table A-19. Tank 241-S-101 Analytical Results: Molybdenum. (4 sheets)

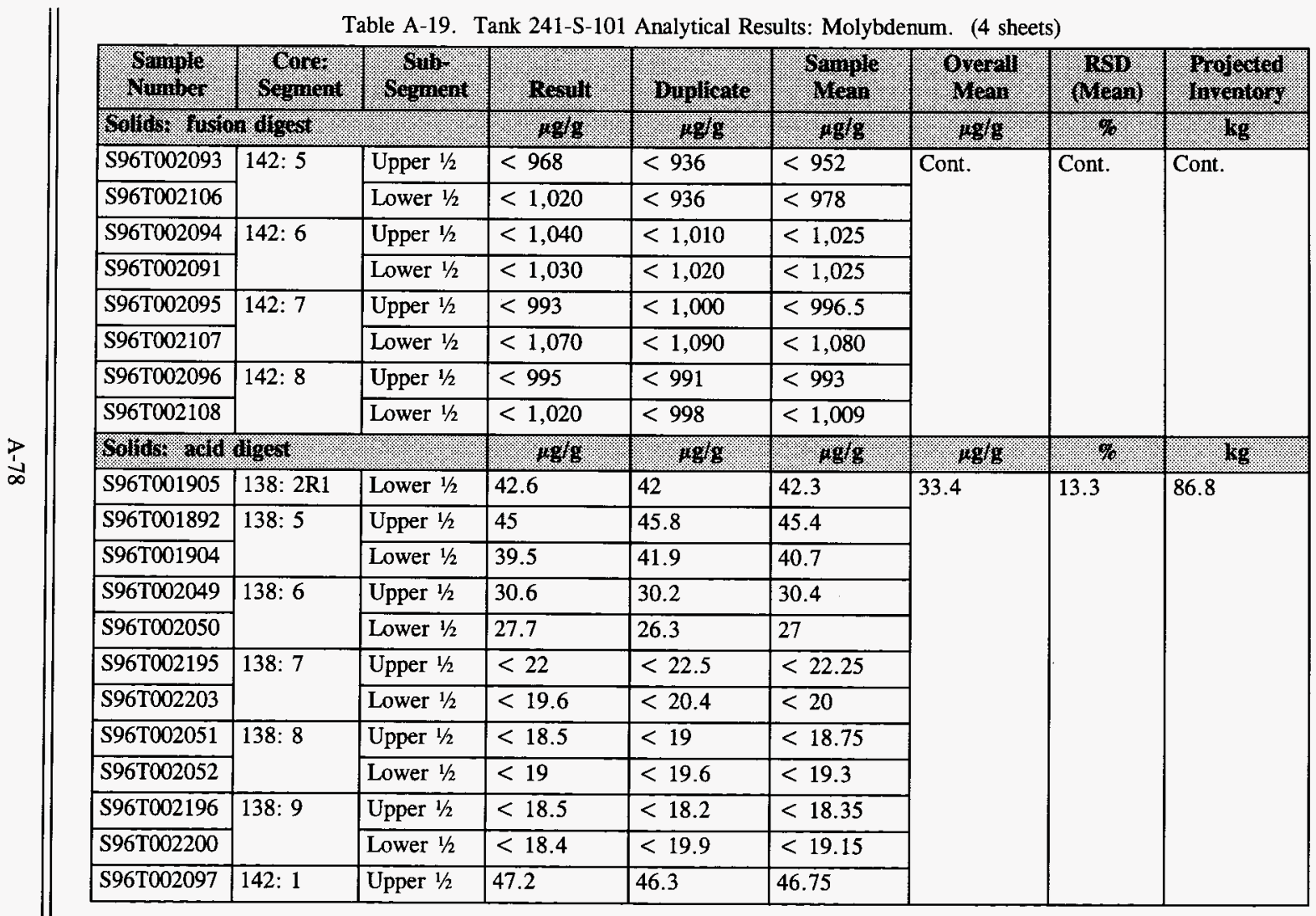


Table A-19. Tank 241-S-101 Analytical Results: Molybdenum. (4 sheets)

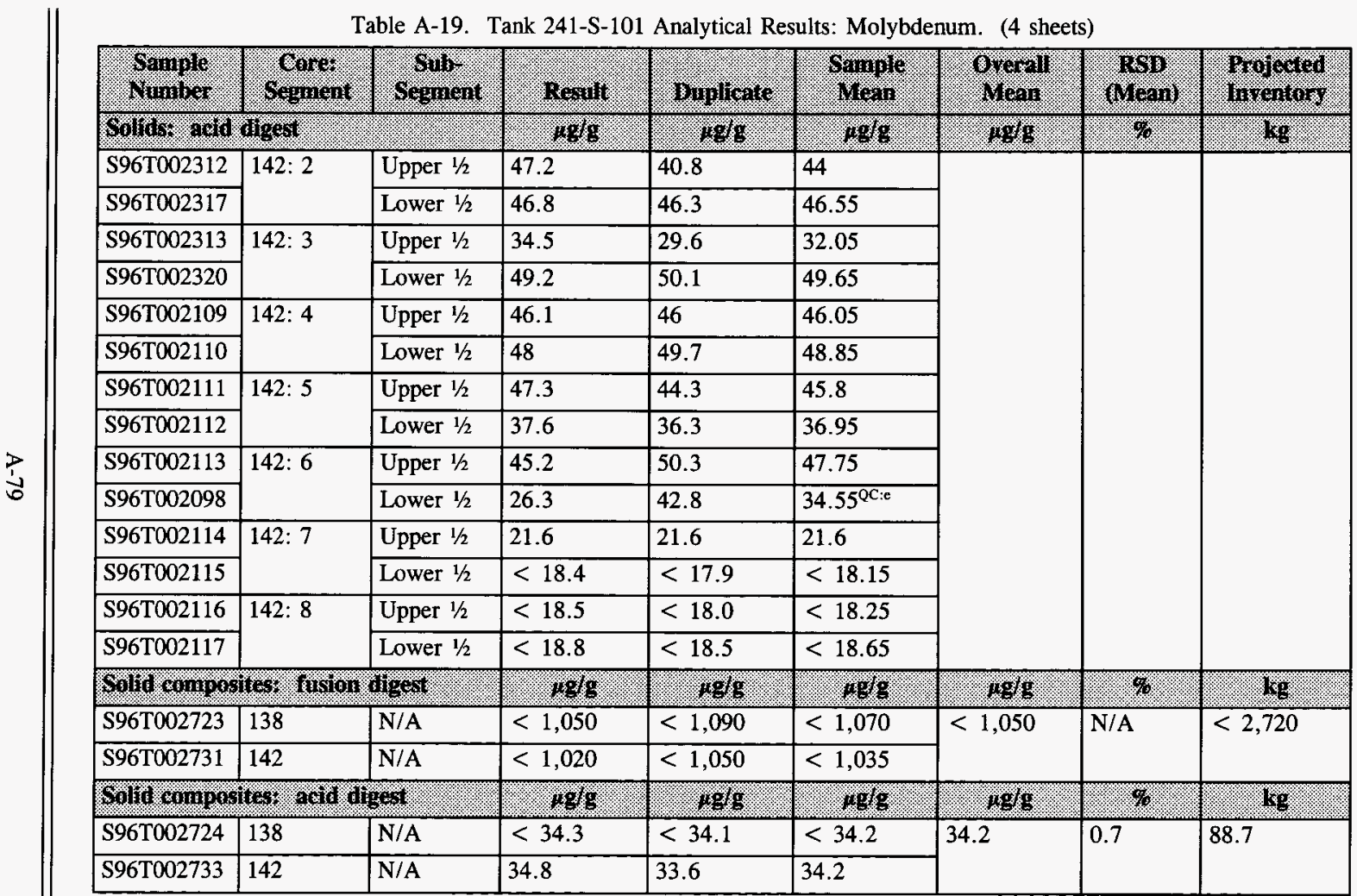


Table A-19. Tank 241-S-101 Analytical Results: Molybdenum. (4 sheets)

\begin{tabular}{|c|c|c|c|c|c|c|c|c|}
\hline Whamol & 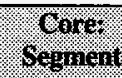 & (8) & Rerill & Bilniloate & onimo & Whan & $\begin{array}{l}\cos 18 \\
\mathrm{Hen}\end{array}$ & Horrager \\
\hline \multicolumn{3}{|c|}{ 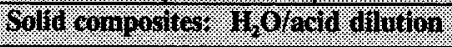 } & 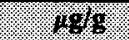 & 148 & 80 & 1008 & $\%$ & 68 \\
\hline S96T002726 & 138 & N/A & $<28.1$ & $<27.3$ & $<27.7$ & \multirow[t]{2}{*}{$<28.9$} & \multirow[t]{2}{*}{ N/A } & \multirow[t]{2}{*}{74.9} \\
\hline S96T002736 & 142 & N/A & 34.8 & $<25.2$ & $30^{\mathrm{QC}: e}$ & & & \\
\hline \multicolumn{3}{|c|}{ Grinable loquids } & $98 / 11$ & $10 / 4181$. & 014611 & H110 & $6 \%$ & 16: \\
\hline S96T001886 & 138: 1R & DL & 86.7 & 87.2 & 86.95 & \multirow[t]{3}{*}{84.6} & \multirow[t]{3}{*}{3.2} & \multirow[t]{3}{*}{3.81} \\
\hline S96T001909 & 138: 2R1 & DL & 86.5 & 88.8 & 87.65 & & & \\
\hline S96T002043 & 138: 3R & DL & 79.6 & 78.9 & 79.25 & & & \\
\hline
\end{tabular}




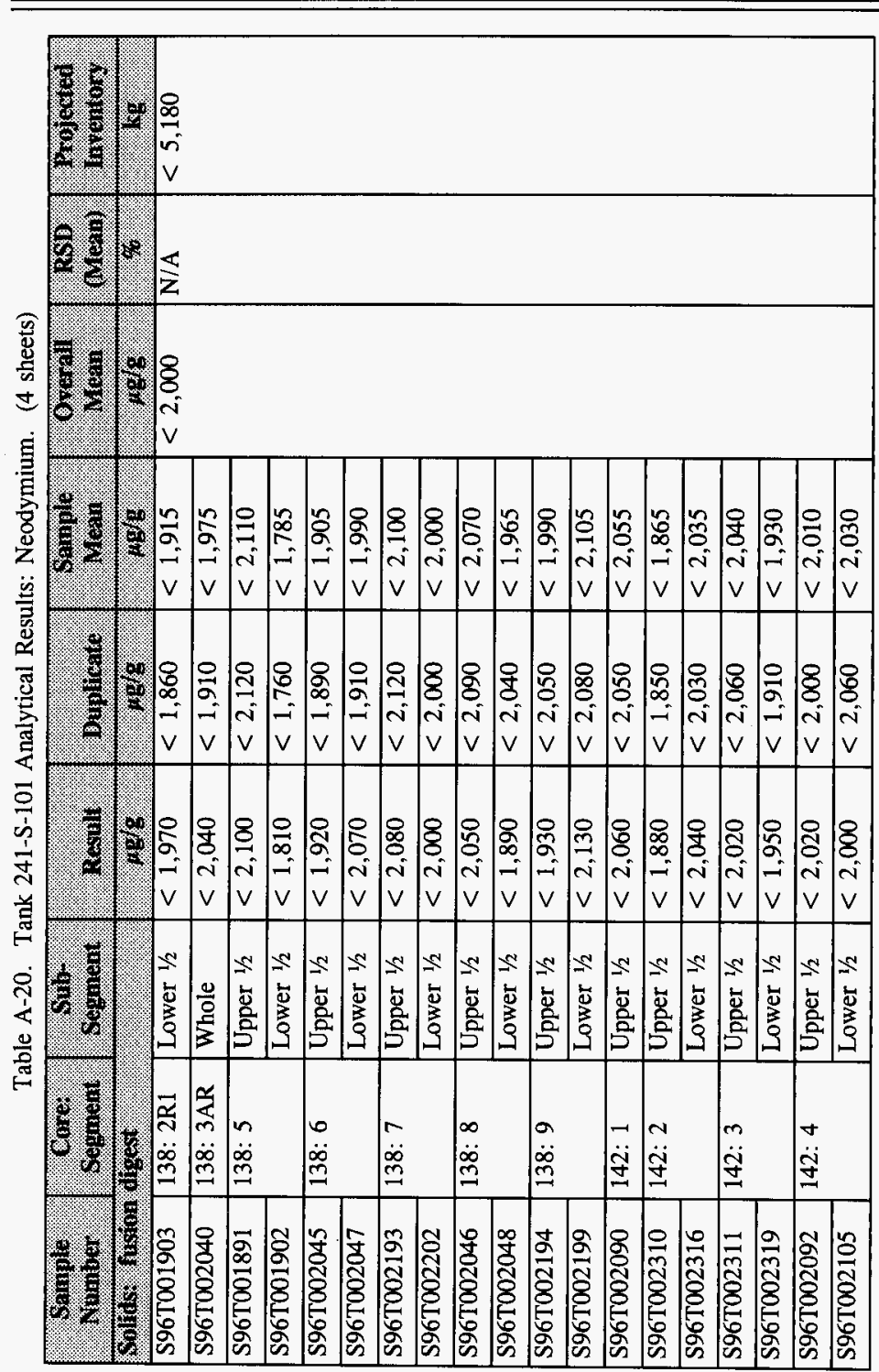


WHC-SD-WM-ER-613 Rev. 0

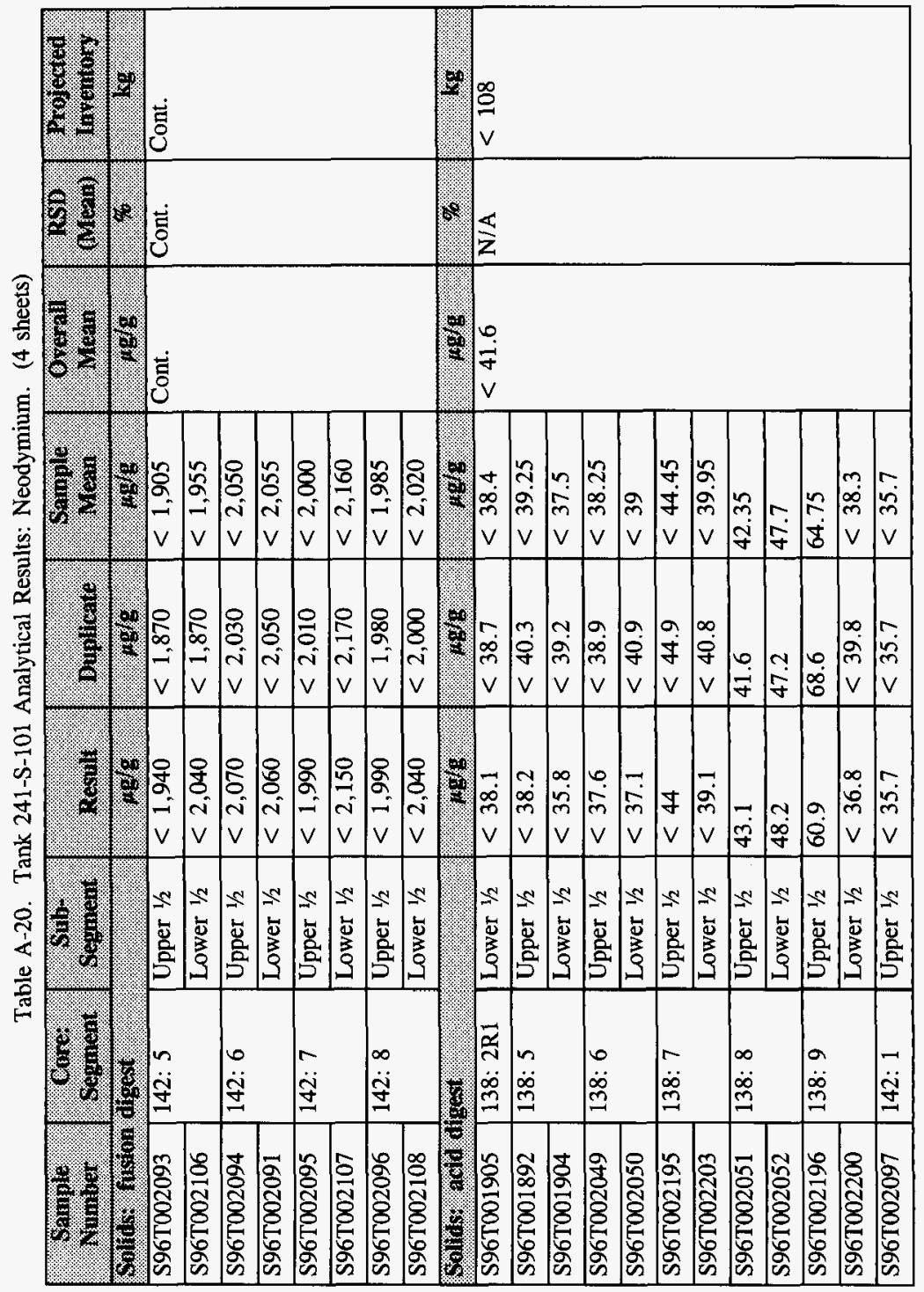


Table A-20. Tank 241-S-101 Analytical Results: Neodymium. (4 sheets)

\begin{tabular}{|c|c|c|c|c|c|c|c|c|}
\hline Whanlo & 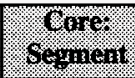 & 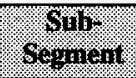 & revilit. & Buplatio & Wapro & Oresil & Won & Hrofector \\
\hline S96T002312 & \multirow[t]{2}{*}{$142: 2$} & Upper $1 / 2$ & $<40.9$ & $<36.8$ & $<38.85$ & \multirow[t]{10}{*}{ Cont. } & \multirow[t]{10}{*}{ Cont. } & \multirow[t]{10}{*}{ Cont. } \\
\hline S96T002317 & & Lower $1 / 2$ & $<37.3$ & $<39.1$ & $<38.2$ & & & \\
\hline S96T002313 & $142: 3$ & Upper $1 / 2$ & $<41$ & $<40.5$ & $<40.75$ & & & \\
\hline S96T002109 & \multirow[t]{2}{*}{ 142: 4} & Upper $1 / 2$ & $<40.1$ & $<40.9$ & $<40.5$ & & & \\
\hline S96T002110 & & Lower $1 / 2$ & $<39.3$ & $<38.6$ & $<38.95$ & & & \\
\hline S96T002111 & \multirow[t]{2}{*}{$142: 5$} & Upper $1 / 2$ & $<35.3$ & $<38.6$ & $<36.95$ & & & \\
\hline S96T002112 & & Lower $1 / 2$ & $<35.7$ & $<38.2$ & $<36.95$ & & & \\
\hline S96T002115 & $142: 7$ & Lower $1 / 2$ & 44.6 & 43.9 & 44.25 & & & \\
\hline S96T002116 & \multirow[t]{2}{*}{ 142: 8} & Upper $1 / 2$ & 52 & 50.4 & 51.2 & & & \\
\hline S96T002117 & & Lower $1 / 2$ & 45.5 & $<37$ & $<41.25$ & & & \\
\hline \multicolumn{3}{|c|}{ 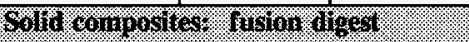 } & wogs & 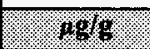 & 149 & . & $\%$ & W \\
\hline S96T002723 & 138 & N/A & $<2,090$ & $<2,170$ & $<2,130$ & \multirow[t]{2}{*}{$<2,100$} & \multirow[t]{2}{*}{ N/A } & \multirow[t]{2}{*}{$<5,440$} \\
\hline S96T002731 & 142 & N/A & $<2,040$ & $<2,100$ & $<\overline{2}, \overline{070}$ & & & \\
\hline \multicolumn{3}{|c|}{ 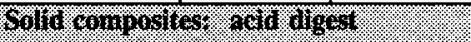 } & 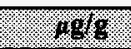 & 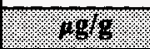 & 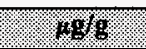 & 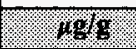 & 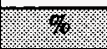 & (1) \\
\hline S96T002724 & 138 & N/A & $<68.6$ & $<68.2$ & $<68.4$ & \multirow[t]{2}{*}{$<67.0$} & \multirow[t]{2}{*}{ N/A } & \multirow[t]{2}{*}{$<174$} \\
\hline S96T002733 & 142 & N/A & $<67.7$ & $<63.5$ & $<65.6$ & & & \\
\hline
\end{tabular}


Table A-20. Tank 241-S-101 Analytical Results: Neodymium. (4 sheets)

\begin{tabular}{|c|c|c|c|c|c|c|c|c|}
\hline $\begin{array}{l}\text { Sample: } \\
\text { Nomber. }\end{array}$ & $\begin{array}{l}\text { Core: } \\
\text { Segmenis }\end{array}$ & $\begin{array}{l}\text { Subt: } \\
\text { Segment }\end{array}$ & Rerill & Duplicate & $\begin{array}{l}\text { Seringle } \\
\text { Nean }\end{array}$ & $\begin{array}{l}\text { Overal } \\
\text { Nean }\end{array}$ & Mesia & $\begin{array}{l}\text { Trojected } \\
\text { Imentory }\end{array}$ \\
\hline \multicolumn{3}{|c|}{ 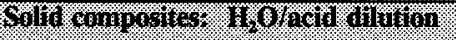 } & Ifgg & $19 \mathrm{~g} / \mathrm{g}$ & 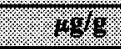 & $.18 \mathrm{gg}$ & 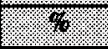 & (3g \\
\hline S96T002726 & 138 & N/A & $<56.2$ & $<54.6$ & $<55.4$ & \multirow[t]{2}{*}{$<54.0$} & \multirow[t]{2}{*}{ N/A } & \multirow[t]{2}{*}{$<140$} \\
\hline S96T002736 & $\overline{142}$ & N/A & $<54.8$ & $<50.4$ & $<52.6$ & & & \\
\hline \multicolumn{3}{|c|}{ Grainable liquids } & Ig g/mi & Hefint: & $139 \mathrm{~min}$ & $\pi 8 / \mathrm{ml}$ & \%. & lig \\
\hline S96T001886 & 138: 1R & DL & $<40.1$ & $<40.1$ & $<40.1$ & \multirow[t]{3}{*}{$<40.1$} & \multirow[t]{3}{*}{ N/A } & \multirow[t]{3}{*}{$<1.80$} \\
\hline S96T001909 & 138: $2 \mathrm{R} 1$ & $\overline{\mathrm{DL}}$ & $<40.1$ & $<40.1$ & $<40.1$ & & & \\
\hline S96T002043 & $138: 3 R$ & $\overline{\mathrm{DL}}$ & $<40.1$ & $<40.1$ & $<40.1$ & & & \\
\hline
\end{tabular}


Table A-21. Tank 241-S-101 Analytical Results: Nickel. (4 sheets)

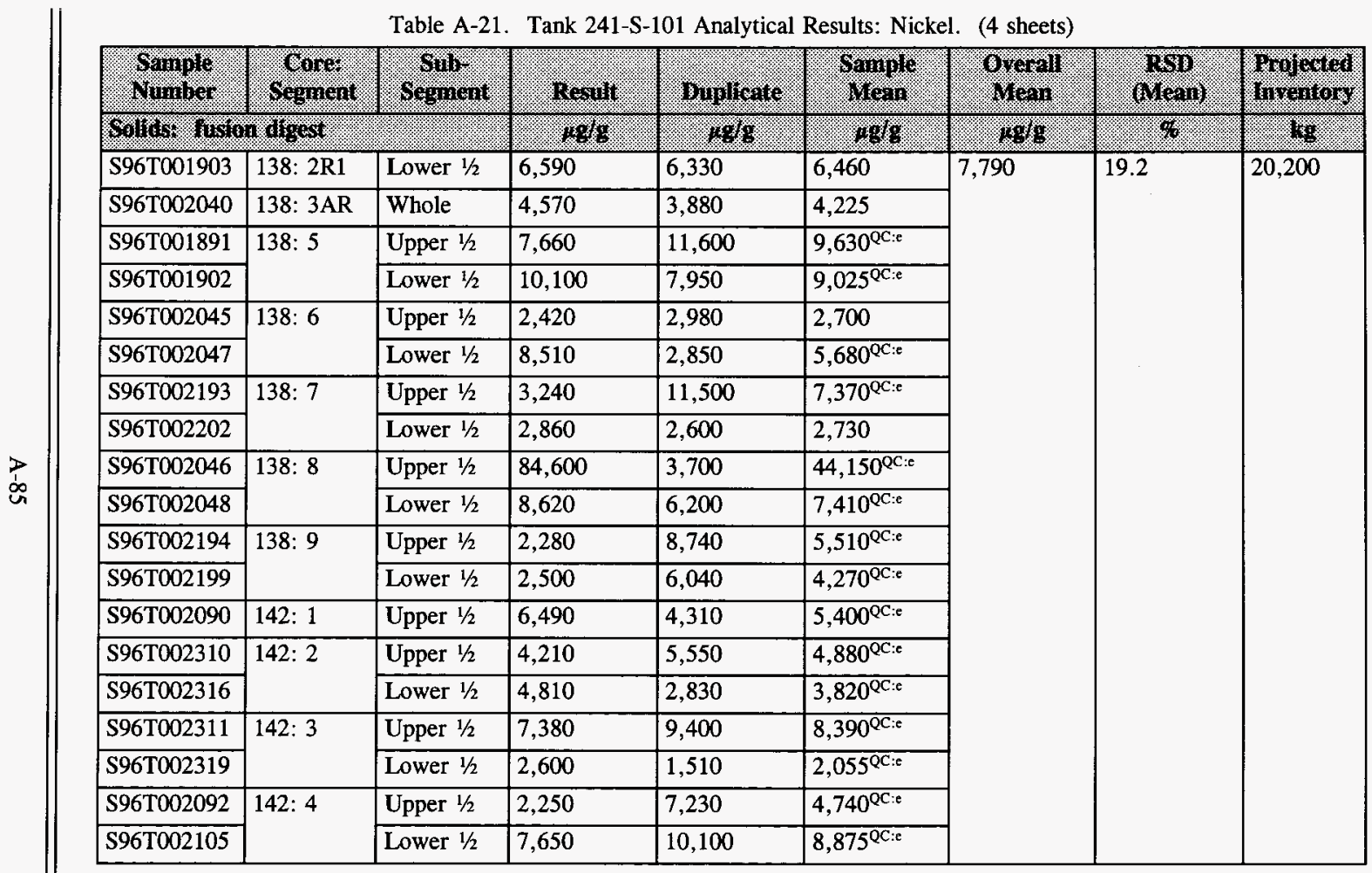


Table A-21. Tank 241-S-101 Analytical Results: Nickel. (4 sheets)

\begin{tabular}{|c|c|c|c|c|c|c|c|c|}
\hline Gompl & osport & 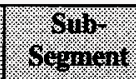 & herail & Wijalicale & WP11\%1 & (1) & (4) & 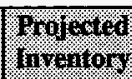 \\
\hline \multicolumn{3}{|c|}{ 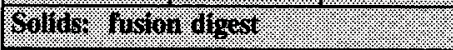 } & $10 \%$ & $w_{6}$ & $0 \%$ & (3) & $\%$ & ( $18 \mathrm{~B}$ \\
\hline S96T002093 & 142: 5 & Upper $1 / 2$ & 5,080 & 7,120 & $6,100^{\text {eC:e }}$ & \multirow[t]{8}{*}{ Cont. } & \multirow[t]{8}{*}{ Cont. } & \multirow[t]{8}{*}{ Cont. } \\
\hline S96T002106 & & Lower $1 / 2$ & 4,470 & 3,550 & $4,010^{\overline{Q C: e}}$ & & & \\
\hline S96T002094 & \multirow[t]{2}{*}{ 142: 6} & Upper $1 / 2$ & 13,200 & 10,300 & $11,750^{\text {QC:e }}$ & & & \\
\hline S96T002091 & & Lower $1 / 2$ & 6,050 & 14,300 & $10,175^{\text {QC:e }}$ & & & \\
\hline S96T002095 & \multirow[t]{2}{*}{$142: 7$} & Upper $1 / 2$ & 12,600 & 14,900 & 13,750 & & & \\
\hline S96T002107 & & Lower $1 / 2$ & 3,230 & 3,650 & 3,440 & & & \\
\hline S96T002096 & \multirow[t]{2}{*}{ 142: 8} & Upper $1 / 2$ & 9,490 & 4,590 & $7,040^{\mathrm{QC}: c}$ & & & \\
\hline S96T002108 & & Lower $1 / 2$ & 12,100 & 13,000 & 12,550 & & & \\
\hline \multicolumn{3}{|c|}{ Soldo acid digest } & $\% \%$ & 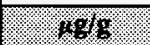 & 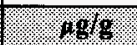 & 1018 & 20 & 1\%g \\
\hline S96T001905 & 138: 2R1 & Lower $1 / 2$ & 89.5 & 93.8 & 91.65 & \multirow[t]{12}{*}{89.9} & \multirow[t]{12}{*}{13.8} & \multirow[t]{12}{*}{233} \\
\hline S96T001892 & \multirow[t]{2}{*}{$138: 5$} & Upper $1 / 2$ & 56 & 59.6 & 57.8 & & & \\
\hline S96T001904 & & Lower $1 / 2$ & 65.2 & 71.8 & 68.5 & & & \\
\hline S96T002049 & \multirow[t]{2}{*}{$138: 6$} & Upper $1 / 2$ & 50.4 & 52.8 & 51.6 & & & \\
\hline S96T002050 & & Lower $1 / 2$ & 58 & 61.4 & 59.7 & & & \\
\hline S96T002195 & \multirow[t]{2}{*}{$138: 7$} & Upper $1 / 2$ & 67 & 64 & 65.5 & & & \\
\hline S96T002203 & & Lower $1 / 2$ & 71.7 & 80.6 & 76.15 & & & \\
\hline S96T002051 & \multirow[t]{2}{*}{ 138: 8} & Upper $1 / 2$ & 87.5 & 80.8 & 84.15 & & & \\
\hline S96T002052 & & Lower $1 / 2$ & 97.6 & 94.1 & 95.85 & & & \\
\hline S96T002196 & \multirow[t]{2}{*}{ 138: 9} & Upper $1 / 2$ & 154 & 158 & 156 & & & \\
\hline S96T002200 & & Lower $1 / 2$ & 39.7 & 39.4 & 39.55 & & & \\
\hline S96T002097 & 142: 1 & Upper $1 / 2$ & 135 & 132 & 133.5 & & & \\
\hline
\end{tabular}


Table A-21. Tank 241-S-101 Analytical Results: Nickel. (4 sheets)

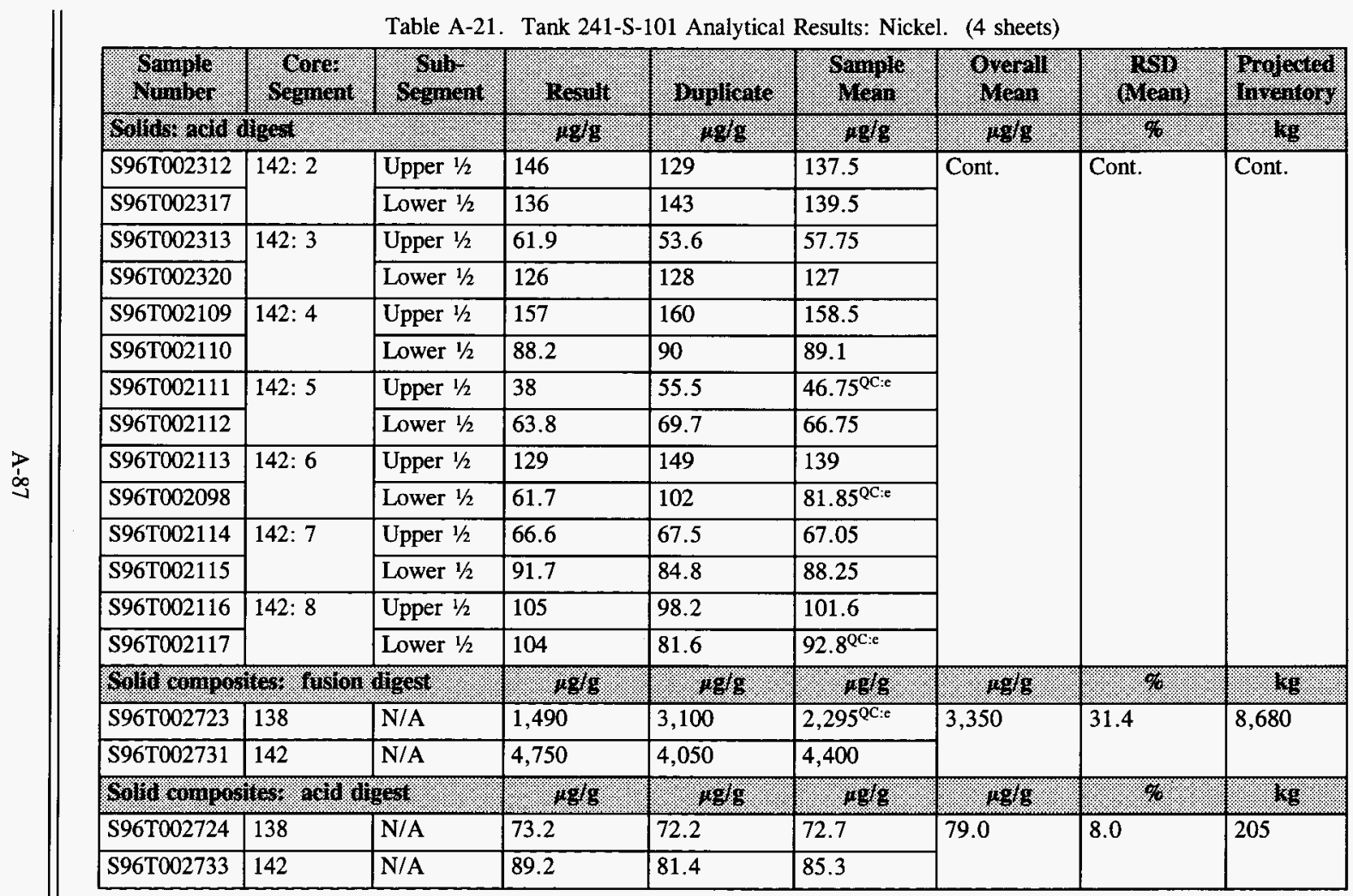


Table A-21. Tank 241-S-101 Analytical Results: Nickel. (4 sheets)

\begin{tabular}{|c|c|c|c|c|c|c|c|c|}
\hline Vanapl & ogrom & ogment & Tresint: & Buplicate & Hornof & $w_{10411}$ & 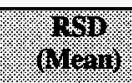 & Propor \\
\hline \multicolumn{3}{|c|}{ 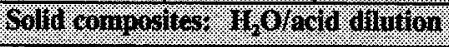 } & $48 / 9$ & 1.98 & $.48 \%$ & 18918 & \% & 48 \\
\hline S96T002726 & 138 & N/A & $<11.2$ & $<10.9$ & $<11.05$ & \multirow[t]{2}{*}{$<10.8$} & \multirow[t]{2}{*}{ N/A } & \multirow[t]{2}{*}{$<28.0$} \\
\hline \$96T002736 & 142 & N/A & $<11$ & $<10.1$ & $<10.55$ & & & \\
\hline \multicolumn{3}{|c|}{ Bronable Houlas } & 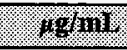 & (9) & womlar & $.961 \mathrm{~min}^{2}$ & \%? & Hs \\
\hline \$96T001886 & 138: 1R & $\mathrm{DL}$ & $<8.02$ & $<8.02$ & $<8.02$ & \multirow[t]{3}{*}{$<8.02$} & \multirow[t]{3}{*}{ N/A } & \multirow[t]{3}{*}{$<0.361$} \\
\hline S96T001909 & 138: $2 \mathrm{R} 1$ & $\overline{\mathrm{DL}}$ & $<8.02$ & $<8.02$ & $<8.02$ & & & \\
\hline S96T002043 & 138: 3R & DL & $<8.02$ & $<8.02$ & $<8.02$ & & & \\
\hline
\end{tabular}




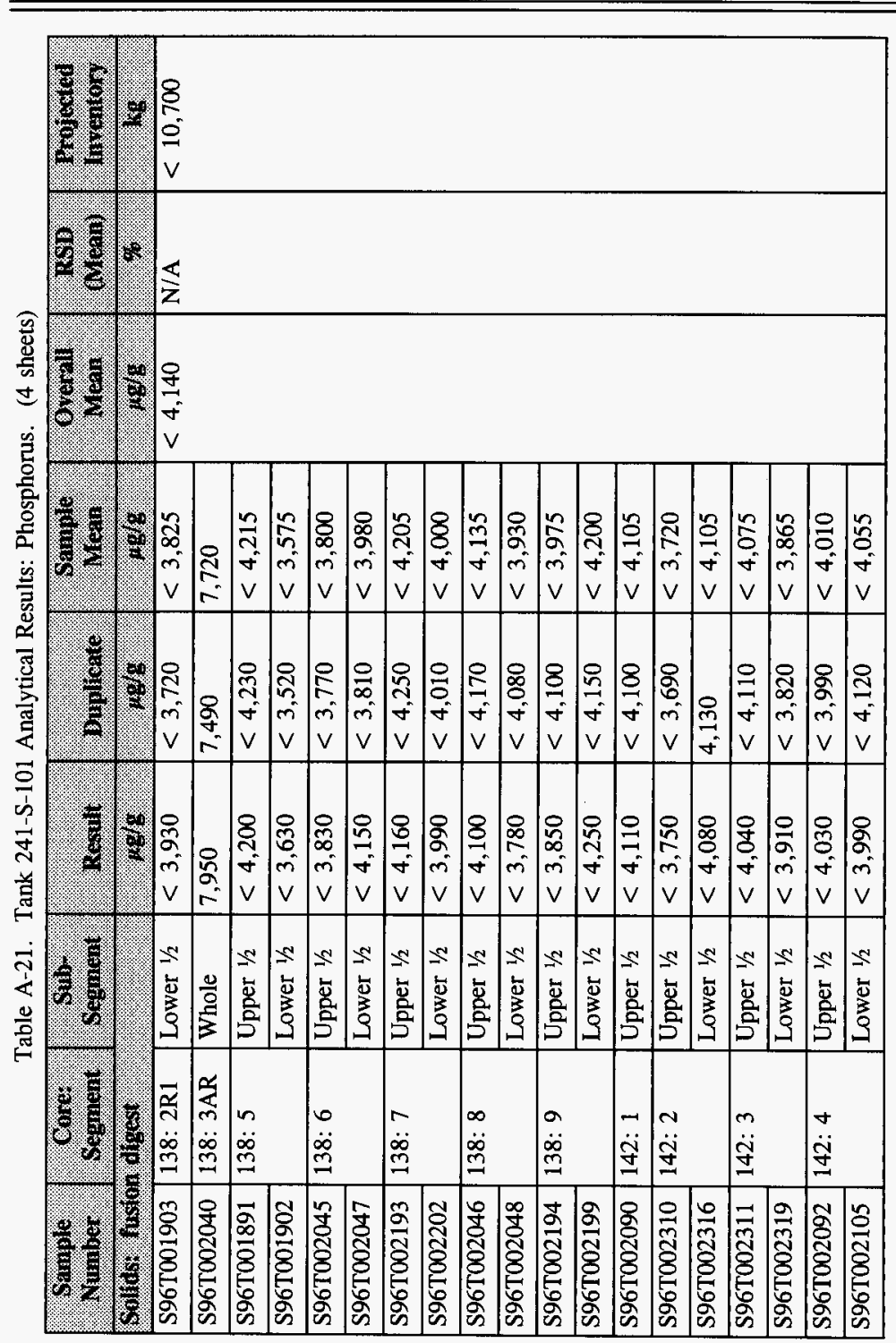


Table A-21. Tank 241-S-101 Analytical Results: Phosphorus. (4 sheets)

\begin{tabular}{|c|c|c|c|c|c|c|c|c|}
\hline gonol. & orgingat & orotinger & \% & ninilicale & Waingh & oroulu & 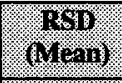 & moromorom \\
\hline \multicolumn{2}{|c|}{ 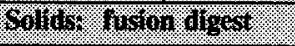 } & & 49 & $10 \%$ & 1096 & 1886 & $1 \%$ & 48 \\
\hline S96T002093 & \multirow[t]{2}{*}{$142: 5$} & Upper $1 / 2$ & $<3,870$ & $<3,740$ & $<3,805$ & \multirow[t]{8}{*}{ Cont. } & \multirow[t]{8}{*}{ Cont. } & \multirow[t]{8}{*}{ Cont. } \\
\hline S96T002106 & & Lower $1 / 2$ & $<4,090$ & $<3,750$ & $<3,920$ & & & \\
\hline S96T002094 & \multirow[t]{2}{*}{$142: 6$} & Upper $1 / 2$ & $<4,150$ & $<4,050$ & $<4,100$ & & & \\
\hline S96T002091 & & Lower $1 / 2$ & $<4,120$ & $<4,090$ & $<4,105$ & & & \\
\hline S96T002095 & \multirow[t]{2}{*}{ 142: 7} & Upper $1 / 2$ & $<3,970$ & $<4,010$ & $<3,990$ & & & \\
\hline S96T002107 & & Lower $1 / 2$ & $<4,290$ & $<4,350$ & $<4,320$ & & & \\
\hline S96T002096 & \multirow[t]{2}{*}{$142: 8$} & Upper $1 / 2$ & $<3,980$ & $<3,970$ & $<3,975$ & & & \\
\hline S96T002108 & & Lower $1 / 2$ & $<4,080$ & $<3,990$ & $<4,035$ & & & \\
\hline \multicolumn{3}{|c|}{ Wolfir row digert } & $198 \%$ & 1044 & 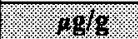 & 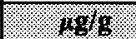 & $16 \% .1$. & 1. \\
\hline S96T001905 & 138: 2R1 & Lower $1 / 2$ & 1,930 & 1,940 & 1,935 & \multirow[t]{12}{*}{1,400} & \multirow[t]{12}{*}{24.5} & \multirow[t]{12}{*}{3,630} \\
\hline S96T001892 & \multirow[t]{2}{*}{$138: 5$} & Upper $1 / 2$ & 1,960 & 2,090 & 2,025 & & & \\
\hline S96T001904 & & Lower $1 / 2$ & 1,690 & 1,870 & 1,780 & & & \\
\hline S96T002049 & \multirow[t]{2}{*}{ 138: 6} & Upper $1 / 2$ & 1,400 & 1,510 & 1,455 & & & \\
\hline S96T002050 & & Lower $1 / 2$ & 1,220 & 1,280 & 1,250 & & & \\
\hline S96T002195 & \multirow[t]{2}{*}{ 138: 7} & Upper $1 / 2$ & 888 & 891 & 889.5 & & & \\
\hline \$96T002203 & & Lower $1 / 2$ & 622 & 677 & 649.5 & & & \\
\hline S96T002051 & \multirow[t]{2}{*}{ 138: 8} & Upper $1 / 2$ & 422 & 422 & 422 & & & \\
\hline S96T002052 & & Lower $1 / 2$ & 253 & 244 & 248.5 & & & \\
\hline S96T002196 & \multirow[t]{2}{*}{ 138: 9} & Upper $1 / 2$ & 119 & 111 & 115 & & & \\
\hline S96T002200 & & Lower $1 / 2$ & $<73.6$ & $<79.6$ & $<76.6$ & & & \\
\hline S96T002097 & 142: 1 & Upper $1 / 2$ & 1,990 & 1,800 & 1,895 & & & \\
\hline
\end{tabular}


Table A-21. Tank 241-S-101 Analytical Results: Phosphorus. (4 sheets)

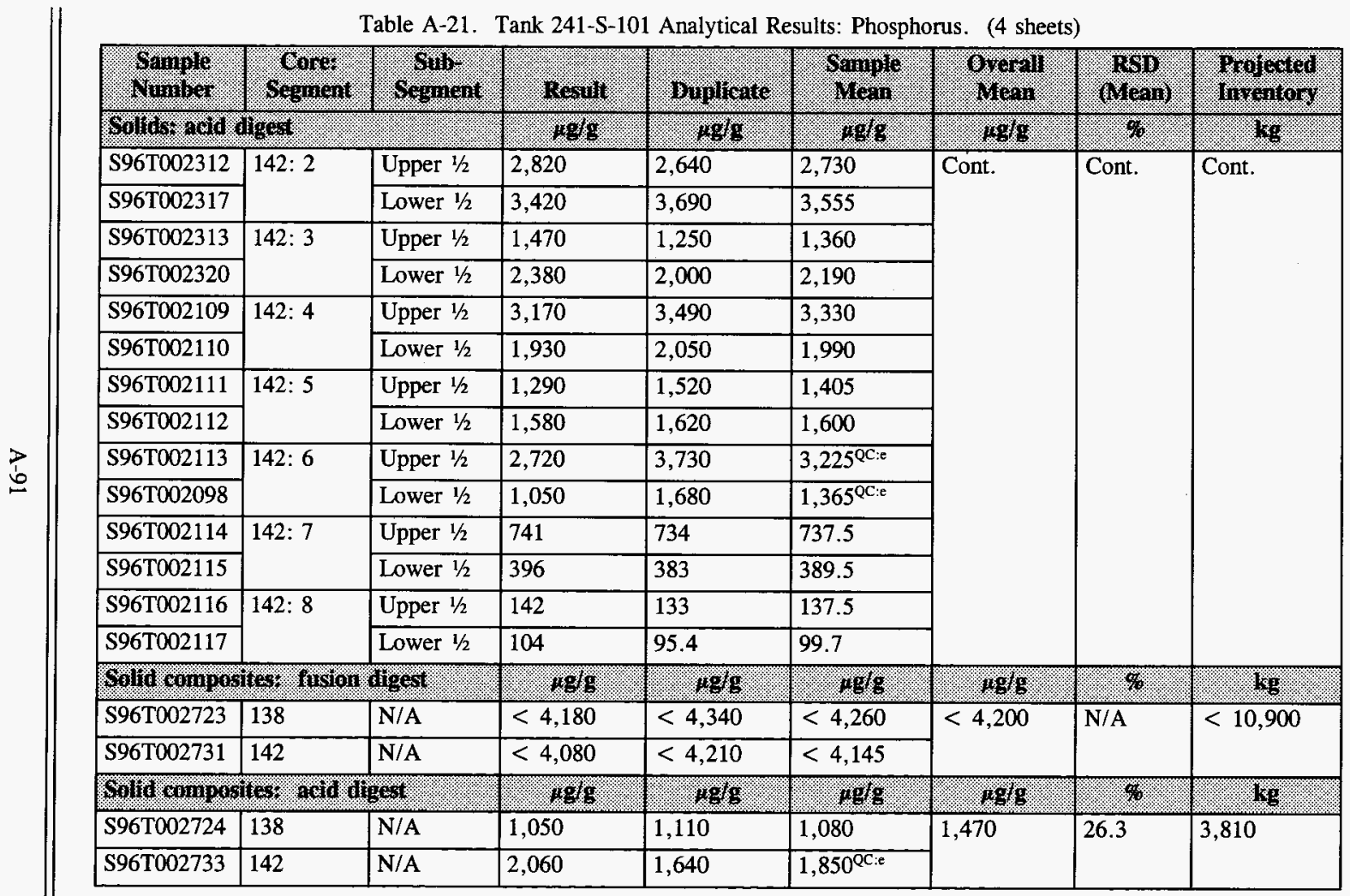


Table A-21. Tank 241-S-101 Analytical Results: Phosphorus. (4 sheets)

\begin{tabular}{|c|c|c|c|c|c|c|c|c|}
\hline Gamol & Woror & ochomol & $\mathrm{k}=$ - ill & 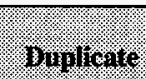 & 101010 & 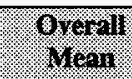 & $\begin{array}{l}\text { Rsil } \\
\text { (Menui) }\end{array}$ & moricat \\
\hline \multicolumn{3}{|c|}{ 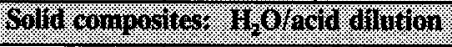 } & 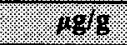 & 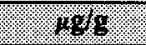 & 1068 & 1698 & \% & $\mathrm{kg}$ \\
\hline S96T002726 & 138 & N/A & 1,060 & 831 & $945.5^{\mathrm{QC}: \mathrm{e}}$ & \multirow[t]{2}{*}{1,290} & \multirow[t]{2}{*}{26.9} & \multirow[t]{2}{*}{3,340} \\
\hline S96T002736 & 142 & N/A & 2,070 & 1,210 & $1,640^{\mathrm{QC}: \mathrm{e}}$ & & & \\
\hline \multicolumn{3}{|c|}{ 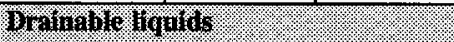 } & Wygln & (p) & 18.111 & 1801111 & $\%$ & 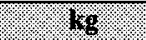 \\
\hline S96T001886 & 138: $1 \mathrm{R}$ & DL & 1,140 & 1,140 & 1,140 & \multirow[t]{3}{*}{1,260} & \multirow[t]{3}{*}{7.7} & \multirow[t]{3}{*}{56.7} \\
\hline S96T001909 & 138: 2R1 & DL & 1,180 & 1,190 & 1,185 & & & \\
\hline \$96T002043 & 138: $3 \mathrm{R}$ & DL & 1,450 & 1,450 & 1,450 & & & \\
\hline
\end{tabular}


Table A-22. Tank 241-S-101 Analytical Results: Potassium. (2 sheets)

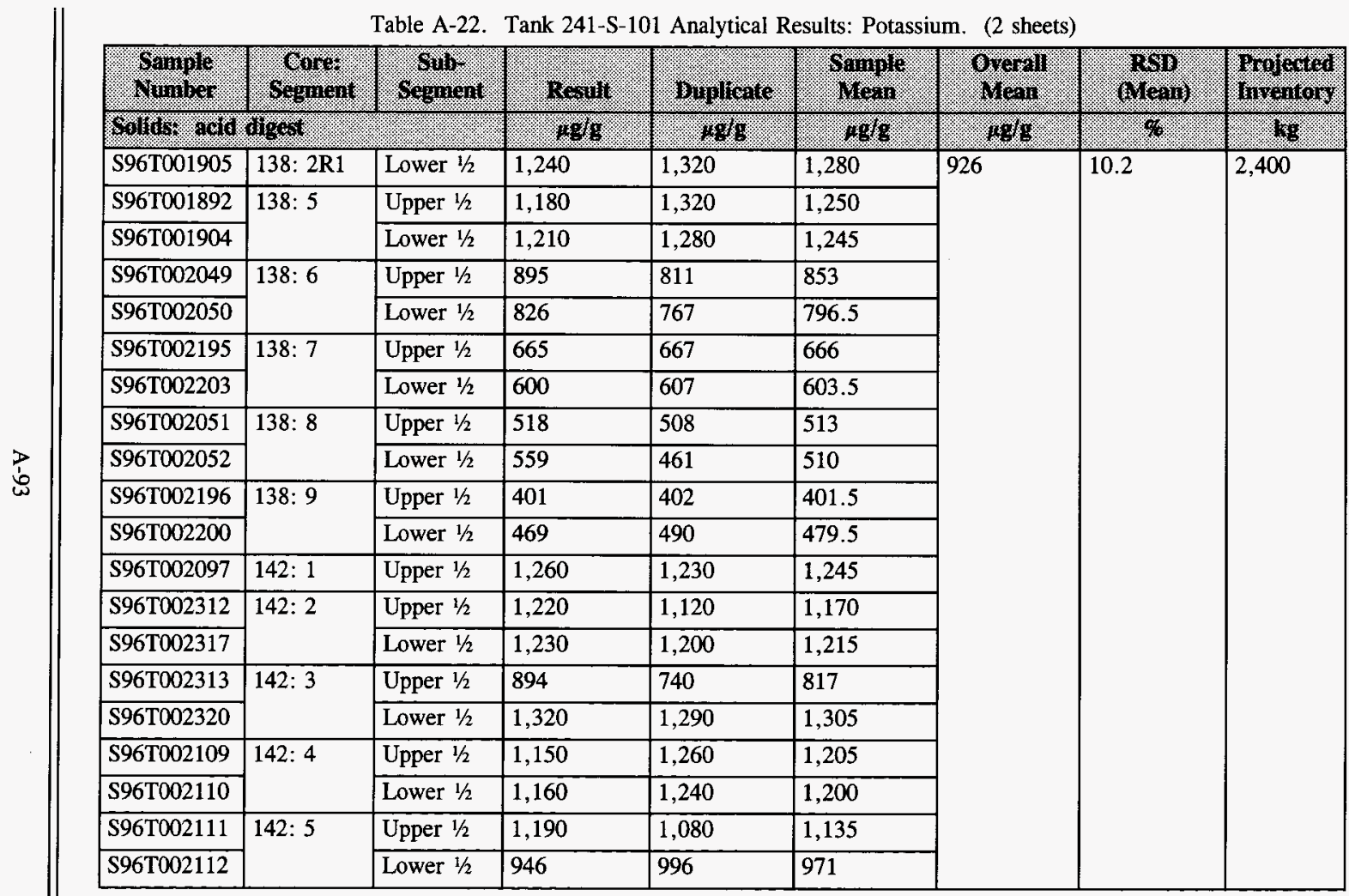


Table A-22. Tank 241-S-101 Analytical Results: Potassium. (2 sheets)

\begin{tabular}{|c|c|c|c|c|c|c|c|c|}
\hline 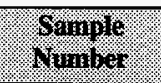 & $4 \%$ & 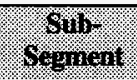 & Itesail & 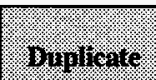 & $1 \%$ & Wyod & $\log 10$ & 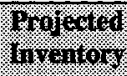 \\
\hline \multicolumn{3}{|c|}{ 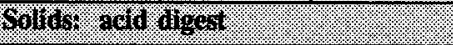 } & $4 \mathrm{SH}$ & $.8 \% 8$ & 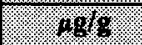 & 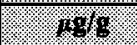 & \%. & 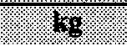 \\
\hline S96T002113 & 142: 6 & Upper 1/2 & 1,190 & 1,310 & 1,250 & \multirow[t]{5}{*}{ Cont. } & \multirow[t]{5}{*}{ Cont. } & \multirow[t]{5}{*}{ Cont. } \\
\hline S96T002098 & & Lower $1 / 2$ & 750 & 1,190 & $970^{\text {QC:e }}$ & & & \\
\hline \$96T002114 & 142: 7 & Upper $1 / 2$ & 732 & 760 & 746 & & & \\
\hline S96T002116 & \multirow[t]{2}{*}{ 142: 8} & Upper $1 / 2$ & 530 & 520 & 525 & & & \\
\hline S96T002117 & & Lower $1 / 2$ & 524 & 593 & 558.5 & & & \\
\hline \multicolumn{3}{|c|}{ 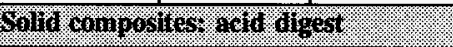 } & 6.496 & 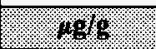 & (1.1\% & 498 & (1) & ige \\
\hline S96T002724 & 138 & N/A & 807 & 771 & 789 & 880 & 10.4 & 2,280 \\
\hline S96T002736 & 142 & N/A & 1,060 & 1,050 & 1,055 & 916 & 15.2 & 2,370 \\
\hline \multicolumn{3}{|c|}{ 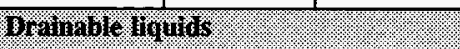 } & 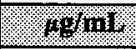 & . & $196 \mathrm{ml}$ & 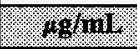 & \% & $.4 \mathrm{y}$ \\
\hline S96T001886 & 138: $1 \mathrm{R}$ & $\mathrm{DL}$ & 2,490 & 2,460 & 2,475 & \multirow[t]{3}{*}{2,360} & \multirow[t]{3}{*}{6.5} & \multirow[t]{3}{*}{106} \\
\hline \$96T001909 & 138: 2R1 & DL & 2,510 & 2,590 & 2,550 & & & \\
\hline \$96T002043 & 138: 3R & $\overline{\mathrm{DL}}$ & 2,010 & 2,100 & 2,055 & & & \\
\hline
\end{tabular}




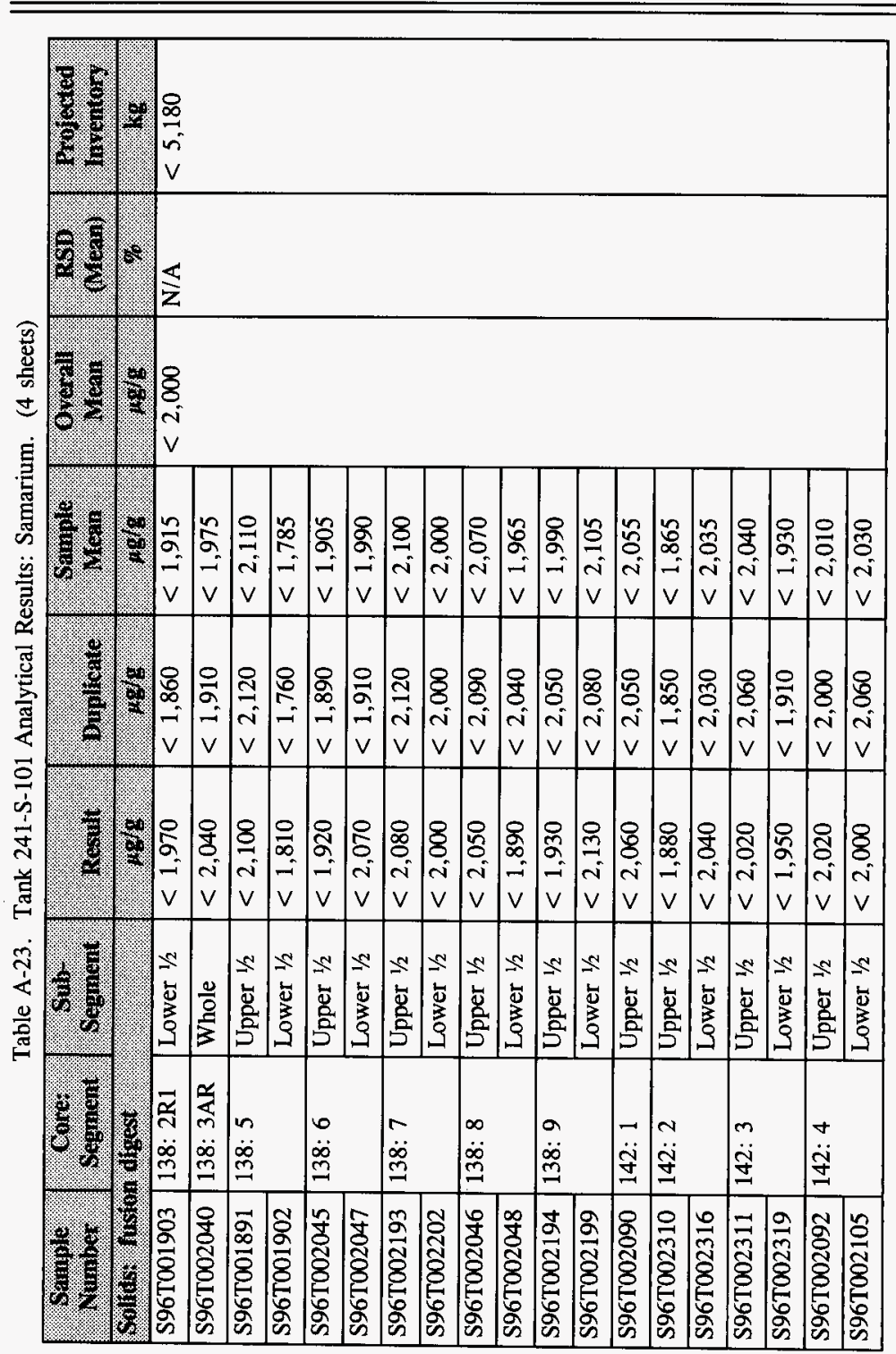


Table A-23. Tank 241-S-101 Analytical Results: Samarium. (4 sheets)

\begin{tabular}{|c|c|c|c|c|c|c|c|c|}
\hline Maninge & Sompr. & 6.prich & it. & Bullate & Monition. & Weroll & 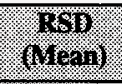 & 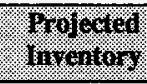 \\
\hline \multicolumn{2}{|c|}{ Hollust nurion ilgest: } & & 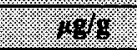 & 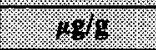 & (1.:. $.968 \%$ & $10 \% \mathrm{~g}$ & 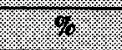 & (3. \\
\hline \$96T002093 & \multirow[t]{2}{*}{$142: 5$} & Upper $1 / 2$ & $<1,940$ & $<1,870$ & $<1,905$ & \multirow[t]{7}{*}{ Cont. } & \multirow[t]{7}{*}{ Cont. } & \multirow[t]{7}{*}{ Cont. } \\
\hline S96T002106 & & Lower $1 / 2$ & $<2,040$ & $<1,870$ & $<1,955$ & & & \\
\hline S96T002094 & 142: 6 & Upper $1 / 2$ & $<2,070$ & $<2,030$ & $<2,050$ & & & \\
\hline S96T002095 & \multirow[t]{2}{*}{$142: 7$} & Upper $1 / 2$ & $<1,990$ & $<2,010$ & $<2,000$ & & & \\
\hline S96T002107 & & Lower $1 / 2$ & $<2,150$ & $<2,170$ & $<2,160$ & & & \\
\hline S96T002096 & \multirow[t]{2}{*}{ 142: 8} & Upper $1 / 2$ & $<1,990$ & $<1,980$ & $<1,985$ & & & \\
\hline \$96T002108 & & Lower $1 / 2$ & $<2,040$ & $<2,000$ & $<2,020$ & & & \\
\hline S96T001904 & $138: 5$ & Lower $1 / 2$ & $<35.8$ & $<39.2$ & $<37.5$ & \multirow{9}{*}{$<38.7$} & \multirow{9}{*}{ N/A } & \multirow{9}{*}{$<100$} \\
\hline S96T002049 & \multirow[t]{2}{*}{ 138: 6} & Upper $1 / 2$ & $<37.6$ & $<38.9$ & $<38.25$ & & & \\
\hline S96T002050 & & Lower $1 / 2$ & $<37.1$ & $<40.9$ & $<39$ & & & \\
\hline \$96T002195 & \multirow[t]{2}{*}{ 138: 7} & Upper $1 / 2$ & $<44$ & $<44.9$ & $<44.45$ & & & \\
\hline \$96T002203 & & Lower $1 / 2$ & $<39.1$ & $<40.8$ & $<39.95$ & & & \\
\hline S96T002051 & \multirow[t]{2}{*}{$138: 8$} & Upper $1 / 2$ & $<36.9$ & $<38$ & $<37.45$ & & & \\
\hline S96T002052 & & Lower $1 / 2$ & $<37.9$ & $<39.1$ & $<38.5$ & & & \\
\hline \$96T002196 & \multirow[t]{2}{*}{ 138: 9} & Upper $1 / 2$ & $<36.9$ & $<36.4$ & $<36.65$ & & & \\
\hline$\$ 96 \mathrm{~T} 002200$ & & Lower $1 / 2$ & $<36.8$ & $<39.8$ & $<38.3$ & & & \\
\hline
\end{tabular}


Table A-23. Tank 241-S-101 Analytical Results: Samarium. (4 sheets)

\begin{tabular}{|c|c|c|c|c|c|c|c|c|}
\hline Momplot & 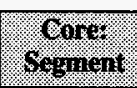 & ograngit & Rrgilit & Byplizalo. & (\%)in & 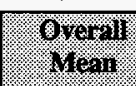 & $\begin{array}{l}\text { Fog } \\
\text { (6) }\end{array}$ & Mrourater \\
\hline \multicolumn{3}{|c|}{ 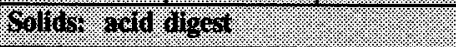 } & $1 \% 1 \%$ & $1.98 \%$ & 1968 & (3., 1968 & $\% \%$ & 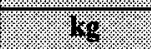 \\
\hline S96T002312 & $142: 2$ & Upper $1 / 2$ & $<40.9$ & $<36.8$ & $<38.85$ & \multirow[t]{9}{*}{ Cont. } & \multirow[t]{9}{*}{ Cont. } & \multirow[t]{9}{*}{ Cont. } \\
\hline S96T002317 & & Lower $1 / 2$ & $<37.3$ & $<39.1$ & $<38.2$ & & & \\
\hline S96T002109 & \multirow[t]{2}{*}{ 142: 4} & Upper $1 / 2$ & $<40.1$ & $<40.9$ & $<40.5$ & & & \\
\hline S96T002110 & & Lower $1 / 2$ & $<39.3$ & $<38.6$ & $<38.95$ & & & \\
\hline \$96T002111 & \multirow[t]{2}{*}{ 142: 5} & Upper $1 / 2$ & $<35.3$ & $<38.6$ & $<36.95$ & & & \\
\hline S96T002112 & & Lower $1 / 2$ & $<35.7$ & $<38.2$ & $<36.95$ & & & \\
\hline S96T002115 & $142: 7$ & Lower $1 / 2$ & $<36.7$ & $<35.8$ & $<36.25$ & & & \\
\hline \$96T002116 & \multirow[t]{2}{*}{$142: 8$} & Upper $1 / 2$ & $<37.1$ & $<36$ & $<36.55$ & & & \\
\hline S96T002117 & & Lower $1 / 2$ & $<37.5$ & $<37$ & $<37.25$ & & & \\
\hline \multicolumn{3}{|c|}{ Wold composites t rusion ifigest } & $.1 .9 \mathrm{~g}_{\mathrm{S}}$ & .49 & . & 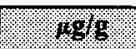 & \% & 6.tog \\
\hline S96T002723 & 138 & N/A & $<2,090$ & $<2,170$ & $<2,130$ & \multirow[t]{2}{*}{$<2,100$} & \multirow[t]{2}{*}{ N/A } & \multirow[t]{2}{*}{$<5,440$} \\
\hline S96T002731 & 142 & N/A & $<2,040$ & $<2,100$ & $<2,070$ & & & \\
\hline \multicolumn{3}{|c|}{ 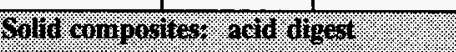 } & .898 & . & 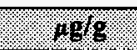 & $19 \mathrm{~g} g$ & (1) & 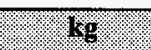 \\
\hline S96T002724 & 138 & $\mathrm{~N} / \mathrm{A}$ & $<68.6$ & $<68.2$ & $<68.4$ & \multirow[t]{2}{*}{$<67.0$} & \multirow[t]{2}{*}{ N/A } & \multirow[t]{2}{*}{$<174$} \\
\hline S96T002733 & 142 & $\mathrm{~N} / \mathrm{A}$ & $<67.7$ & $<63.5$ & $<65.6$ & & & \\
\hline
\end{tabular}


Table A-23. Tank 241-S-101 Analytical Results: Samarium. (4 sheets)

\begin{tabular}{|c|c|c|c|c|c|c|c|c|}
\hline $\begin{array}{l}\text { Gample: } \\
\text { Tumber. }\end{array}$ & $\begin{array}{l}\text { Corre? } \\
\text { Segment }\end{array}$ & $\begin{array}{l}\text { Sillit. } \\
\text { Segrnent }\end{array}$ & Pesuit & Guplogie: & $\begin{array}{l}\text { Sarrolle } \\
\text { Mean }\end{array}$ & $\begin{array}{l}\text { Oycrall } \\
\text { vear }\end{array}$ & $\begin{array}{l}\text { RST } \\
\text { (Near })\end{array}$ & Irroguged \\
\hline \multicolumn{3}{|c|}{ 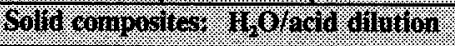 } & 1988 & $198 / 8$ & 48 & 1498 & 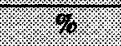 & 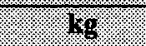 \\
\hline S96T002726 & 138 & N/A & $<56.2$ & $<54.6$ & $<55.4$ & \multirow[t]{2}{*}{$<54.0$} & \multirow[t]{2}{*}{$\mathrm{N} / \mathrm{A}$} & \multirow[t]{2}{*}{$<140$} \\
\hline S96T002736 & 142 & N/A & $<54.8$ & $<50.4$ & $<52.6$ & & & \\
\hline \multicolumn{3}{|c|}{ Dramable liquifis: } & 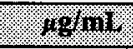 & 18. min: & 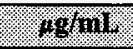 & $4 \mathrm{~g} / \mathrm{m}$ & 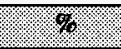 & $1.1 \mathrm{~kg}$ \\
\hline S96T001886 & 138: $1 \mathrm{R}$ & DL & $<40.1$ & $<40.1$ & $<40.1$ & \multirow{3}{*}{$<40.1$} & \multirow[t]{3}{*}{ N/A } & \multirow[t]{3}{*}{$<1.80$} \\
\hline S96T001909 & 138: $2 \mathrm{R} 1$ & DL & $<40.1$ & $<40.1$ & $<40.1$ & & & \\
\hline S96T002043 & 138: $3 \mathrm{R}$ & DL & $<40.1$ & $<40.1$ & $<40.1$ & & & \\
\hline
\end{tabular}




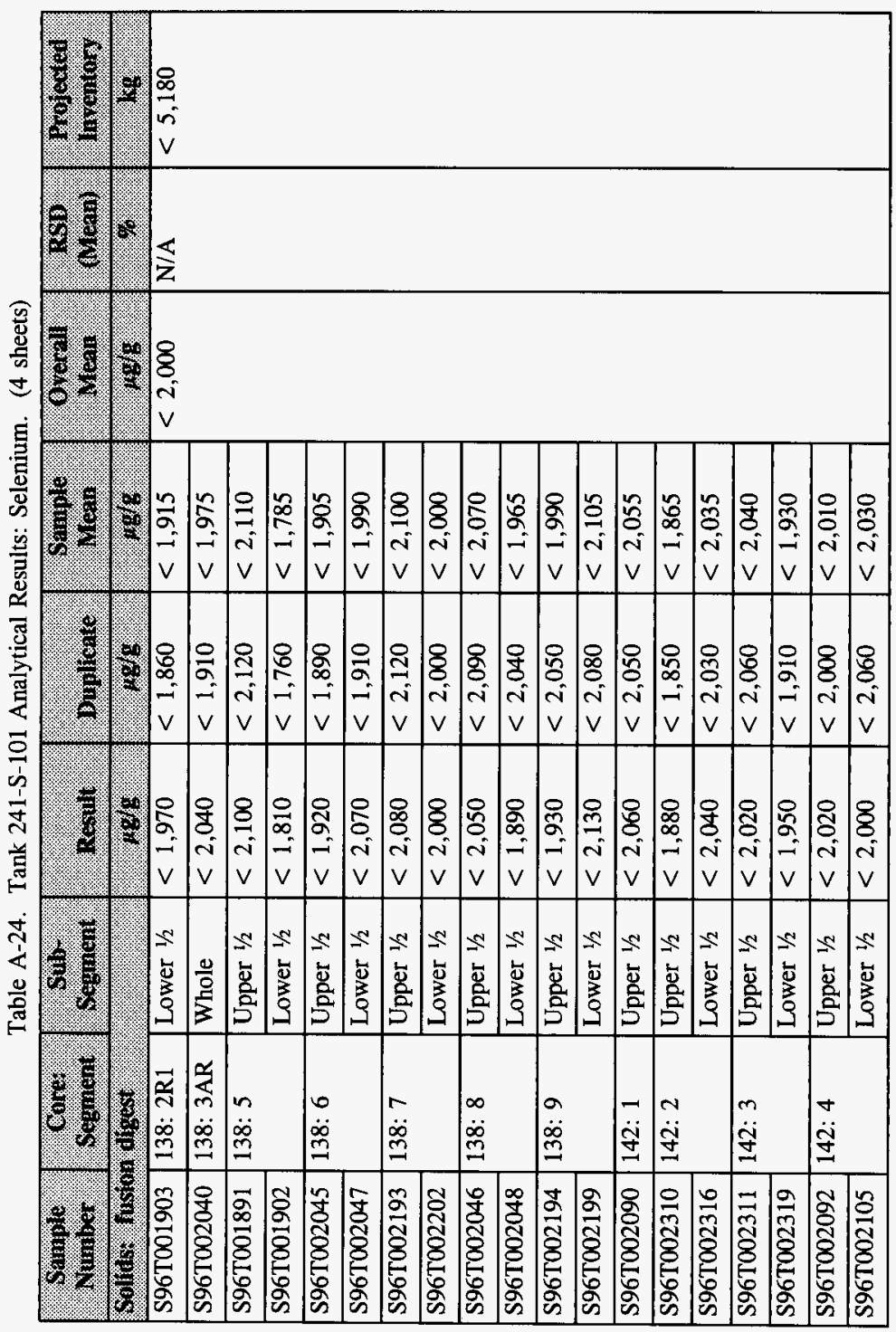


Table A-24. Tank 241-S-101 Analytical Results: Selenium. (4 sheets)

\begin{tabular}{|c|c|c|c|c|c|c|c|c|}
\hline $\begin{array}{l}\text { Cample } \\
\text { Number. }\end{array}$ & Somernent & Sombint & Rerwil & Buplicate & Sorrole & $\begin{array}{l}\text { Operall } \\
\text { Wean }\end{array}$ & $\begin{array}{l}\text { Resi } \\
\text { Mrani }\end{array}$ & $\begin{array}{l}\text { Trojected } \\
\text { Inventory }\end{array}$ \\
\hline \multicolumn{3}{|c|}{ Solvor Tistondigest: } & $198 \mathrm{~g}$ & 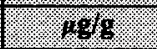 & 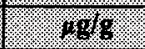 & .1868 & 9.9 .9 & 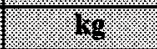 \\
\hline S96T002093 & \multirow[t]{2}{*}{$142: 5$} & Upper $1 / 2$ & $<1,940$ & $<1,870$ & $<1,905$ & \multirow[t]{8}{*}{ Cont. } & \multirow[t]{8}{*}{ Cont. } & \multirow[t]{8}{*}{ Cont. } \\
\hline S96T002106 & & Lower $1 / 2$ & $<2,040$ & $<1,870$ & $<1,955$ & & & \\
\hline S96T002094 & \multirow[t]{2}{*}{$142: 6$} & Upper $1 / 2$ & $<2,070$ & $<2,030$ & $<2,050$ & & & \\
\hline S96T002091 & & Lower $1 / 2$ & $<2,060$ & $<2,050$ & $<2,055$ & & & \\
\hline S96T002095 & \multirow[t]{2}{*}{$142: 7$} & Upper $1 / 2$ & $<1,990$ & $<2,010$ & $<2,000$ & & & \\
\hline S96T002107 & & Lower $1 / 2$ & $<2,150$ & $<2,170$ & $<2,160$ & & & \\
\hline S96T002096 & \multirow[t]{2}{*}{$142: 8$} & Upper $1 / 2$ & $<1,990$ & $<1,980$ & $<1,985$ & & & \\
\hline S96T002108 & & Lower $1 / 2$ & $<2,040$ & $<2,000$ & $<2,020$ & & & \\
\hline \multicolumn{3}{|c|}{ Solides arid olgert } & $14 \mathrm{gg}$ & 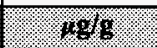 & . .96 & 1.978 & 9: & $\mathrm{kg}$ \\
\hline S96T001905 & 138: 2R1 & Lower $1 / 2$ & $<38.1$ & $<38.7$ & $<38.4$ & \multirow[t]{12}{*}{$<38.7$} & \multirow[t]{12}{*}{ N/A } & \multirow[t]{12}{*}{$<100$} \\
\hline S96T001892 & \multirow[t]{2}{*}{$138: 5$} & Upper $1 / 2$ & $<38.2$ & $<40.3$ & $<39.25$ & & & \\
\hline S96T001904 & & Lower $1 / 2$ & $<35.8$ & $<39.2$ & $<37.5$ & & & \\
\hline S96T002049 & \multirow[t]{2}{*}{$138: 6$} & Upper $1 / 2$ & $<37.6$ & $<38.9$ & $<38.25$ & & & \\
\hline S96T002050 & & \begin{tabular}{|l|} 
Lower $1 / 2$ \\
\end{tabular} & $<37.1$ & $<40.9$ & $<39$ & & & \\
\hline S96T002195 & \multirow[t]{2}{*}{$138: 7$} & Upper $1 / 2$ & $<44$ & $<44.9$ & $<44.45$ & & & \\
\hline S96T002203 & & Lower $1 / 2$ & $<39.1$ & $<40.8$ & $<39.95$ & & & \\
\hline S96T002051 & \multirow[t]{2}{*}{ 138: 8} & Upper $1 / 2$ & $<36.9$ & $<38$ & $<37.45$ & & & \\
\hline S96T002052 & & Lower $1 / 2$ & $<37.9$ & $<39.1$ & $<38.5$ & & & \\
\hline S96T002196 & \multirow[t]{2}{*}{ 138: 9} & Upper $1 / 2$ & $<36.9$ & $<36.4$ & $<36.65$ & & & \\
\hline S96T002200 & & Lower $1 / 2$ & $<36.8$ & $<39.8$ & $<38.3$ & & & \\
\hline S96T002097 & $142: 1$ & Upper $1 / 2$ & $<35.7$ & $<35.7$ & $<35.7$ & & & \\
\hline
\end{tabular}


Table A-24. Tank 241-S-101 Analytical Results: Selenium. (4 sheets)

\begin{tabular}{|c|c|c|c|c|c|c|c|c|}
\hline Sample & Gorrort & oyegnert & Keruil & Gunlicate & 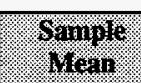 & Woroll & 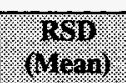 & 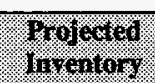 \\
\hline \multicolumn{2}{|c|}{ 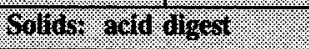 } & (2) & 496 & $1889=$ & 48 & $\log _{18}$ & $1 \% \%$ & 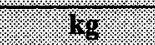 \\
\hline S96T002312 & $142: 2$ & Upper $1 / 2$ & $<40.9$ & $<36.8$ & $<38.85$ & \multirow{14}{*}{ Cont. } & \multirow[t]{14}{*}{ Cont. } & \multirow[t]{14}{*}{ Cont. } \\
\hline$\$ 96 \mathrm{~T} 002317$ & & Lower $1 / 2$ & $<37.3$ & $<39.1$ & $<38.2$ & & & \\
\hline S96T002313 & \multirow[t]{2}{*}{$142: 3$} & Upper $1 / 2$ & $<41$ & $<40.5$ & $<40.75$ & & & \\
\hline S96T002320 & & Lower $1 / 2$ & $<41.7$ & $<40.1$ & $<40.9$ & & & \\
\hline S96T002109 & \multirow[t]{2}{*}{$142: 4$} & Upper $1 / 2$ & $<40.1$ & $<40.9$ & $<40.5$ & & & \\
\hline S96T002110 & & Lower $1 / 2$ & $<39.3$ & $<38.6$ & $<38.95$ & & & \\
\hline S96T002111 & \multirow[t]{2}{*}{$142: 5$} & Upper $1 / 2$ & $<35.3$ & $<38.6$ & $<36.95$ & & & \\
\hline S96T002112 & & Lower $1 / 2$ & $<35.7$ & $<38.2$ & $<36.95$ & & & \\
\hline S96T002113 & \multirow[t]{2}{*}{ 142: 6} & Upper $1 / 2$ & $<38.9$ & $<44.8$ & $<41.85$ & & & \\
\hline S96T002098 & & Lower $1 / 2$ & $<39.3$ & $<40.8$ & $<40.05$ & & & \\
\hline S96T002114 & \multirow[t]{2}{*}{ 142: 7} & Upper $1 / 2$ & $<39.6$ & $<40.2$ & $<39.9$ & & & \\
\hline S96T002115 & & Lower $1 / 2$ & $<36.7$ & $<35.8$ & $<36.25$ & & & \\
\hline S96T002116 & \multirow[t]{2}{*}{ 142: 8} & Upper $1 / 2$ & $<37.1$ & $<36$ & $<\overline{36.55}$ & & & \\
\hline S96T002117 & & Lower $1 / 2$ & $<37.5$ & $<37$ & $<37.25$ & & & \\
\hline \multicolumn{3}{|c|}{ 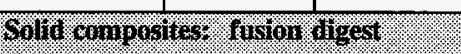 } & .149 & 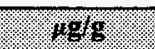 & 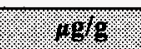 & 10910 & $8 \%$ & $1.9 \mathrm{~kg}$ \\
\hline S96T002723 & 138 & N/A & $<2,090$ & $<2,170$ & $<2,130$ & \multirow{2}{*}{$<2,100$} & \multirow[t]{2}{*}{ N/A } & \multirow[t]{2}{*}{$<5,180$} \\
\hline S96T002731 & 142 & N/A & $<2,040$ & $<2,100$ & $<2,070$ & & & \\
\hline \multicolumn{3}{|c|}{ 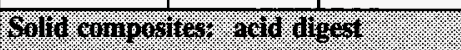 } & 4.998 & (2) & 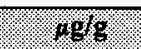 & 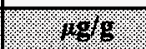 & $\%$ & 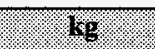 \\
\hline S96T002724 & 138 & N/A & $<68.6$ & $<68.2$ & $<68.4$ & \multirow[t]{2}{*}{$<67.0$} & \multirow[t]{2}{*}{$\mathrm{N} / \mathrm{A}$} & \multirow[t]{2}{*}{$<174$} \\
\hline S96T002733 & 142 & N/A & $<67.7$ & $<63.5$ & $<65.6$ & & & \\
\hline
\end{tabular}


Table A-24. Tank 241-S-101 Analytical Results: Selenium. (4 sheets)

\begin{tabular}{|c|c|c|c|c|c|c|c|c|}
\hline Waingo & opynsin & owpring & iterait & Bullicate & Monol & Worth & 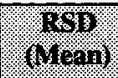 & Impentors \\
\hline \multicolumn{3}{|c|}{ 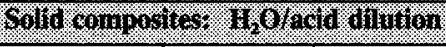 } & 148 & 1898 & 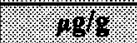 & $130 \%$ & $\%$ & 6. \\
\hline S96T002726 & 138 & N/A & $<56.2$ & $<54.6$ & $<55.4$ & \multirow[t]{2}{*}{$<54.0$} & \multirow[t]{2}{*}{$\mathrm{N} / \mathrm{A}$} & \multirow[t]{2}{*}{$<140$} \\
\hline S96T002736 & 142 & N/A & $<54.8$ & $<50.4$ & $<52.6$ & & & \\
\hline \multicolumn{3}{|c|}{ Bronalo Hants } & .94inu & 1094111 & 10941 & 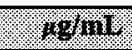 & 6\% & 18 \\
\hline S96T001886 & 138: $1 \mathrm{R}$ & DL & $<40.1$ & $<40.1$ & $<40.1$ & \multirow[t]{3}{*}{$<43.0$} & \multirow[t]{3}{*}{ N/A } & \multirow[t]{3}{*}{$<1.94$} \\
\hline S96T001909 & 138: 2R1 & $\mathrm{DL}$ & $<40.1$ & $<40.1$ & $<40.1$ & & & \\
\hline S96T002043 & 138: $3 \mathrm{R}$ & DL & 52.7 & 44.7 & 48.7 & & & \\
\hline
\end{tabular}




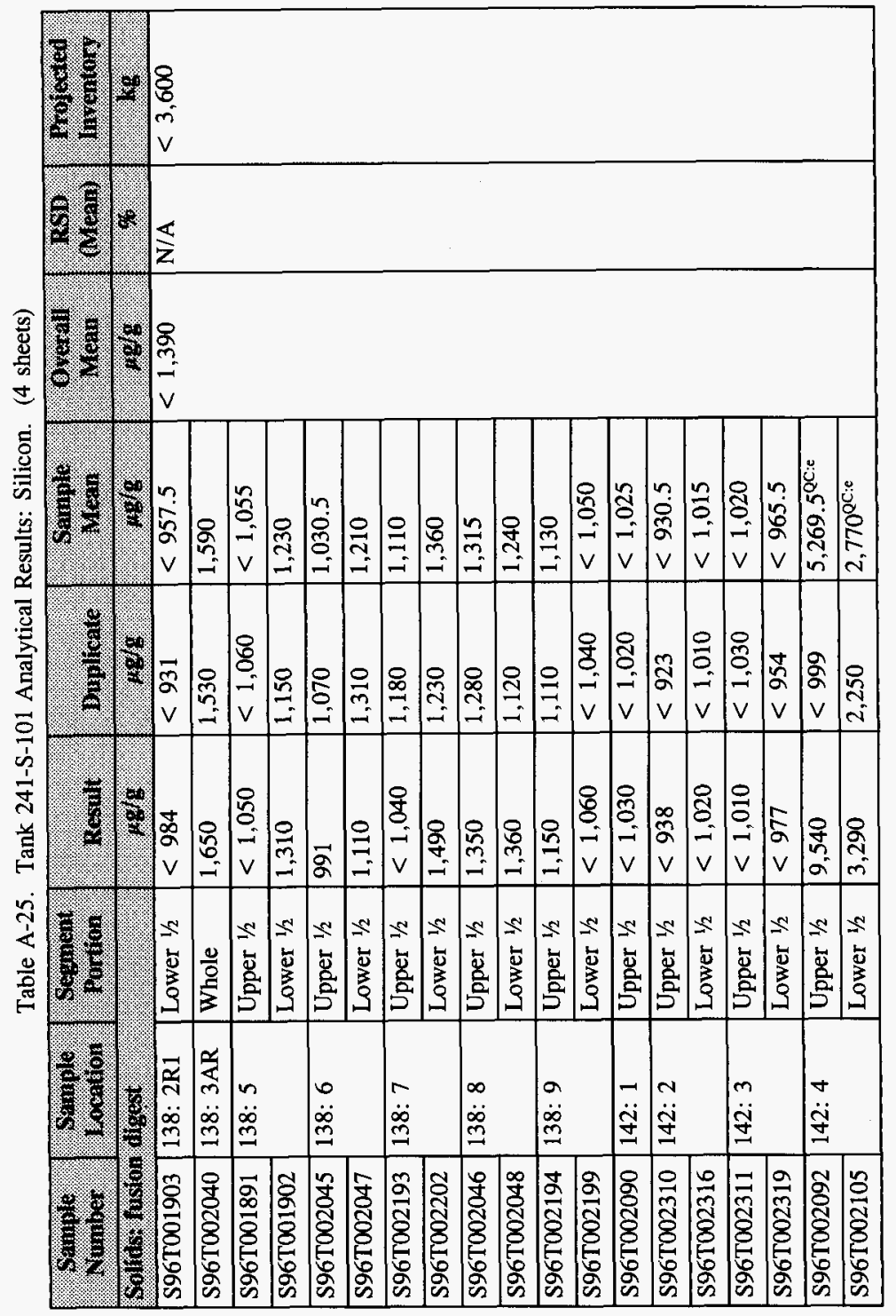


Table A-25. Tank 241-S-101 Analytical Results: Silicon. (4 sheets)

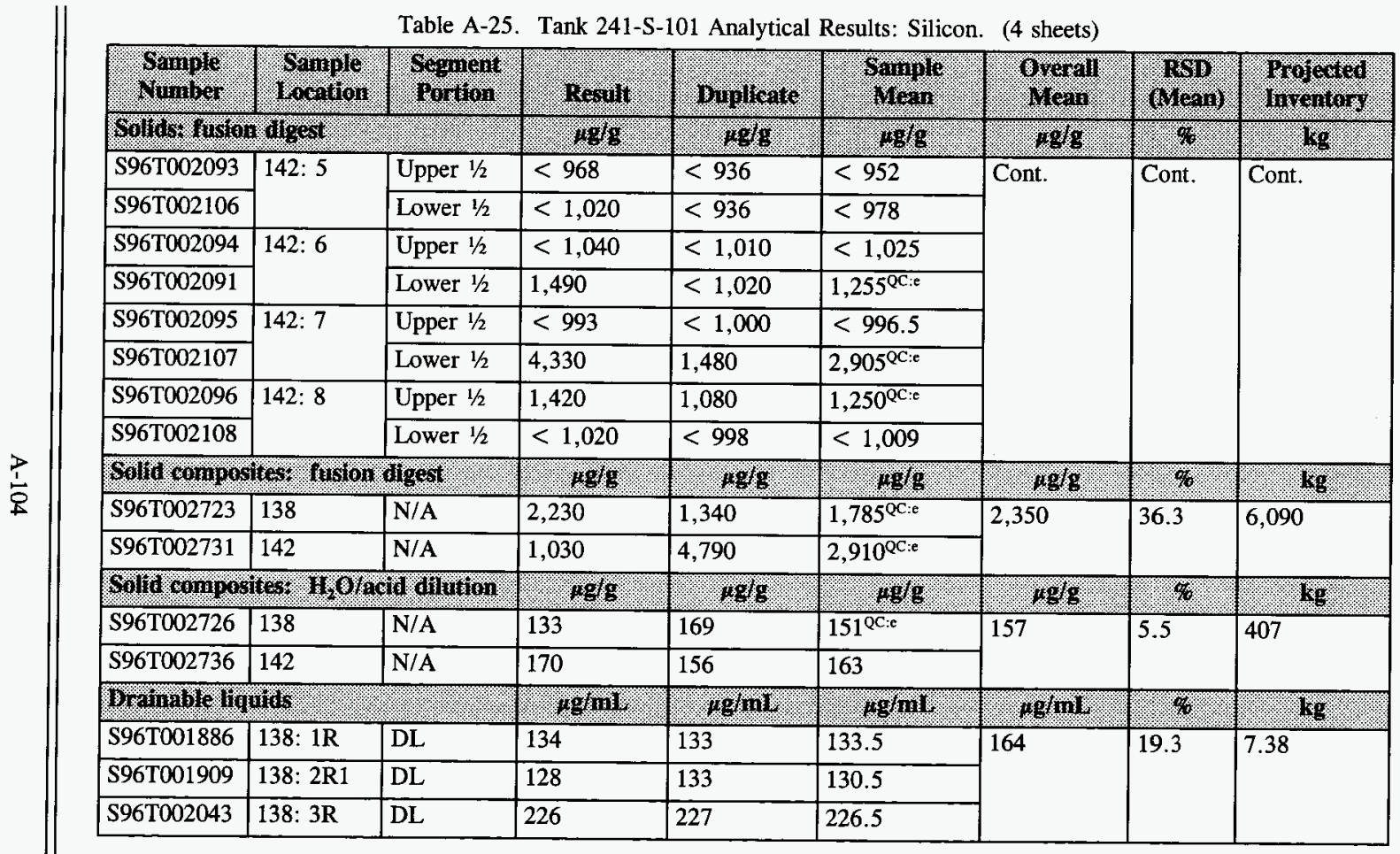


Table A-26. Tank 241-S-101 Analytical Results: Silver. (4 sheets)

\begin{tabular}{|c|c|c|c|c|c|c|c|c|}
\hline 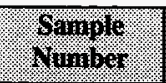 & owoment & 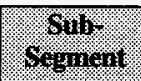 & Terril & 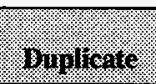 & Sogne & Whoril & $(1 / 4)$ & 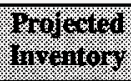 \\
\hline \multicolumn{3}{|c|}{ 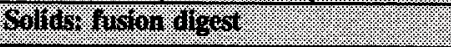 } & 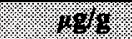 & 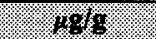 & $48 \%$ & 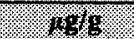 & $3 \%$ & (6) \\
\hline S96T001903 & 138: $2 \mathrm{R} 1$ & Lower $1 / 2$ & $<197$ & $<186$ & $<191.5$ & \multirow{21}{*}{$<200$} & \multirow[t]{21}{*}{ N/A } & \multirow[t]{21}{*}{$<518$} \\
\hline S96T002040 & 138: $3 \mathrm{AR}$ & Whole & $<204$ & $<191$ & $<197.5$ & & & \\
\hline S96T001891 & \multirow[t]{2}{*}{ 138: 5} & Upper $1 / 2$ & $<210$ & $<212$ & $<211$ & & & \\
\hline S96T001902 & & Lower $1 / 2$ & $<181$ & $<176$ & $<178.5$ & & & \\
\hline S96T002045 & \multirow[t]{2}{*}{ 138: 6} & Upper $1 / 2$ & $<192$ & $<189$ & $<190.5$ & & & \\
\hline S96T002047 & & Lower $1 / 2$ & $<207$ & $<191$ & $<199$ & & & \\
\hline S96T002193 & \multirow[t]{2}{*}{ 138: 7} & Upper $1 / 2$ & $<208$ & $<212$ & $<210$ & & & \\
\hline S96T002202 & & Lower $1 / 2$ & $<200$ & $<200$ & $<200$ & & & \\
\hline S96T002046 & \multirow[t]{2}{*}{ 138: 8} & Upper $1 / 2$ & $<205$ & $<209$ & $<207$ & & & \\
\hline S96T002048 & & Lower $1 / 2$ & $<189$ & $<204$ & $<196.5$ & & & \\
\hline S96T002194 & \multirow[t]{2}{*}{ 138: 9} & Upper $1 / 2$ & $<193$ & $<205$ & $<199$ & & & \\
\hline S96T002199 & & Lower $1 / 2$ & $<213$ & $<208$ & $<210.5$ & & & \\
\hline S96T002090 & $142: 1$ & Upper $1 / 2$ & $<206$ & $<205$ & $<205.5$ & & & \\
\hline S96T002310 & \multirow[t]{2}{*}{ 142: 2} & Upper $1 / 2$ & $<188$ & $<185$ & $<186.5$ & & & \\
\hline S96T002316 & & Lower $1 / 2$ & $<204$ & $<203$ & $<203.5$ & & & \\
\hline S96T002311 & \multirow[t]{2}{*}{$142: 3$} & Upper $1 / 2$ & $<202$ & $<206$ & $<204$ & & & \\
\hline S96T002319 & & Lower $1 / 2$ & $<195$ & $<191$ & $<193$ & & & \\
\hline S96T002092 & \multirow[t]{2}{*}{ 142: 4} & Upper $1 / 2$ & $<202$ & $<200$ & $<201$ & & & \\
\hline S96T002105 & & Lower $1 / 2$ & $<200$ & $<206$ & $<203$ & & & \\
\hline S96T002093 & \multirow[t]{2}{*}{$142: 5$} & Upper $1 / 2$ & $<194$ & $<187$ & $<190.5$ & & & \\
\hline S96T002106 & & Lower $1 / 2$ & $<204$ & $<187$ & $<195.5$ & & & \\
\hline
\end{tabular}


Table A-26. Tank 241-S-101 Analytical Results: Silver. (4 sheets)

\begin{tabular}{|c|c|c|c|c|c|c|c|c|}
\hline Qhmol & Whor & sopmont & Whyly & Binjeriso & 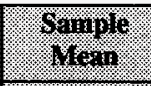 & orall & $\begin{array}{l}(1 \mathrm{sin} \\
(1 \mathrm{gan})\end{array}$ & Droldou \\
\hline \multicolumn{3}{|c|}{ 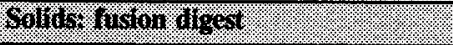 } & $4.4 \%$ & $1.6 \%$. & (1. & 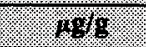 & 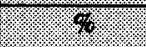 & 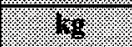 \\
\hline S96T002094 & \multirow[t]{2}{*}{ 142: 6} & Upper $1 / 2$ & $<207$ & $<203$ & $<205$ & \multirow[t]{5}{*}{ Cont. } & \multirow[t]{5}{*}{ Cont. } & \multirow[t]{5}{*}{ Cont. } \\
\hline S96T002091 & & Lower $1 / 2$ & $<206$ & $<205$ & $<205.5$ & & & \\
\hline \$96T002095 & 142: 7 & Upper $1 / 2$ & $<199$ & $<201$ & $<200$ & & & \\
\hline \$96T002096 & \multirow[t]{2}{*}{ 142: 8} & Upper $1 / 2$ & $<199$ & $<198$ & $<198.5$ & & & \\
\hline S96T002108 & & Lower $1 / 2$ & $<204$ & $<200$ & $<202$ & & & \\
\hline \multicolumn{3}{|c|}{ 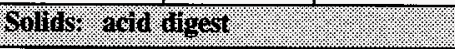 } & 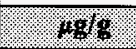 & 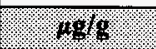 & 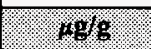 & 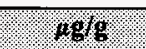 & $\%$ & 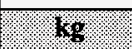 \\
\hline S96T001905 & 138: 2R1 & Lower $1 / 2$ & 11.9 & 11.8 & 11.85 & \multirow[t]{9}{*}{10.9} & \multirow[t]{9}{*}{6.2} & \multirow[t]{9}{*}{28.3} \\
\hline S96T002050 & 138: 6 & Lower $1 / 2$ & 9.6 & 9.99 & 9.795 & & & \\
\hline \$96T002195 & \multirow[t]{2}{*}{ 138: 7} & Upper $1 / 2$ & 9.69 & 9.09 & 9.39 & & & \\
\hline \$96T002203 & & Lower $1 / 2$ & 9.47 & 9.75 & 9.61 & & & \\
\hline S96T002051 & \multirow[t]{2}{*}{ 138: 8} & Upper $1 / 2$ & 9.82 & 9.21 & 9.515 & & & \\
\hline \$96T002052 & & Lower $1 / 2$ & 9.55 & 9.57 & 9.56 & & & \\
\hline S96T002196 & \multirow[t]{2}{*}{$138: 9$} & Upper $1 / 2$ & 10.2 & 10.4 & 10.3 & & & \\
\hline \$96T002200 & & Lower $1 / 2$ & 9.44 & 9.23 & 9.335 & & & \\
\hline S96T002097 & 142: 1 & Upper $1 / 2$ & 12.4 & 12.6 & 12.5 & & & \\
\hline
\end{tabular}


Table A-26. Tank 241-S-101 Analytical Results: Silver. (4 sheets)

\begin{tabular}{|c|c|c|c|c|c|c|c|c|}
\hline $\begin{array}{l}\text { Sample } \\
\text { Nunber }\end{array}$ & $\begin{array}{l}\text { Cort } \\
\text { Segrment }\end{array}$ & 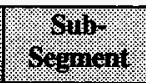 & rerouli: & Dupliate & $\begin{array}{l}\text { Sample } \\
\text { Vern }\end{array}$ & $\begin{array}{l}\text { Oncerall } \\
\text { Mean }\end{array}$ & Mrsin & $\begin{array}{l}\text { profucted } \\
\text { inventory }\end{array}$ \\
\hline \multicolumn{3}{|c|}{ Solfirs ocidg digest } & .1896 & 1.9814. & 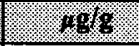 & 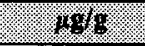 & (2.8. & 16 \\
\hline S96T002312 & \multirow[t]{2}{*}{$142: 2$} & Upper $1 / 2$ & 13.7 & 12 & 12.85 & \multirow[t]{14}{*}{ Cont. } & \multirow[t]{14}{*}{ Cont. } & \multirow[t]{14}{*}{ Cont. } \\
\hline S96T002317 & & Lower $1 / 2$ & 13.9 & 14.1 & 14 & & & \\
\hline S96T002313 & \multirow[t]{2}{*}{$142: 3$} & Upper $1 / 2$ & 9.62 & 8.45 & 9.035 & & & \\
\hline S96T002320 & & Lower $1 / 2$ & 13.4 & 13 & 13.2 & & & \\
\hline S96T002109 & \multirow[t]{2}{*}{$142: 4$} & Upper $1 / 2$ & 14.1 & 14 & 14.05 & & & \\
\hline S96T002110 & & Lower $1 / 2$ & 13.2 & 12.6 & 12.9 & & & \\
\hline S96T002111 & \multirow{2}{*}{$142: 5$} & Upper $1 / 2$ & 10.1 & 9.82 & 9.96 & & & \\
\hline S96T002112 & & Lower $1 / 2$ & 9.33 & 9.55 & 9.44 & & & \\
\hline S96T002113 & \multirow[t]{2}{*}{$142: 6$} & Upper $1 / 2$ & 13.5 & 15.2 & 14.35 & & & \\
\hline S96T002098 & & Lower $1 / 2$ & 8.92 & 14.8 & $11.86^{\mathrm{QC}: \mathrm{e}}$ & & & \\
\hline S96T002114 & \multirow[t]{2}{*}{$142: 7$} & Upper $1 / 2$ & 9.83 & 9.67 & 9.75 & & & \\
\hline S96T002115 & & Lower $1 / 2$ & 9.72 & 9.59 & 9.655 & & & \\
\hline S96T002116 & \multirow{2}{*}{$142: 8$} & Upper $1 / 2$ & 10.5 & 9.44 & 9.97 & & & \\
\hline S96T002117 & & Lower $1 / 2$ & 9.84 & 9.28 & 9.56 & & & \\
\hline \multicolumn{3}{|c|}{ Solfol comporites: faston oligert: } & 19.9/9 & 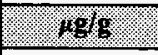 & 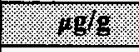 & 1.996 & 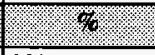 & kg: \\
\hline S96T002723 & 138 & N/A & $<209$ & $<217$ & $<213$ & \multirow[t]{2}{*}{$<210$} & \multirow[t]{2}{*}{ N/A } & \multirow[t]{2}{*}{$<544$} \\
\hline S96T002731 & 142 & N/A & $<204$ & $<210$ & $<207$ & & & \\
\hline \multicolumn{3}{|c|}{ Solid composites: actid digest: } & $1.49 / \mathrm{g}$ & 1898 & ogrg & 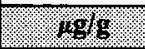 & 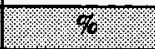 & (2) \\
\hline S96T002724 & 138 & N/A & $<6.86$ & $<6.82$ & $<6.84$ & \multirow[t]{2}{*}{$<6.76$} & \multirow[t]{2}{*}{ N/A } & \multirow[t]{2}{*}{$<17.5$} \\
\hline S96T002733 & 142 & N/A & 7.02 & $<6.35$ & 6.685 & & & \\
\hline
\end{tabular}




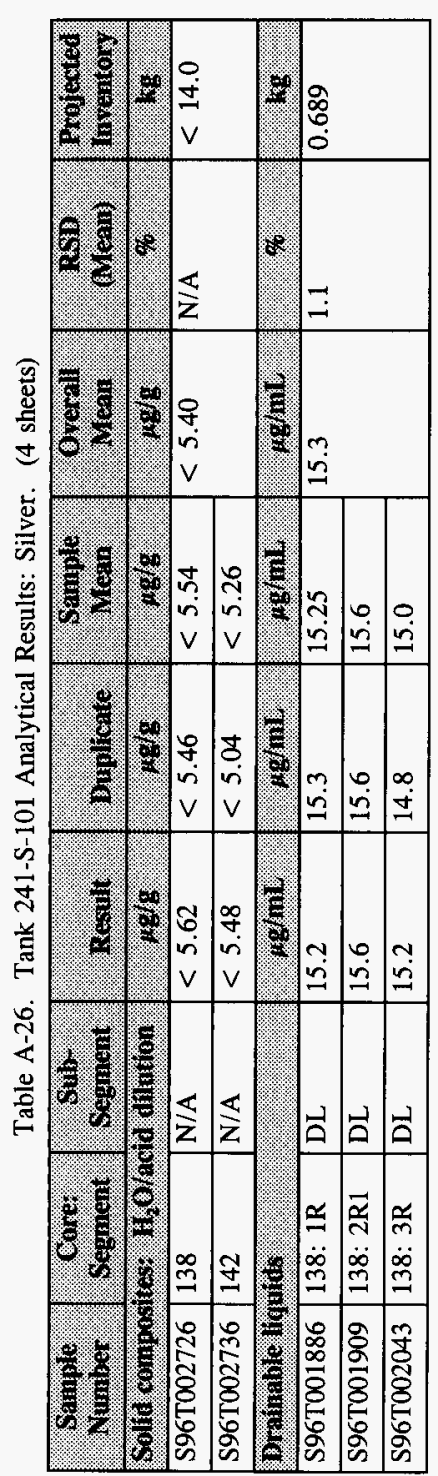


Table A-27. Tank 241-S-101 Analytical Results: Sodium. (4 sheets)

\begin{tabular}{|c|c|c|c|c|c|c|c|c|}
\hline Womuo & ogment & 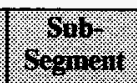 & (1) & Buplin:16 & (1) & Whath & 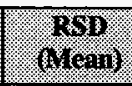 & Mromor \\
\hline \multicolumn{3}{|c|}{ 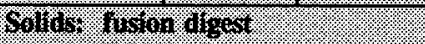 } & 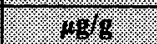 & $68 \%$ & W & 1968 & \% & (3) \\
\hline S96T001903 & 138: 2R1 & Lower $1 / 2$ & $1.480 \mathrm{E}+05$ & $1.760 \mathrm{E}+05$ & $1.620 \mathrm{E}+05$ & $1.49 \mathrm{E}+05$ & 4.8 & $\begin{array}{l}3.86 \mathrm{E}+0 \\
5\end{array}$ \\
\hline S96T002040 & 138: $3 \mathrm{AR}$ & Whole & $1.690 \mathrm{E}+05$ & $1.700 \mathrm{E}+05$ & $1.695 \mathrm{E}+05$ & & & \\
\hline S96T001891 & \multirow[t]{2}{*}{$138: 5$} & Upper $1 / 2$ & $1.500 \mathrm{E}+05$ & $1.510 \mathrm{E}+05$ & $1.505 \mathrm{E}+05$ & & & \\
\hline S96T001902 & & Lower $1 / 2$ & $1.410 \mathrm{E}+05$ & $1.410 \mathrm{E}+05$ & $1.410 \mathrm{E}+05$ & & & \\
\hline S96T002045 & \multirow[t]{2}{*}{ 138: 6} & Upper $1 / 2$ & $1.400 \mathrm{E}+05$ & $1.390 \mathrm{E}+05$ & $1.395 \mathrm{E}+05$ & & & \\
\hline S96T002047 & & Lower $1 / 2$ & $1.090 \mathrm{E}+05$ & $1.380 \mathrm{E}+05$ & $1.235 \mathrm{E}+05^{\mathrm{QC}: \mathrm{e}}$ & & & \\
\hline S96T002193 & \multirow[t]{2}{*}{ 138: 7} & Upper $1 / 2$ & $1.350 \mathrm{E}+05$ & $1.370 \mathrm{E}+05$ & $1.360 \mathrm{E}+05$ & & & \\
\hline S96T002202 & & Lower $1 / 2$ & $1.300 \mathrm{E}+05$ & $1.330 \mathrm{E}+05$ & $1.315 \mathrm{E}+05$ & & & \\
\hline S96T002046 & \multirow[t]{2}{*}{ 138: 8} & Upper $1 / 2$ & $1.290 \mathrm{E}+05$ & $1.280 \mathrm{E}+05$ & $1.285 \mathrm{E}+05$ & & & \\
\hline \$96T002048 & & Lower $1 / 2$ & $1.280 \mathrm{E}+05$ & $1.300 \mathrm{E}+05$ & $1.290 \mathrm{E}+05$ & & & \\
\hline S96T002194 & \multirow[t]{2}{*}{ 138: 9} & Upper $1 / 2$ & $1.150 \mathrm{E}+05$ & $1.160 \mathrm{E}+05$ & $1.155 \mathrm{E}+05$ & & & \\
\hline S96T002199 & & Lower $1 / 2$ & $1.260 \mathrm{E}+05$ & $1.250 \mathrm{E}+05$ & $1.255 \mathrm{E}+05$ & & & \\
\hline$\$ 96 \mathrm{~T} 002090$ & 142: 1 & Upper $1 / 2$ & $1.780 \mathrm{E}+05$ & $1.770 \mathrm{E}+05$ & $1.775 \mathrm{E}+05$ & & & \\
\hline S96T002310 & \multirow[t]{2}{*}{ 142: 2} & Upper $1 / 2$ & $1.790 \mathrm{E}+05$ & $1.740 \mathrm{E}+05$ & $1.765 \mathrm{E}+05$ & & & \\
\hline S96T002316 & & Lower $1 / 2$ & $2.070 \mathrm{E}+05$ & $2.050 \mathrm{E}+05$ & $2.060 \mathrm{E}+05$ & & & \\
\hline S96T002311 & \multirow[t]{2}{*}{$142: 3$} & Upper $1 / 2$ & $1.960 \bar{E}+05$ & $1.960 \mathrm{E}+05$ & $1.960 \mathrm{E}+05$ & & & \\
\hline S96T002319 & & Lower $1 / 2$ & $1.890 \mathrm{E}+05$ & $1.850 \mathrm{E}+05$ & $1.870 \mathrm{E}+05$ & & & \\
\hline \$96T002092 & \multirow[t]{2}{*}{$142: 4$} & Upper $1 / 2$ & $1.960 \mathrm{E}+05$ & $1.960 \mathrm{E}+05$ & $1.960 \mathrm{E}+05$ & & & \\
\hline S96T002105 & & Lower $1 / 2$ & $1.600 \mathrm{E}+05$ & $1.620 \mathrm{E}+05$ & $1.610 \mathrm{E}+05$ & & & \\
\hline
\end{tabular}


Table A-27. Tank 241-S-101 Analytical Results: Sodium. (4 sheets)

\begin{tabular}{|c|c|c|c|c|c|c|c|c|}
\hline Womigl & ochor & 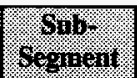 & m & ouplearts & 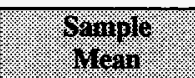 & $\begin{array}{l}\text { Orefill } \\
\text { Wean }\end{array}$ & 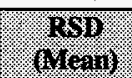 & Frosfords \\
\hline \multicolumn{3}{|c|}{ 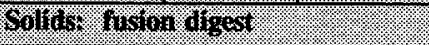 } & 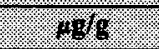 & 4.68 & 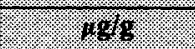 & $4 \%$ & 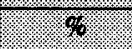 & 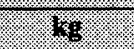 \\
\hline S96T002093 & \multirow[t]{2}{*}{$142: 5$} & Upper $1 / 2$ & $1.390 \mathrm{E}+05$ & $1.380 \mathrm{E}+05$ & $1.385 \mathrm{E}+05$ & & & \\
\hline S96T002106 & & Lower $1 / 2$ & $1.490 \mathrm{E}+05$ & $1.270 \mathrm{E}+\overline{05}$ & $1.380 \mathrm{E}+05$ & & & \\
\hline S96T002095 & \multirow[t]{2}{*}{$142: 7$} & Upper $1 / 2$ & $1.220 \mathrm{E}+05$ & $1.250 \mathrm{E}+05$ & $1.235 \mathrm{E}+05$ & \multirow{4}{*}{ Cont. } & \multirow{4}{*}{ Cont. } & \multirow{4}{*}{ Cont. } \\
\hline \$96T002107 & & Lower $1 / 2$ & 92,500 & $1.270 \mathrm{E}+05$ & $1.098 \mathrm{E}+05^{\mathrm{QC}: e}$ & & & \\
\hline S96T002096 & \multirow[t]{2}{*}{$142: 8$} & Upper $1 / 2$ & $1.220 \mathrm{E}+05$ & $1.220 \mathrm{E}+05$ & $1.220 \mathrm{E}+05$ & & & \\
\hline S96T002108 & & Lower $1 / 2$ & $1.300 \mathrm{E}+05$ & $1.240 \mathrm{E}+05$ & $1.270 \mathrm{E}+05$ & & & \\
\hline S96T001892 & \multirow[t]{2}{*}{ 138: 5} & Upper $1 / 2$ & $1.380 \mathrm{E}+05$ & $1.460 \mathrm{E}+05$ & $1.420 \mathrm{E}+05$ & & & \\
\hline S96T001904 & & Lower $1 / 2$ & $1.370 \mathrm{E}+05$ & $1.500 \mathrm{E}+05$ & $1.435 \mathrm{E}+05$ & & & \\
\hline S96T002049 & \multirow[t]{2}{*}{ 138: 6} & Upper $1 / 2$ & $1.220 \mathrm{E}+05$ & $1.210 \mathrm{E}+05$ & $1.215 \mathrm{E}+05$ & & & \\
\hline S96T002050 & & Lower $1 / 2$ & $1.230 \mathrm{E}+05$ & $1.230 \mathrm{E}+05$ & $1.230 \mathrm{E}+05$ & & & \\
\hline S96T002195 & \multirow[t]{2}{*}{ 138: 7} & Upper $1 / 2$ & $1.150 \mathrm{E}+05$ & $1.160 \mathrm{E}+05$ & $1.155 \mathrm{E}+05$ & & & \\
\hline \$96T002203 & & Lower $1 / 2$ & $1.080 \mathrm{E}+05$ & $1.160 \overline{\mathrm{E}}+05$ & $1.120 \mathrm{E}+05$ & & & \\
\hline S96T002051 & \multirow[t]{2}{*}{ 138: 8} & Upper $1 / 2$ & $1.100 \mathrm{E}+05$ & $1.090 \mathrm{E}+05$ & $1.095 \mathrm{E}+05$ & & & \\
\hline S96T002052 & & Lower $1 / 2$ & $1.090 \mathrm{E}+05$ & $1.070 \mathrm{E}+05$ & $1.080 \mathrm{E}+05$ & & & \\
\hline S96T002196 & 138: 9 & Upper $1 / 2$ & $1.020 \mathrm{E}+05$ & $1.000 \mathrm{E}+05$ & $1.010 \mathrm{E}+05$ & & & \\
\hline
\end{tabular}


Table A-27. Tank 241-S-101 Analytical Results: Sodium. (4 sheets)

\begin{tabular}{|c|c|c|c|c|c|c|c|c|}
\hline 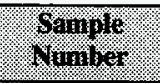 & oconert & 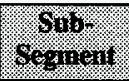 & 3isinll & Buplital & 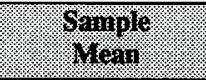 & How & 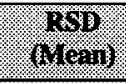 & Wrolestad \\
\hline \multicolumn{3}{|c|}{ 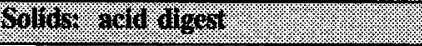 } & 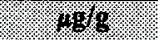 & 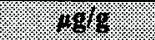 & 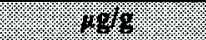 & $19 \%$ & 60 & 48 \\
\hline S96T002097 & 142: 1 & Upper $1 / 2$ & $1.570 \mathrm{E}+05$ & $1.550 \mathrm{E}+05$ & $1.560 \mathrm{E}+05$ & & & \\
\hline S96T002312 & \multirow[t]{2}{*}{$142: 2$} & Upper $1 / 2$ & $1.680 \mathrm{E}+05$ & $1.460 \mathrm{E}+05$ & $1.5 \overline{70 \mathrm{E}+05}$ & & & \\
\hline S96T002317 & & Lower $1 / 2$ & $1.720 \mathrm{E}+05$ & $1.710 \mathrm{E}+05$ & $1.715 \mathrm{E}+05$ & & & \\
\hline S96T002313 & \multirow[t]{2}{*}{$142: 3$} & Upper $1 / 2$ & $1.200 \mathrm{E}+05$ & $1.050 \mathrm{E}+05$ & $1.125 \mathrm{E}+05$ & \multirow[t]{12}{*}{ Cont. } & \multirow[t]{12}{*}{ Cont. } & \multirow[t]{12}{*}{ Cont. } \\
\hline S96T002320 & & Lower $1 / 2$ & $1.620 \mathrm{E}+05$ & $1.610 \mathrm{E}+05$ & $1.615 \mathrm{E}+05$ & & & \\
\hline \$96T002109 & \multirow[t]{2}{*}{ 142: 4} & Upper $1 / 2$ & $1.690 \mathrm{E}+05$ & $1.690 \mathrm{E}+05$ & $1.690 \mathrm{E}+05$ & & & \\
\hline S96T002110 & & Lower $1 / 2$ & $1.400 \mathrm{E}+05$ & $1.400 \mathrm{E}+05$ & $1.400 \mathrm{E}+05$ & & & \\
\hline S96T002111 & \multirow[t]{2}{*}{$142: 5$} & Upper $1 / 2$ & $1.280 \mathrm{E}+05$ & $1.260 \mathrm{E}+05$ & $1.270 \mathrm{E}+05$ & & & \\
\hline S96T002112 & & Lower $1 / 2$ & $1.160 \mathrm{E}+05$ & $1.140 \mathrm{E}+05$ & $1.150 \mathrm{E}+05$ & & & \\
\hline S96T002113 & \multirow[t]{2}{*}{$142: 6$} & Upper $1 / 2$ & $1.550 \mathrm{E}+05$ & $1.820 \mathrm{E}+05$ & $1.685 \mathrm{E}+05$ & & & \\
\hline S96T002098 & & Lower $1 / 2$ & $1.120 \mathrm{E}+05$ & $1.750 \mathrm{E}+05$ & $1.435 \mathrm{E}+05^{\mathrm{QC}: \mathrm{d}, \mathrm{e}}$ & & & \\
\hline \$96T002114 & \multirow[t]{2}{*}{$142: 7$} & Upper $1 / 2$ & $1.170 \mathrm{E}+05$ & $1 . \overline{170 \mathrm{E}+05}$ & $1.170 \mathrm{E}+05$ & & & \\
\hline S96T002115 & & Lower $1 / 2$ & $1.110 \mathrm{E}+05$ & $1.090 \mathrm{E}+05$ & $1.100 \mathrm{E}+05$ & & & \\
\hline S96T002116 & \multirow[t]{2}{*}{$142: 8$} & Upper $1 / 2$ & $1.080 \mathrm{E}+05$ & $1.050 \mathrm{E}+05$ & $1.065 \mathrm{E}+05$ & & & \\
\hline S96T002117 & & Lower $1 / 2$ & $1.160 \mathrm{E}+05$ & $1.130 \mathrm{E}+05$ & $1.145 \mathrm{E}+05$ & & & \\
\hline \multicolumn{3}{|c|}{ 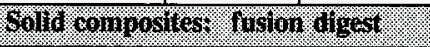 } & $.10 \%$ & $.834 \%$ & 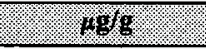 & 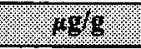 & $6 \%$ & 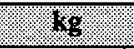 \\
\hline S96T002723 & 138 & N/A & $1.620 \mathrm{E}+05$ & $1.870 \mathrm{E}+05$ & $1.745 \mathrm{E}+05$ & $1.91 \mathrm{E}+05$ & 8.6 & $\begin{array}{l}4.95 E+0 \\
5\end{array}$ \\
\hline S96T002731 & 142 & N/A & $2.090 \mathrm{E}+05$ & $2.060 \mathrm{E}+05$ & $2.075 \mathrm{E}+05$ & & & \\
\hline
\end{tabular}


Table A-27. Tank 241-S-101 Analytical Results: Sodium. (4 sheets)

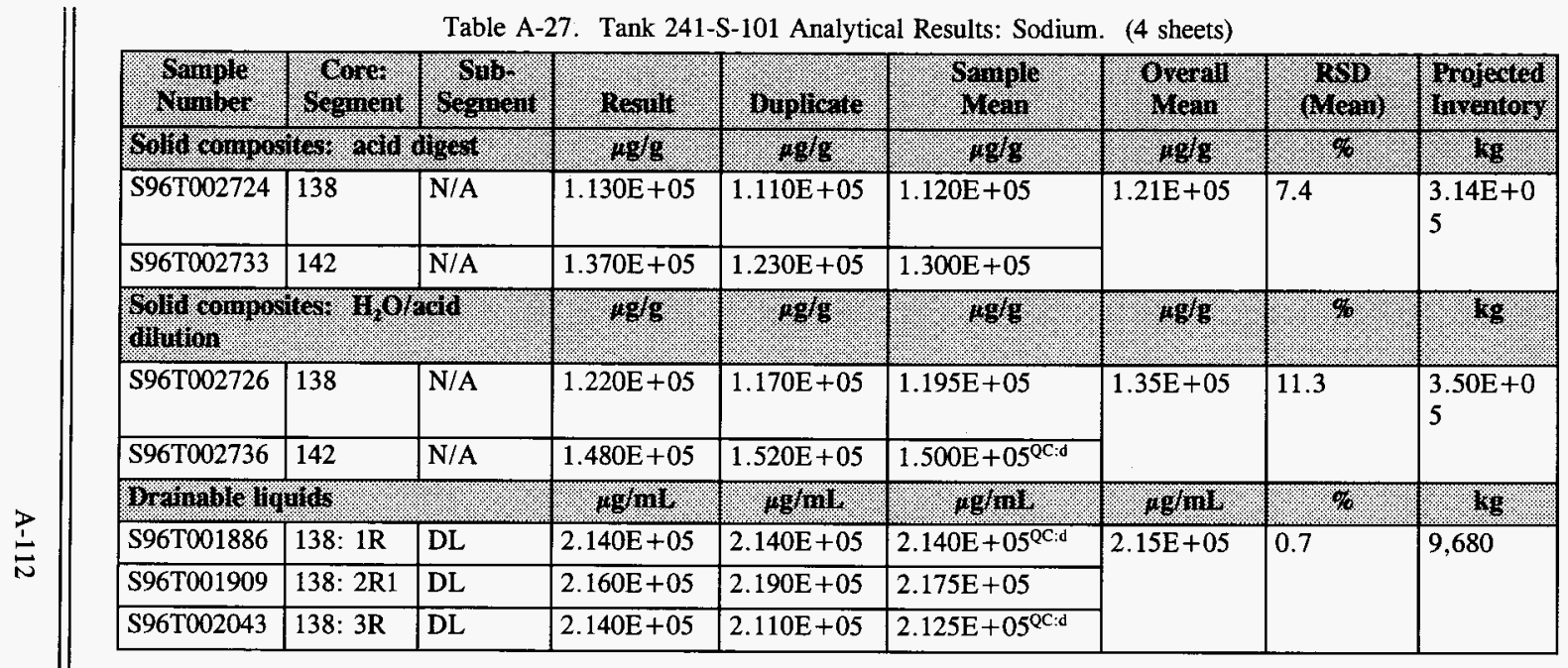


Table A-28. Tank 241-S-101 Analytical Results: Strontium. (4 sheets)

\begin{tabular}{|c|c|c|c|c|c|c|c|c|}
\hline Whingle & Sorment. & o.811301\% & kitil & 9411806 & Ma111\% & \%or & $\begin{array}{l}198 \\
(1)\end{array}$ & 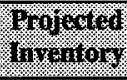 \\
\hline \multicolumn{3}{|c|}{ 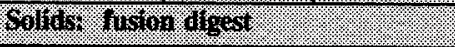 } & 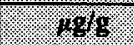 & 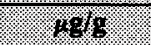 & $96 \%$ & $1 \% 8$ & 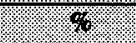 & 46 \\
\hline S96T001903 & 138: 2R1 & Lower $1 / 2$ & $<197$ & $<186$ & $<191.5$ & \multirow[t]{21}{*}{292} & \multirow[t]{21}{*}{10.9} & \multirow[t]{21}{*}{757} \\
\hline S96T002040 & 138: $3 \mathrm{AR}$ & Whole & $<204$ & $<191$ & $<197.5$ & & & \\
\hline S96T001891 & \multirow[t]{2}{*}{$138: 5$} & Upper $1 / 2$ & $<210$ & $<212$ & $<211$ & & & \\
\hline S96T001902 & & Lower $1 / 2$ & 216 & 219 & 217.5 & & & \\
\hline S96T002045 & \multirow[t]{2}{*}{ 138: 6} & Upper $1 / 2$ & 235 & 228 & 231.5 & & & \\
\hline S96T002047 & & Lower $1 / 2$ & 234 & 291 & $262.5^{Q \mathrm{QC}: \mathrm{e}}$ & & & \\
\hline S96T002193 & \multirow[t]{2}{*}{ 138: 7} & Upper $1 / 2$ & 319 & 325 & 322 & & & \\
\hline \$96T002202 & & Lower $1 / 2$ & 390 & 384 & 387 & & & \\
\hline S96T002046 & \multirow[t]{2}{*}{ 138: 8} & Upper $1 / 2$ & 415 & 418 & 416.5 & & & \\
\hline S96T002048 & & Lower $1 / 2$ & 478 & 479 & 478.5 & & & \\
\hline S96T002194 & \multirow[t]{2}{*}{$138: 9$} & Upper $1 / 2$ & 585 & 573 & 579 & & & \\
\hline S96T002199 & & Lower $1 / 2$ & 255 & 216 & 235.5 & & & \\
\hline S96T002090 & 142: 1 & Upper $1 / 2$ & $<206$ & $<205$ & $<205.5$ & & & \\
\hline S96T002310 & \multirow[t]{2}{*}{ 142: 2} & Upper $1 / 2$ & $<188$ & $<185$ & $<186.5$ & & & \\
\hline S96T002316 & & Lower $1 / 2$ & $<204$ & $<203$ & $<203.5$ & & & \\
\hline S96T002311 & \multirow[t]{2}{*}{$142: 3$} & Upper $1 / 2$ & $<202$ & $<206$ & $<204$ & & & \\
\hline \$96T002319 & & Lower $1 / 2$ & $<\overline{195}$ & $<191$ & $<193$ & & & \\
\hline S96T002092 & \multirow[t]{2}{*}{$142: 4$} & Upper $1 / 2$ & $<202$ & $<200$ & $<201$ & & & \\
\hline S96T002105 & & Lower $1 / 2$ & $<200$ & $<206$ & $<203$ & & & \\
\hline S96T002093 & \multirow[t]{2}{*}{ 142: 5} & Upper $1 / 2$ & $<194$ & $<187$ & $<190.5$ & & & \\
\hline S96T002106 & & Lower $1 / 2$ & 264 & 216 & 240 & & & \\
\hline
\end{tabular}




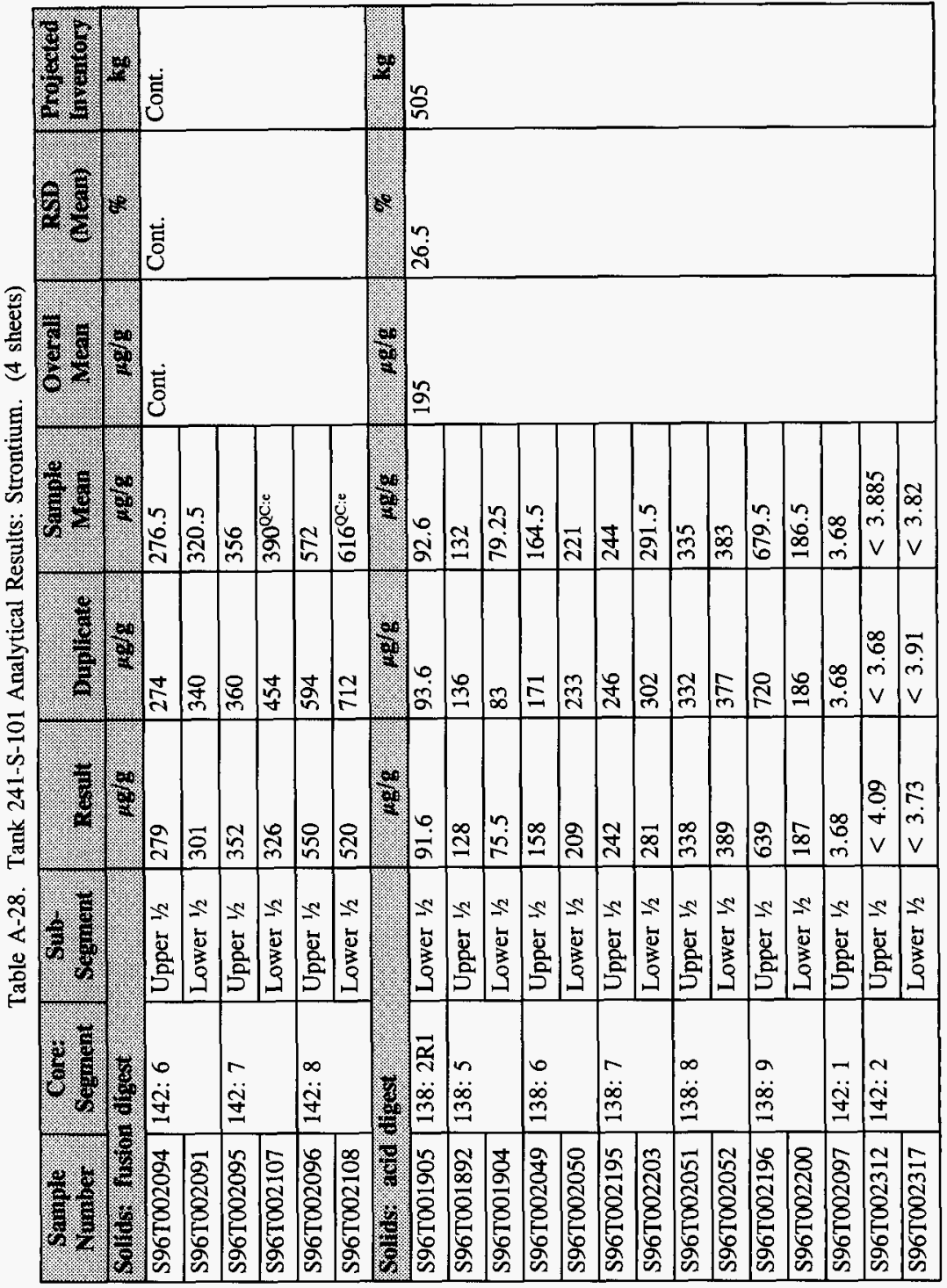


Table A-28. Tank 241-S-101 Analytical Results: Strontium. (4 sheets)

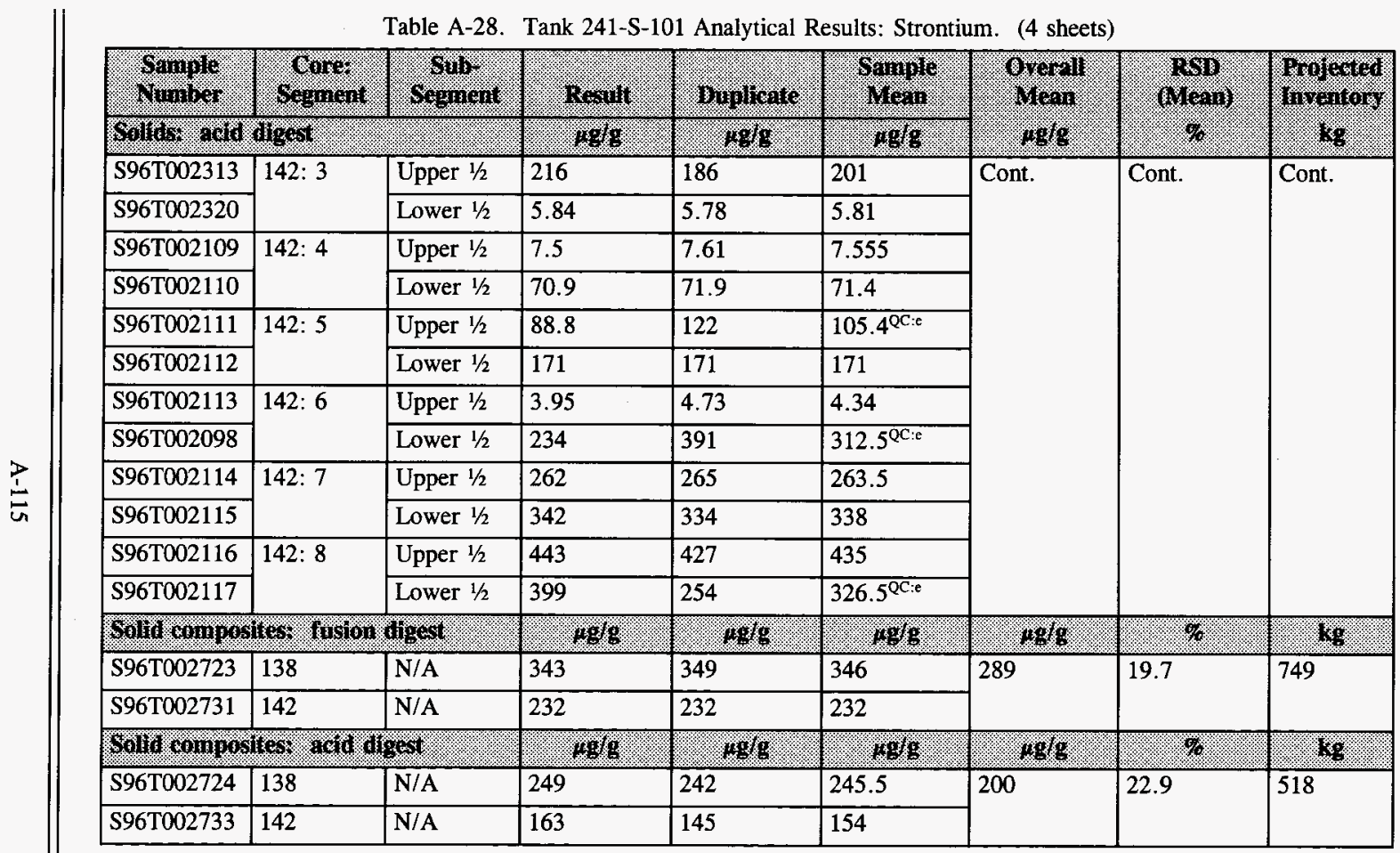


Table A-28. Tank 241-S-101 Analytical Results: Strontium. (4 sheets)

\begin{tabular}{|c|c|c|c|c|c|c|c|c|}
\hline $\begin{array}{l}\text { Sample } \\
\text { Number }\end{array}$ & $\begin{array}{l}\text { Corre: } \\
\text { Segmen }\end{array}$ & $\begin{array}{l}\text { Suib: } \\
\text { Segrnent }\end{array}$ & Rerall & Minuleate & $\begin{array}{l}\text { Sorriple } \\
\text { Mrent }\end{array}$ & Ororall & (16) & $\begin{array}{l}\text { Drougter } \\
\text { Inventor }\end{array}$ \\
\hline Sollog ogmpo & $\mathrm{Ees}^{2} \cdot 1 \%$ & W"WHion & gerg & 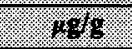 & 808 & 1888 & (8) & lig \\
\hline S96T002726 & 138 & N/A & $<5.62$ & $<5.46$ & $<5.54$ & \multirow[t]{2}{*}{$<5.40$} & \multirow[t]{2}{*}{ N/A } & \multirow[t]{2}{*}{$<14.0$} \\
\hline S96T002736 & 142 & N/A & $<5.48$ & $<5.04$ & $<5.26$ & & & \\
\hline \multicolumn{3}{|c|}{ Dratnable Enows } & $18 / 10$ & OEg & ag/mis: & $18 \%$ & $\%$ & kis. \\
\hline S96T001886 & 138: 1R & DL & $<4.01$ & $<4.01$ & $<4.01$ & \multirow[t]{3}{*}{$<4.01$} & \multirow[t]{3}{*}{ N/A } & \multirow[t]{3}{*}{$<0.180$} \\
\hline S96T001909 & 138: $2 \mathrm{R} 1$ & $\mathrm{DL}$ & $<4.01$ & $<4.01$ & $<4.01$ & & & \\
\hline S96T002043 & 138: 3R & $\overline{\mathrm{DL}}$ & $<4.01$ & $<4.01$ & $<4.01$ & & & \\
\hline
\end{tabular}


WHC-SD-WM-ER-613 Rev. 0

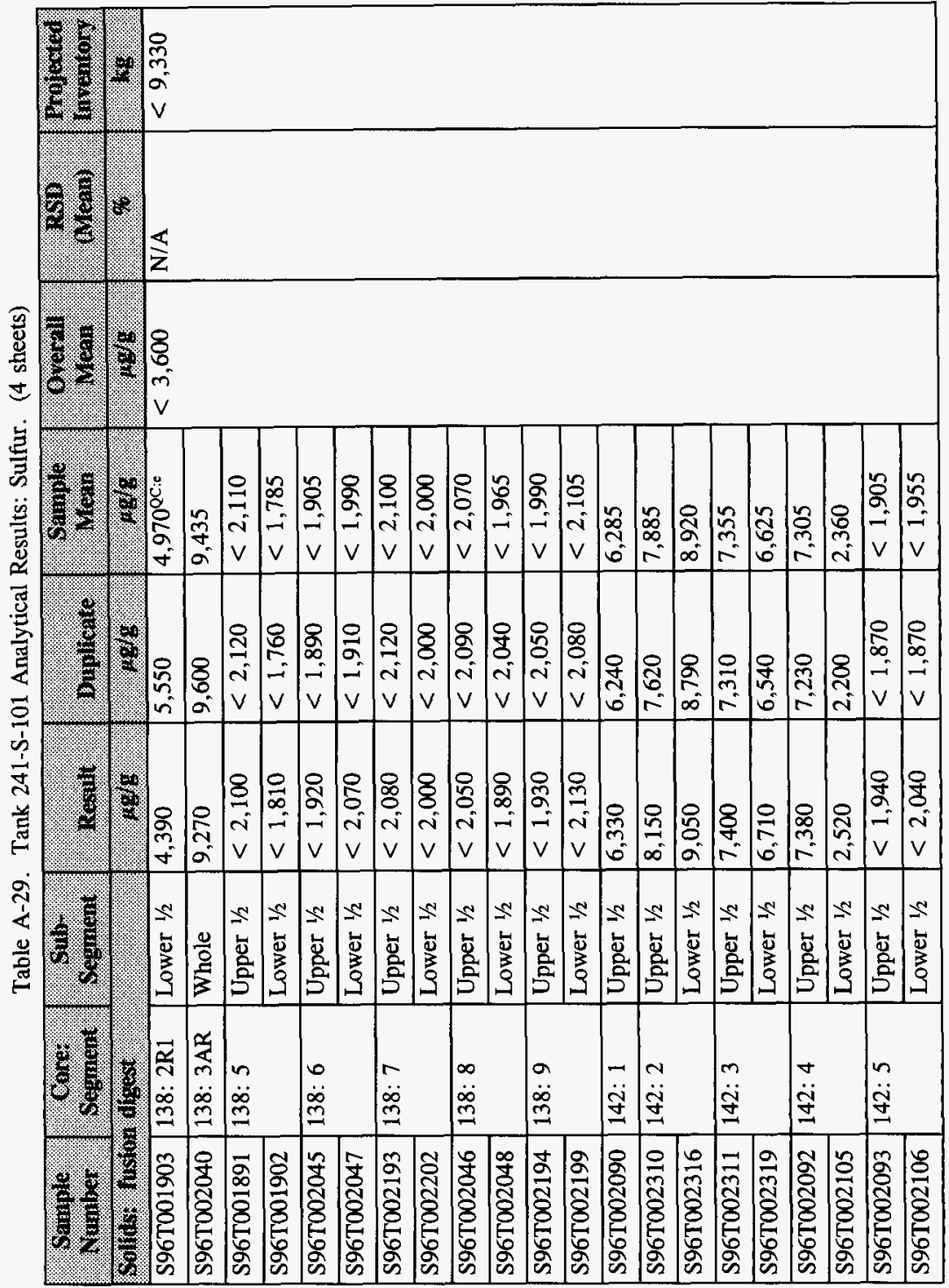


WHC-SD-WM-ER-613 Rev. 0

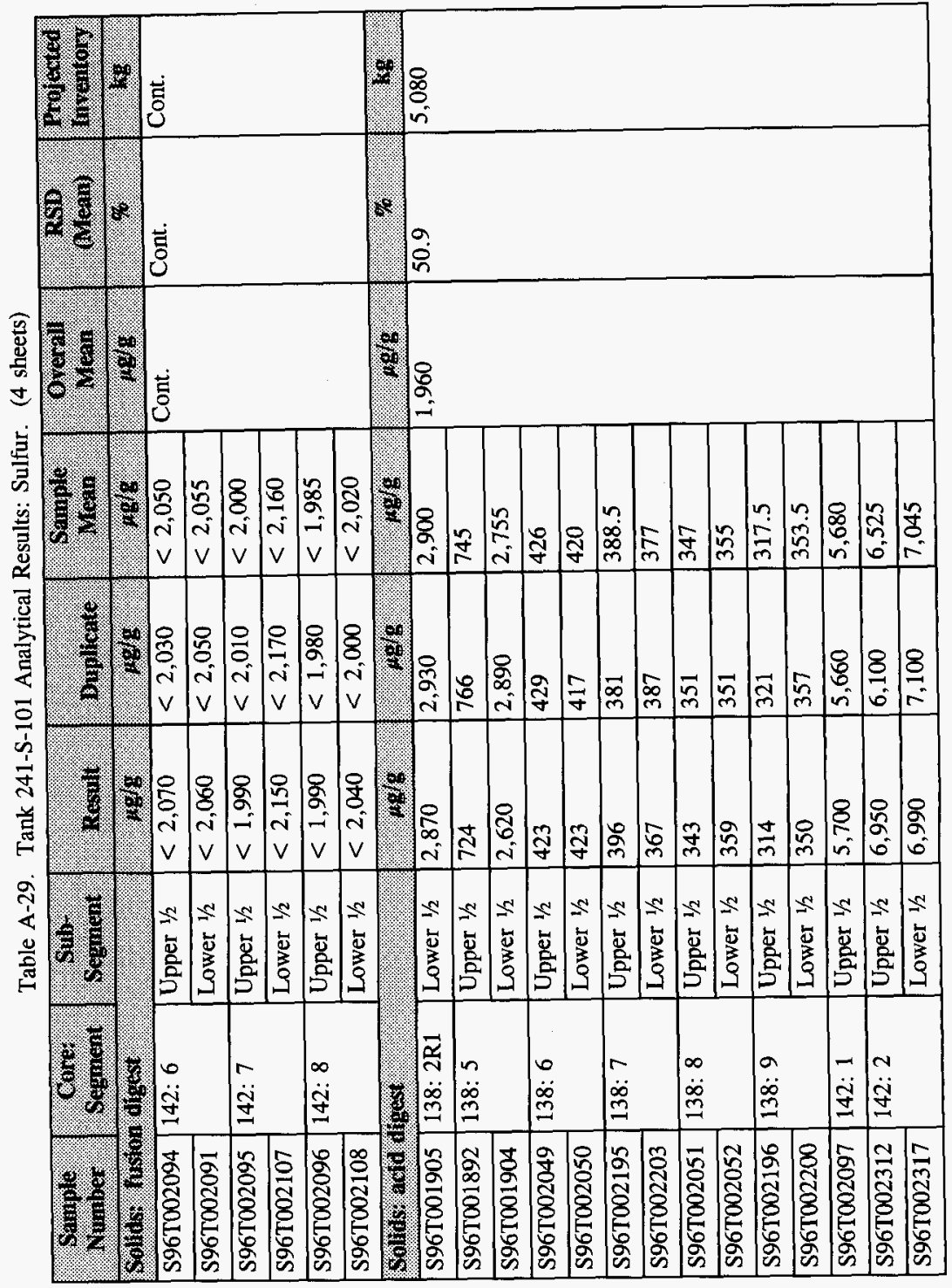


Table A-29. Tank 241-S-101 Analytical Results: Sulfur. (4 sheets)

\begin{tabular}{|c|c|c|c|c|c|c|c|c|}
\hline Monilot & sopnest & otonents & revili & Hinilkats & 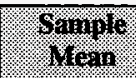 & $4 \%$ & 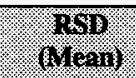 & Pros coffol \\
\hline \multicolumn{3}{|c|}{ 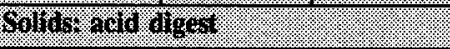 } & 1018 & $181 \mathrm{~s}$ & (196\% & .0968 & 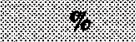 & 4.98 \\
\hline S96T002313 & \multirow[t]{2}{*}{$142: 3$} & Upper $1 / 2$ & 396 & 328 & 362 & \multirow[t]{12}{*}{ Cont. } & \multirow[t]{12}{*}{ Cont. } & \multirow[t]{12}{*}{ Cont. } \\
\hline S96T002320 & & Lower $1 / 2$ & 5,450 & 5,450 & 5,450 & & & \\
\hline S96T002109 & \multirow[t]{2}{*}{ 142: 4} & Upper $1 / 2$ & 6,580 & 6,270 & 6,425 & & & \\
\hline S96T002110 & & Lower $1 / 2$ & 2,050 & 2,120 & 2,085 & & & \\
\hline S96T002111 & \multirow[t]{2}{*}{$142: 5$} & Upper $1 / 2$ & 452 & 423 & 437.5 & & & \\
\hline S96T002112 & & Lower $1 / 2$ & 365 & 358 & 361.5 & & & \\
\hline S96T002113 & \multirow[t]{2}{*}{$142: 6$} & Upper $1 / 2$ & 5,900 & 7,110 & 6,505 & & & \\
\hline S96T002098 & & Lower $1 / 2$ & 356 & 566 & $461^{\mathrm{QC}: \mathrm{e}}$ & & & \\
\hline S96T002114 & \multirow[t]{2}{*}{$142: 7$} & Upper $1 / 2$ & 345 & 348 & 346.5 & & & \\
\hline S96T002115 & & Lower $1 / 2$ & 347 & 330 & 338.5 & & & \\
\hline S96T002116 & \multirow[t]{2}{*}{$142: 8$} & Upper $1 / 2$ & 328 & 319 & 323.5 & & & \\
\hline S96T002117 & & Lower $1 / 2$ & 356 & 362 & 359 & & & \\
\hline \multicolumn{3}{|c|}{ 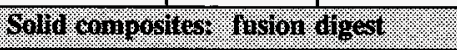 } & 496 & 496 & $4 \%$ & $148 / 8$ & Win. & 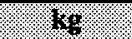 \\
\hline S96T002723 & 138 & N/A & $<2,090$ & $<2,170$ & $<2,130$ & \multirow[t]{2}{*}{2,530} & \multirow[t]{2}{*}{15.8} & \multirow[t]{2}{*}{6,560} \\
\hline S96T002731 & 142 & N/A & 2,890 & 2,970 & 2,930 & & & \\
\hline \multicolumn{3}{|c|}{ 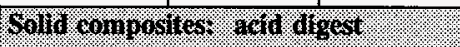 } & 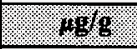 & 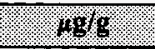 & 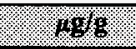 & $6 g$ & \%. & . \\
\hline S96T002724 & 138 & $\mathrm{~N} /$ & 437 & 431 & 434 & \multirow[t]{2}{*}{1,610} & \multirow[t]{2}{*}{73.1} & \multirow[t]{2}{*}{4,170} \\
\hline S96T002733 & 142 & N/A & 2,940 & 2,650 & 2,795 & & & \\
\hline
\end{tabular}


Table A-29. Tank 241-S-101 Analytical Results: Sulfur. (4 sheets)

\begin{tabular}{|c|c|c|c|c|c|c|c|c|}
\hline Woringer & Whor & Womert & Perill & Orulloate & Whan & Worll & 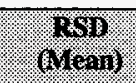 & Mrougros \\
\hline \multicolumn{3}{|c|}{ 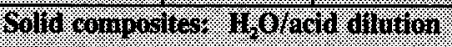 } & 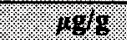 & $1 \% 8$ & tols & $14 \%$ & $8 \%$ & 68 \\
\hline \$96T002726 & 138 & N/A & 452 & 412 & 432 & \multirow[t]{2}{*}{1,650} & \multirow[t]{2}{*}{73.8} & \multirow[t]{2}{*}{4,280} \\
\hline S96T002736 & 142 & N/A & 3,120 & 2,610 & 2,865 & & & \\
\hline \multicolumn{3}{|c|}{ 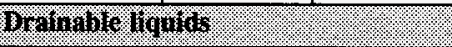 } & $48 \%$ & HWH & 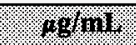 & $160 \% \mathrm{~m}$ & $\%$ & 69 \\
\hline S96T001886 & 138: 1R & DL & 1,720 & 1,720 & 1,720 & \multirow[t]{3}{*}{1,860} & \multirow[t]{3}{*}{5.1} & \multirow[t]{3}{*}{83.7} \\
\hline S96T001909 & 138: 2R1 & $\overline{\mathrm{DL}}$ & 1,820 & 1,830 & 1,825 & & & \\
\hline S96T002043 & 138: $3 \mathrm{R}$ & $\overline{D L}$ & 2,060 & 2,020 & 2,040 & & & \\
\hline
\end{tabular}




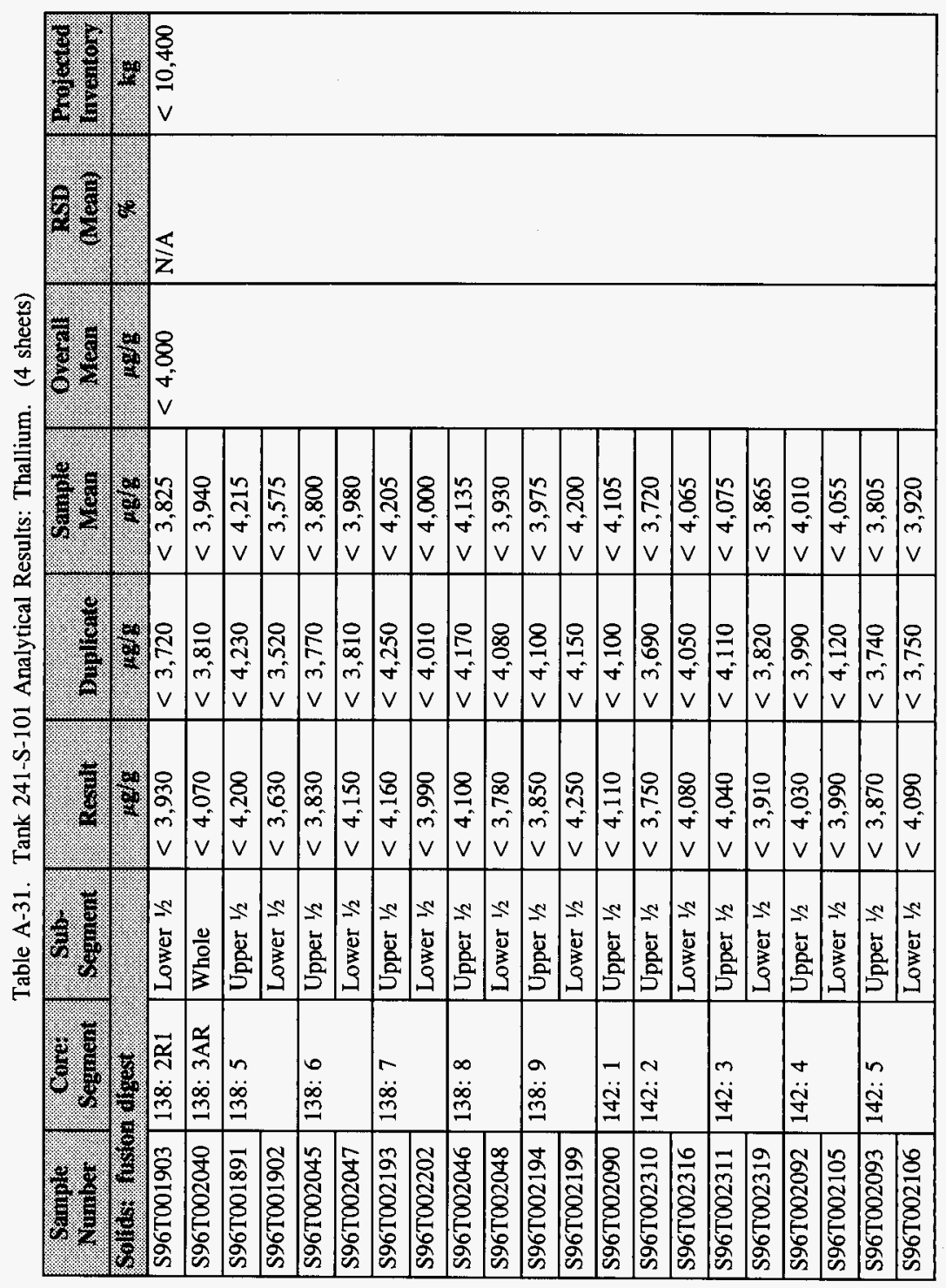


Table A-31. Tank 241-S-101 Analytical Results: Thallium. (4 sheets)

\begin{tabular}{|c|c|c|c|c|c|c|c|c|}
\hline 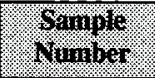 & $\%$ \%omer & sompat & Reasiliti & Mulligate & . Mrong & Whapli & 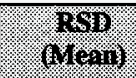 & moloted \\
\hline \multicolumn{2}{|c|}{ 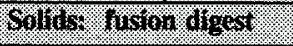 } & 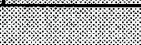 & 1498 & $148 \% 9$ & 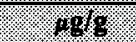 & 168 & $1: \%: \%$ & 18 \\
\hline S96T002094 & \multirow[t]{2}{*}{$142: 6$} & Upper $1 / 2$ & $<4,150$ & $<4,050$ & $<4,100$ & \multirow[t]{6}{*}{ Cont. } & \multirow[t]{6}{*}{ Cont. } & \multirow[t]{6}{*}{ Cont. } \\
\hline S96T002091 & & Lower $1 / 2$ & $<4,120$ & $<4,090$ & $<4,105$ & & & \\
\hline S96T002095 & \multirow[t]{2}{*}{ 142: 7} & Upper $1 / 2$ & $<3,970$ & $<4,0,0$ & $<3,990$ & & & \\
\hline S96T002107 & & Lower $1 / 2$ & $<4,290$ & $<4,350$ & $<4,320$ & & & \\
\hline S96T002096 & \multirow[t]{2}{*}{$142: 8$} & Upper $1 / 2$ & $<3,980$ & $<3,970$ & $<3,975$ & & & \\
\hline S96T002108 & & Lower $1 / 2$ & $<4,080$ & $<3,990$ & $<4,035$ & & & \\
\hline \multicolumn{3}{|c|}{ Sollits adid afrest: } & 1.96 & 1.48 & 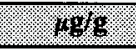 & 1486 & 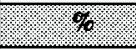 & . \\
\hline S96T001905 & 138: 2R1 & Lower $1 / 2$ & $<76.2$ & $<77.5$ & $<76.85$ & \multirow[t]{14}{*}{$<77.5$} & \multirow[t]{14}{*}{ N/A } & \multirow[t]{14}{*}{$<200$} \\
\hline S96T001892 & \multirow[t]{2}{*}{$138: 5$} & Upper $1 / 2$ & $<76.4$ & $<80.5$ & $<78.45$ & & & \\
\hline S96T001904 & & Lower $1 / 2$ & $<71.6$ & $<78.4$ & $<75$ & & & \\
\hline S96T002049 & \multirow[t]{2}{*}{ 138: 6} & Upper $1 / 2$ & $<75.3$ & $<77.9$ & $<76.6$ & & & \\
\hline S96T002050 & & Lower $1 / 2$ & $<74.2$ & $<81.8$ & $<78$ & & & \\
\hline S96T002195 & \multirow[t]{2}{*}{$138: 7$} & Upper $1 / 2$ & $<88$ & $<89.8$ & $<88.9$ & & & \\
\hline \$96T002203 & & Lower $1 / 2$ & $<78.2$ & $<81.5$ & $<79.85$ & & & \\
\hline S96T002051 & \multirow[t]{2}{*}{ 138: 8} & Upper $1 / 2$ & $<73.9$ & $<76$ & $<74.95$ & & & \\
\hline \$96T002052 & & Lower $1 / 2$ & $<75.8$ & $<78.2$ & $<77$ & & & \\
\hline S96T002196 & \multirow[t]{2}{*}{ 138: 9} & Upper $1 / 2$ & $<73.8$ & $<72.8$ & $<73.3$ & & & \\
\hline S96T002200 & & Lower $1 / 2$ & $<73.6$ & $<79.6$ & $<76.6$ & & & \\
\hline S96T002097 & 142: 1 & Upper $1 / 2$ & $<71.5$ & $<71.5$ & $<71.5$ & & & \\
\hline S96T002312 & \multirow[t]{2}{*}{ 142: 2} & Upper $1 / 2$ & $<81.9$ & $<\overline{73.6}$ & $<77.75$ & & & \\
\hline \$96T002317 & & Lower $1 / 2$ & $<74.6$ & $<78.1$ & $<76.35$ & & & \\
\hline
\end{tabular}


Table A-31. Tank 241-S-101 Analytical Results: Thallium. (4 sheets)

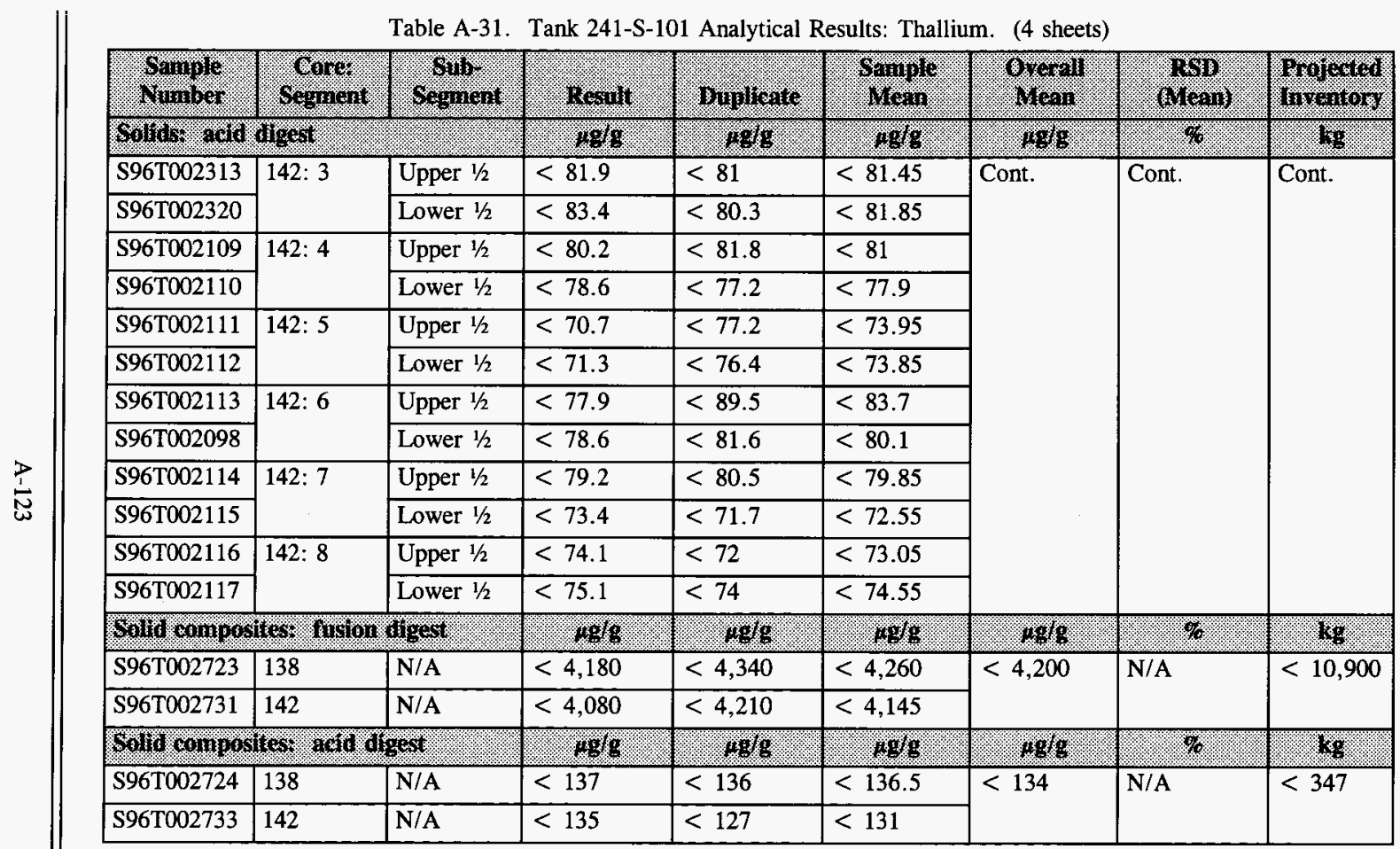


Table A-31. Tank 241-S-101 Analytical Results: Thallium. (4 sheets)

\begin{tabular}{|c|c|c|c|c|c|c|c|c|}
\hline Woning & Sogment & $\begin{array}{l}\text { Surt } \\
\text { Segment }\end{array}$ & resill & Brolugate & Waresura & $W_{1 / 811}$ & 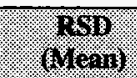 & misedrot \\
\hline \multicolumn{3}{|c|}{ 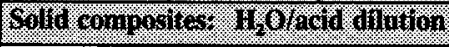 } & 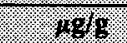 & 180 & 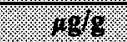 & 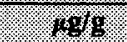 & 4 & 13 \\
\hline S96T002726 & 138 & N/A & $<112$ & $<109$ & $<110.5$ & \multirow[t]{2}{*}{$<108$} & \multirow[t]{2}{*}{ N/A } & \multirow[t]{2}{*}{$<280$} \\
\hline S96T002736 & 142 & N/A & $<110$ & $<101$ & $<105.5$ & & & \\
\hline \multicolumn{3}{|c|}{ Bromablo 19 unds. } & Hinl & 104111 & $461 \% 11$ & $1 \% \% 111$ & \% & 18 \\
\hline S96T001886 & 138: 1R & DL & $<80.2$ & $<80.2$ & $<80.2$ & \multirow[t]{3}{*}{$<80.2$} & \multirow[t]{3}{*}{ N/A } & \multirow[t]{3}{*}{$<3.61$} \\
\hline S96T001909 & 138: 2R1 & $\mathrm{DL}$ & $<80.2$ & $<80.2$ & $<80.2$ & & & \\
\hline S96T002043 & 138: $3 \mathrm{R}$ & DL & $<80.2$ & $<80.2$ & $<80.2$ & & & \\
\hline
\end{tabular}


Table A-32. Tank 241-S-101 Analytical Results: Titanium. (4 sheets)

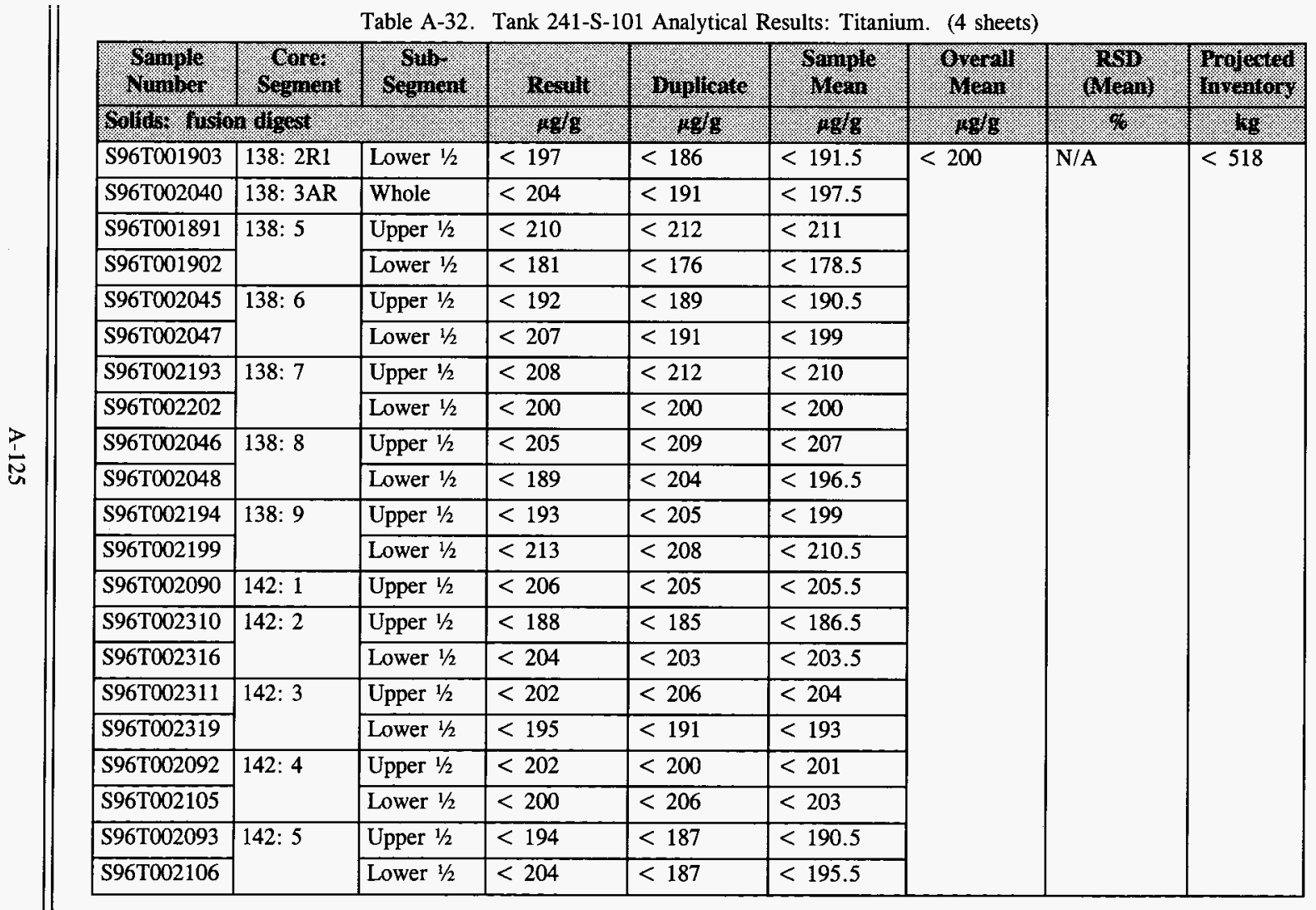




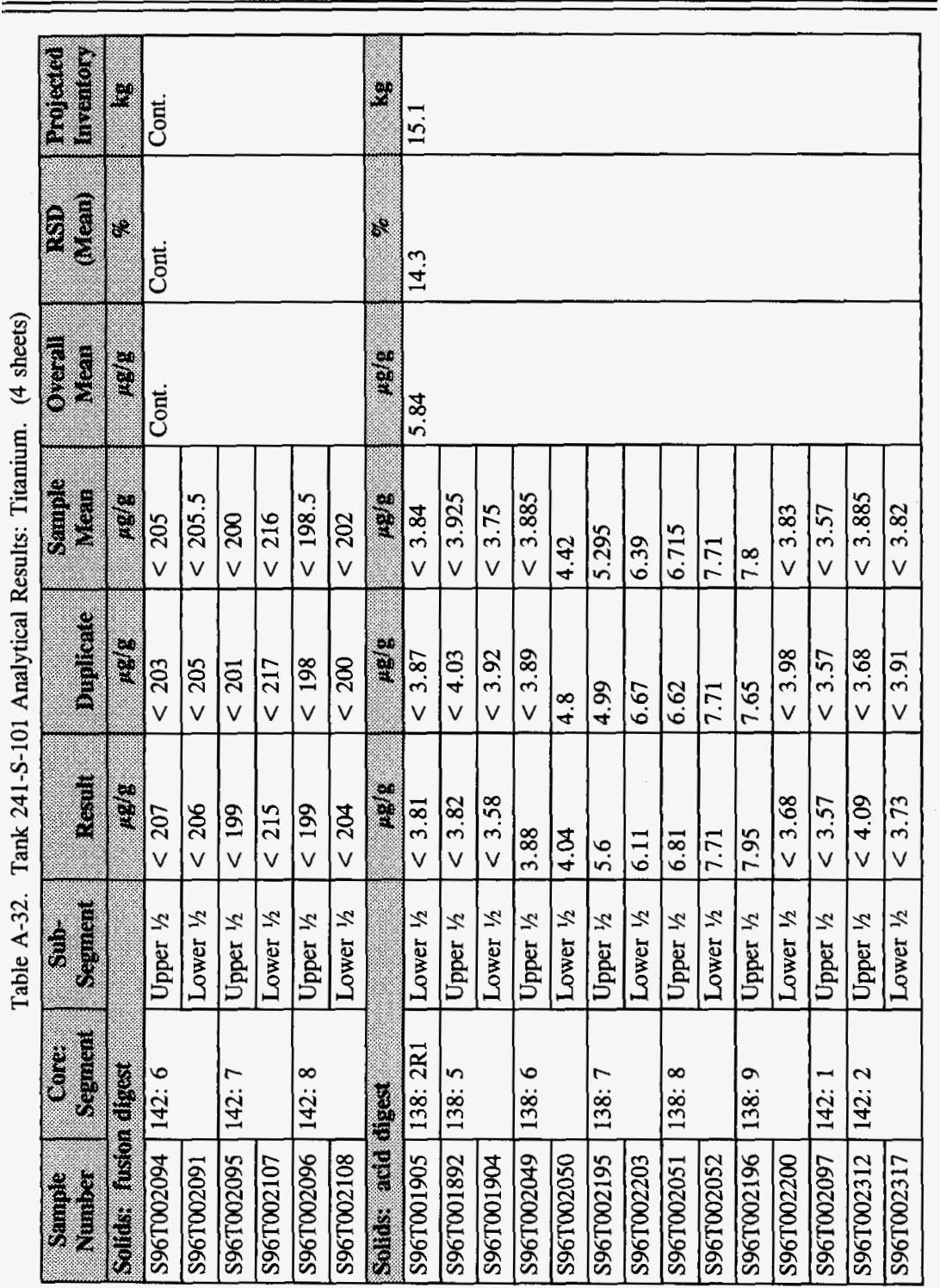


Table A-32. Tank 241-S-101 Analytical Results: Titanium. (4 sheets)

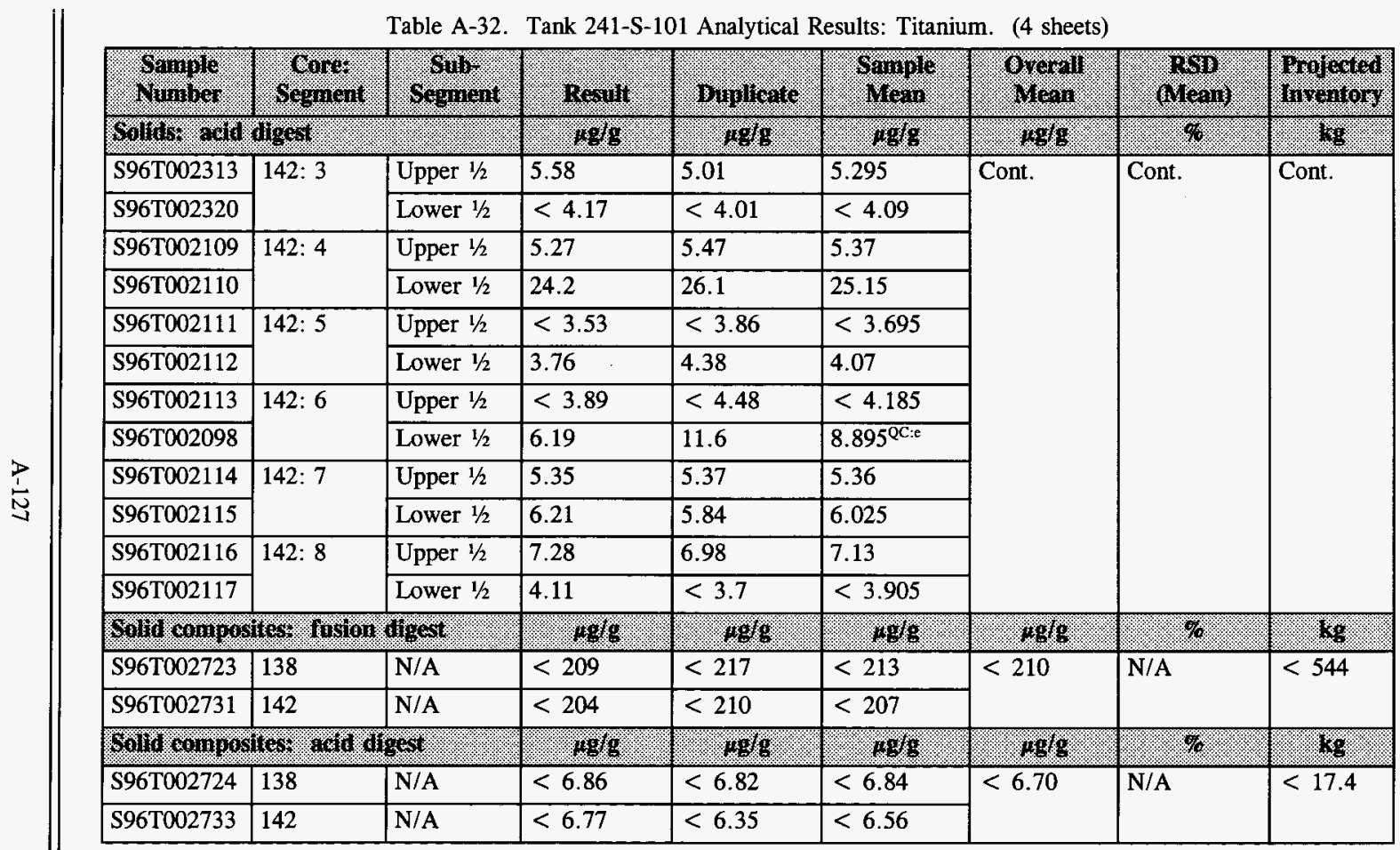


Table A-32. Tank 241-S-101 Analytical Results: Titanium. (4 sheets)

\begin{tabular}{|c|c|c|c|c|c|c|c|c|}
\hline Timibor & \%or & \% & Rerial & Hiplicale & Wound & $\begin{array}{l}\text { Orenul } \\
\text { Mrani: }\end{array}$ & (6) & Wouged \\
\hline \multicolumn{3}{|c|}{ 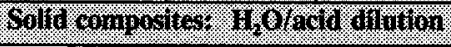 } & 1898 & $18 \%$ & 896 & $140 \%$ & 6. & 49. \\
\hline S96T002726 & 138 & $\mathrm{~N} / \mathrm{A}$ & $<5.62$ & $<5.46$ & $<5.54$ & \multirow[t]{2}{*}{$<5.40$} & \multirow[t]{2}{*}{ N/A } & \multirow[t]{2}{*}{$<14.0$} \\
\hline S96T002736 & 142 & N/A & $<5.48$ & $<5.04$ & $<5.26$ & & & \\
\hline \multicolumn{3}{|c|}{ 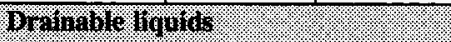 } & 198101 & 101119 & $8,8,111$ & $148 / 111$ & \% & the \\
\hline S96T001886 & 138: 1R & DL & $<4.01$ & $<4.01$ & $<4.01$ & \multirow[t]{3}{*}{$<4.01$} & \multirow[t]{3}{*}{ N/A } & \multirow[t]{3}{*}{$<0.180$} \\
\hline S96T001909 & 138: 2R1 & DL & $<4.01$ & $<4.01$ & $<4.01$ & & & \\
\hline S96T002043 & 138: $3 \mathrm{R}$ & $\mathrm{DL}$ & $<4.01$ & $<4.01$ & $<4.01$ & & & \\
\hline
\end{tabular}


Table A-33. Tank 241-S-101 Analytical Results: Uranium. (4 sheets)

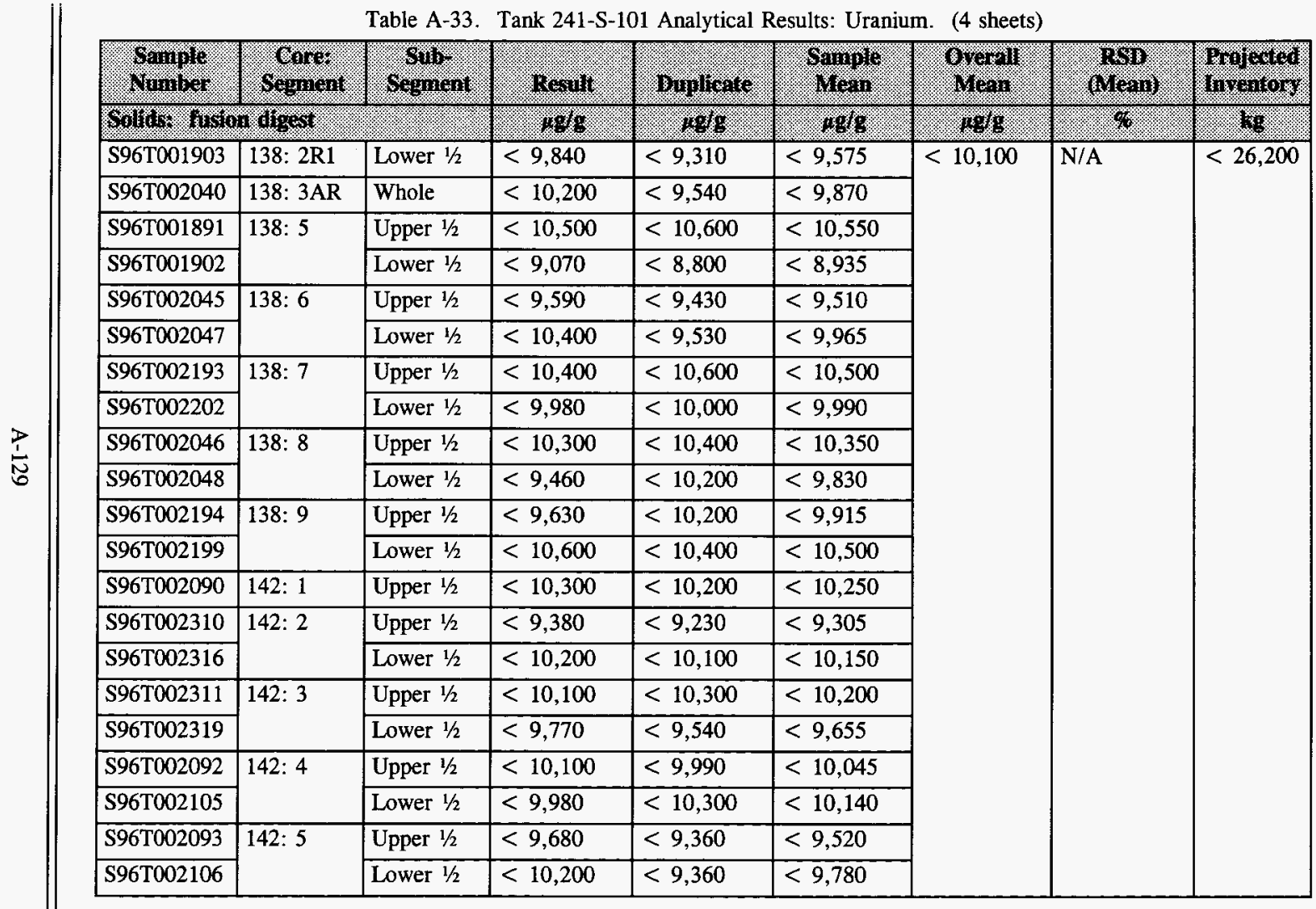




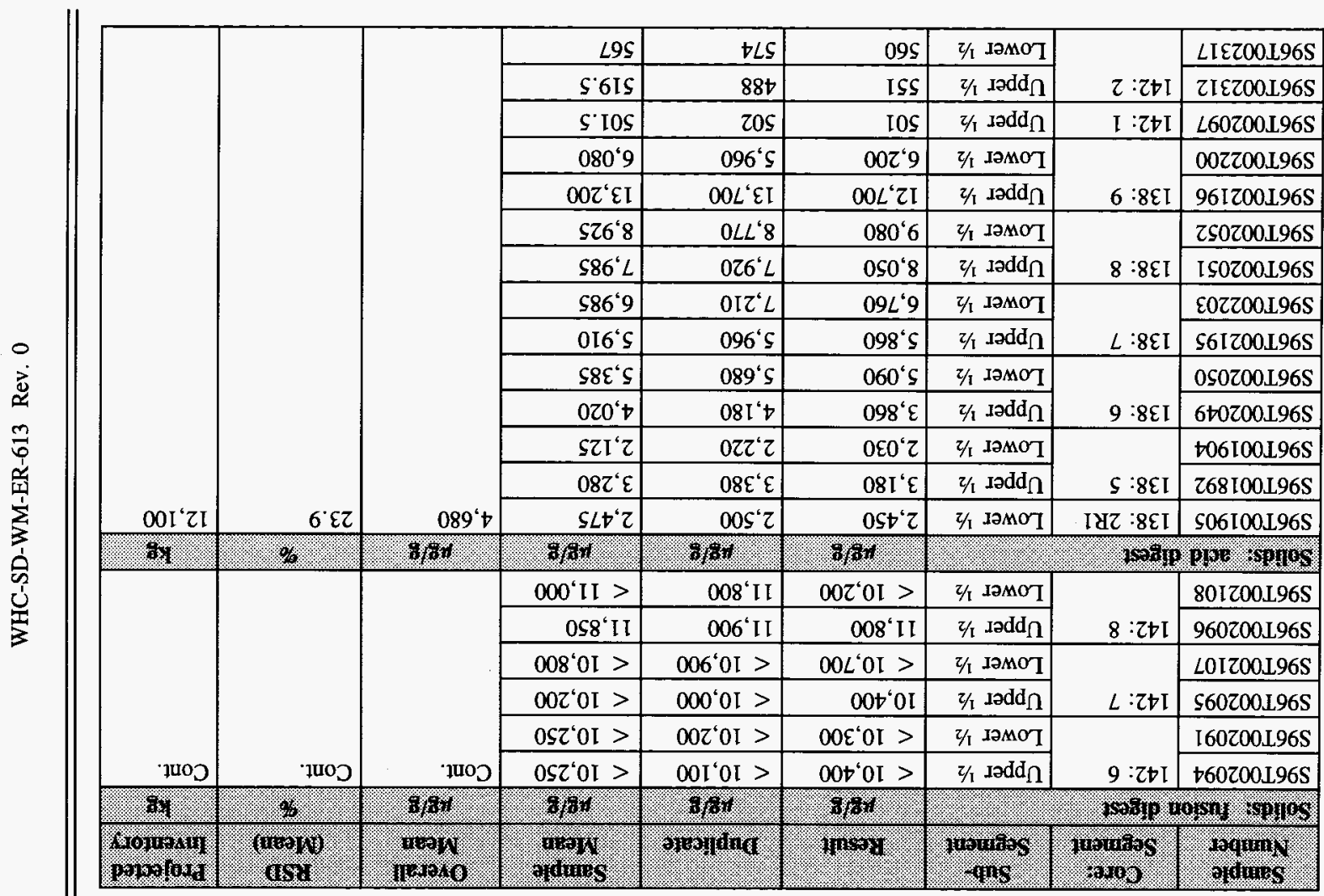

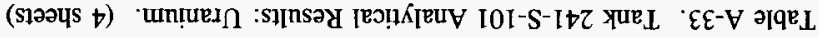


Table A-33. Tank 241-S-101 Analytical Results: Uranium. (4 sheets)

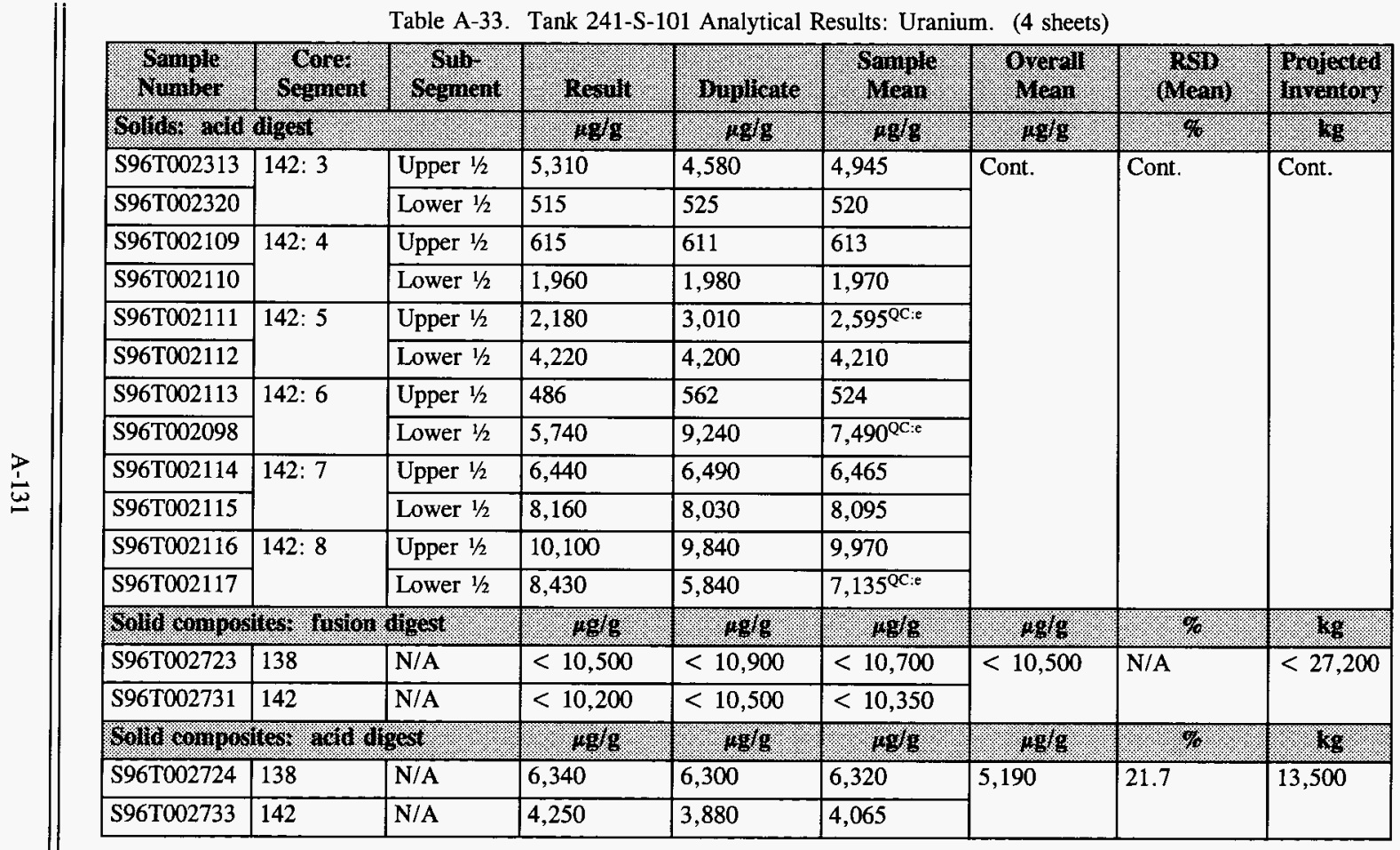


Table A-33. Tank 241-S-101 Analytical Results: Uranium. (4 sheets)

\begin{tabular}{|c|c|c|c|c|c|c|c|c|}
\hline Wonots & 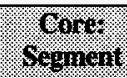 & oging & Rerill & Bullisate & oingen & Gropll & 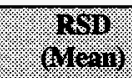 & Hojugrod \\
\hline \multicolumn{3}{|c|}{ 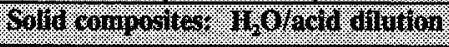 } & 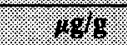 & 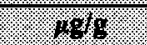 & 6898 & 16086 & 28 & 68 \\
\hline S96T002726 & 138 & N/A & $<281$ & $<273$ & $<277$ & \multirow[t]{2}{*}{$<270$} & \multirow[t]{2}{*}{ N/A } & \multirow[t]{2}{*}{$<700$} \\
\hline S96T002736 & 142 & N/A & $<274$ & $<252$ & $<263$ & & & \\
\hline \multicolumn{3}{|c|}{ 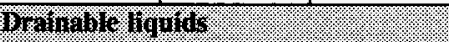 } & 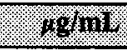 & 48.191. & 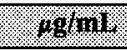 & 6.4010 & $18 \%$ & (1) \\
\hline S96T001886 & 138: $1 \mathrm{R}$ & $\mathrm{DL}$ & $<200$ & $<200$ & $<200$ & \multirow[t]{3}{*}{$<200$} & \multirow[t]{3}{*}{ N/A } & \multirow[t]{3}{*}{$<9.00$} \\
\hline S96T001909 & 138: 2R1 & $\overline{\mathrm{DL}}$ & $<200$ & $<200$ & $<200$ & & & \\
\hline S96T002043 & 138: $3 \mathrm{R}$ & DL & $<200$ & $<200$ & $<200$ & & & \\
\hline
\end{tabular}


Table A-34. Tank 241-S-101 Analytical Results: Uranium (Laser Phosphorescence).

\begin{tabular}{|c|c|c|c|c|c|c|c|c|}
\hline Somple & $\begin{array}{l}\text { Corrt } \\
\text { sevnent }\end{array}$ & $\begin{array}{c}\text { Sull } \\
\text { Sefment }\end{array}$ & Result & Baplicate & $\begin{array}{l}\text { Sample } \\
\text { Wrean }\end{array}$ & $\begin{array}{l}\text { Ororill } \\
\text { Vean }\end{array}$ & $\begin{array}{c}\text { RSO } \\
\text { (Mean) }\end{array}$ & $\begin{array}{l}\text { Projectuld } \\
\text { mirentory }\end{array}$ \\
\hline \multicolumn{3}{|c|}{ Solit composites } & 1889 & 1898 & 1096 & 148 & 8 & 1.98 \\
\hline S96T002723 & 138 & $\mathrm{~N} / \mathrm{A}$ & 8,210 & 7,680 & 7,945 & \multirow[t]{2}{*}{6,370} & \multirow[t]{2}{*}{24.8} & \multirow[t]{2}{*}{16,500} \\
\hline S96T002731 & 142 & N/A & 4,790 & 4,780 & 4,785 & & & \\
\hline
\end{tabular}


Table A-35. Tank 241-S-101 Analytical Results: Vanadium. (4 sheets)

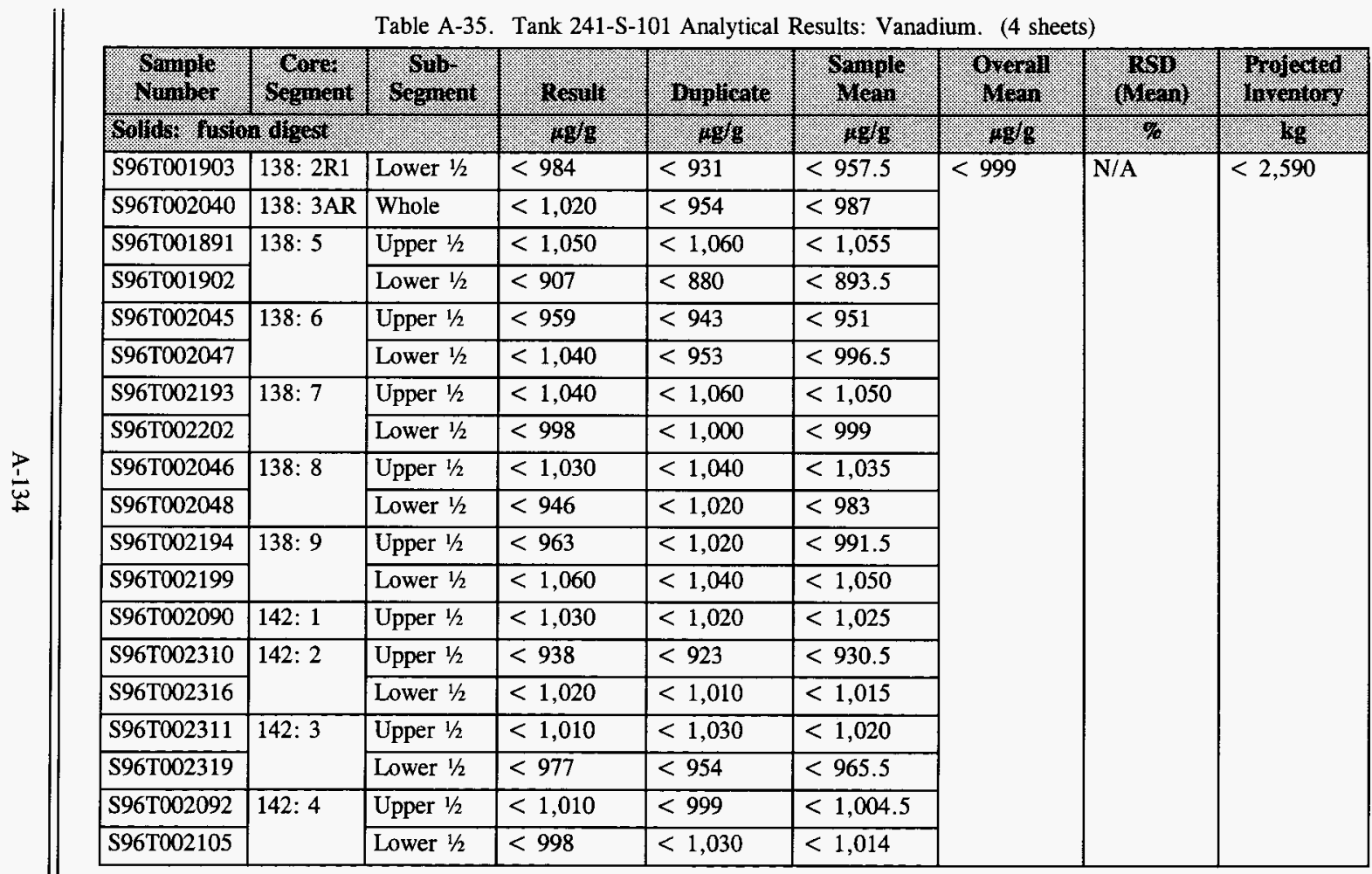


WHC-SD-WM-ER-613 Rev. 0

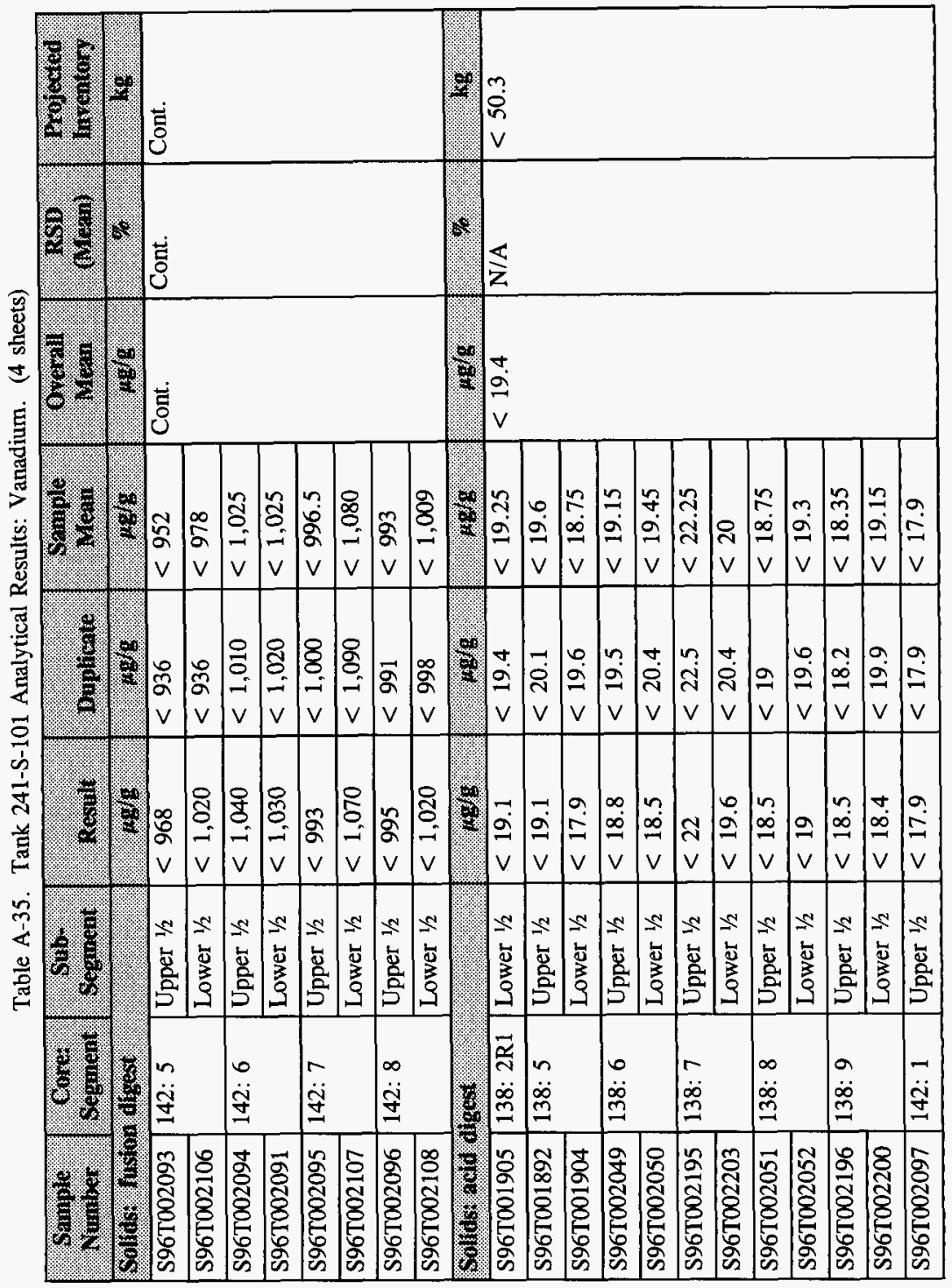


Table A-35. Tank 241-S-101 Analytical Results: Vanadium. (4 sheets)

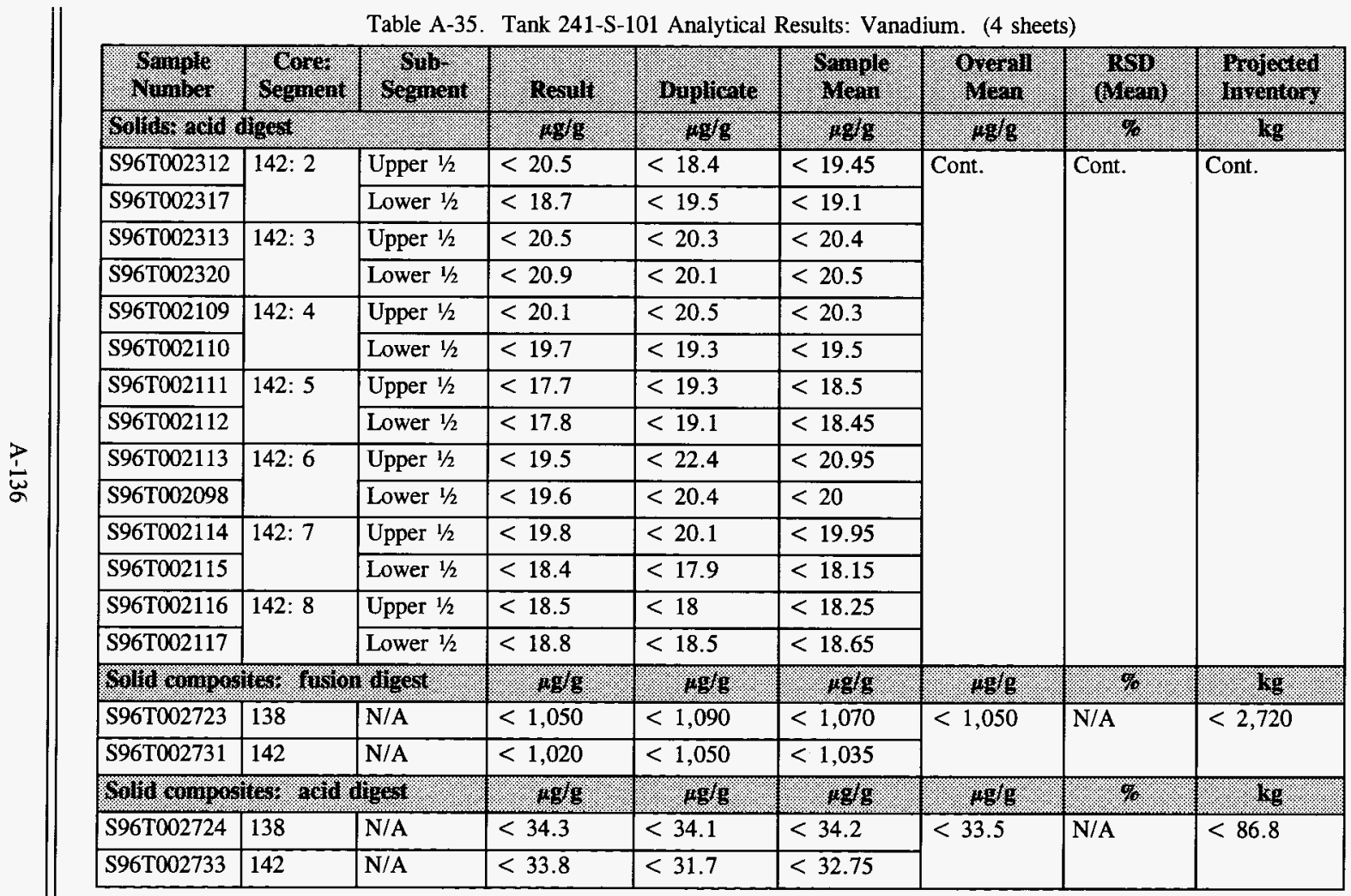


Table A-35. Tank 241-S-101 Analytical Results: Vanadium. (4 sheets)

\begin{tabular}{|c|c|c|c|c|c|c|c|c|}
\hline Wingor & ogonisin & 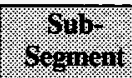 & resill. & Buplicale & Whing & Whall & osion & 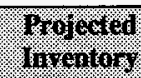 \\
\hline \multicolumn{3}{|c|}{ 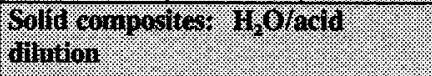 } & 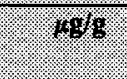 & 498 & $48 / 8$ & 1996 & \% & 46. \\
\hline S96T002726 & 138 & N/A & $<28.1$ & $<27.3$ & $<27.7$ & \multirow[t]{2}{*}{$<27.0$} & \multirow[t]{2}{*}{ N/A } & \multirow[t]{2}{*}{$<70.0$} \\
\hline S96T002736 & 142 & N/A & $<27.4$ & $<25.2$ & $<26.3$ & & & \\
\hline \multicolumn{3}{|c|}{ 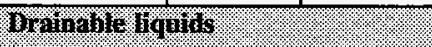 } & 1.8/ & 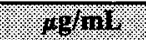 & oggrine & I. & $\%$ & \% \\
\hline S96T001886 & 138: $1 \mathrm{R}$ & DL & $<20.1$ & $<20.1$ & $<20.1$ & \multirow[t]{3}{*}{$<20.1$} & \multirow[t]{3}{*}{ N/A } & \multirow[t]{3}{*}{$<0.905$} \\
\hline S96T001909 & 138: 2R1 & DL & $<20.1$ & $<20.1$ & $<20.1$ & & & \\
\hline S96T002043 & 138: $3 \mathrm{R}$ & $\overline{D L}$ & $<20.1$ & $<20.1$ & $<20.1$ & & & \\
\hline
\end{tabular}




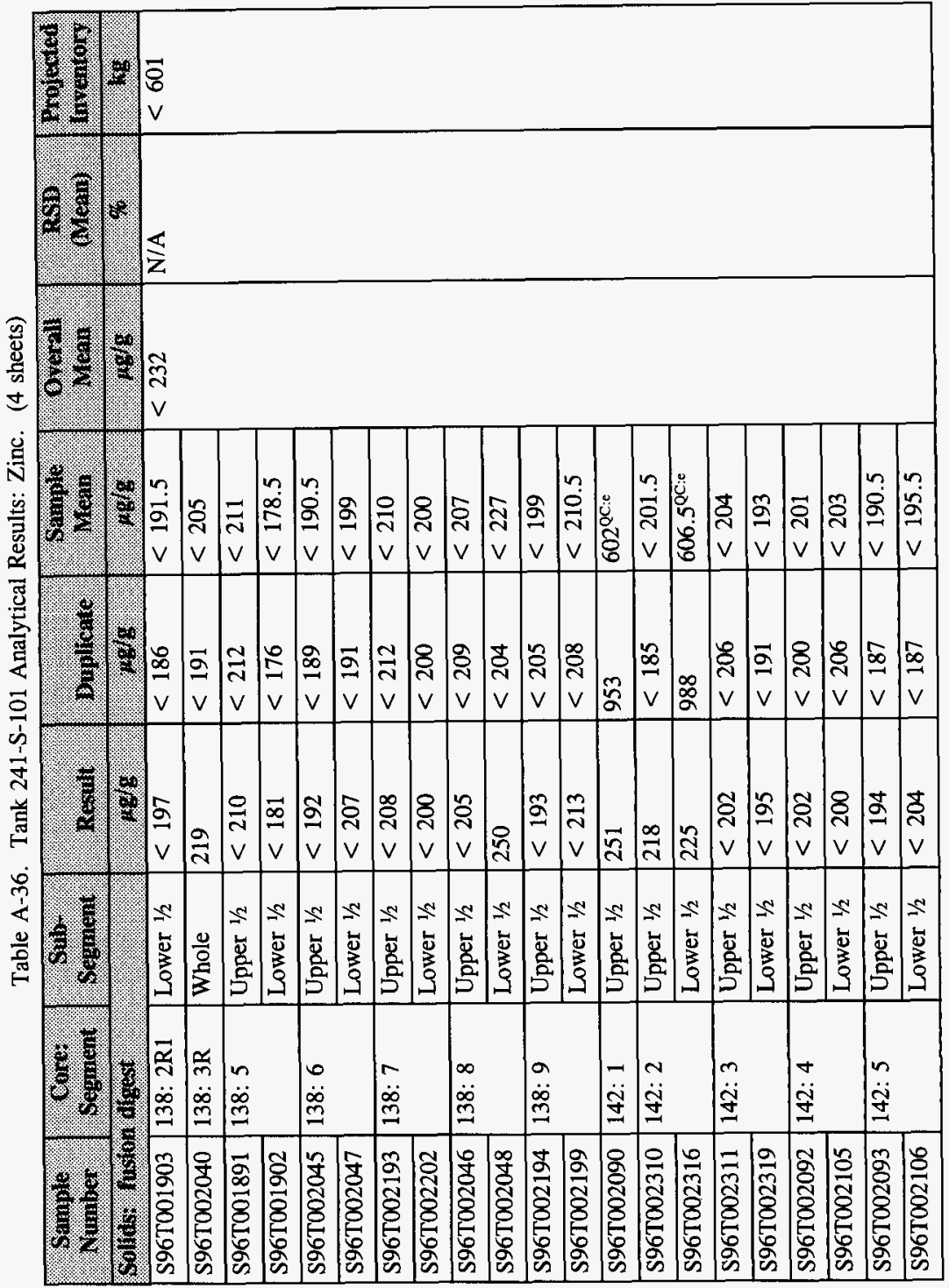


Table A-36. Tank 241-S-101 Analytical Results: Zinc. (4 sheets)

\begin{tabular}{|c|c|c|c|c|c|c|c|c|}
\hline Gounge. & sognom & 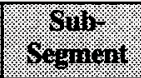 & hesting & Binligate & 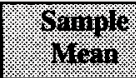 & (1) 1 rall & Mispin & Woldorol \\
\hline \multicolumn{3}{|c|}{ 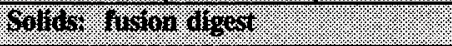 } & 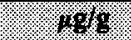 & 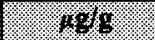 & 6ro & 498 & 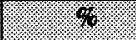 & 梦 \\
\hline S96T002094 & 142: 6 & Upper $1 / 2$ & $<207$ & $<203$ & $<205$ & \multirow[t]{6}{*}{ Cont. } & \multirow[t]{6}{*}{ Cont. } & \multirow[t]{6}{*}{ Cont. } \\
\hline S96T002091 & & Lower $1 / 2$ & $<206$ & $<205$ & $<205.5$ & & & \\
\hline S96T002095 & \multirow[t]{2}{*}{ 142: 7} & Upper $1 / 2$ & $<199$ & $<201$ & $<200$ & & & \\
\hline \$96T002107 & & Lower $1 / 2$ & $<215$ & $<217$ & $<216$ & & & \\
\hline \$96T002096 & \multirow[t]{2}{*}{ 142: 8} & Upper $1 / 2$ & $<199$ & $<198$ & $<198.5$ & & & \\
\hline S96T002108 & & Lower $1 / 2$ & $<204$ & $<200$ & $<202$ & & & \\
\hline \multicolumn{3}{|c|}{ Soluts, and digest } & $19 \mathrm{~g} / \mathrm{g}$ & 1.498. & 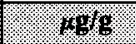 & $119 \%$ & $1 \%$ & 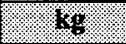 \\
\hline S96T001905 & 138: 2R1 & Lower $1 / 2$ & 29.5 & 29.6 & 29.55 & \multirow[t]{14}{*}{27.8} & \multirow[t]{14}{*}{7.0} & \multirow[t]{14}{*}{72.1} \\
\hline S96T001892 & \multirow[t]{2}{*}{$138: 5$} & Upper $1 / 2$ & 18.2 & 19.2 & 18.7 & & & \\
\hline S96T001904 & & Lower $1 / 2$ & 25.9 & 29.3 & 27.6 & & & \\
\hline S96T002049 & \multirow[t]{2}{*}{$138: 6$} & Upper $1 / 2$ & 15.7 & 19.4 & $17.55^{\mathrm{QC}: \mathrm{e}}$ & & & \\
\hline S96T002050 & & Lower $1 / 2$ & 17 & 24.9 & $20.95^{\mathrm{QC}: e}$ & & & \\
\hline S96T002195 & \multirow[t]{2}{*}{ 138: 7} & Upper $1 / 2$ & 45.6 & 29.4 & $37.5^{\mathrm{QC}: \mathrm{e}}$ & & & \\
\hline S96T002203 & & Lower $1 / 2$ & 28.1 & 30.1 & 29.1 & & & \\
\hline S96T002051 & \multirow[t]{2}{*}{ 138: 8} & Upper $1 / 2$ & 19.7 & 22.9 & 21.3 & & & \\
\hline \$96T002052 & & Lower $1 / 2$ & 25.8 & 26.3 & 26.05 & & & \\
\hline S96T002196 & \multirow[t]{2}{*}{ 138: 9} & Upper $1 / 2$ & 41.1 & 35.7 & 38.4 & & & \\
\hline S96T002200 & & Lower $1 / 2$ & 26.6 & 27.2 & 26.9 & & & \\
\hline S96T002097 & 142: 1 & Upper $1 / 2$ & 30 & 32.1 & 31.05 & & & \\
\hline S96T002312 & \multirow[t]{2}{*}{$142: 2$} & Upper $1 / 2$ & 39.6 & $\overline{31.4}$ & $35.5^{\mathrm{QC}: \mathrm{e}}$ & & & \\
\hline S96T002317 & & Lower $1 / 2$ & 34.1 & 39.4 & 36.75 & & & \\
\hline
\end{tabular}


Table A-36. Tank 241-S-101 Analytical Results: Zinc. (4 sheets)

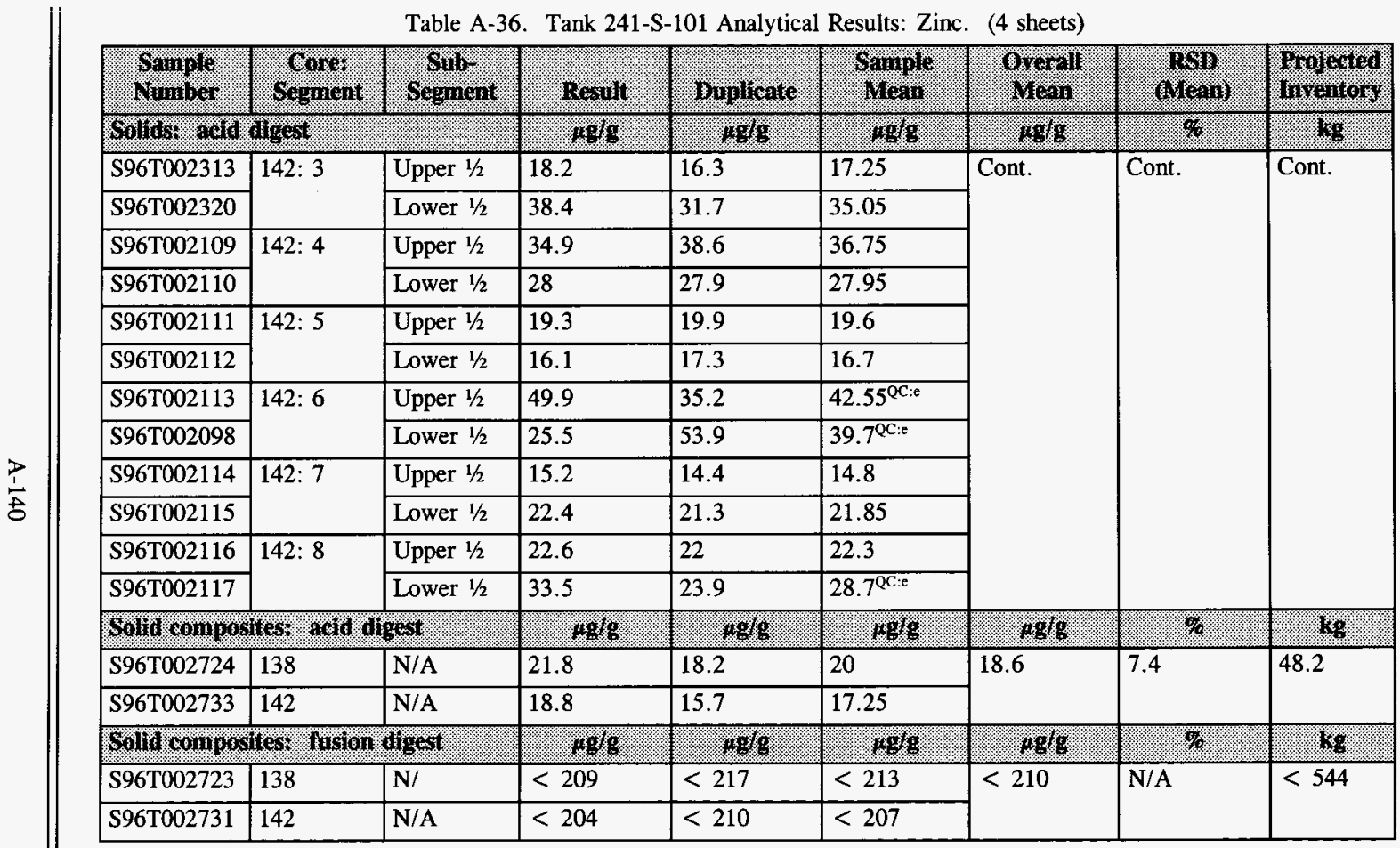


Table A-36. Tank 241-S-101 Analytical Results: Zinc. (4 sheets)

\begin{tabular}{|c|c|c|c|c|c|c|c|c|}
\hline Shined & \%ognont & 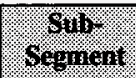 & Resint & oluilsole & Wholo & 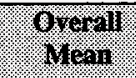 & $\log 10$ & 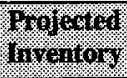 \\
\hline \multicolumn{3}{|c|}{ 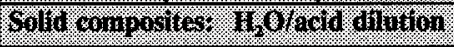 } & $6 \% 8$ & $4 \% 16$ & 1048 & 1010 & 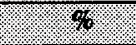 & 183 \\
\hline S96T002726 & 138 & N/A & 9.29 & 8.01 & 8.65 & \multirow[t]{2}{*}{6.96} & \multirow[t]{2}{*}{24.4} & \multirow[t]{2}{*}{18.0} \\
\hline S96T002736 & 142 & N/A & $<5.48$ & $<5.04$ & $<5.26$ & & & \\
\hline \multicolumn{3}{|c|}{ 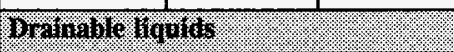 } & 10/mi. & $1 \% 1 \mathrm{~mL}$ & Fofrul & 196110 & $\%$ & 18: \\
\hline S96T001886 & 138: 1R & DL & 19.4 & 19.3 & 19.35 & \multirow[t]{3}{*}{28.6} & \multirow[t]{3}{*}{27.5} & \multirow[t]{3}{*}{1.29} \\
\hline S96T001909 & 138: 2R1 & $\mathrm{DL}$ & 43.9 & 44.4 & 44.15 & & & \\
\hline S96T002043 & 138: 3R & DL & 22.5 & 21.8 & 22.15 & & & \\
\hline
\end{tabular}


Table A-37. Tank 241-S-101 Analytical Results: Zirconium. (4 sheets)

\begin{tabular}{|c|c|c|c|c|c|c|c|c|}
\hline Monglo & 48 & o. & Etoug & Buplisale & 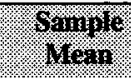 & $\begin{array}{l}64 \% 11 \\
162 n\end{array}$ & 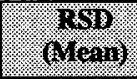 & 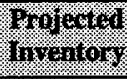 \\
\hline \multicolumn{3}{|c|}{ 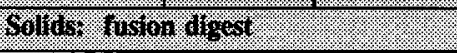 } & $18 \%$ & $18 / 9$ & 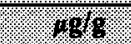 & $1.18 \mathrm{~g}$ & \% & (1) \\
\hline S96T001903 & 138: 2R1 & Lower $1 / 2$ & $<197$ & $<186$ & $<191.5$ & \multirow[t]{21}{*}{$<200$} & \multirow[t]{21}{*}{$\mathrm{N} / \mathrm{A}$} & \multirow[t]{21}{*}{$<518$} \\
\hline S96T002040 & 138: $3 \mathrm{AR}$ & Whole & $<204$ & $<191$ & $<197.5$ & & & \\
\hline S96T001891 & \multirow[t]{2}{*}{$138: 5$} & Upper $1 / 2$ & $<210$ & $<212$ & $<211$ & & & \\
\hline S96T001902 & & Lower $1 / 2$ & $<181$ & $<176$ & $<178.5$ & & & \\
\hline S96T002045 & \multirow[t]{2}{*}{ 138: 6} & Upper $1 / 2$ & $<192$ & $<189$ & $<190.5$ & & & \\
\hline S96T002047 & & Lower $1 / 2$ & $<207$ & $<191$ & $<199$ & & & \\
\hline S96T002193 & \multirow[t]{2}{*}{ 138: 7} & Upper $1 / 2$ & $<208$ & $<212$ & $<210$ & & & \\
\hline S96T002202 & & Lower $1 / 2$ & $<200$ & $<200$ & $<200$ & & & \\
\hline S96T002046 & \multirow[t]{2}{*}{ 138: 8} & Upper $1 / 2$ & $<205$ & $<209$ & $<207$ & & & \\
\hline S96T002048 & & Lower $1 / 2$ & $<189$ & $<204$ & $<196.5$ & & & \\
\hline S96T002194 & \multirow[t]{2}{*}{ 138: 9} & Upper $1 / 2$ & $<193$ & $<205$ & $<199$ & & & \\
\hline S96T002199 & & Lower $1 / 2$ & $<213$ & $<208$ & $<210.5$ & & & \\
\hline S96T002090 & 142: 1 & Upper $1 / 2$ & $<206$ & $<205$ & $<205.5$ & & & \\
\hline S96T002310 & \multirow[t]{2}{*}{ 142: 2} & Upper $1 / 2$ & $<188$ & $<185$ & $<186.5$ & & & \\
\hline S96T002316 & & Lower $1 / 2$ & $<204$ & $<203$ & $<203.5$ & & & \\
\hline \$96T002311 & \multirow[t]{2}{*}{$142: 3$} & Upper $1 / 2$ & $<202$ & $<206$ & $<204$ & & & \\
\hline S96T002319 & & Lower $1 / 2$ & $<195$ & $<191$ & $<193$ & & & \\
\hline S96T002092 & \multirow[t]{2}{*}{$142: 4$} & Upper $1 / 2$ & $<202$ & $<200$ & $<201$ & & & \\
\hline S96T002105 & & Lower $1 / 2$ & $<200$ & $<206$ & $<203$ & & & \\
\hline S96T002093 & \multirow[t]{2}{*}{$142: 5$} & Upper $1 / 2$ & $<194$ & $<187$ & $<190.5$ & & & \\
\hline S96T002106 & & Lower $1 / 2$ & $<204$ & $<187$ & $<195.5$ & & & \\
\hline
\end{tabular}


Table A-37. Tank 241-S-101 Analytical Results: Zirconium. (4 sheets)

\begin{tabular}{|c|c|c|c|c|c|c|c|c|}
\hline 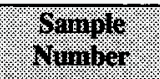 & ofmorest & sognof & Tresint? & Biplicate & 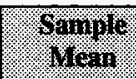 & 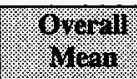 & $\begin{array}{l}1319 \\
(10011)\end{array}$ & Whoritor \\
\hline \multicolumn{3}{|c|}{ 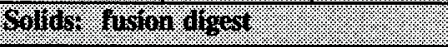 } & $198 \mathrm{~g}$ & $6.181 \mathrm{~s}$ & 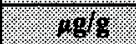 & $110 \mathrm{~g}$ & (2) & . $18 \mathrm{~s}$ \\
\hline S96T002094 & 142: 6 & Upper $1 / 2$ & $<207$ & $<203$ & $<205$ & \multirow[t]{6}{*}{ Cont. } & \multirow[t]{6}{*}{ Cont. } & \multirow[t]{6}{*}{ Cont. } \\
\hline S96T002091 & & Lower $1 / 2$ & $<206$ & $<205$ & $<205.5$ & & & \\
\hline S96T002095 & \multirow[t]{2}{*}{ 142: 7} & Upper $1 / 2$ & $<199$ & $<201$ & $<200$ & & & \\
\hline S96T002107 & & Lower $1 / 2$ & $<215$ & $<217$ & $<216$ & & & \\
\hline \$96T002096 & \multirow[t]{2}{*}{ 142: 8} & Upper $1 / 2$ & $<199$ & $<198$ & $<198.5$ & & & \\
\hline S96T002108 & & Lower $1 / 2$ & $<204$ & $<200$ & $<202$ & & & \\
\hline \multicolumn{3}{|c|}{ solus, protagert } & 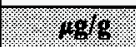 & 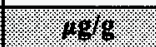 & 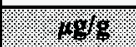 & 1818 & \% & 68 \\
\hline S96T001905 & 138: 2R1 & Lower $1 / 2$ & 15.3 & 15.7 & 15.5 & \multirow[t]{14}{*}{22.7} & \multirow[t]{14}{*}{16.5} & \multirow[t]{14}{*}{58.8} \\
\hline S96T001892 & \multirow[t]{2}{*}{$138: 5$} & Upper $1 / 2$ & 16 & 17.3 & 16.65 & & & \\
\hline S96T001904 & & Lower $1 / 2$ & 11.9 & 12.9 & 12.4 & & & \\
\hline S96T002049 & \multirow[t]{2}{*}{ 138: 6} & Upper $1 / 2$ & 18.1 & 19.9 & 19 & & & \\
\hline S96T002050 & & Lower $1 / 2$ & 23.8 & 26.8 & 25.3 & & & \\
\hline S96T002195 & \multirow[t]{2}{*}{ 138: 7} & Upper $1 / 2$ & 27.2 & 27.6 & 27.4 & & & \\
\hline S96T002203 & & Lower $1 / 2$ & 30.7 & 34.4 & 32.55 & & & \\
\hline S96T002051 & \multirow[t]{2}{*}{ 138: 8} & Upper $1 / 2$ & 35.3 & 35.2 & 35.25 & & & \\
\hline S96T002052 & & Lower $1 / 2$ & 40.2 & 39.3 & 39.75 & & & \\
\hline S96T002196 & \multirow[t]{2}{*}{ 138: 9} & Upper $1 / 2$ & 54.1 & 56.4 & 55.25 & & & \\
\hline S96T002200 & & Lower $1 / 2$ & 19.5 & 20.1 & 19.8 & & & \\
\hline S96T002097 & 142: 1 & Upper $1 / 2$ & 9.98 & 10.1 & 10.04 & & & \\
\hline S96T002312 & \multirow[t]{2}{*}{$142: 2$} & Upper $1 / 2$ & 11 & 9.9 & 10.45 & & & \\
\hline S96T002317 & & Lower $1 / 2$ & 10.5 & 11.3 & 10.9 & & & \\
\hline
\end{tabular}


Table A-37. Tank 241-S-101 Analytical Results: Zirconium. (4 sheets)

\begin{tabular}{|c|c|c|c|c|c|c|c|c|}
\hline Whapolor & \% & 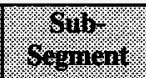 & Wonth & Bullingere & Mengin & \multirow{2}{*}{ 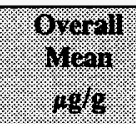 } & \multirow{2}{*}{ orm } & \multirow{2}{*}{ 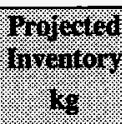 } \\
\hline \multicolumn{3}{|c|}{ Solus } & (3. & 1.9648. & 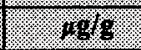 & & & \\
\hline S96T002313 & \multirow[t]{2}{*}{$142: 3$} & Upper $1 / 2$ & 23.5 & 20 & 21.75 & \multirow[t]{12}{*}{ Cont. } & \multirow[t]{12}{*}{ Cont. } & \multirow[t]{12}{*}{ Cont. } \\
\hline S96T002320 & & Lower $1 / 2$ & 8.93 & 9.57 & 9.25 & & & \\
\hline S96T002109 & \multirow[t]{2}{*}{$142: 4$} & Upper $1 / 2$ & 11.4 & 11 & 11.2 & & & \\
\hline S96T002110 & & Lower $1 / 2$ & 12.5 & 13.3 & 12.9 & & & \\
\hline S96T002111 & \multirow[t]{2}{*}{$142: 5$} & Upper $1 / 2$ & 8.77 & 12.5 & $10.635^{\mathrm{QC}: \mathrm{e}}$ & & & \\
\hline S96T002112 & & Lower $1 / 2$ & 17.2 & 17.9 & 17.55 & & & \\
\hline S96T002113 & \multirow[t]{2}{*}{ 142: 6} & Upper $1 / 2$ & 8.49 & 9.48 & 8.985 & & & \\
\hline S96T002098 & & Lower $1 / 2$ & 23 & 38.3 & $30.65^{\mathrm{QC}: \mathrm{e}}$ & & & \\
\hline S96T002114 & \multirow[t]{2}{*}{$142: 7$} & Upper $1 / 2$ & 25 & 25.4 & 25.2 & & & \\
\hline S96T002115 & & Lower $1 / 2$ & 36.5 & 35.8 & 36.15 & & & \\
\hline \$96T002116 & \multirow[t]{2}{*}{$142: 8$} & Upper $1 / 2$ & 44.6 & 43.6 & 44.1 & & & \\
\hline S96T002117 & & Lower $1 / 2$ & 36.8 & 28 & $32.4^{\mathrm{QC}: c}$ & & & \\
\hline \multicolumn{3}{|c|}{ 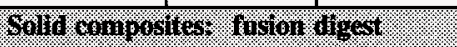 } & 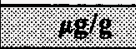 & 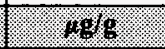 & 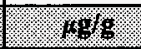 & 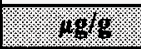 & $\sqrt{1} .9$. & $\sqrt{18}$ \\
\hline S96T002723 & 138 & N/A & $<209$ & $<217$ & $<213$ & \multirow[t]{2}{*}{$<210$} & \multirow[t]{2}{*}{ N/A } & \multirow[t]{2}{*}{$<544$} \\
\hline S96T002731 & 142 & $\mathbf{N} / \mathbf{A}$ & $<204$ & $<210$ & $<207$ & & & \\
\hline \multicolumn{3}{|c|}{ 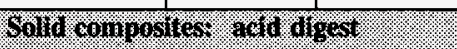 } & 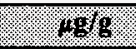 & 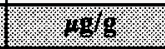 & 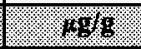 & 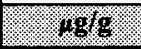 & . & \% \\
\hline S96T002724 & 138 & $\mathrm{~N} / \mathrm{A}$ & 29.6 & 29.1 & 29.35 & \multirow[t]{2}{*}{25.6} & \multirow[t]{2}{*}{14.8} & \multirow[t]{2}{*}{66.4} \\
\hline S96T002733 & 142 & N/A & 21.3 & 22.3 & 21.8 & & & \\
\hline
\end{tabular}


Table A-37. Tank 241-S-101 Analytical Results: Zirconium. (4 sheets)

\begin{tabular}{|c|c|c|c|c|c|c|c|c|}
\hline Kanowh & 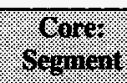 & ochont & Rerail & Bullowie & 191010 & orefil & 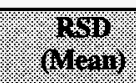 & Whorirom \\
\hline \multicolumn{3}{|c|}{ 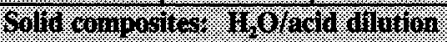 } & $4 \%$ & $10 \%$ & 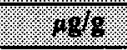 & . 194 & \% & Ke: \\
\hline S96T002726 & 138 & N/A & $<5.62$ & $<5.46$ & $<5.54$ & \multirow[t]{2}{*}{$<5.40$} & \multirow[t]{2}{*}{ N/A } & \multirow[t]{2}{*}{$<14.0$} \\
\hline S96T002736 & 142 & N/A & $<5.48$ & $<5.04$ & $<5.26$ & & & \\
\hline \multicolumn{3}{|c|}{ 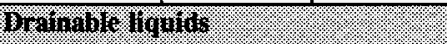 } & $148 \ln$ & $19.9 \mathrm{~m}$ & atal & $169 \mathrm{~m}$ & $\%$ & Wg \\
\hline S96T001886 & 138: $1 \mathrm{R}$ & DL & $<4.01$ & $<4.01$ & $<4.01$ & \multirow[t]{3}{*}{$<4.01$} & \multirow[t]{3}{*}{ N/A } & \multirow[t]{3}{*}{$<0.180$} \\
\hline \$96T001909 & 138: 2R1 & DL & $<4.01$ & $<4.01$ & $<4.01$ & & & \\
\hline S96T002043 & 138: 3R & DL & $<4.01$ & $<4.01$ & $<4.01$ & & & \\
\hline
\end{tabular}


Table A-40. Tank 241-S-101 Analytical Results: Chloride. (2 sheets)

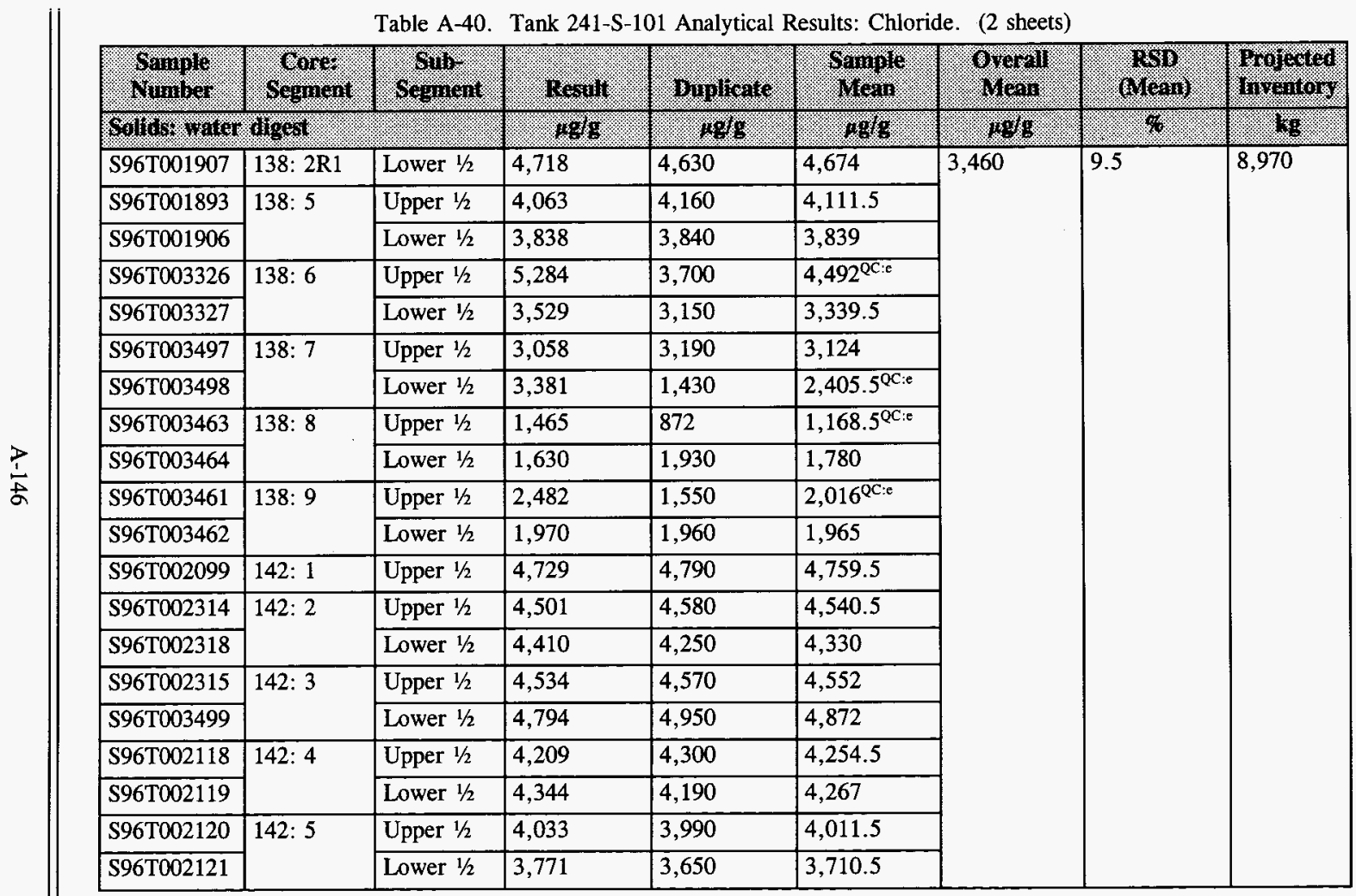


Table A-40. Tank 241-S-101 Analytical Results: Chloride. (2 sheets)

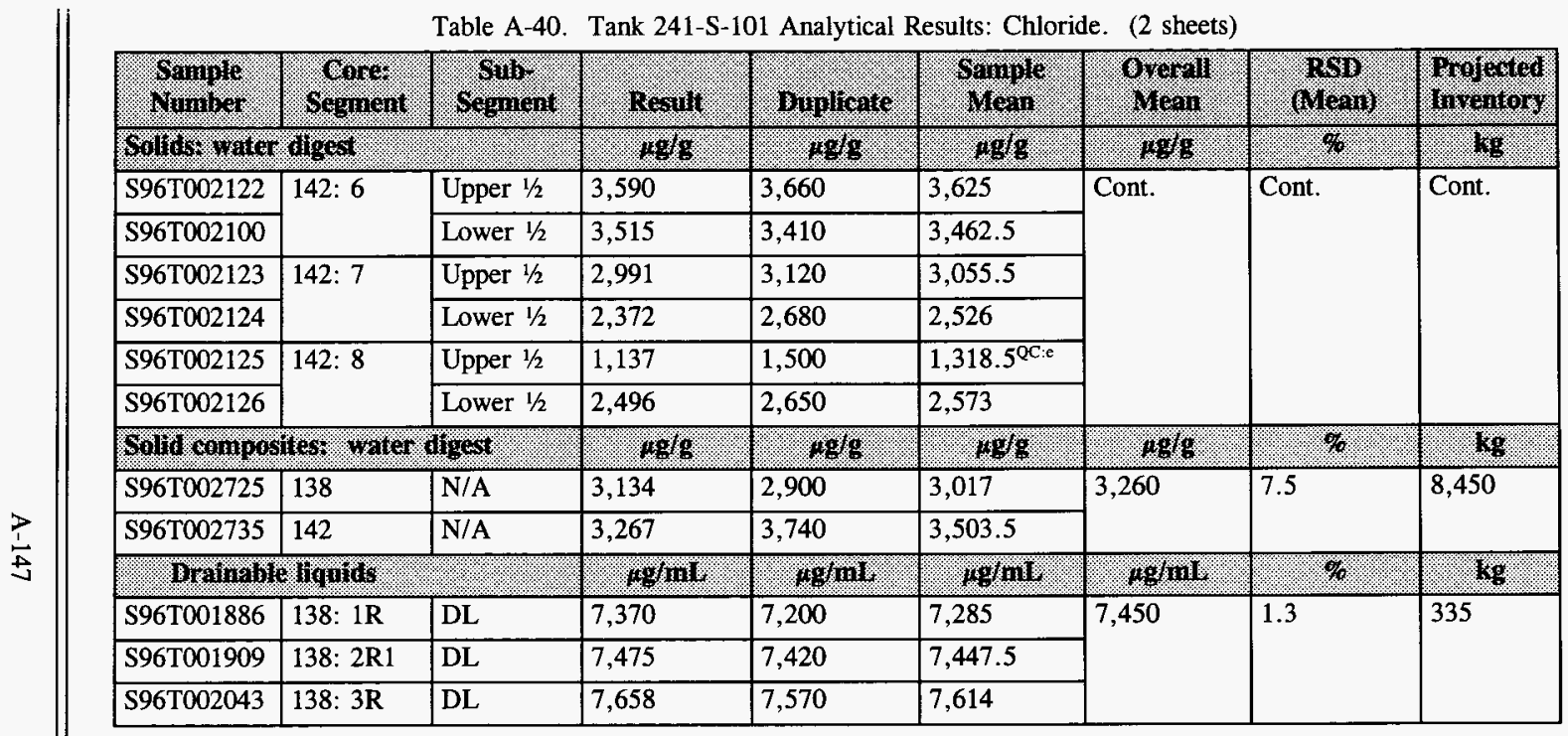


WHC-SD-WM-ER-613 Rev. 0

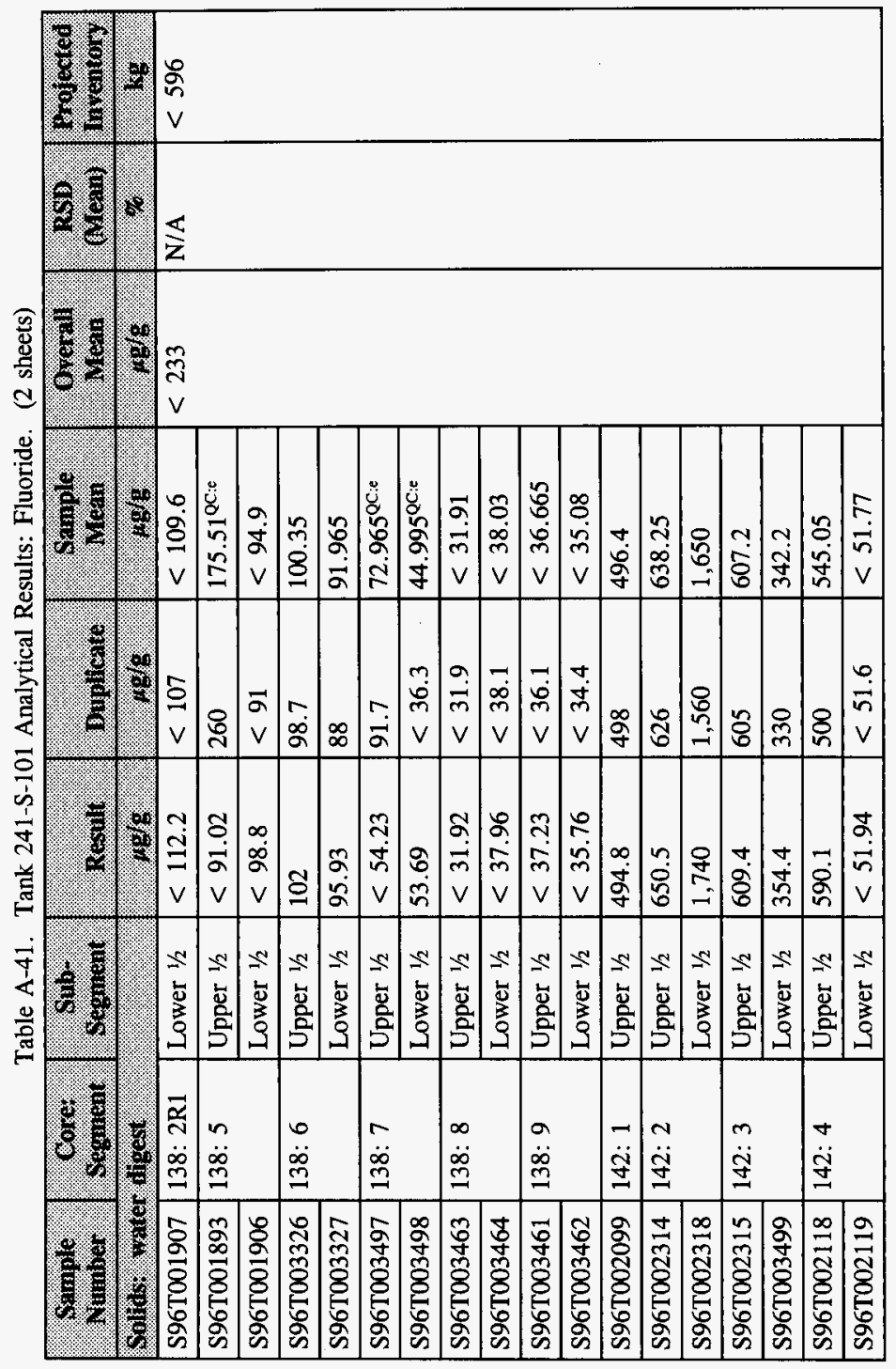




\begin{tabular}{|c|c|c|c|c|c|c|c|c|}
\hline \multirow[b]{3}{*}{$L L^{\prime} t>$} & \multirow[b]{3}{*}{$\forall / N$} & \multirow[b]{3}{*}{$90 \mathrm{I}>$} & SI8. $\varepsilon \subseteq>$ & $8^{\circ} \varepsilon \varsigma>$ & $\varepsilon 8^{\circ} \varepsilon \varsigma>$ & Тם & $\mathrm{X \varepsilon}: 8 \varepsilon \mathrm{I}$ & $\varepsilon \neq 0 z 00 \mathrm{~L} 96 \mathrm{~S}$ \\
\hline & & & 8 Z ZEI > & EEI > & $9 \cdot Z \varepsilon I>$ & TU & 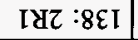 & 606I00L96S \\
\hline & & & $8 \cdot Z \varepsilon I>$ & $\varepsilon E I>$ & $9 \cdot \tau \varepsilon I>$ & $7 \mathrm{Ta}$ & \&I :8EI & 988 I00L96S \\
\hline 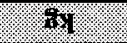 & 6.96 & 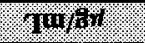 & 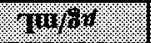 & Tuनrl: & WOWH: & \multicolumn{3}{|c|}{ spinbil mqguigua } \\
\hline \multirow[b]{2}{*}{998} & \multirow[b]{2}{*}{$\forall 0 L$} & \multirow[b]{2}{*}{$\downarrow \varepsilon \varepsilon$} & $2: 0059 \cdot 895$ & 666 & $\varepsilon 8 \varepsilon \mathrm{I}$ & $\mathrm{V} / \mathrm{N}$ & $2 t \mathrm{I}$ & SELZ00L96S \\
\hline & & & : & $8 \varepsilon I$ & $6 L \cdot 6 S>$ & $\mathbf{V} / \mathrm{N}$ & $8 \varepsilon \mathrm{I}$ & SZLZOOLI96S \\
\hline G) & $28:$ & $8 \%$ & $80 \%=1$ & 8for & 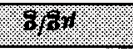 & \multicolumn{3}{|c|}{ 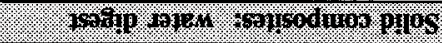 } \\
\hline \multirow{8}{*}{ · } & \multirow{8}{*}{.1400 } & \multirow[b]{7}{*}{ 'puop } & $2: 00<-80 Z$ & t.9S > & I9E & $2 / 1$ IOMOT & \multirow[b]{2}{*}{$8: Z t I$} & 9ZIZ00LI96S \\
\hline & & & $\$ 6.9 z>$ & $\varsigma^{-} 9 \tau>$ & $\nabla L Z>$ & t/1 $\operatorname{tadd}_{\Lambda}$ & & SZIZ00L96S \\
\hline & & & $56 \varepsilon^{\prime} 6 t>$ & $z \cdot 0 \varsigma>$ & $6 S^{\circ} 8 \mathrm{t}>$ & $z / 1 \mathrm{I}$ & \multirow[b]{2}{*}{$L: \tau t I$} & $t Z I Z 00 L 96 S$ \\
\hline & & & t0. $\mathrm{ES}>$ & $\varepsilon 0 S>$ & $8 L \cdot S \subseteq>$ & $z / 1$ Jədd $\Omega$ & & EZIZ00L96S \\
\hline & & & $\varsigma 88^{\circ} \varepsilon \varsigma>$ & {$[\cdot t s>$} & $\angle 9^{\circ} \varepsilon \subseteq>$ & $z / 1$ IәMOT & \multirow[b]{2}{*}{$9: Z+I$} & $00 I 200 . \mathrm{L} 96 \mathrm{~S}$ \\
\hline & & & $\varsigma 86 \bullet \varsigma>$ & s'ss > & $L t^{\circ} t S>$ & $z / \mathrm{J} \mathrm{d} d \mathrm{~d}_{\Omega}$ & & $2 Z I Z 00 \mathrm{~L} 96 \mathrm{~S}$ \\
\hline & & & $S t t^{\circ} 0 S>$ & $L^{\circ} 6 t>$ & $6 I^{\circ} I S>$ & Z/1 Iәмот & \multirow[b]{2}{*}{$s: Z t I$} & IZIZ00L96S \\
\hline & & & $6 t^{\circ}$ IS $>$ & $8 \cdot 25>$ & $8 I^{\circ} O S>$ & $z / 1 \mathrm{~J}$ 'dd $\Omega$ & & 0ZIZ00L96S \\
\hline $.8 \%$ & 6. & of & hat & by & $6 \%$ \% & ? & \multicolumn{2}{|c|}{ 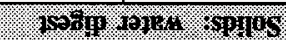 } \\
\hline 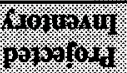 & $\begin{array}{l}\text { mewh) } \\
\text { astd }\end{array}$ & 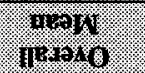 & $\begin{array}{l}\text { imayi: } \\
\text { oddunts }\end{array}$ & onosyding & Hosaty & $\begin{array}{l}\text { momings } \\
\text {-ains }\end{array}$ & 7romoros & oquming \\
\hline
\end{tabular}

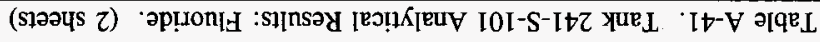


Table A-42. Tank 241-S-101 Analytical Results: Nitrate. (2 sheets)

\begin{tabular}{|c|c|c|c|c|c|c|c|c|}
\hline Gomile & W. & 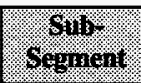 & Resinil & Builicate & Worion & Wor & 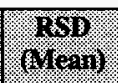 & mogrof \\
\hline \multicolumn{3}{|c|}{ 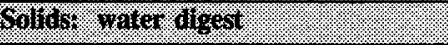 } & 1898 & 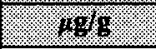 & 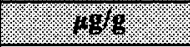 & 1.996 & . & (3) \\
\hline S96T001907 & 138: 2R1 & Lower $1 / 2$ & $3.327 \mathrm{E}+05$ & $3.240 \mathrm{E}+05$ & $3.284 \mathrm{E}+05$ & \multirow[t]{15}{*}{$1.62 \mathrm{E}+05$} & \multirow[t]{15}{*}{25.1} & \multirow[t]{15}{*}{$4.20 \mathrm{E}+05$} \\
\hline S96T001893 & 138: 5 & Upper $1 / 2$ & $3.105 \mathrm{E}+05$ & $3.490 \mathrm{E}+05$ & $3.298 \mathrm{E}+05$ & & & \\
\hline \$96T003327 & 138: 6 & Lower $1 / 2$ & $1.584 \mathrm{E}+05$ & $1.550 \mathrm{E}+05$ & $1.567 \mathrm{E}+05$ & & & \\
\hline S96T003497 & \multirow[t]{2}{*}{$138: 7$} & Upper $1 / 2$ & $1.613 \mathrm{E}+05$ & $1.710 \mathrm{E}+05$ & $1.662 \mathrm{E}+05$ & & & \\
\hline S96T003498 & & Lower $1 / 2$ & $1.264 \mathrm{E}+05$ & 78,300 & $1.024 \mathrm{E}+05^{\mathrm{QC}: e}$ & & & \\
\hline S96T003463 & $138: 8$ & Upper $1 / 2$ & 83,530 & 44,700 & $64,115^{\mathrm{QC}: \mathrm{e}}$ & & & \\
\hline S96T002099 & 142: 1 & Upper $1 / 2$ & $1.118 \mathrm{E}+05$ & $1.160 \mathrm{E}+05$ & $1.139 \mathrm{E}+05$ & & & \\
\hline S96T002314 & \multirow[t]{2}{*}{ 142: 2} & Upper $1 / 2$ & $1.092 \mathrm{E}+05$ & $1.100 \mathrm{E}+05$ & $1.096 \mathrm{E}+05$ & & & \\
\hline S96T002318 & & Lower $1 / 2$ & $1.028 \mathrm{E}+05$ & $1.010 \mathrm{E}+05$ & $1.019 \mathrm{E}+05$ & & & \\
\hline \$96T002315 & \multirow[t]{2}{*}{$142: 3$} & Upper $1 / 2$ & $1.073 E+05$ & $1.100 \mathrm{E}+05$ & $1.087 \mathrm{E}+05$ & & & \\
\hline S96T003499 & & Lower $1 / 2$ & $1.050 \mathrm{E}+05$ & $1.110 \mathrm{E}+05$ & $1.080 \mathrm{E}+05$ & & & \\
\hline S96T002118 & \multirow[t]{2}{*}{ 142: 4} & Upper $1 / 2$ & $1.131 \mathrm{E}+05$ & $1.140 \mathrm{E}+05$ & $1.136 \mathrm{E}+05$ & & & \\
\hline S96T002119 & & Lower $1 / 2$ & $1.152 \mathrm{E}+05$ & $1.220 \mathrm{E}+05$ & $1.186 \mathrm{E}+05$ & & & \\
\hline S96T002120 & \multirow[t]{2}{*}{$142: 5$} & Upper $1 / 2$ & $1.340 \mathrm{E}+05$ & $1.250 \mathrm{E}+05$ & $1.295 \mathrm{E}+05$ & & & \\
\hline S96T002121 & & Lower $1 / 2$ & $1.278 \mathrm{E}+05$ & $1.310 \mathrm{E}+05$ & $1.294 \mathrm{E}+05$ & & & \\
\hline
\end{tabular}


Table A-42. Tank 241-S-101 Analytical Results: Nitrate. (2 sheets)

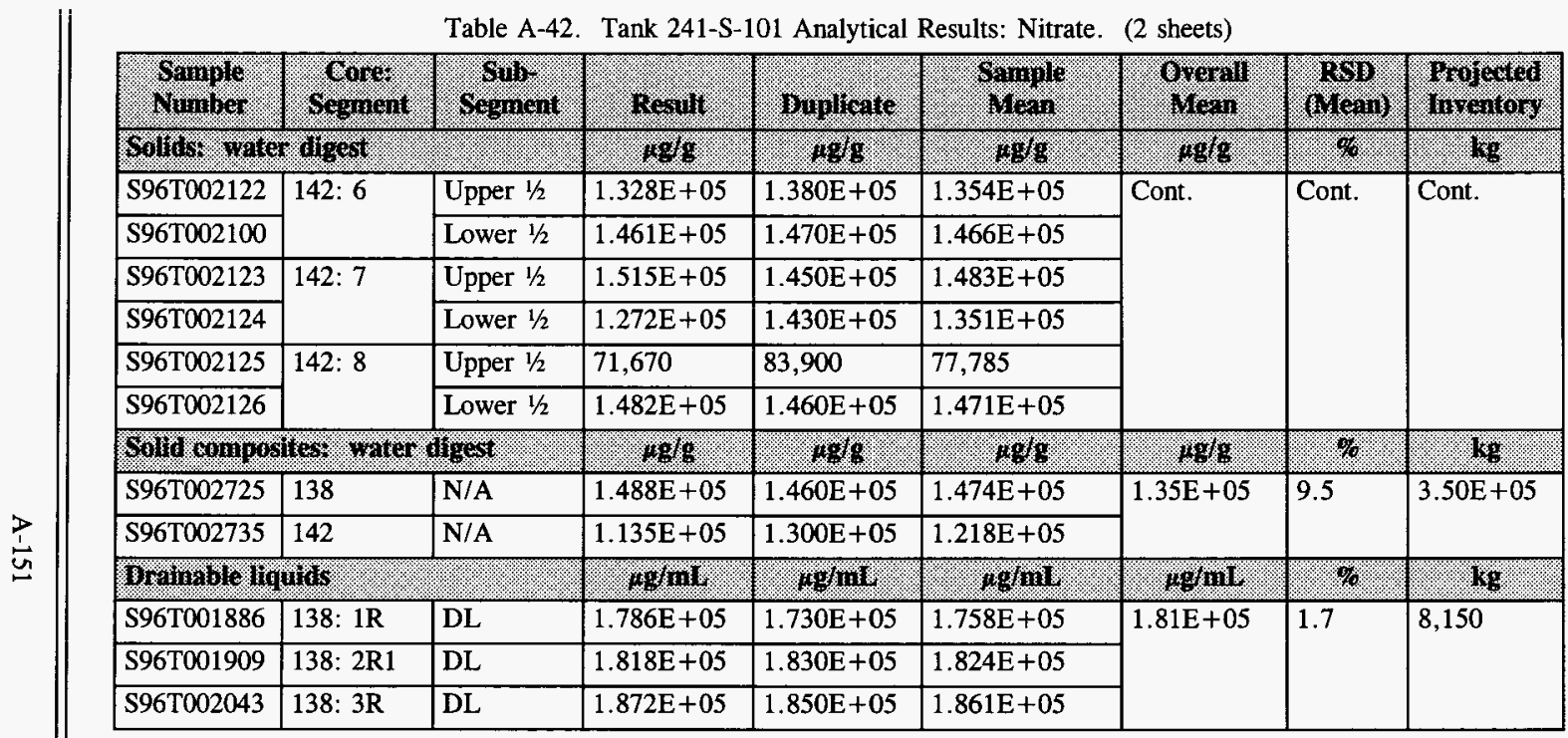


Table A-43. Tank 241-S-101 Analytical Results: Nitrite. (2 sheets)

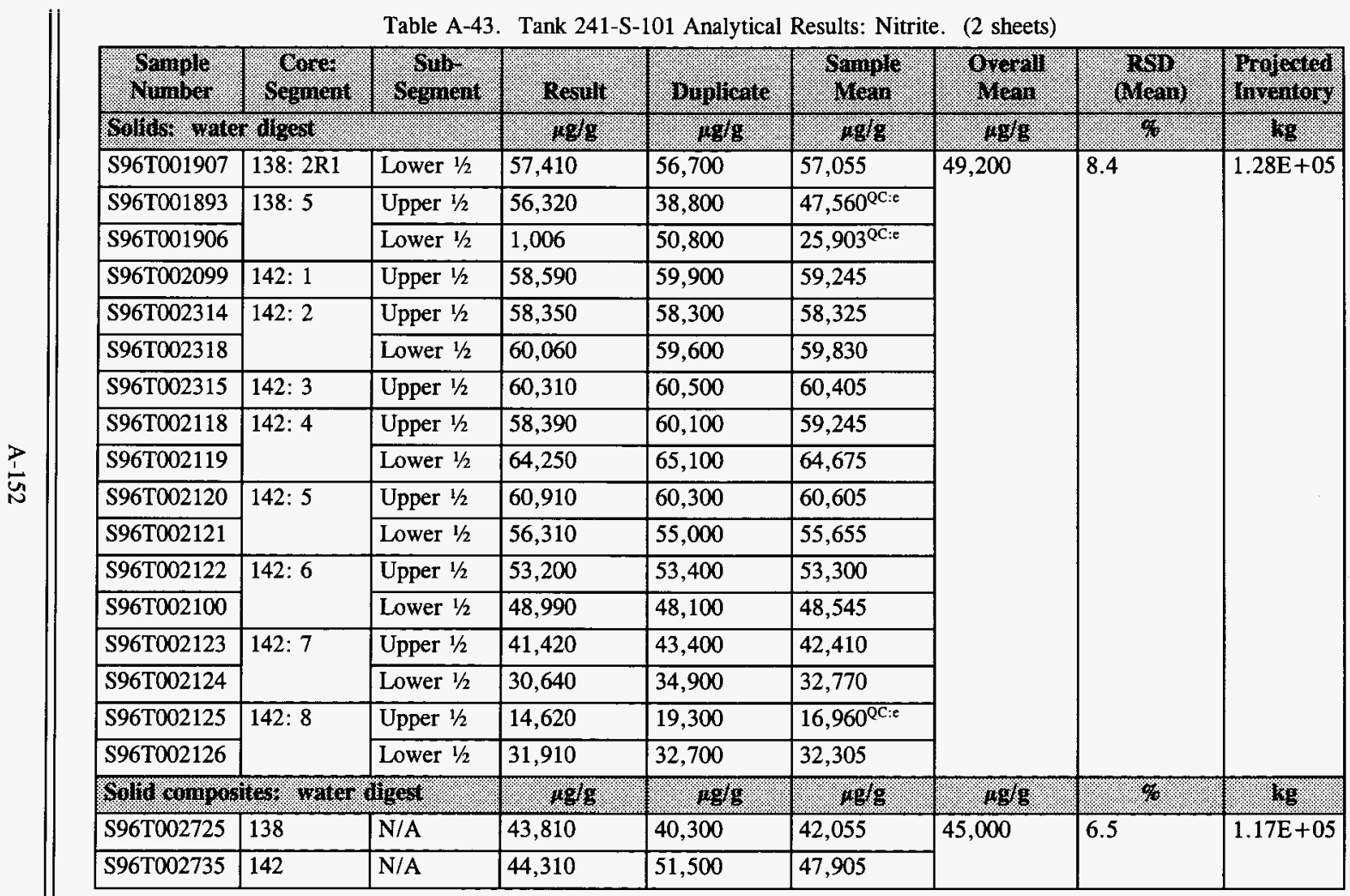


Table A-43. Tank 241-S-101 Analytical Results: Nitrite. (2 sheets)

\begin{tabular}{|c|c|c|c|c|c|c|c|c|}
\hline Wunor & osping & $40 \% 13 \%$ & resilit & Bublicale & \%orno & 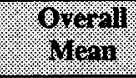 & 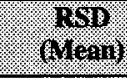 & 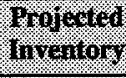 \\
\hline \multicolumn{3}{|c|}{ 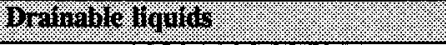 } & $681 \mathrm{mI}$ & $601 \mathrm{~m}$ & $4961 \mathrm{~m}$ & $141 \mathrm{ml}$ & 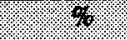 & 48 \\
\hline S96T001886 & 138: $1 \mathrm{R}$ & DL & 93,360 & 91,500 & 92,430 & \multirow[t]{3}{*}{94,000} & \multirow[t]{3}{*}{1.0} & \multirow[t]{3}{*}{4,230} \\
\hline S96T001909 & 138: 2R1 & DL & 93,480 & 94,700 & 94,090 & & & \\
\hline S96T002043 & 138: $3 \mathrm{R}$ & $\mathrm{DL}$ & 95,650 & 95,600 & 95,625 & & & \\
\hline
\end{tabular}


Table A-44. Tank 241-S-101 Analytical Results: Phosphate. (2 sheets)

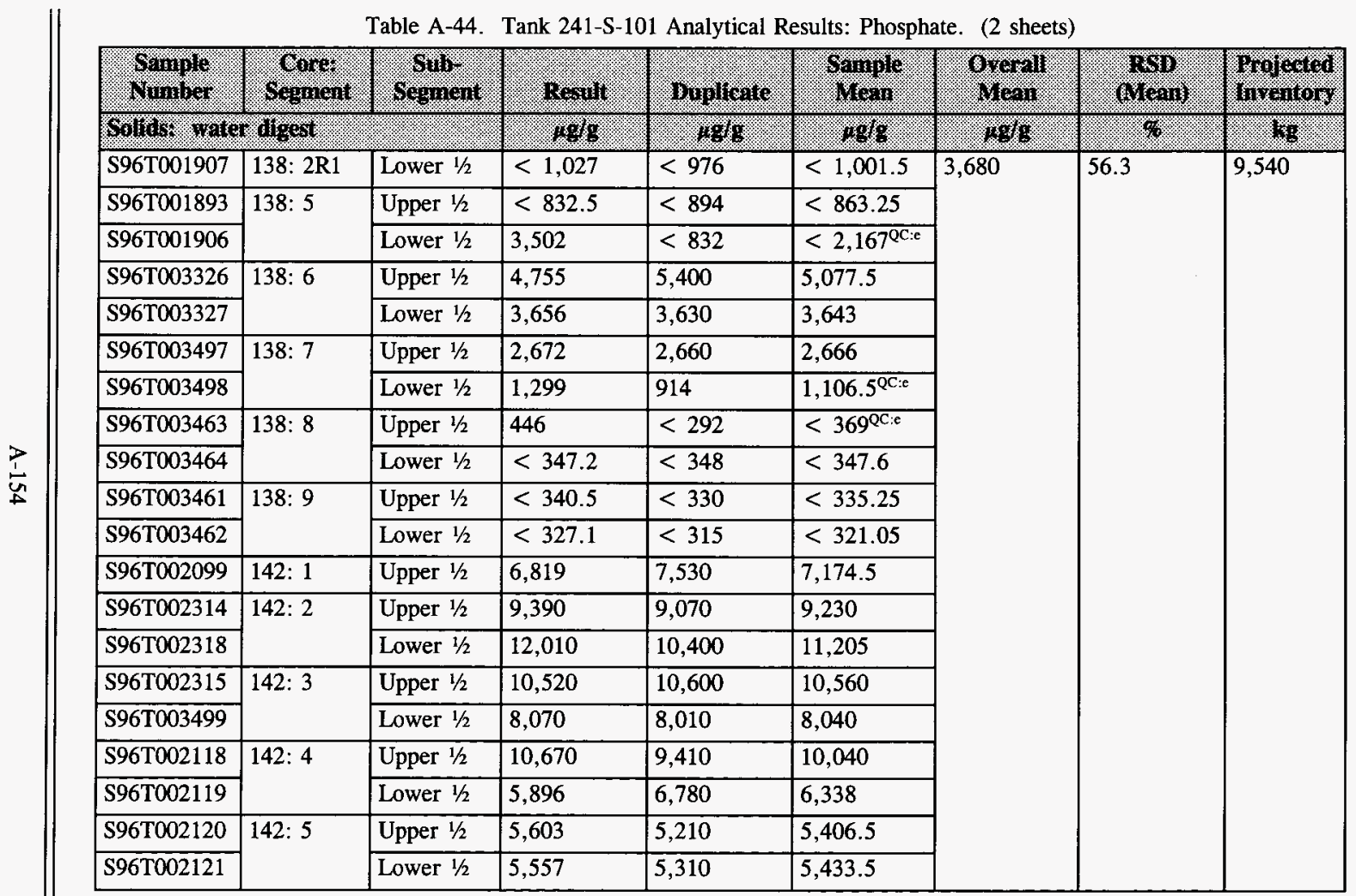


Table A-44. Tank 241-S-101 Analytical Results: Phosphate. (2 sheets)

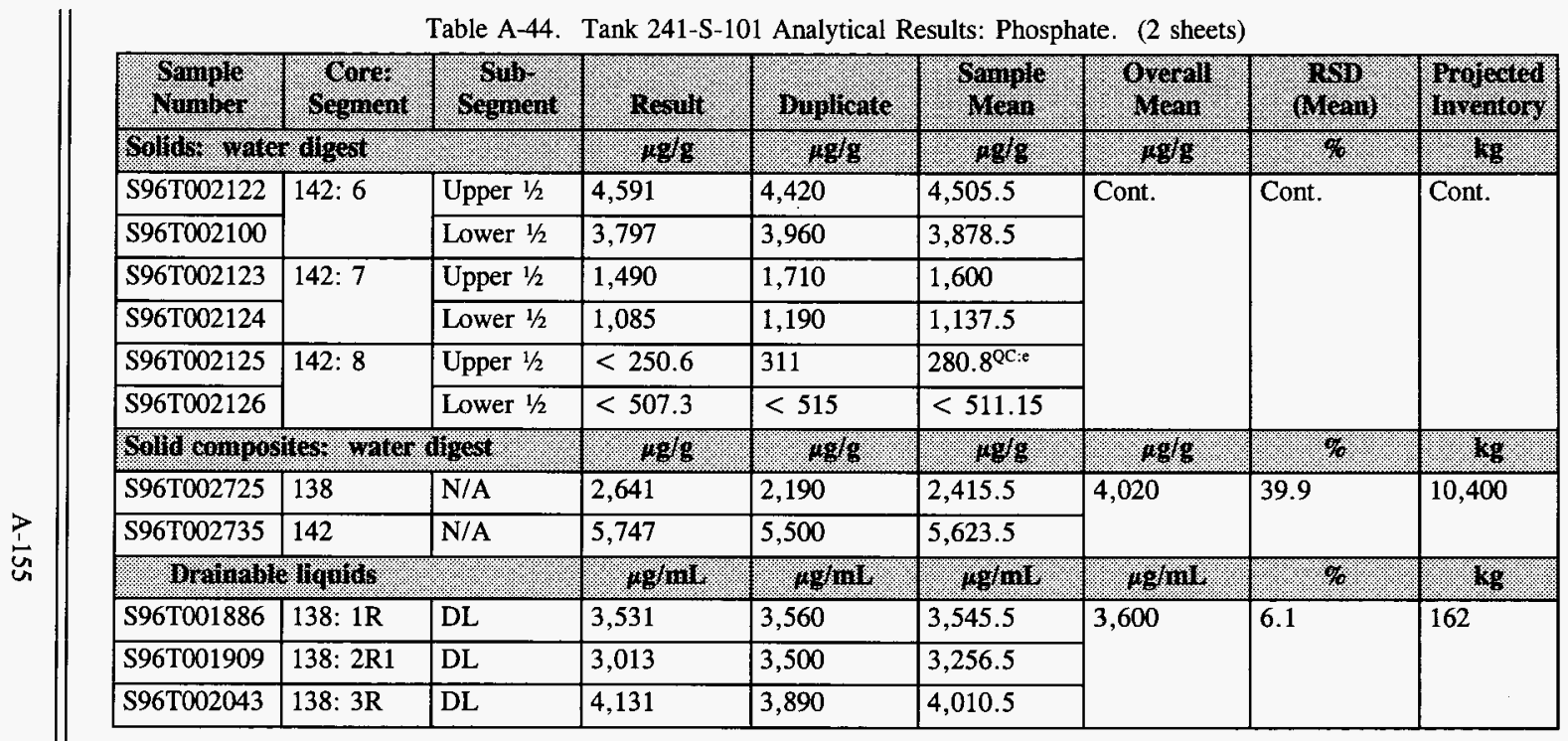


Table A-45. Tank 241-S-101 Analytical Results: Sulfate. (2 sheets)

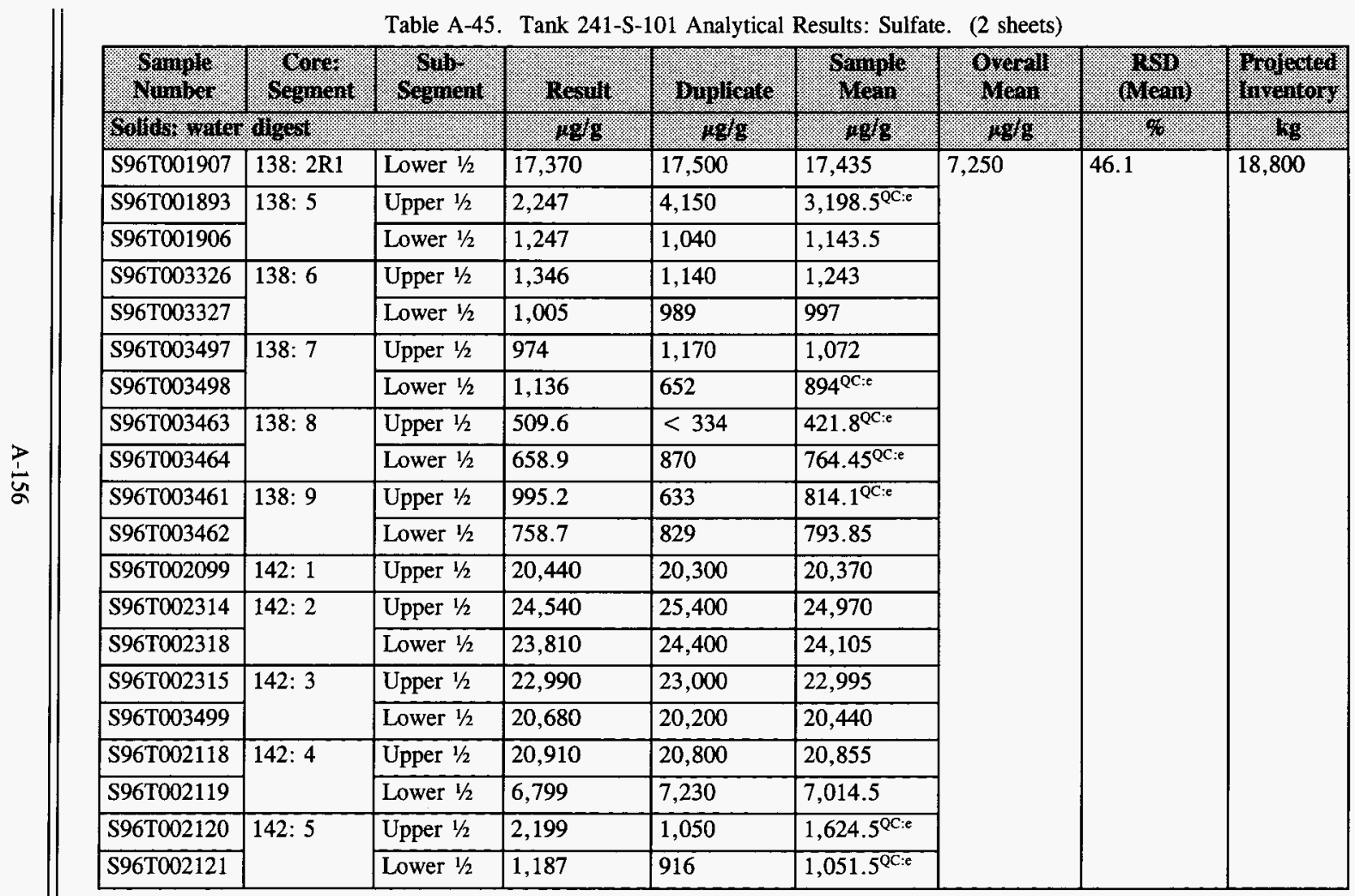


Table A-45. Tank 241-S-101 Analytical Results: Sulfate. (2 sheets)

\begin{tabular}{|c|c|c|c|c|c|c|c|c|}
\hline Somple & (1) & SoBmil & 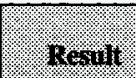 & 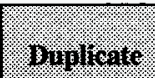 & Womp & orerill & 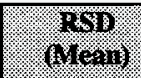 & movectod \\
\hline S96T002122 & \multirow[t]{2}{*}{$142: 6$} & Upper $1 / 2$ & 742.4 & 1,020 & $881.2^{\mathrm{QC}: \mathrm{e}}$ & \multirow[t]{4}{*}{ Cont. } & \multirow[t]{4}{*}{ Cont. } & \multirow[t]{4}{*}{ Cont. } \\
\hline \$96T002100 & & Lower $1 / 2$ & 1,362 & 1,330 & 1,346 & & & \\
\hline S96T002125 & \multirow[t]{2}{*}{ 142: 8} & Upper $1 / 2$ & 554.1 & 706 & $630.05^{\mathrm{QC}: e}$ & & & \\
\hline \$96T002126 & & Lower $1 / 2$ & 989.6 & 1,400 & $1,194.8^{\mathrm{QC}: \mathrm{e}}$ & & & \\
\hline \multicolumn{3}{|c|}{ 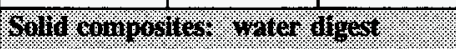 } & 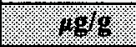 & 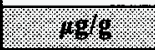 & 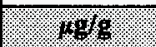 & $.09 \%$ &.$\%$ & (6. \\
\hline S96T002725 & 138 & N/A & 3,975 & 2,940 & $3,457.5^{Q \mathrm{QC} e}$ & 6,270 & 44.9 & 16,300 \\
\hline S96T001909 & 138: 2 R1 & DL & 5,130 & 6,290 & 5,710 & \multirow{2}{*}{5,650} & \multirow{2}{*}{4.6} & \multirow{2}{*}{254} \\
\hline S96T002043 & 138: $3 \mathrm{R}$ & DL & 6,051 & 6,090 & $6,070.5$ & & & \\
\hline
\end{tabular}


WHC-SD-WM-ER-613 Rev. 0

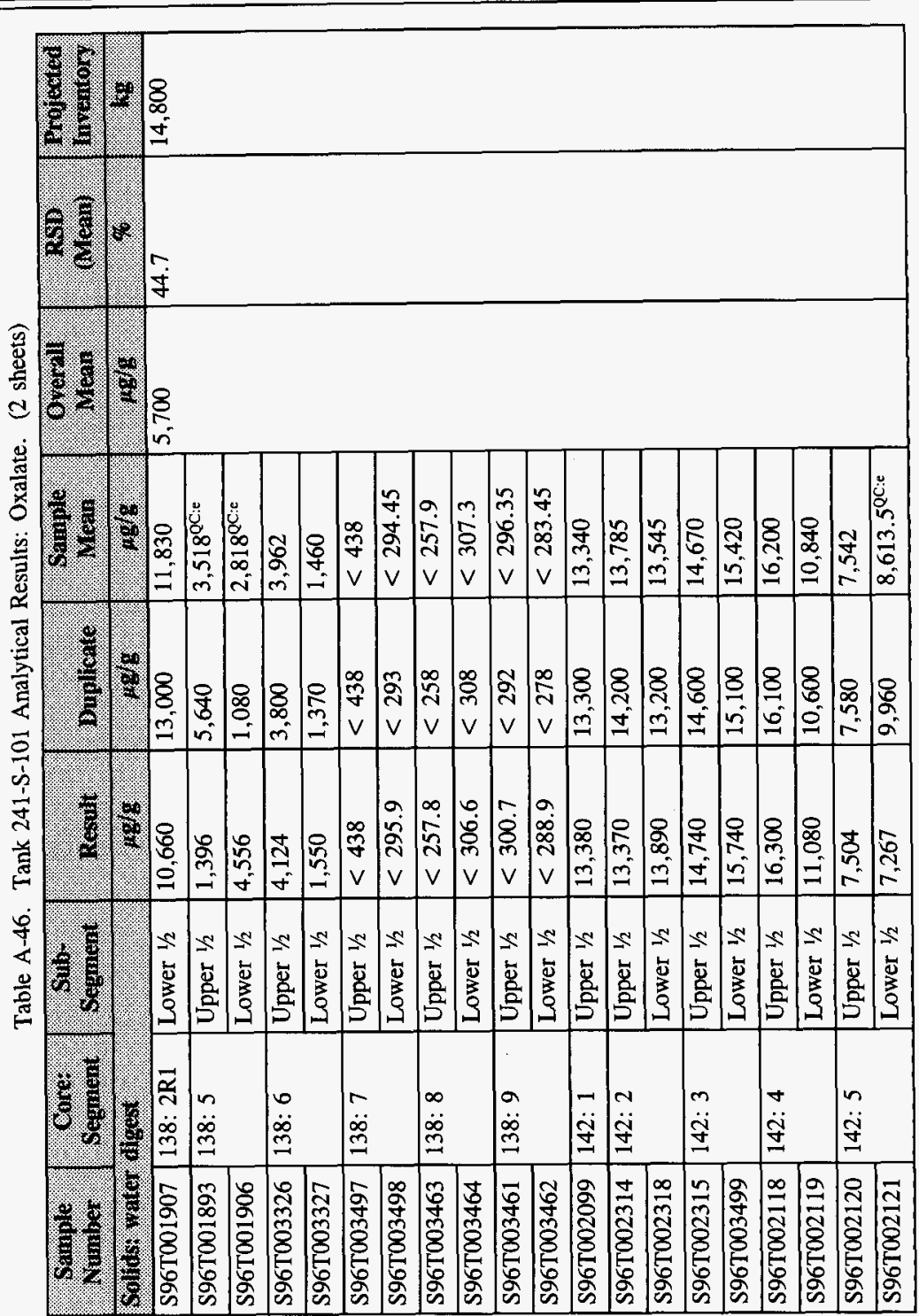


Table A-46. Tank 241-S-101 Analytical Results: Oxalate. (2 sheets)

\begin{tabular}{|c|c|c|c|c|c|c|c|c|}
\hline Wanolo & Worts & Sepnitert & 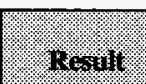 & Diplicats? & Monolo & Orofull & $\frac{6113}{619+11}$ & 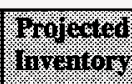 \\
\hline S96T002122 & \multirow[t]{2}{*}{$142: 6$} & Upper $1 / 2$ & 1,858 & 1,640 & 1,749 & \multirow[t]{4}{*}{ Cont. } & \multirow[t]{4}{*}{ Cont. } & \multirow[t]{4}{*}{ Cont. } \\
\hline S96T002100 & & Lower $1 / 2$ & 1,007 & 898 & 952.5 & & & \\
\hline S96T002125 & \multirow[t]{2}{*}{ 142: 8} & Upper $1 / 2$ & $<221.3$ & $<214$ & $<217.65$ & & & \\
\hline S96T002126 & & Lower $1 / 2$ & $<448$ & 2,300 & $1,374^{\mathrm{QC}: e}$ & & & \\
\hline \multicolumn{3}{|c|}{ 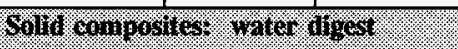 } & . 196 & 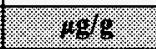 & . 196 & .196 & 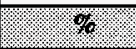 & \%.6. \\
\hline \$96T002725 & 138 & N/A & 1,386 & 1,320 & 1,353 & 3,940 & 65.7 & 10,200 \\
\hline \$96T001909 & 138: 2R1 & DL & $<1,071$ & $<1,070$ & $<1,070.5$ & \multirow{2}{*}{$<858$} & \multirow{2}{*}{ N/A } & \multirow{2}{*}{$<38.6$} \\
\hline S96T002043 & 138: $3 \mathrm{R}$ & $\overline{\mathrm{DL}}$ & $<434.8$ & $<435$ & $<434.9$ & & & \\
\hline
\end{tabular}


WHC-SD-WM-ER-613 Rev. 0

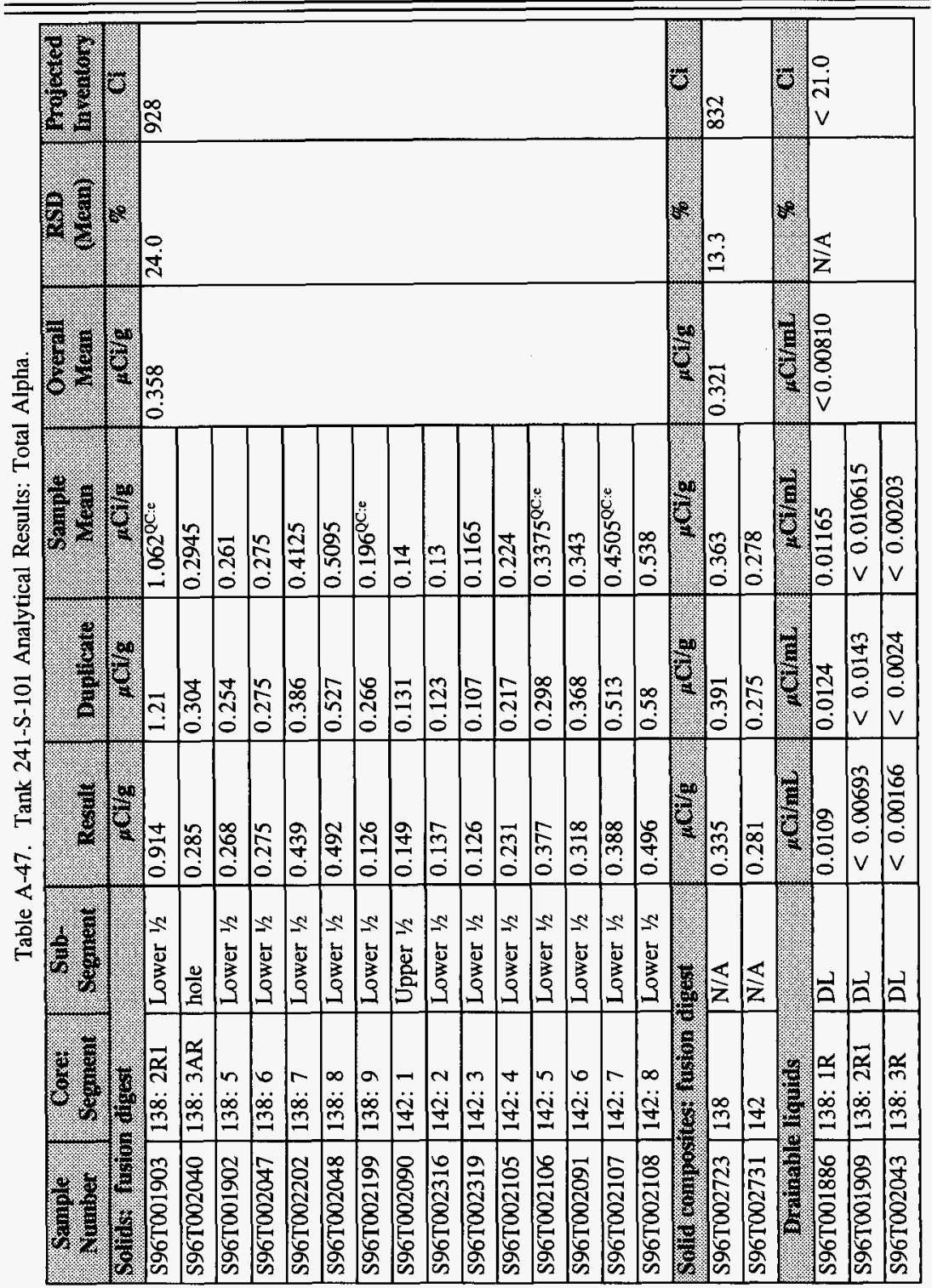




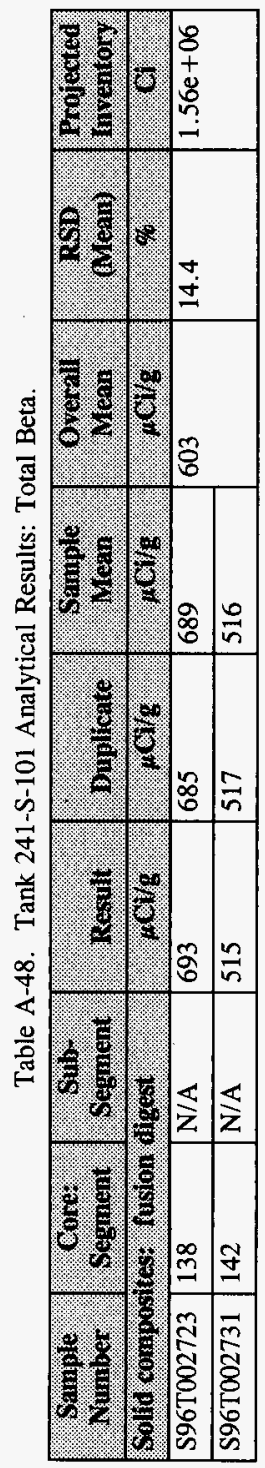




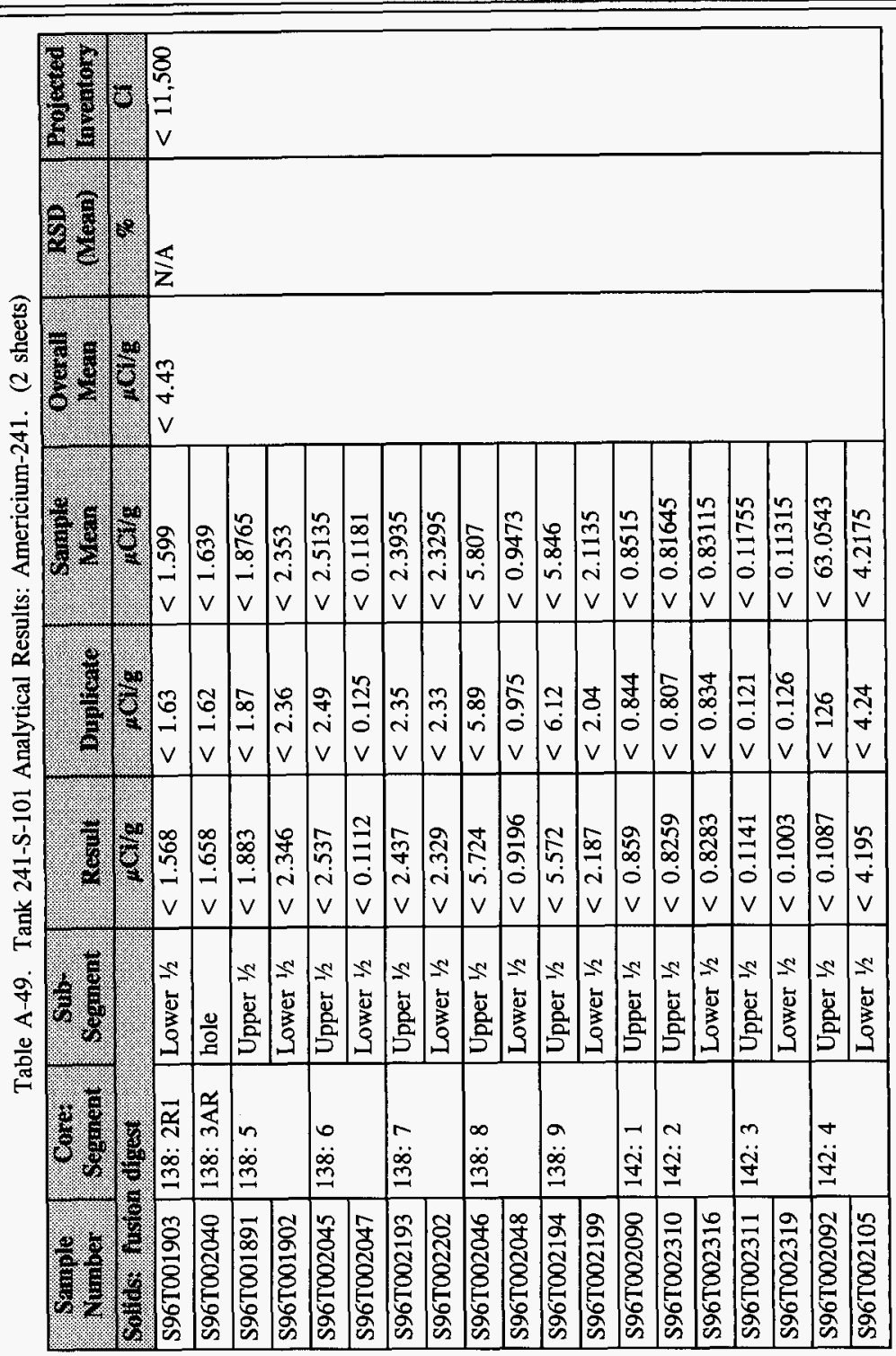


Table A-49. Tank 241-S-101 Analytical Results: Americium-241. (2 sheets)

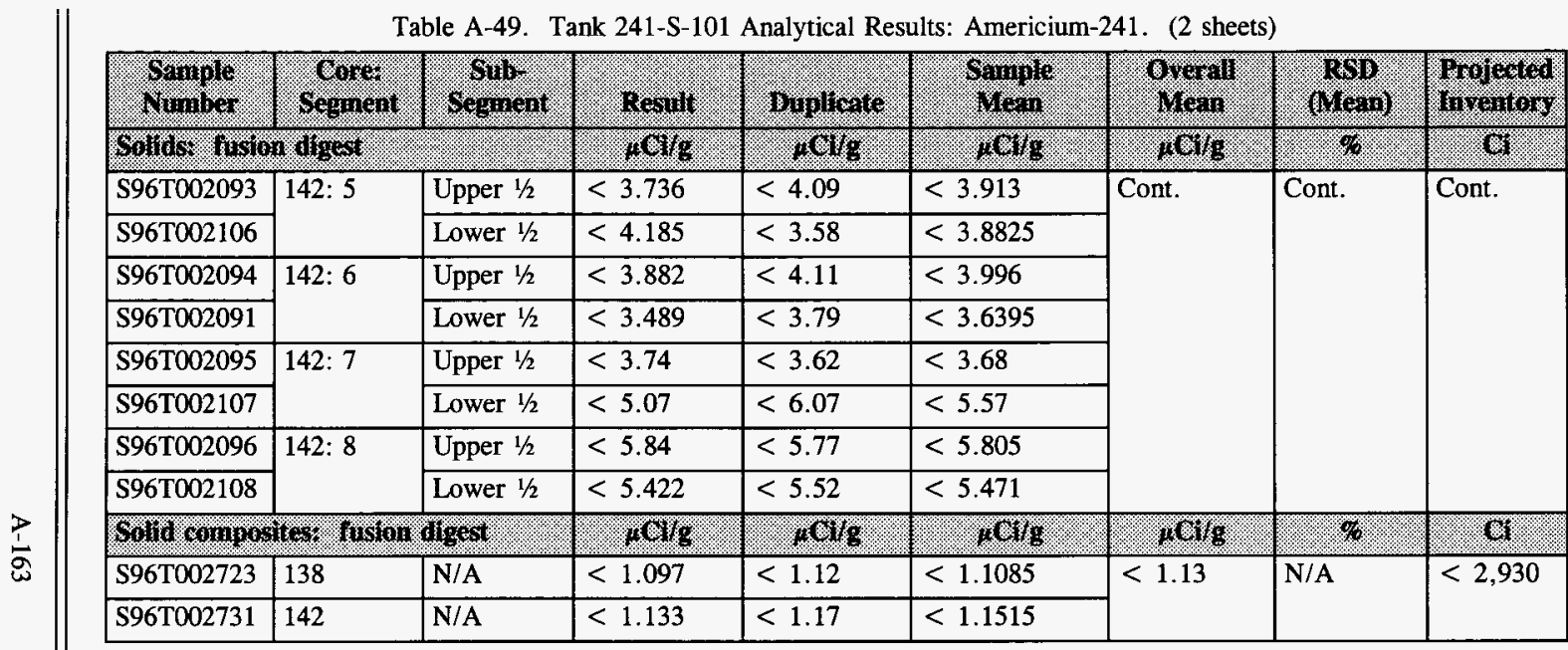


Table A-50. Tank 241-S-101 Analytical Results: Cesium-137. . (2 sheets)

\begin{tabular}{|c|c|c|c|c|c|c|c|c|}
\hline Gonplo & Sopricri & seprical & iesult & BHilong & Gomplo & Whorith & 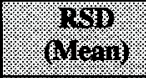 & Promedid \\
\hline \multicolumn{3}{|c|}{ 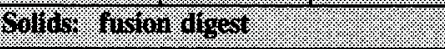 } & 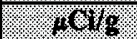 & 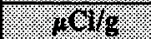 & 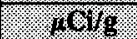 & 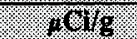 & S. & 1.7 .6 \\
\hline \$96T001903 & 138: 2R1 & Lower $1 / 2$ & 157.4 & 178 & 167.7 & \multirow[t]{21}{*}{131} & \multirow[t]{21}{*}{10.3} & \multirow[t]{21}{*}{$3.40 \mathrm{E}+05$} \\
\hline S96T002040 & 138: $3 \mathrm{AR}$ & hole & 117.7 & 118 & 117.85 & & & \\
\hline S96T001891 & \multirow[t]{2}{*}{ 138: 5} & Upper $1 / 2$ & 155.8 & 160 & 157.9 & & & \\
\hline S96T001902 & & Lower $1 / 2$ & 138.9 & 141 & 139.95 & & & \\
\hline S96T002045 & \multirow[t]{2}{*}{ 138: 6} & Upper $1 / 2$ & 129.5 & 132 & 130.75 & & & \\
\hline S96T002047 & & Lower $1 / 2$ & 98.14 & 113 & 105.57 & & & \\
\hline S96T002193 & \multirow[t]{2}{*}{ 138: 7} & Upper $1 / 2$ & 110.7 & 111 & 110.85 & & & \\
\hline \$96T002202 & & Lower $1 / 2$ & 96.87 & 98.2 & 97.535 & & & \\
\hline S96T002046 & \multirow[t]{2}{*}{ 138: 8} & Upper $1 / 2$ & 89.11 & 90.1 & 89.605 & & & \\
\hline S96T002048 & & Lower $1 / 2$ & 80.72 & 83.6 & 82.16 & & & \\
\hline S96T002194 & \multirow[t]{2}{*}{$138: 9$} & Upper $1 / 2$ & 77.54 & 78.9 & 78.22 & & & \\
\hline S96T002199 & & Lower $1 / 2$ & 71.61 & 70.9 & 71.255 & & & \\
\hline S96T002090 & 142: 1 & Upper $1 / 2$ & 176.5 & 176 & 176.25 & & & \\
\hline S96T002310 & \multirow[t]{2}{*}{ 142: 2} & Upper 1/2 & 175.7 & 173 & 174.35 & & & \\
\hline S96T002316 & & Lower $1 / 2$ & 171 & 167 & 169 & & & \\
\hline S96T002311 & \multirow[t]{2}{*}{ 142: 3} & Upper $1 / 2$ & 179.6 & 183 & 181.3 & & & \\
\hline S96T002319 & & Lower $1 / 2$ & 188.7 & 191 & 189.85 & & & \\
\hline S96T002092 & \multirow[t]{2}{*}{ 142: 4} & Upper $1 / 2$ & 174 & 173 & 173.5 & & & \\
\hline S96T002105 & & Lower $1 / 2$ & 172.3 & 167 & 169.65 & & & \\
\hline S96T002093 & \multirow[t]{2}{*}{$142: 5$} & Upper $1 / 2$ & 145.4 & 149 & 147.2 & & & \\
\hline S96T002106 & & Lower $1 / 2$ & 139.6 & 123 & 131.3 & & & \\
\hline
\end{tabular}


Table A-50. Tank 241-S-101 Analytical Results: Cesium-137. . (2 sheets)

\begin{tabular}{|c|c|c|c|c|c|c|c|c|}
\hline 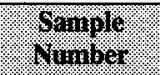 & Soprot & 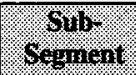 & Rerul! & 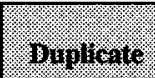 & 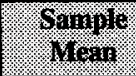 & Whonil. & (1) & 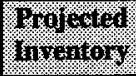 \\
\hline \multicolumn{3}{|c|}{ 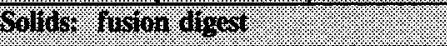 } & 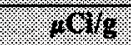 & 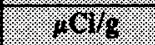 & 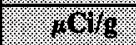 & Wo & $1 \% 1 \%$. & 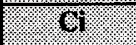 \\
\hline S96T002094 & 142: 6 & Upper $1 / 2$ & 132 & 133 & 132.5 & \multirow[t]{6}{*}{ Cont. } & \multirow[t]{6}{*}{ Cont. } & \multirow[t]{6}{*}{ Cont. } \\
\hline S96T002091 & & Lower $1 / 2$ & 103.6 & 118 & 110.8 & & & \\
\hline S96T002095 & \multirow[t]{2}{*}{$142: 7$} & Upper $1 / 2$ & 103.7 & 107 & 105.35 & & & \\
\hline S96T002107 & & Lower $1 / 2$ & $61 . \overline{74}$ & 116 & $88.87^{\mathrm{QC}: e}$ & & & \\
\hline S96T002096 & \multirow[t]{2}{*}{$142: 8$} & Upper $1 / 2$ & 97.52 & 75.4 & $86.46^{\mathrm{QC}: e}$ & & & \\
\hline S96T002108 & & Lower $1 / 2$ & 90.6 & 76.9 & 83.75 & & & \\
\hline \multicolumn{3}{|c|}{ 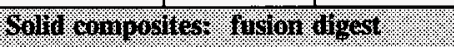 } & NGWE & $11 \mathrm{CH}_{\mathrm{g}}$ & .010 & $110 \%$ & $8 \%$ & \% \\
\hline S96T002723 & 138 & N/A & 115.3 & 120 & 117.65 & \multirow[t]{2}{*}{134} & \multirow[t]{2}{*}{12.2} & \multirow[t]{2}{*}{$3.47 \mathrm{E}+05$} \\
\hline S96T002731 & 142 & N/A & 148.8 & 152 & 150.4 & & & \\
\hline
\end{tabular}


Table A-51. Tank 241-S-101 Analytical Results: Cobalt-60. (2 sheets)

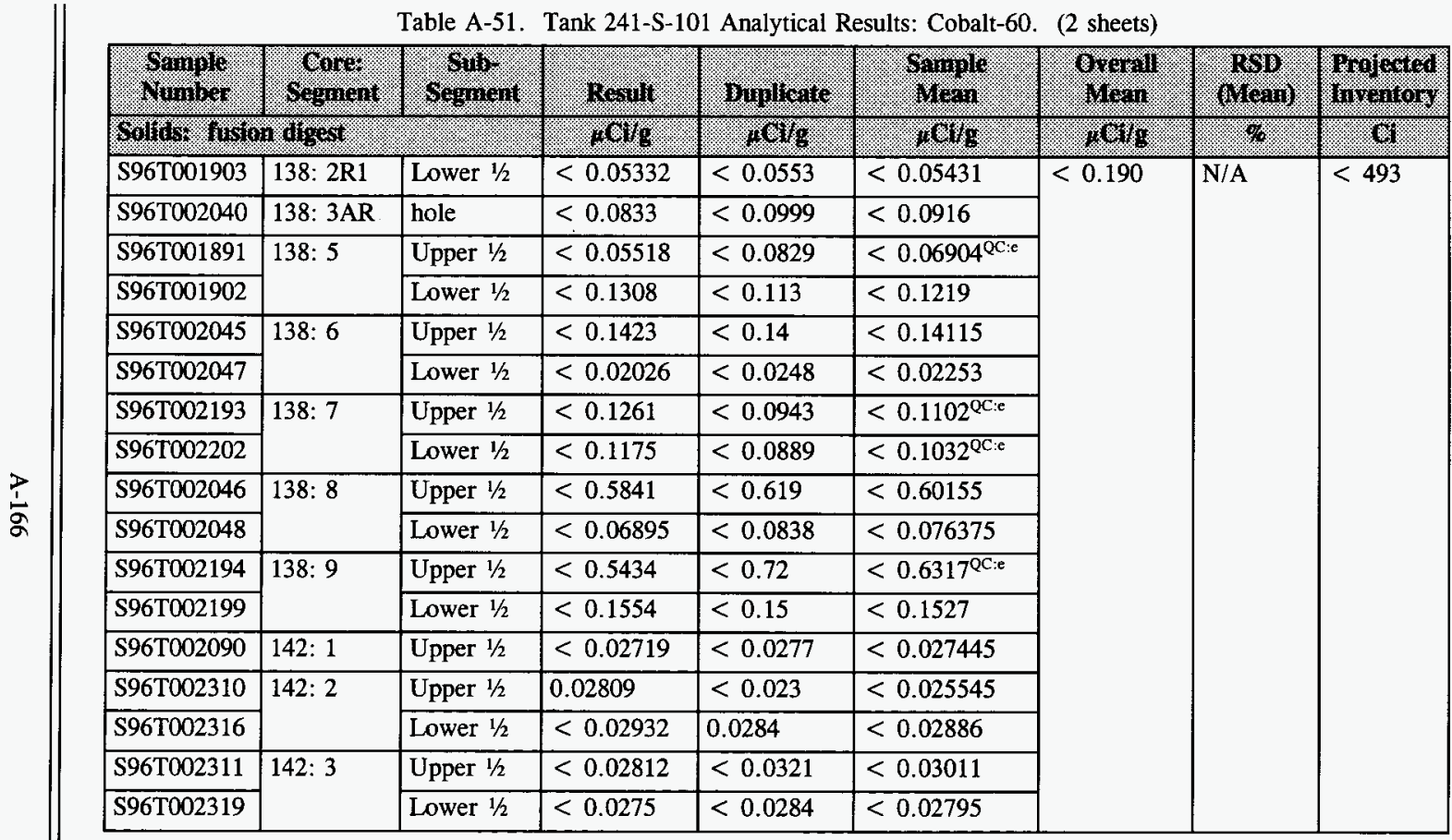


Table A-51. Tank 241-S-101 Analytical Results: Cobalt-60. (2 sheets)

\begin{tabular}{|c|c|c|c|c|c|c|c|c|}
\hline Wainio & \%orrot. & Gepment & Meraiti: & Wiplease & 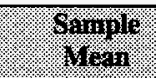 & $x_{1}+1$ & (1901) & morongrod \\
\hline \multicolumn{3}{|c|}{ Solost momoligest } & $140 \%$ & 19. & (1. & 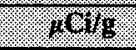 & (1) & 1.9 \\
\hline S96T002092 & \multirow[t]{2}{*}{$142: 4$} & Upper $1 / 2$ & 0.03844 & $<0.033$ & $<0.03572$ & \multirow[t]{6}{*}{ Cont. } & \multirow[t]{6}{*}{ Cont. } & \multirow[t]{6}{*}{ Cont. } \\
\hline S96T002105 & & Lower $1 / 2$ & $<0.3729$ & $<0.31$ & $<0.34145$ & & & \\
\hline S96T002094 & \multirow[t]{2}{*}{ 142: 6} & Upper $1 / 2$ & $<0.2526$ & $<0.25$ & $<0.2513$ & & & \\
\hline S96T002091 & & Lower $1 / 2$ & $<0.2361$ & $<0.256$ & $<0.24605$ & & & \\
\hline S96T002095 & \multirow[t]{2}{*}{ 142: 7} & Upper $1 / 2$ & $<0.2892$ & $<0.26$ & $<0.2746$ & & & \\
\hline S96T002107 & & Lower $1 / 2$ & $<0.4906$ & $<0.555$ & $<0.5228$ & & & \\
\hline S96T002723 & 138 & N/A & $<0.03353$ & $<0.0321$ & $<0.032815$ & \multirow[t]{2}{*}{$<0.0323$} & \multirow[t]{2}{*}{ N/A } & \multirow[t]{2}{*}{$<83.7$} \\
\hline S96T002731 & 142 & N/A & $<0.03168$ & $<0.0319$ & $<0.03179$ & & & \\
\hline
\end{tabular}


Table A-51. Tank 241-S-101 Analytical Results: Europium-154. (2 sheets)

\begin{tabular}{|c|c|c|c|c|c|c|c|c|}
\hline Somper & Sorrary & \%ollo & Mesill & bublicalo. & 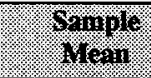 & Hesill & (1) & Horofor \\
\hline S96T001903 & 138: 2R1 & Lower $1 / 2$ & $<0.2271$ & $<0.175$ & $<0.20105$ & \multirow[t]{12}{*}{$<0.557$} & \multirow[t]{12}{*}{ N/A } & \multirow[t]{12}{*}{$<1,440$} \\
\hline S96T002040 & $138: \overline{\mathrm{AR}}$ & hole & $<0.3608$ & $<0.313$ & $<0.3369$ & & & \\
\hline S96T002045 & \multirow[t]{2}{*}{ 138: 6} & Upper $1 / 2$ & $<0.375$ & $<0.514$ & $<0.4445$ & & & \\
\hline S96T002047 & & Lower $1 / 2$ & $<0.1046$ & $<0.0904$ & $<0.0975$ & & & \\
\hline S96T002193 & \multirow[t]{2}{*}{ 138: 7} & Upper $1 / 2$ & $<0.5574$ & $<0.407$ & $<0.4822$ & & & \\
\hline S96T002202 & & Lower $1 / 2$ & $<0.4276$ & $<0.401$ & $<0.4143$ & & & \\
\hline S96T002199 & 138: 9 & Lower $1 / 2$ & $<0.3988$ & $<0.359$ & $<0.3789$ & & & \\
\hline S96T002090 & 142: 1 & Upper $1 / 2$ & $<0.1038$ & $<0.0964$ & $<0.1001$ & & & \\
\hline S96T002310 & \multirow[t]{2}{*}{ 142: 2} & Upper $1 / 2$ & $<0.107$ & $<0.11$ & $<0.1085$ & & & \\
\hline S96T002316 & & Lower $1 / 2$ & $<0.115$ & $<0.111$ & $<0.113$ & & & \\
\hline S96T002311 & \multirow[t]{2}{*}{ 142: 3} & Upper $1 / 2$ & $<0.1122$ & $<0.116$ & $<0.1141$ & & & \\
\hline S96T002319 & & Lower $1 / 2$ & $<0.1047$ & $<0.113$ & $<0.10885$ & & & \\
\hline
\end{tabular}


Table A-51. Tank 241-S-101 Analytical Results: Europium-154. (2 sheets)

\begin{tabular}{|c|c|c|c|c|c|c|c|c|}
\hline Momiale & ocminit & ofyment & Resull & Dyplicato & W. & $x_{10+11}$ & 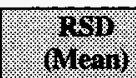 & 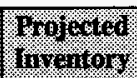 \\
\hline S96T002092 & 142: 4 & Upper $1 / 2$ & $<0.1121$ & $<0.124$ & $<0.11805$ & \multirow[t]{6}{*}{ Cont. } & \multirow[t]{6}{*}{ Cont. } & \multirow[t]{6}{*}{ Cont. } \\
\hline S96T002105 & & Lower $1 / 2$ & $<0.7253$ & $<1.12$ & $<0.92265$ & & & \\
\hline S96T002094 & \multirow[t]{2}{*}{$142: 6$} & Upper $1 / 2$ & $<0.7656$ & $<0.814$ & $<0.7898$ & & & \\
\hline \$96T002091 & & Lower $1 / 2$ & $<0.6298$ & $<0.812$ & $<0.7209$ & & & \\
\hline S96T002095 & \multirow[t]{2}{*}{$142: 7$} & Upper $1 / 2$ & $<0.7641$ & $<0.815$ & $<0.78955$ & & & \\
\hline S96T002107 & & Lower $1 / 2$ & $<1.98$ & $<1.65$ & $<1.815$ & & & \\
\hline S96T002723 & 138 & N/A & $<0.1268$ & $<0.158$ & $<0.1424$ & \multirow[t]{2}{*}{$<0.146$} & \multirow[t]{2}{*}{ N/A } & \multirow[t]{2}{*}{$<378$} \\
\hline S96T002731 & 142 & N/A & $<0.1433$ & $<0.154$ & $<0.14865$ & & & \\
\hline
\end{tabular}


Table A-52. Tank 241-S-101 Analytical Results: Europium-155. (2 sheets)

\begin{tabular}{|c|c|c|c|c|c|c|c|c|}
\hline Gomplo & Gopmer. & Sepment & Iresult & Buplicats? & o. & Orervil & 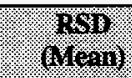 & Wrojtich \\
\hline \multicolumn{3}{|c|}{ 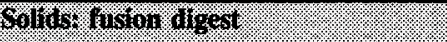 } & $.1 \%$ & $10 \%$ & 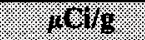 & 18 & 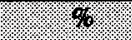 & (6. \\
\hline \$96T001903 & 138: $2 \mathrm{R} 1$ & Lower $1 / 2$ & $<0.6049$ & $<0.619$ & $<0.61195$ & \multirow[t]{21}{*}{$<1.06$} & \multirow[t]{21}{*}{ N/A } & \multirow[t]{21}{*}{$<2,750$} \\
\hline S96T002040 & 138: $3 \mathrm{AR}$ & hole & $<0.8007$ & $<0.752$ & $<0.77635$ & & & \\
\hline S96T001891 & \multirow[t]{2}{*}{$138: 5$} & Upper $1 / 2$ & $<0.7104$ & $<0.734$ & $<0.7222$ & & & \\
\hline S96T001902 & & Lower $1 / 2$ & $<0.9313$ & $<0.924$ & $<0.92765$ & & & \\
\hline S96T002045 & \multirow[t]{2}{*}{$138: 6$} & Upper $1 / 2$ & $<1.206$ & $<1.24$ & $<1.223$ & & & \\
\hline S96T002047 & & Lower $1 / 2$ & $<0.1975$ & $<0.2$ & $<0.19875$ & & & \\
\hline S96T002193 & \multirow[t]{2}{*}{$138: 7$} & Upper $1 / 2$ & $<0.9476$ & $<0.998$ & $<0.9728$ & & & \\
\hline \$96T002202 & & Lower $1 / 2$ & $<0.9537$ & $<0.926$ & $<0.93985$ & & & \\
\hline S96T002046 & \multirow[t]{2}{*}{ 138: 8} & Upper $1 / 2$ & $<2.344$ & $<2.29$ & $<2.317$ & & & \\
\hline S96T002048 & & Lower $1 / 2$ & $<0.4267$ & $<0.465$ & $<0.44585$ & & & \\
\hline S96T002194 & \multirow[t]{2}{*}{ 138: 9} & Upper $1 / 2$ & $<2.187$ & $<2.25$ & $<2.2185$ & & & \\
\hline S96T002199 & & Lower $1 / 2$ & $<0.8212$ & $<0.854$ & $<0.8376$ & & & \\
\hline S96T002090 & 142: 1 & Upper $1 / 2$ & $<0.4158$ & $<0.418$ & $<0.4169$ & & & \\
\hline S96T002310 & \multirow[t]{2}{*}{ 142: 2} & Upper $1 / 2$ & $<0.3959$ & $<0.388$ & $<0.39195$ & & & \\
\hline S96T002316 & & Lower $1 / 2$ & $<0.4046$ & $<0.4$ & $<0.4023$ & & & \\
\hline S96T002311 & \multirow[t]{2}{*}{$142: 3$} & Upper $1 / 2$ & $<0.2289$ & $<0.229$ & $<0.22895$ & & & \\
\hline S96T002319 & & Lower $1 / 2$ & $<0.2287$ & $<0.227$ & $<0.22785$ & & & \\
\hline S96T002092 & \multirow[t]{2}{*}{$142: 4$} & Upper $1 / 2$ & $<0.2265$ & $<0.224$ & $<0.22525$ & & & \\
\hline \$96T002105 & & Lower $1 / 2$ & $<2.098$ & $<2.09$ & $<2.094$ & & & \\
\hline \$96T002093 & \multirow[t]{2}{*}{$142: 5$} & Upper $1 / 2$ & $<1.835$ & $<1.93$ & $<1.8825$ & & & \\
\hline S96T002106 & & Lower $1 / 2$ & $<2.033$ & $<1.78$ & $<1.9065$ & & & \\
\hline
\end{tabular}


Table A-52. Tank 241-S-101 Analytical Results: Europium-155. (2 sheets)

\begin{tabular}{|c|c|c|c|c|c|c|c|c|}
\hline Simple & Goument & $\begin{array}{l}\text { Sinib } \\
\text { Segment }\end{array}$ & Result & Buplisate & $\begin{array}{c}\text { Sample } \\
\text { Mear }\end{array}$ & $\begin{array}{l}\text { Overall } \\
\text { Nean }\end{array}$ & $\begin{array}{l}\text { Rosis: } \\
\text { (Mean). }\end{array}$ & $\begin{array}{l}\text { Trolered } \\
\text { Inreatory }\end{array}$ \\
\hline \multicolumn{3}{|c|}{ Solfds W Wiron digest } & $10 \% \mathrm{~g}$ & 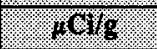 & 1918 & .1618 & \% & (I. \\
\hline S96T002094 & $142: 6$ & Upper $1 / 2$ & $<1.512$ & $<1.49$ & $<1.501$ & \multirow[t]{6}{*}{ Cont. } & \multirow[t]{6}{*}{ Cont. } & \multirow[t]{6}{*}{ Cont. } \\
\hline S96T002091 & & Lower $1 / 2$ & $<1.438$ & $<1.49$ & $<1.464$ & & & \\
\hline S96T002095 & \multirow[t]{2}{*}{$142: 7$} & Upper $1 / 2$ & $<1.459$ & $<1.51$ & $<1.4845$ & & & \\
\hline S96T002107 & & Lower $1 / 2$ & $<2.115$ & $<2.49$ & $<2.3025$ & & & \\
\hline S96T002096 & \multirow[t]{2}{*}{$142: 8$} & Upper $1 / 2$ & $<2.387$ & $<2.31$ & $<2.3485$ & & & \\
\hline S96T002108 & & Lower $1 / 2$ & $<2.283$ & $<2.16$ & $<2.2215$ & & & \\
\hline \multicolumn{3}{|c|}{ Solit composites: fision digest } & . $101 \mathrm{~g}$ & (2) CI/8 & .1018 & $13 \mathrm{mo}$ & . $\%$ & (1) \\
\hline S96T002723 & 138 & N/A & $<0.4165$ & $<0.431$ & $<0.42375$ & \multirow[t]{2}{*}{$<0.438$} & \multirow[t]{2}{*}{ N/A } & \multirow[t]{2}{*}{$<1,140$} \\
\hline S96T002731 & 142 & N/A & $<0.4473$ & $<0.457$ & $<0.45215$ & & & \\
\hline
\end{tabular}




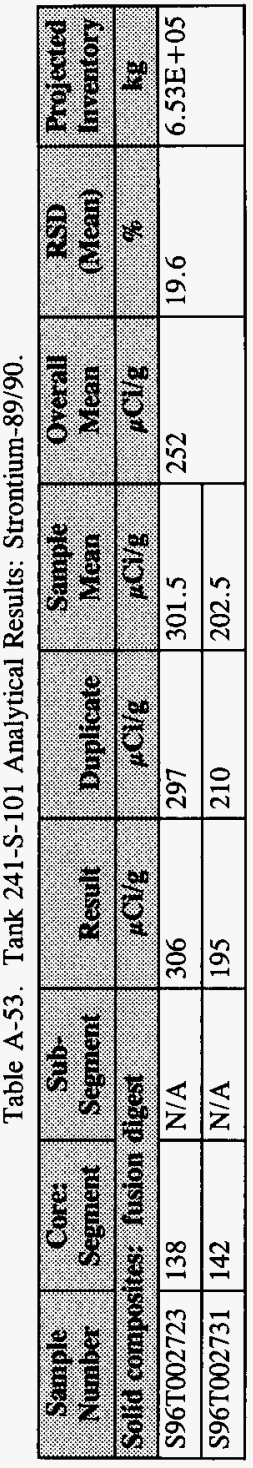


Table A-54. Tank 241-S-101 Analytical Results: Total inorganic carbon.

\begin{tabular}{|c|c|c|c|c|c|c|c|c|}
\hline $\begin{array}{l}\text { Sample } \\
\text { Nuniber }\end{array}$ & $\begin{array}{l}\text { Care: } \\
\text { Segrant }\end{array}$ & $\begin{array}{l}\text { Sulb } \\
\text { Se extrent }\end{array}$ & Resall & Digullcate & $\begin{array}{l}\text { Sampie } \\
\text { Mean }\end{array}$ & $\begin{array}{l}\text { Orerail } \\
\text { Near: }\end{array}$ & MSD & $\begin{array}{l}\text { Trojected } \\
\text { Inventory }\end{array}$ \\
\hline \multicolumn{3}{|c|}{ Solld composites } & $1487 \mathrm{~g}$ & 148/s & $190 / 8$ & rog/g & 8 & (63) \\
\hline S96T002721 & 138 & N/A & 1,640 & 1,500 & 1,570 & \multirow[t]{2}{*}{3,760} & \multirow[t]{2}{*}{58.3} & \multirow[t]{2}{*}{9,750} \\
\hline S96T002728 & 142 & N/A & 5,900 & 6,010 & 5,960 & & & \\
\hline
\end{tabular}

Table A-55. Tank 241-S-101 Analytical Results: Total organic carbon.

\begin{tabular}{|c|c|c|c|c|c|c|c|c|}
\hline $\begin{array}{l}\text { Sample } \\
\text { Yumber }\end{array}$ & $\begin{array}{l}\text { Cores } \\
\text { Segment }\end{array}$ & $\begin{array}{c}\text { Subs } \\
\text { Segment }\end{array}$ & Resull & Buplicate & $\begin{array}{l}\text { Sampie } \\
\text { Mean }\end{array}$ & $\begin{array}{l}\text { Orerall } \\
\text { Mean }\end{array}$ & $\begin{array}{c}\text { RSO } \\
\text { (Nean }\end{array}$ & $\begin{array}{l}\text { Projected } \\
\text { Inventory }\end{array}$ \\
\hline Solid oo inpo & Hes : & & og/g & 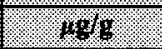 & 1098 & $1.4 \mathrm{~g} / \mathrm{g}$. & 1.9. & 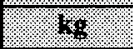 \\
\hline S96T002721 & 138 & N/A & 851 & 852 & 851.5 & \multirow[t]{2}{*}{1,990} & \multirow[t]{2}{*}{57.3} & \multirow[t]{2}{*}{5,160} \\
\hline S96T002728 & 142 & N/A & 3,100 & 3,170 & 3,135 & & & \\
\hline
\end{tabular}


Table A-56. Tank 241-S-101 Analytical Results: Differential Scanning Calorimetry. (4 sheets)

\begin{tabular}{|c|c|c|c|c|c|c|c|c|c|c|}
\hline \multirow{2}{*}{$\begin{array}{l}\text { Sample } \\
\text { riminer } \\
\text { Solus }\end{array}$} & \multirow{2}{*}{ Gegnent } & \multirow{2}{*}{ S Iorintion } & \multirow[t]{2}{*}{ Ran } & \multirow{2}{*}{ 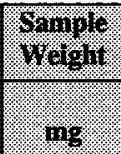 } & \multicolumn{2}{|c|}{ Transition ! } & \multicolumn{2}{|c|}{ Trangition 2} & \multicolumn{2}{|c|}{ Transition } \\
\hline & & & & & $\begin{array}{l}\text { Teak Terng } \\
(190)\end{array}$ & $\begin{array}{l}4 \pi \\
610\end{array}$ & 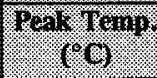 & $\begin{array}{l}\text { Aqu } \\
\text { (I/g) }\end{array}$ & $\begin{array}{l}\text { feall remor. } \\
\text { (a) }\end{array}$ & $\begin{array}{l}8,11 \\
(1 / 9)\end{array}$ \\
\hline \multirow[t]{2}{*}{ S96T001899 ${ }^{1}$} & \multirow[t]{2}{*}{ 138: 2R1 } & \multirow[t]{2}{*}{ Lower $1 / 2$} & 1 & 26.05 & 125 & 1,272 & - & -- & - & -- \\
\hline & & & 2 & 19.18 & 112 & 1,177 & 189 & 13.0 & - & -- \\
\hline \multirow[t]{2}{*}{ S96T002001 } & \multirow[t]{2}{*}{ 138: $3 \mathrm{AR}$} & \multirow[t]{2}{*}{ Whole } & 1 & 16.30 & 122 & 1,171 & -- & -- & - & -- \\
\hline & & & 2 & 18.08 & 127 & 1,092 & -- & -- & - & - \\
\hline \multirow[t]{2}{*}{ S96T001889' } & \multirow[t]{4}{*}{$138: 5$} & \multirow[t]{2}{*}{ Upper $1 / 2$} & 1 & 21.65 & 150 & 1,053 & -- & 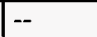 & - & -- \\
\hline & & & 2 & 22.94 & 130 & 1,362 & - & - & \begin{tabular}{|l|}
-- \\
\end{tabular} & - \\
\hline \multirow[t]{2}{*}{ S96T001898 } & & \multirow[t]{2}{*}{ Lower $1 / 2$} & 1 & 22.84 & 127 & 1,305 & - & - & - & -- \\
\hline & & & 2 & 23.32 & 130 & 1,288 & -- & -- & -- & -- \\
\hline \multirow[t]{2}{*}{ S96T001958 } & \multirow[t]{4}{*}{ 138: 6} & \multirow[t]{2}{*}{ Upper $1 / 2$} & 1 & 11.36 & 114 & 831.9 & 184 & 84.0 & 333 & 23.0 \\
\hline & & & 2 & 12.64 & 123 & 1645 & 249 & 10.0 & -- & -- \\
\hline \multirow[t]{2}{*}{ S96T001959¹ } & & \multirow[t]{2}{*}{ Lower $1 / 2$} & 1 & 23.01 & 123 & 902.3 & 238 & 9.0 & - & - \\
\hline & & & 2 & 11.65 & 102 & 814.0 & 251 & 56.6 & - & -- \\
\hline \multirow[t]{2}{*}{ S96T002167 } & \multirow[t]{2}{*}{ 138: 7} & \multirow[t]{2}{*}{ Upper $1 / 2$} & 1 & 46.38 & 163 & 944.3 & -- & - & -- & - \\
\hline & & & 2 & 60.02 & 165 & 864.4 & -- & -- & - & - \\
\hline \multirow[t]{2}{*}{ S96T002166 } & \multirow[t]{2}{*}{$138: 7$} & \multirow[t]{2}{*}{ Lower $1 / 2$} & 1 & 26.62 & 163 & 826.5 & -- & -- & -- & - \\
\hline & & & 2 & 28.33 & 164 & 861.0 & -- & -- & -- & - \\
\hline \multirow[t]{2}{*}{ S96T002004 ${ }^{1}$} & \multirow[t]{4}{*}{$138: 8$} & \multirow[t]{2}{*}{ Upper $1 / 2$} & 1 & 22.61 & 133 & 676.4 & 271 & 8.5 & -- & - \\
\hline & & & 2 & 33.30 & 139 & 739.7 & 265 & 6.2 & - & - \\
\hline S96T002005 & & Lower $1 / 2$ & 1 & 47.72 & 138 & 507.9 & 210 & 69.4 & - & -- \\
\hline & & & 2 & 31.11 & 138 & 560.7 & 215 & 72.5 & -- & - \\
\hline
\end{tabular}




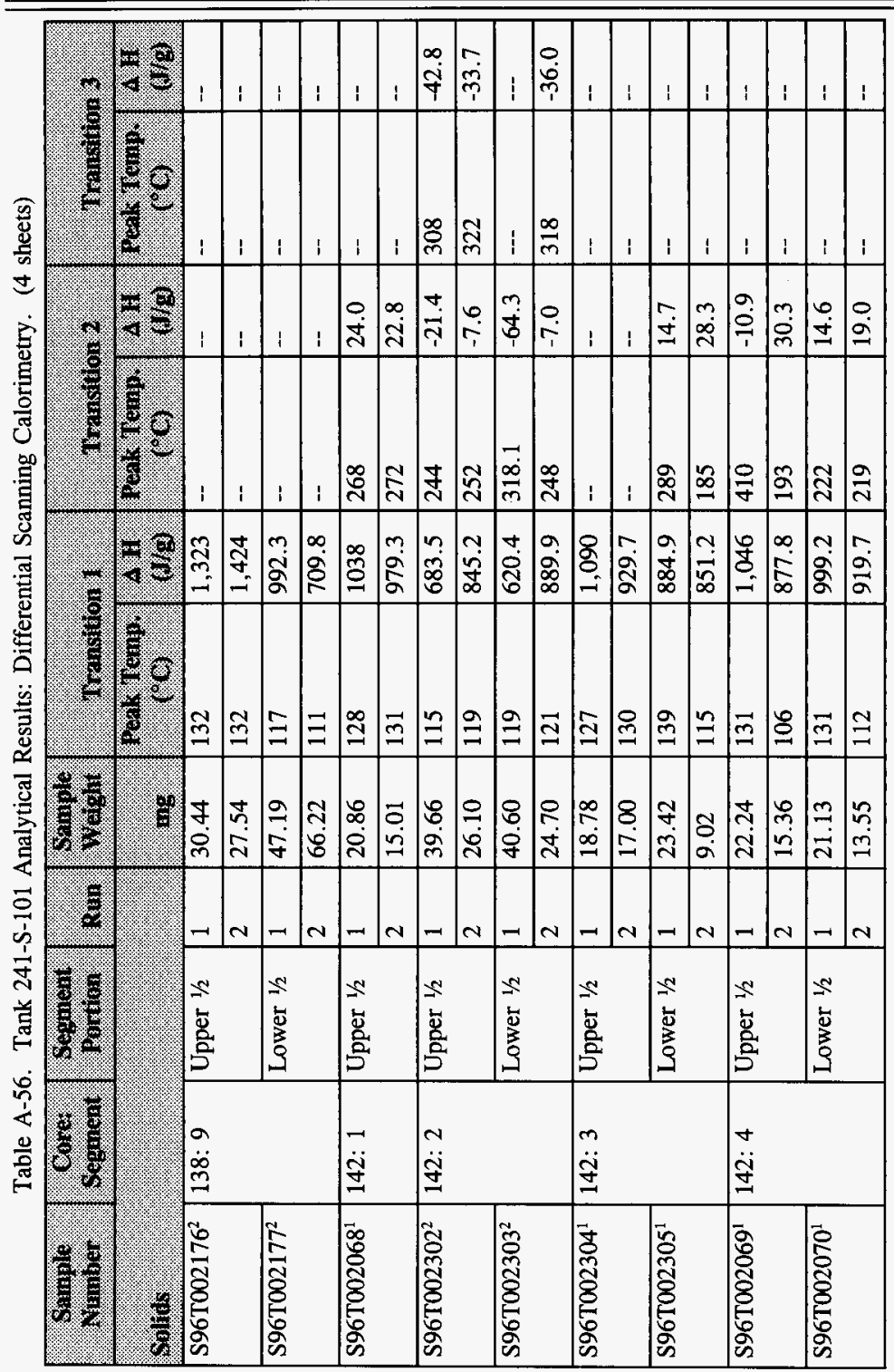




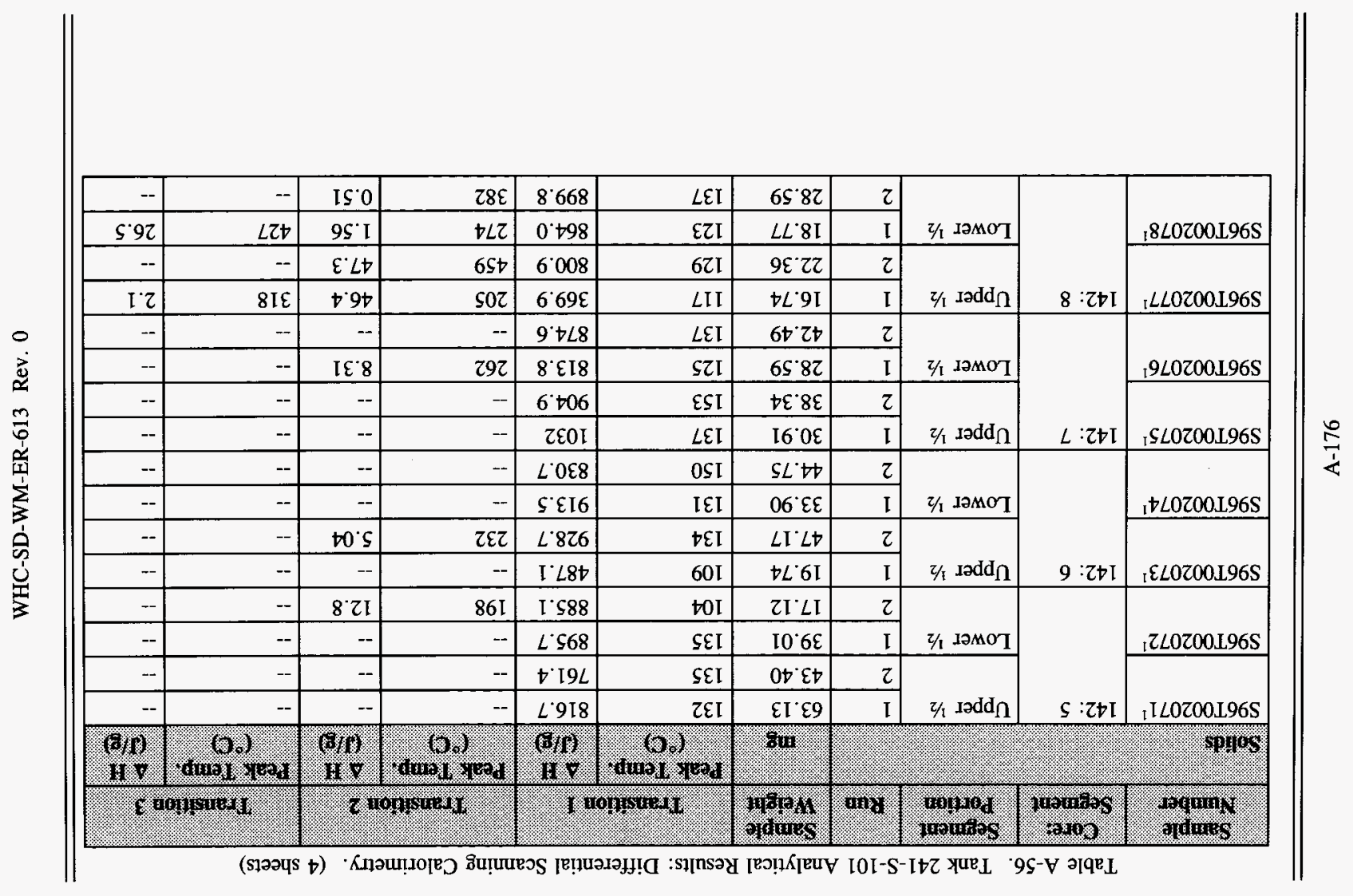




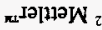

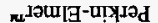

:S210N

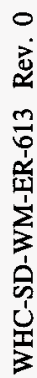

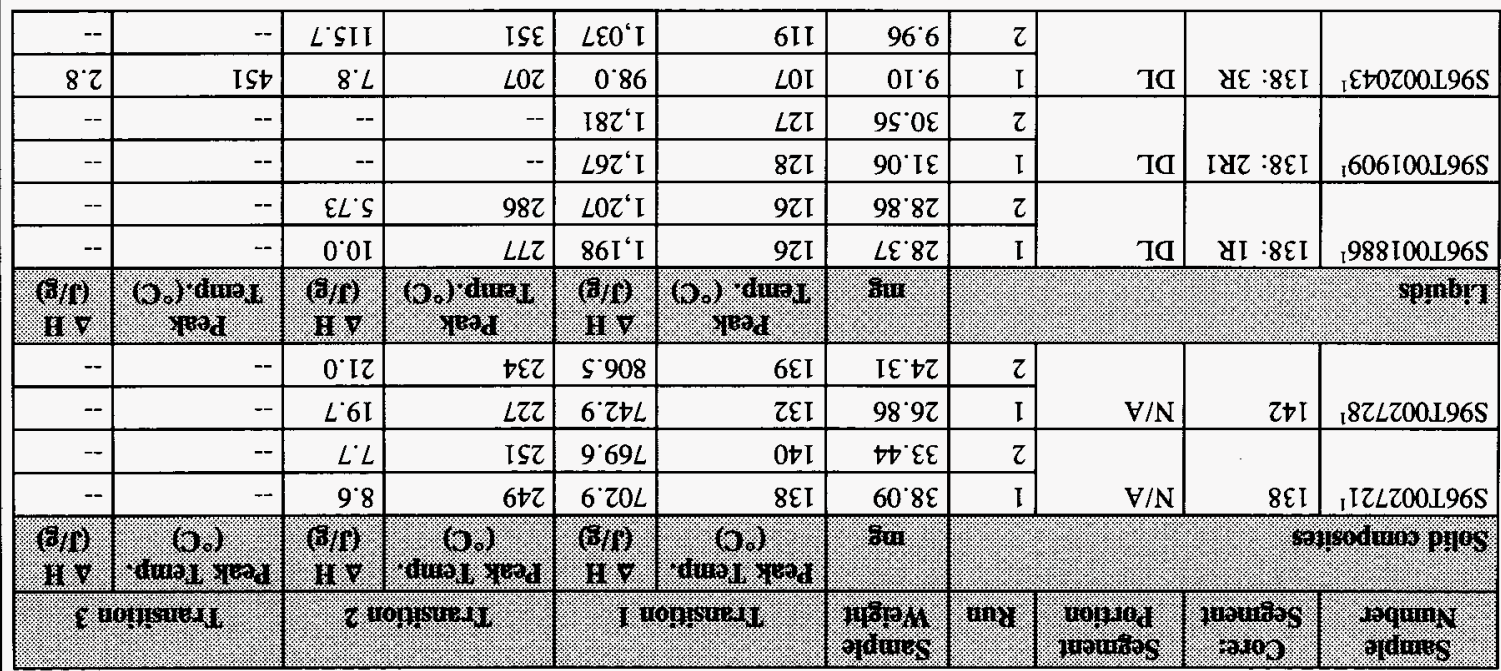

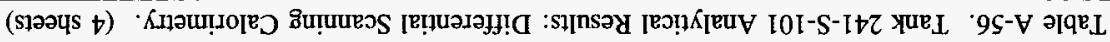




\begin{tabular}{|c|c|c|c|c|c|c|c|c|c|}
\hline (4) & 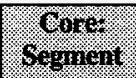 & 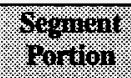 & \multicolumn{2}{|c|}{ Mesulit } & \multicolumn{2}{|c|}{ iminluate } & Whingly & Wholl & 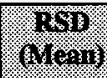 \\
\hline \multicolumn{3}{|l|}{ worlins. } & \% \% & panger. & $6 \%$ & Mamprar & W. & $1 \% 1 \%$ & (6) \\
\hline S96T001899 1 & 138: 2R1 & Lower $1 / 2$ & 52.18 & $40-190$ & 52.57 & $40-190$ & 52.375 & \multirow[t]{16}{*}{40.2} & \multirow[t]{16}{*}{3.5} \\
\hline S96T002001 ${ }^{2}$ & 138: $3 \mathrm{AR}$ & Whole & 46.52 & $35-220$ & 43.86 & $35-200$ & 45.19 & & \\
\hline S96T001889 & \multirow[t]{2}{*}{$138: 5$} & Upper $1 / 2$ & 48.8 & $26-250$ & 49.14 & $24-250$ & 48.97 & & \\
\hline S96T001898 & & Lower $1 / 2$ & 39.07 & $28-220$ & 38.84 & $22-210$ & 38.955 & & \\
\hline S96T001958 & \multirow[t]{4}{*}{$138: 6$} & Upper $1 / 2$ & 23.21 & N/A & 38.67 & N/A & $30.94^{\mathrm{OC}: \mathrm{e}}$ & & \\
\hline S96T001958 & & Upper $1 / 2$ & 38.84 & $35-250$ & 39.54 & $35-250$ & 39.19 & & \\
\hline S96T0019592 & & Lower $1 / 2$ & 68.84 & N/A & 37.11 & N/A & $52.975^{\mathrm{QC}: \mathrm{e}}$ & & \\
\hline S96T0019592 & & Lower $1 / 2$ & 36.38 & $35-250$ & 36.81 & $35-240$ & 36.595 & & \\
\hline S96T0021672 & \multirow[t]{2}{*}{ 138: 7} & Upper $1 / 2$ & 38.19 & $20-250$ & 37.49 & $35-250$ & 37.84 & & \\
\hline S96T002166 & & Lower $1 / 2$ & 32.36 & $26-270$ & 30.46 & $30-270$ & 31.41 & & \\
\hline S96T0020042 & \multirow[t]{2}{*}{ 138: 8} & Upper $1 / 2$ & 35.13 & $35-280$ & 35.34 & $35-260$ & 35.235 & & \\
\hline S96T002005 2 & & Lower $1 / 2$ & 33.32 & $35-260$ & 34.18 & $35-260$ & 33.75 & & \\
\hline \multirow[t]{2}{*}{ S96T002176 } & \multirow[t]{3}{*}{$138: 9$} & Upper $1 / 2$ & 28.35 & $40-280$ & 33.54 & $40-260$ & \multirow[t]{2}{*}{$30.945^{\mathrm{QC}: \mathrm{e}}$} & & \\
\hline & & & \multicolumn{2}{|l|}{ triplicate } & 32.84 & $40-260$ & & & \\
\hline S96T002177 & & Lower $1 / 2$ & 35.58 & $40-240$ & 33.54 & $40-240$ & 34.56 & & \\
\hline S96T002068 2 & 142: 1 & Upper $1 / 2$ & 44.65 & $31-200$ & $\overline{44.6}$ & $21-210$ & 44.625 & & \\
\hline
\end{tabular}


Table A-57. Tank 241-S-101 Analytical Results: Weight Percent Water. (3 sheets)

\begin{tabular}{|c|c|c|c|c|c|c|c|c|c|}
\hline Warnof & 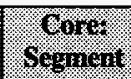 & 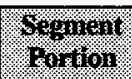 & \multicolumn{2}{|r|}{ resuil: } & \multicolumn{2}{|c|}{ Mayrileato. } & oimulo & Whall & \multirow{2}{*}{ 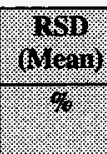 } \\
\hline $9016 \%$ & & & 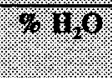 & Waming ware & 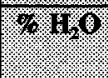 & 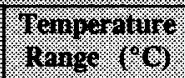 & $\%$ & \% $1 \%$ & \\
\hline S96T002302 & \multirow[t]{2}{*}{ 142: 2} & Upper $1 / 2$ & 45.23 & $40-180$ & 44.08 & $40-170$ & 44.655 & \multirow[t]{15}{*}{ Cont. } & \multirow[t]{15}{*}{ Cont. } \\
\hline S96T002303 $^{1}$ & & Lower $1 / 2$ & 43.31 & $40-170$ & 42.27 & $40-160$ & 42.79 & & \\
\hline S96T002304² & \multirow[t]{2}{*}{ 142: 3} & Upper $1 / 2$ & 40.52 & $22-190$ & 42.38 & $21-210$ & 41.525 & & \\
\hline S96T002305 & & Lower $1 / 2$ & 40.5 & $35-190$ & 41.55 & $35-210$ & 40.95 & & \\
\hline S96T002069 & \multirow[t]{2}{*}{ 142: 4} & Upper $1 / 2$ & 39.9 & $20-210$ & 40.2 & $21-220$ & 40.05 & & \\
\hline S96T002070 & & Lower $1 / 2$ & 41.15 & $23-220$ & 40.88 & $21-210$ & 41.015 & & \\
\hline S96T0020712 & \multirow[t]{2}{*}{$142: 5$} & Upper $1 / 2$ & 48.32 & $22-250$ & 47.77 & $20-250$ & $48: 045$ & & \\
\hline S96T0020722 & & Lower $1 / 2$ & 44.34 & $20-230$ & 37.09 & $20-240$ & 40.715 & & \\
\hline S96T002073 & \multirow[t]{2}{*}{ 142: 6} & Upper $1 / 2$ & 38.87 & $21-230$ & 41.22 & $21-220$ & 40.045 & & \\
\hline S96T0020742 & & Lower $1 / 2$ & 37.42 & $20-250$ & 35.97 & $30-250$ & 36.695 & & \\
\hline S96T002075 & \multirow[t]{3}{*}{ 142: 7} & Upper $1 / 2$ & 37.23 & $35-250$ & 20.74 & $35-260$ & $28.985^{\mathrm{QC}: \mathrm{e}}$ & & \\
\hline S96T002075 & & Upper $1 / 2$ & 42.79 & $35-200$ & 41.1 & $23-200$ & 41.945 & & \\
\hline S96T002076 & & Lower $1 / 2$ & 36.99 & $35-250$ & 36.14 & $35-260$ & 36.565 & & \\
\hline S96T002077 & \multirow[t]{2}{*}{$142: 8$} & Upper $1 / 2$ & 29.25 & $20-260$ & 27.86 & $21-250$ & 28.555 & & \\
\hline S96T0020782 & & Lower $1 / 2$ & 33.74 & $22-280$ & 32.27 & $26-260$ & 33.005 & & \\
\hline
\end{tabular}


Table A-57. Tank 241-S-101 Analytical Results: Weight Percent Water. (3 sheets)

\begin{tabular}{|c|c|c|c|c|c|c|c|c|c|}
\hline \multirow{2}{*}{ 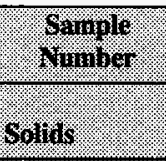 } & \multirow[t]{2}{*}{ Worro } & \multirow{2}{*}{ 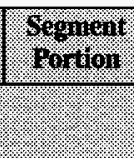 } & \multicolumn{2}{|r|}{ Resuli } & \multicolumn{2}{|c|}{ inanterto } & \multirow{2}{*}{ 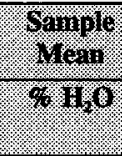 } & \multirow{2}{*}{ 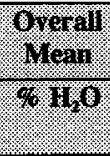 } & \multirow{2}{*}{$\frac{(6.910}{6 \%}$} \\
\hline & & & 6\% $1 \%$ & 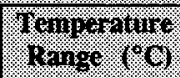 & $1 \% 1 \%$ & Wenpequral & & & \\
\hline \multicolumn{10}{|c|}{ bouq couposims. } \\
\hline S96T002721 ${ }^{1}$ & 138 & Whole & 34.76 & $40-240$ & 36.2 & $40-240$ & 35.48 & \multirow[t]{3}{*}{38.4} & \multirow[t]{3}{*}{7.5} \\
\hline \multirow[t]{2}{*}{ S96T002728 ${ }^{1}$} & \multirow[t]{2}{*}{$\overline{142}$} & \multirow[t]{2}{*}{ Whole } & 45.59 & $40-220$ & 37.13 & $40-180$ & \multirow[t]{2}{*}{$41.24^{\mathrm{QC}: \mathrm{e}}$} & & \\
\hline & & & triplicate & & 41.0 & $40-200$ & & & \\
\hline \multicolumn{10}{|l|}{ Winiol } \\
\hline S96T001886 & 138: $1 \mathrm{R}$ & DL & 53.69 & $24-230$ & 53.71 & $24-230$ & 53.7 & \multirow[t]{3}{*}{53.1} & \multirow[t]{3}{*}{1.0} \\
\hline S96T001909² & 138: 2R1 & $\mathrm{DL}$ & 51.71 & $35-230$ & 52.46 & $35-230$ & 52.085 & & \\
\hline S96T0020432 & 138: 3R & DL & 53.76 & $22-240$ & 53.42 & $21-230$ & 53.59 & & \\
\hline \multicolumn{10}{|c|}{$\begin{array}{l}\text { Notes: } \\
{ }^{\mathrm{l}} \text { Mettler }{ }^{\mathrm{Tx}} \\
{ }^{2} \text { Perkin-Elmer }{ }^{\mathrm{m}}\end{array}$} \\
\hline
\end{tabular}


Table A-58. Tank 241-S-101 Analytical Results: Density/Specific Gravity. (2 sheets)

\begin{tabular}{|c|c|c|c|c|c|c|c|}
\hline Shando & 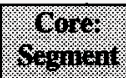 & olom & Resilim & $8010116 \cdot 1+4$ & 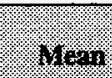 & Wol & 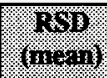 \\
\hline Wolids & & 1. & 96113 & 8 113 & $8111 \%$ & 06111 & \% \\
\hline S96T001897 & 138: 2R1 & Lower $1 / 2$ & 1.500 & -- & $\ldots$ & \multirow[t]{17}{*}{1.65} & \multirow[t]{17}{*}{2.0} \\
\hline S96T001888 & \multirow[t]{2}{*}{$138: 5$} & Upper $1 / 2$ & 1.650 & --- & -- & & \\
\hline S96T001896 & & Lower $1 / 2$ & 1.630 & -- & --- & & \\
\hline S96T001953 & \multirow[t]{2}{*}{ 138: 6} & Upper $1 / 2$ & 1.660 & --- & --- & & \\
\hline S96T001954 & & Lower $1 / 2$ & 1.670 & --- & -- & & \\
\hline S96T002164 & \multirow[t]{2}{*}{ 138: 7} & Upper $1 / 2$ & 1.740 & --- & --- & & \\
\hline S96T002165 & & Lower $1 / 2$ & 1.780 & -- & -- & & \\
\hline S96T002002 & \multirow[t]{2}{*}{ 138: 8} & Upper $1 / 2$ & 1.800 & -- & $\cdots$ & & \\
\hline S96T002003 & & Lower $1 / 2$ & 1.770 & --- & --- & & \\
\hline S96T002174 & \multirow[t]{2}{*}{ 138: 9} & Upper $1 / 2$ & $\mathrm{~N} / \mathrm{A}$ & & & & \\
\hline S96T002175 & & Lower $1 / 2$ & N/A & & & & \\
\hline S96T002057 & \multirow[t]{2}{*}{ 142: 1} & Upper $1 / 2$ & 1.530 & --- & --- & & \\
\hline S96T00205 & & Lower $1 / 2$ & $\mathrm{~N} / \mathrm{A}$ & & & & \\
\hline S96T002298 & \multirow[t]{2}{*}{ 142: 2} & Upper $1 / 2$ & 1.520 & --- & -- & & \\
\hline S96T002299 & & Lower $1 / 2$ & 1.550 & -- & - & & \\
\hline S96T002300 & \multirow[t]{2}{*}{$142: 3$} & Upper $1 / 2$ & 1.580 & -- & --- & & \\
\hline S96T002301 & & Lower $1 / 2$ & 1.620 & --- & --- & & \\
\hline
\end{tabular}


Table A-58. Tank 241-S-101 Analytical Results: Density/Specific Gravity. (2 sheets)

\begin{tabular}{|c|c|c|c|c|c|c|c|}
\hline OHanilo & 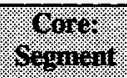 & 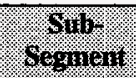 & Pravill & Bopligite & 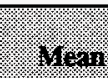 & Worll & $(1+1)$ \\
\hline (Solu: & & & Ofin & G111\% & 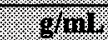 & (6) & $\%$ \\
\hline S96T002058 & \multirow[t]{2}{*}{ 142: 4} & Upper $1 / 2$ & 1.580 & $-\rightarrow$ & --- & \multirow[t]{10}{*}{ Cont. } & \multirow[t]{10}{*}{ Cont. } \\
\hline S96T002059 & & Lower $1 / 2$ & 1.620 & --- & --- & & \\
\hline S96T002060 & \multirow[t]{2}{*}{$142: 5$} & Upper $1 / 2$ & 1.660 & --- & -- & & \\
\hline S96T002061 & & Lower $1 / 2$ & 1.710 & --- & --- & & \\
\hline S96T002062 & \multirow[t]{2}{*}{$142: 6$} & Upper $1 / 2$ & 1.680 & --- & --- & & \\
\hline S96T002063 & & Lower $1 / 2$ & 1.710 & -- & --- & & \\
\hline S96T002064 & \multirow[t]{2}{*}{ 142: 7} & Upper $1 / 2$ & 1.740 & -- & $\ldots$ & & \\
\hline S96T002065 & & Lower $1 / 2$ & N/A & & & & \\
\hline S96T002066 & \multirow[t]{2}{*}{ 142: 8} & Upper $1 / 2$ & N/A & & & & \\
\hline \$96T002067 & & Lower $1 / 2$ & N/A & & & & \\
\hline \multicolumn{3}{|c|}{ Sollits connorsites } & $9 \min$ & s/mi: & 871113 & 94111 & \%) \\
\hline S96T002720 & 138 & N/A & 1.700 & --- & --- & \multirow[t]{2}{*}{1.65} & \multirow[t]{2}{*}{3.3} \\
\hline S96T002727 & 142 & N/A & 1.590 & --- & --- & & \\
\hline \multicolumn{3}{|c|}{ Mganable fiquilo } & $9 / 31$ & 4011\% & S/1011 & $86 n$ & \% \\
\hline S96T001886 & 138: 1R & DL & 1.342 & 1.350 & 1.346 & \multirow[t]{3}{*}{1.36} & \multirow[t]{3}{*}{0.7} \\
\hline S96T001909 & 138: $2 \mathrm{R} 1$ & DL & 1.356 & 1.362 & 1.359 & & \\
\hline \$96T002043 & 138: $3 \mathrm{R}$ & DL & 1.381 & 1.378 & 1.379 & & \\
\hline
\end{tabular}


APPENDIX B

RESULTS OF HYDROSTATIC HEAD FLUID CONTAMINATION CHECK FOR SINGLE-SHELL TANK 241-S-101 
WHC-SD-WM-ER-613 Rev. 0

This page intentionally left blank. 


\section{B.0 RESULTS OF HYDROSTATIC HEAD FLUID CONTAMINATION CHECK FOR SINGLE-SHELL TANK 241-S-101}

\section{B.1 INTRODUCTION AND ANALYTE TABLE DESCRIPTION}

Appendix B reports the results of the wash water contamination check for the 1996 core sampling event. Lithium and bromide were measured to detect any contamination of the waste samples by the wash water.

The "Sample Number" column in each of the data tables lists the laboratory sample identification number. Sampling rationale, locations, and a description of the sampling event are discussed in Section 3.0.

The "Core:Segment" column specifies the core and segment from which the sample was derived.

The "Subsegment" column specifies the segment portion (subsegment) from which the sample was taken. This can be the entire segment (whole), the drainable liquid portion (DL), upper or lower half segment portions, or quarter segment portions (A refers to top quarter, $\mathrm{B}$ refers to second quarter).

The "Result" and "Duplicate" columns are self-explanatory. The "Sample Mean" column lists the average of the result and duplicate values. If the result and duplicate values were both detected, or one of the two values is detected and the other non-detected, then the mean is expressed as a detected value. If the result and duplicate values were both nondetected, then the mean is expressed as a nondetected. The result and duplicate values, as well as the result/duplicate means, are reported in the tables exactly as found in the original laboratory data package. The means may appear to have been rounded up in some cases and rounded down in others. This is because the analytical results given in the tables may have fewer significant figures than originally reported, not because the means were incorrectly calculated.

The four quality control parameters assessed on the tank 241-S-101 samples were standard recoveries, spike recoveries, duplicate analyses (RPDs), and blanks. These were summarized in Section 5.1.2. More specific information is provided in the following appendix tables. Sample and duplicate pairs in which any of the QC parameters were outside their specified limits are superscripted in the "Sample Mean" column as follows:

QC:a -- indicates that the standard recovery was below the QC range.

$\mathrm{QC}: \mathrm{b}$-- indicates that the standard recovery was above the QC range.

$\mathrm{QC}: \mathrm{c}$-- indicates that the spike recovery was below the QC range.

$\mathrm{QC}: \mathrm{d}$-- indicates that the spike recovery was above the $\mathrm{QC}$ range.

QC:e -- indicates that the RPD was greater than the QC limit range.

QC:f -- indicates blank contamination. 
Table B-1. Tank 241-S-101 Analytical Results: Lithium. (3 sheets)

\begin{tabular}{|c|c|c|c|c|c|}
\hline Shomols & heomert & somons & resill & Bupligate & Mraple \\
\hline \multicolumn{2}{|c|}{ Solify r fusion allest } & & $109 \%$ & $\%$ & 489 \\
\hline S96T001903 & 138: 2R1 & Lower $1 / 2$ & $<197$ & $<186$ & $<191.5$ \\
\hline S96T002040 & 138: 3AR & Whole & $<204$ & $<191$ & $<197.5$ \\
\hline S96T001891 & \multirow[t]{2}{*}{ 138: 5} & Upper $1 / 2$ & $<210$ & $<212$ & $<211$ \\
\hline S96T001902 & & Lower $1 / 2$ & $<181$ & $<176$ & $<178.5$ \\
\hline S96T002045 & \multirow[t]{2}{*}{ 138: 6} & Upper $1 / 2$ & $<192$ & $<189$ & $<190.5$ \\
\hline S96T002047 & & Lower $1 / 2$ & $<207$ & $<191$ & $<199$ \\
\hline S96T002193 & \multirow[t]{2}{*}{ 138: 7} & Upper $1 / 2$ & $<208$ & $<212$ & $<210$ \\
\hline S96T002202 & & Lower $1 / 2$ & $<200$ & $<200$ & $<200$ \\
\hline S96T002046 & \multirow[t]{2}{*}{ 138: 8} & Upper $1 / 2$ & $<205$ & $<209$ & $<207$ \\
\hline S96T002048 & & Lower $1 / 2$ & $<189$ & $<204$ & $<196.5$ \\
\hline S96T002194 & \multirow[t]{2}{*}{ 138: 9} & Upper $1 / 2$ & $<193$ & $<205$ & $<199$ \\
\hline S96T002199 & & Lower $1 / 2$ & $<213$ & $<208$ & $<210.5$ \\
\hline S96T002090 & 142: 1 & Upper $1 / 2$ & $<206$ & $<205$ & $<205.5$ \\
\hline S96T002310 & \multirow[t]{2}{*}{ 142: 2} & Upper $1 / 2$ & $<188$ & $<185$ & $<186.5$ \\
\hline S96T002316 & & Lower $1 / 2$ & $<204$ & $<203$ & $<203.5$ \\
\hline S96T002311 & \multirow[t]{2}{*}{ 142: 3} & Upper 1/2 & $<202$ & $<206$ & $<204$ \\
\hline S96T002319 & & Lower $1 / 2$ & $<195$ & $<191$ & $<193$ \\
\hline S96T002092 & \multirow[t]{2}{*}{ 142: 4} & Upper $1 / 2$ & $<202$ & $<200$ & $<201$ \\
\hline S96T002105 & & Lower $1 / 2$ & $<200$ & $<206$ & $<203$ \\
\hline S96T002093 & \multirow[t]{2}{*}{$142: 5$} & Upper $1 / 2$ & $<194$ & $<187$ & $<190.5$ \\
\hline S96T002106 & & Lower $1 / 2$ & $<204$ & $<187$ & $<195.5$ \\
\hline S96T002094 & \multirow[t]{2}{*}{ 142: 6} & Upper $1 / 2$ & $<207$ & $<203$ & $<205$ \\
\hline S96T002091 & & Lower $1 / 2$ & $<206$ & $<205$ & $<205.5$ \\
\hline
\end{tabular}


WHC-SD-WM-ER-613 Rev. 0

Table B-1. Tank 241-S-101 Analytical Results: Lithium. (3 sheets)

\begin{tabular}{|c|c|c|c|c|c|}
\hline Mrando & orogringt & o. & thesult & 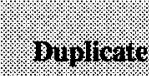 & Souple \\
\hline \multicolumn{3}{|c|}{ 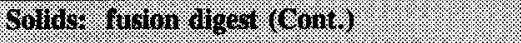 } & 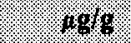 & 483 & 6098 \\
\hline S96T002095 & \multirow[t]{2}{*}{ 142: 7} & Upper $1 / 2$ & $<199$ & $<201$ & $<200$ \\
\hline S96T002107 & & Lower $1 / 2$ & $<215$ & $<217$ & $<216$ \\
\hline S96T002096 & \multirow[t]{2}{*}{ 142: 8} & Upper $1 / 2$ & $<199$ & $<198$ & $<198.5$ \\
\hline S96T002108 & & Lower $1 / 2$ & $<204$ & $<200$ & $<202$ \\
\hline \multicolumn{3}{|c|}{ Solid, acti alest. } & 498 & 498 & 90 \\
\hline S96T001905 & 138: 2R1 & Lower $1 / 2$ & $<3.81$ & $<3.87$ & $<3.84$ \\
\hline S96T001892 & \multirow[t]{2}{*}{ 138: 5} & Upper $1 / 2$ & $<3.82$ & $<4.03$ & $<3.925$ \\
\hline S96T001904 & & Lower $1 / 2$ & $<3.58$ & $<3.92$ & $<3.75$ \\
\hline S96T002049 & \multirow[t]{2}{*}{ 138: 6} & Upper $1 / 2$ & $<3.76$ & $<3.89$ & $<3.825$ \\
\hline S96T002050 & & Lower $1 / 2$ & $<3.71$ & $<4.09$ & $<3.9$ \\
\hline S96T002195 & \multirow[t]{2}{*}{ 138: 7} & Upper $1 / 2$ & $<4.4$ & $<4.49$ & $<4.445$ \\
\hline S96T002203 & & Lower $1 / 2$ & $<3.91$ & $<4.08$ & $<3.995$ \\
\hline S96T002051 & \multirow[t]{2}{*}{ 138: 8} & Upper $1 / 2$ & $<3.69$ & $<3.8$ & $<3.745$ \\
\hline S96T002052 & & Lower $1 / 2$ & $<3.79$ & $<3.91$ & $<3.85$ \\
\hline S96T002196 & \multirow[t]{2}{*}{ 138: 9} & Upper $1 / 2$ & 34.4 & 24.9 & $29.65^{\mathrm{QC}: \mathrm{e}}$ \\
\hline S96T002200 & & Lower $1 / 2$ & $<3.68$ & $<3.98$ & $<3.83$ \\
\hline S96T002097 & 142: 1 & Upper $1 / 2$ & $<3.57$ & $<3.57$ & $<3.57$ \\
\hline S96T002312 & \multirow[t]{2}{*}{ 142: 2} & Upper $1 / 2$ & $<4.09$ & $<3.68$ & $<3.885$ \\
\hline S96T002317 & & Lower $1 / 2$ & $<3.73$ & $<3.91$ & $<3.82$ \\
\hline S96T002313 & \multirow[t]{2}{*}{$142: 3$} & Upper $1 / 2$ & $<4.1$ & $<4.05$ & $<4.075$ \\
\hline S96T002320 & & Lower $1 / 2$ & $<4.17$ & $<4.01$ & $<4.09$ \\
\hline S96T002109 & \multirow[t]{2}{*}{ 142: 4} & Upper $1 / 2$ & $<4.01$ & $<4.09$ & $<4.05$ \\
\hline S96T002110 & & Lower $1 / 2$ & $<3.93$ & $<3.86$ & $<3.895$ \\
\hline
\end{tabular}


Table B-1. Tank 241-S-101 Analytical Results: Lithium. (3 sheets)

\begin{tabular}{|c|c|c|c|c|c|}
\hline Monger & Morer & Somer & 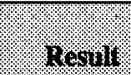 & Miplicate & 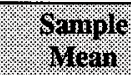 \\
\hline \multicolumn{3}{|c|}{ 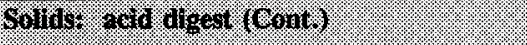 } & 4989 & $108 \%$ & agro \\
\hline S96T002111 & \multirow[t]{2}{*}{$142: 5$} & Upper $1 / 2$ & $<3.53$ & $<3.86$ & $<3.695$ \\
\hline S96T002112 & & Lower $1 / 2$ & $<3.57$ & $<3.82$ & $<3.695$ \\
\hline S96T002113 & \multirow[t]{2}{*}{$142: 6$} & Upper $1 / 2$ & $<3.89$ & $<4.48$ & $<4.185$ \\
\hline S96T002098 & & Lower $1 / 2$ & $<3.93$ & $<4.08$ & $<4.005$ \\
\hline S96T002114 & \multirow[t]{2}{*}{$142: 7$} & Upper $1 / 2$ & $<3.96$ & $<4.02$ & $<3.99$ \\
\hline S96T002115 & & Lower $1 / 2$ & $<3.67$ & $<3.58$ & $<3.625$ \\
\hline S96T002116 & \multirow[t]{2}{*}{$142: 8$} & Upper $1 / 2$ & $<3.71$ & $<3.6$ & $<3.655$ \\
\hline S96T002117 & & Lower $1 / 2$ & $<3.75$ & $<3.7$ & $<3.725$ \\
\hline \multicolumn{3}{|c|}{ 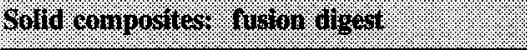 } & 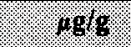 & 68 & $x_{0}$ \\
\hline S96T002723 & 138 & N/A & $<209$ & $<217$ & $<213$ \\
\hline S96T002731 & 142 & N/A & $<204$ & $<210$ & $<207$ \\
\hline \multicolumn{3}{|c|}{ 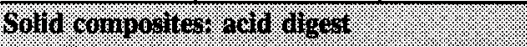 } & 1989 & 140\% & 1098 \\
\hline S96T002724 & 138 & N/A & $<6.86$ & $<6.82$ & $<6.84$ \\
\hline S96T002733 & 142 & N/A & $<6.77$ & $<6.35$ & $<6.56$ \\
\hline \multicolumn{3}{|c|}{ 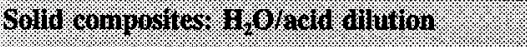 } & 48 & 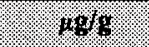 & 6089 \\
\hline S96T002726 & 138 & N/A & $<5.62$ & $<5.46$ & $<5.54$ \\
\hline S96T002736 & 142 & N/A & $<5.48$ & $<5.04$ & $<5.26$ \\
\hline \multicolumn{3}{|c|}{ Mranalouring } & $\mathrm{H}_{\mathrm{m}}$ & M/n & pelut \\
\hline S96T001886 & 138: $1 \mathrm{R}$ & $\mathrm{DL}$ & $<4.01$ & $<4.01$ & $<4.01$ \\
\hline S96T001909 & 138: $2 \mathrm{R} 1$ & $\mathrm{DL}$ & $<4.01$ & $<4.01$ & $<4.01$ \\
\hline S96T002043 & 138: 3R & $\mathrm{DL}$ & $<4.01$ & $<4.01$ & $<4.01$ \\
\hline
\end{tabular}


Table B-2. Tank 241-S-101 Analytical Results: Bromide. (2 sheets)

\begin{tabular}{|c|c|c|c|c|c|}
\hline $\begin{array}{l}\text { Sample: } \\
\text { Tumber }\end{array}$ & $\begin{array}{l}\text { Gorro: } \\
\text { Sogrnent }\end{array}$ & sing sula & Rasill & Duplicate & $\begin{array}{l}\text { Sample } \\
\text { Mean }\end{array}$ \\
\hline \multicolumn{2}{|c|}{ Solters water digert } & & $118 \mathrm{~g}$ & 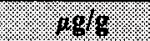 & $148 \%$ \\
\hline S96T001907 & 138: $2 \mathrm{R} 1$ & Lower $1 / 2$ & $<1,088$ & $<1,030$ & $<1,059$ \\
\hline S96T001893 & \multirow[t]{2}{*}{ 138: 5} & Upper $1 / 2$ & $<882.2$ & $<948$ & $<915.1$ \\
\hline S96T001906 & & Lower $1 / 2$ & $<957.6$ & $<882$ & $<919.8$ \\
\hline S96T003326 & \multirow[t]{2}{*}{ 138: 6} & Upper $1 / 2$ & $<498.8$ & $<490$ & $<494.4$ \\
\hline S96T003327 & & Lower $1 / 2$ & $<520.1$ & $<515$ & $<517.55$ \\
\hline S96T003497 & \multirow[t]{2}{*}{ 138: 7} & Upper $1 / 2$ & $<525.6$ & $<526$ & $<525.8$ \\
\hline S96T003498 & & Lower $1 / 2$ & $<355.1$ & $<352$ & $<353.55$ \\
\hline S96T003463 & \multirow[t]{2}{*}{ 138: 8} & Upper $1 / 2$ & $<309.4$ & $<309$ & $<309.2$ \\
\hline S96T003464 & & Lower $1 / 2$ & $<367.9$ & $<369$ & $<368.45$ \\
\hline S96T003461 & \multirow[t]{2}{*}{ 138: 9} & Upper $1 / 2$ & $<360.8$ & $<350$ & $<355.4$ \\
\hline S96T003462 & & Lower $1 / 2$ & $<346.6$ & $<333$ & $<339.8$ \\
\hline S96T002099 & 142: 1 & Upper $1 / 2$ & $<508.1$ & $<527$ & $<517.55$ \\
\hline S96T002314 & \multirow[t]{2}{*}{$142: 2$} & Upper $1 / 2$ & $<494.5$ & $<504$ & $<499.25$ \\
\hline S96T002318 & & Lower $1 / 2$ & $<497.4$ & $<508$ & $<502.7$ \\
\hline \$96T002315 & \multirow[t]{2}{*}{$142: 3$} & Upper $1 / 2$ & $<528.9$ & $<540$ & $<534.45$ \\
\hline S96T003499 & & Lower $1 / 2$ & $<342.4$ & $<338$ & $<340.2$ \\
\hline S96T002118 & \multirow[t]{2}{*}{$142: 4$} & Upper $1 / 2$ & $<524.3$ & $<510$ & $<517.15$ \\
\hline S96T002119 & & Lower $1 / 2$ & $<503.4$ & $<500$ & $<501.7$ \\
\hline S96T002120 & \multirow[t]{2}{*}{$142: 5$} & Upper $1 / 2$ & $<486.4$ & $<512$ & $<499.2$ \\
\hline S96T002121 & & Lower $1 / 2$ & $<496.2$ & $<482$ & $<489.1$ \\
\hline S96T002122 & 142: 6 & Upper $1 / 2$ & $<527.9$ & $<538$ & $<532.95$ \\
\hline
\end{tabular}


Table B-2. Tank 241-S-101 Analytical Results: Bromide. (2 sheets)

\begin{tabular}{|c|c|c|c|c|c|}
\hline $\begin{array}{l}\text { Sample: } \\
\text { Tumber }\end{array}$ & $\begin{array}{l}\text { Corver } \\
\text { segment }\end{array}$ & Sout & resill & Diplicate. & $\begin{array}{l}\text { Sample } \\
\text { Mena }\end{array}$ \\
\hline \multicolumn{3}{|c|}{ Solld, vater algest? } & 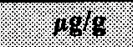 & 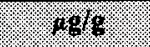 & 4.989 \\
\hline S96T002100 & & Lower $1 / 2$ & $<520.1$ & $<525$ & $<522.55$ \\
\hline S96T002123 & \multirow[t]{2}{*}{ 142: 7} & Upper $1 / 2$ & $<540.7$ & $<487$ & $<513.85$ \\
\hline S96T002124 & & Lower $1 / 2$ & $<471$ & $<486$ & $<478.5$ \\
\hline S96T002125 & \multirow[t]{2}{*}{$142: 8$} & Upper $1 / 2$ & $<265.6$ & $<257$ & $<261.3$ \\
\hline S96T002126 & & Lower $1 / 2$ & $<537.6$ & $<546$ & $<541.8$ \\
\hline \multicolumn{3}{|c|}{ Solin composites- valer digest. } & 18989 & 1858: & $148 / 8$ \\
\hline \$96T002725 & 138 & N/A & $<579.5$ & $<563$ & $<571.25$ \\
\hline S96T002735 & 142 & N/A & $<564.9$ & $<520$ & $<542.45$ \\
\hline \multicolumn{3}{|c|}{ Drainable liguids } & 48: in: & inglin. & igini. \\
\hline S96T001886 & 138: $1 \mathrm{R}$ & $\mathrm{DL}$ & $<1,285$ & $<1,290$ & $<1,287.5$ \\
\hline S96T001909 & 138: $2 \mathrm{R} 1$ & DL & $<1,285$ & $<1,290$ & $<1,287.5$ \\
\hline S96T002043 & 138: $3 R$ & DL & 993.7 & 999 & 996.35 \\
\hline
\end{tabular}


WHC-SD-WM-ER-613 Rev. 0

APPENDIX C

EARLIER SAMPLING EVENTS

C-1 
WHC-SD-WM-ER-613 Rev. 0

This page intentionally left blank. 


\section{C.0 ANALYTICAL RESULTS FROM HISTORICAL SAMPLING EVENTS}

Appendix C presents analytical results from the historical sampling events of tank 241-S-101. Because of the active process history of the tank, only the results from the 1991 sampling event (presented in Table $\mathrm{C}-1$ ) have been deemed representative of the current tank contents. Data from the remaining sampling events have been included in this appendix for informational purposes only. A description of the sampling event can be found in the respective source document, which is listed in the footnotes to each table. 
WHC-SD-WM-ER-613 Rev. 0

Table C-1. Sample from Tank 241-S-101. ${ }^{1}$

\begin{tabular}{|c|c|c|}
\hline \multicolumn{3}{|c|}{ Sample Status Report } \\
\hline \multicolumn{3}{|c|}{ Sample No. T-8579 } \\
\hline \multicolumn{3}{|c|}{ Received: December 17, 1991 } \\
\hline Physical Data \\
\hline Appearance/OTR & Clear, yellow, no solids \\
\hline Radiation & $1 \mathrm{rad} / \mathrm{hr}$ \\
\hline $\mathrm{pH}$ & $13.4 \quad$ Chemical Analysis \\
\hline Lab Value & Lab Unit \\
\hline Component & 0.576 & $\underline{\mathrm{M}}$ \\
\hline $\mathrm{Al}$ & \multicolumn{2}{|c|}{ Incomplete } \\
\hline $\mathrm{CN}$ & 4.66 & $\mathrm{~g} / \mathrm{L}$ \\
\hline $\mathrm{TIC}$ & 3.21 & $\mathrm{~g} / \mathrm{L}$ \\
\hline $\mathrm{TOC}$ & 6,640 & $\mathrm{ppm}$ \\
\hline $\mathrm{F}$ & 2.10 & $\underline{\mathrm{M}}$ \\
\hline $\mathrm{NO}_{2}$ & $1.97 \times 10^{5}$ & $\mathrm{ppm}$ \\
\hline $\mathrm{NO}_{3}$ & & \\
\hline
\end{tabular}

Notes:

TIC $=$ total inorganic carbon

'WHC (1991) 
Table C-2. Sample from Tank 241-S-101.'

\begin{tabular}{|c|c|c|}
\hline \multicolumn{3}{|c|}{ Waste Tank 241-S-101 } \\
\hline \multicolumn{3}{|c|}{ Sample T-9715, Received November 19, 1975} \\
\hline \multicolumn{3}{|c|}{ Plyysical Data } \\
\hline Visual - OTR & \multicolumn{2}{|c|}{ Yellow/black with suspended solids } \\
\hline Radiation & \multicolumn{2}{|l|}{$2 \mathrm{rad} / \mathrm{hr}$} \\
\hline $\mathrm{pH}$ & \multicolumn{2}{|l|}{13.6} \\
\hline Percent Water & \multicolumn{2}{|l|}{42.82} \\
\hline Specific Gravity & \multicolumn{2}{|l|}{1.51 at $64.5^{\circ} \mathrm{C}$} \\
\hline \multicolumn{3}{|c|}{ Ghericul Amilgsis: } \\
\hline Component & Lab Value & Lab Unit \\
\hline $\mathrm{OH}$ & 3.60 & $\underline{\mathbf{M}}$ \\
\hline $\mathrm{Al}$ & 1.82 & $\underline{\mathbf{M}}$ \\
\hline $\mathrm{NO}_{2}$ & 0.318 & $\underline{\mathbf{M}}$ \\
\hline $\mathrm{NO}_{3}$ & 4.68 & $\underline{\mathbf{M}}$ \\
\hline $\mathrm{CO}_{3}$ & 0.318 & $\underline{\mathbf{M}}$ \\
\hline $\mathrm{NH}_{4}$ & 0.0194 & $\underline{\mathbf{M}}$ \\
\hline (2.: & \multicolumn{2}{|c|}{ Radiological Analysis: } \\
\hline Component & Lab Value & Lab Unit \\
\hline${ }^{134} \mathrm{Cs}$ & 8,210 & $\mu \mathrm{Ci} / \mathrm{gal}$ \\
\hline${ }^{137} \mathrm{Cs}$ & $2.44 \times 10^{6}$ & $\mu \mathrm{Ci} / \mathrm{gal}$ \\
\hline${ }^{103} \mathrm{Ru}$ & $<1,270$ & $\mu \mathrm{Ci} / \mathrm{gal}$ \\
\hline
\end{tabular}

Note:

'Wheeler (1975) 
WHC-SD-WM-ER-613 Rev. 0

Table C-3. Sludge Sample from Tank 241-S-101. ${ }^{1}$

\begin{tabular}{|c|c|c|}
\hline \multicolumn{3}{|c|}{ Waste Tank 241-S-101 } \\
\hline \multicolumn{3}{|c|}{ Received June 4, 1975} \\
\hline \multicolumn{3}{|c|}{ Plyysical Data } \\
\hline Percent Water & 37.4 & \\
\hline Bulk Density & 1.52 & \\
\hline Particle Density & 1.91 & \\
\hline \multicolumn{3}{|c|}{ Ghermical Analyors. } \\
\hline Component & Lab Value & Lab Unit \\
\hline $\mathrm{Al}$ & 4.75 & $\underline{\mathbf{M}}$ \\
\hline $\mathrm{Fe}$ & 0.08 & $\underline{\mathrm{M}}$ \\
\hline $\mathrm{NO}_{2}$ & $<0.2$ & $\underline{\mathrm{M}}$ \\
\hline $\mathrm{NO}_{3}$ & 9.08 & $\underline{\mathbf{M}}$ \\
\hline $\mathrm{PO}_{4}$ & 0.08 & $\underline{\mathbf{M}}$ \\
\hline $\mathrm{Mg}$ & 0.05 & $\underline{M}$ \\
\hline $\mathbf{M n}$ & 0.08 & $\underline{\mathrm{M}}$ \\
\hline \multicolumn{3}{|c|}{ Rabliologied I Gnal ysis } \\
\hline Component & Lab Value & Lab Unit \\
\hline $\mathrm{Pu}$ & $5.97 \times 10^{6}$ & $\mathrm{~g} / \mathrm{L}$ \\
\hline${ }^{89+90} \mathrm{Sr}$ & $1.01 \times 10^{6}$ & $\mu \mathrm{Ci} / \mathrm{L}$ \\
\hline${ }^{137} \mathrm{Cs}$ & $2.95 \times 10^{5}$ & $\mu \mathrm{Ci} / \mathrm{L}$ \\
\hline
\end{tabular}

Note:

${ }^{1}$ Horton (1975) 
Table C-4. Sample from Tank 241-S-101. ${ }^{1}$

\begin{tabular}{|c|c|c|}
\hline \multicolumn{3}{|c|}{ Waste Tank 241-S-101 } \\
\hline \multicolumn{3}{|c|}{ Sample T-8084 } \\
\hline \multicolumn{3}{|c|}{ Received September 13, 1974} \\
\hline \multicolumn{3}{|c|}{ 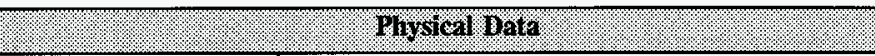 } \\
\hline Visual - OTR & \multicolumn{2}{|l|}{ Milky yellow, no solids } \\
\hline Radiation & \multicolumn{2}{|l|}{$250 \mathrm{mrad} / \mathrm{hr}$} \\
\hline $\mathrm{pH}$ & \multicolumn{2}{|l|}{14} \\
\hline Percent Water & \multicolumn{2}{|l|}{81.90} \\
\hline Specific Gravity & \multicolumn{2}{|l|}{1.205} \\
\hline 1 & \multicolumn{2}{|l|}{ 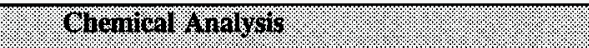 } \\
\hline Component & \multicolumn{2}{|c|}{ Lab Value } \\
\hline $\mathrm{OH}$ & 0.415 & $\underline{\mathbf{M}}$ \\
\hline $\mathrm{Al}$ & 0.333 & $\underline{\mathrm{M}}$ \\
\hline $\mathrm{Na}$ & 2.90 & $\underline{\mathrm{M}}$ \\
\hline $\mathrm{NO}_{2}$ & 0.197 & $\underline{\mathrm{M}}$ \\
\hline $\mathrm{NO}_{3}$ & 1.53 & $\underline{\mathrm{M}}$ \\
\hline $\mathrm{SO}_{4}$ & 0.00878 & $\underline{\mathbf{M}}$ \\
\hline $\mathrm{PO}_{4}$ & 0.0934 & $\underline{\mathrm{M}}$ \\
\hline $\mathrm{CO}_{3}$ & 0.111 & $\underline{\mathrm{M}}$ \\
\hline$\vec{F}$ & 0.00355 & $\underline{\mathrm{M}}$ \\
\hline & gRariblogical onal & \\
\hline Component & Lab Value & Lab Unit \\
\hline $\mathrm{Pu}$ & $<4.43 \times 10^{-6}$ & g/gal \\
\hline${ }^{134} \mathrm{Cs}$ & 2180 & $\mu \mathrm{Ci} /$ gal \\
\hline${ }^{137} \mathrm{Cs}$ & $4.05 \times 10^{5}$ & $\mu \mathrm{Ci} /$ gal \\
\hline${ }^{89+90} \mathrm{Sr}$ & 409 & $\mu \mathrm{Ci} / \mathrm{gal}$ \\
\hline
\end{tabular}

Note:

'Wheeler (1974) 
WHC-SD-WM-ER-613 Rev. 0

Table C-5. Sample from Tank 241-S-101. ${ }^{1}$

\begin{tabular}{|c|c|c|}
\hline \multicolumn{3}{|c|}{ 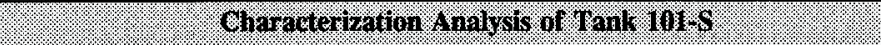 } \\
\hline Component & Lab Value & Lab Unit \\
\hline Specific Gravity & 1.412 & --- \\
\hline Viscosity at $50^{\circ} \mathrm{C}$ & 2.23 & --- \\
\hline $\mathrm{CO}_{3}$ & 0.011 & $\underline{\mathbf{M}}$ \\
\hline $\mathrm{NO}_{3}$ & 3.82 & $\underline{\mathbf{M}}$ \\
\hline $\mathrm{NO}_{2}$ & 0.642 & $\underline{\mathbf{M}}$ \\
\hline TAD & 3.62 & --- \\
\hline $\mathrm{Al}$ & 1.41 & $\underline{\mathbf{M}}$ \\
\hline $\mathrm{Na}$ & 9.01 & $\underline{\mathbf{M}}$ \\
\hline${ }^{137} \mathrm{Cs}$ & 155 & $\mu \mathrm{Ci} / \mathrm{mL}$ \\
\hline
\end{tabular}

Note:

${ }^{1}$ Puryear (1971) 


\begin{tabular}{|c|c|c|c|c|c|}
\hline \multicolumn{6}{|c|}{ DISTRIBUTION SHEET } \\
\hline \multirow{2}{*}{$\begin{array}{l}\text { To } \\
\text { Distribution }\end{array}$} & \multirow{2}{*}{\multicolumn{3}{|c|}{$\begin{array}{l}\text { Data Ass } \\
\text { Interp }\end{array}$}} & \multicolumn{2}{|l|}{ Page 1 of 4} \\
\hline & & & & \multicolumn{2}{|c|}{ Date $\quad 08 / 29 / 96$} \\
\hline \multicolumn{4}{|c|}{ Project Title/Work Order } & \multicolumn{2}{|c|}{ EDT No. $\quad$ EDT-617535 } \\
\hline \multicolumn{4}{|c|}{$\begin{array}{l}\text { Tank Characterization Report for Sing } 7 \text {-She11 Tank } 241-S-101 \text {, } \\
\text { WHC-SD-WM-ER-613. Rev. } 0\end{array}$} & \multicolumn{2}{|c|}{ ECN No. N/A } \\
\hline Name & MSIN & $\begin{array}{c}\text { Text } \\
\text { With All } \\
\text { Attach. }\end{array}$ & Text Only & $\begin{array}{l}\text { Attach./ } \\
\text { Appendix } \\
\text { Only }\end{array}$ & $\begin{array}{l}\text { EDT/ECN } \\
\text { Only }\end{array}$ \\
\hline
\end{tabular}

\section{OFFSITE}

Sandia National Laboratory

P. 0. Box 5800

MS-0744, Dept. 6404

Albuquerque. NM 87815

D. Powers

Nuclear Consulting Services Inc.

P. 0. Box 29151

Columbus. OH 43229-01051

J. L. Kovach

Chemical Reaction Sub-TAP

P.0. Box 271

Lindsborg. KS 67456

B. C. Hudson

Tank Characterization Panel

Senior Technical Consultant

Contech

7309 Indian School Road

Albuquerque. NM 87110

J. Arvisu

$x$

U. S. Department of Energy - Headquarters

office of Environmental Restoration and Waste Management EM-563

12800 Middlebrook Road

Germantown. MD 20874

J. A. Poppitti

$x$

$\underline{\text { Jacobs Enqineering Group }}$

B5-36

$x$ 


\begin{tabular}{|c|c|c|c|c|c|}
\hline \multicolumn{6}{|c|}{ DISTRIBUTION SHEET } \\
\hline To & \multirow{2}{*}{\multicolumn{3}{|c|}{ From }} & \multicolumn{2}{|l|}{ Page 2 of 4} \\
\hline Distribution & & & & Date $\quad 08$ & $08 / 29 / 96$ \\
\hline \multicolumn{4}{|l|}{ Project Title/Work Order } & \multicolumn{2}{|c|}{ EDT No. EDT-617535 } \\
\hline \multicolumn{4}{|c|}{$\begin{array}{l}\text { Tank Characterization Report for Single-Shell Tank 241-S-101, } \\
\text { WHC-SD-WM-ER-613. Rev. } 0\end{array}$} & \multicolumn{2}{|c|}{ ECN No. N/A } \\
\hline Name & MSIN & $\begin{array}{c}\text { Text } \\
\text { With All } \\
\text { Attach. }\end{array}$ & Text Only & $\begin{array}{l}\text { Attach./ } \\
\text { Appendix } \\
\text { Only }\end{array}$ & $\begin{array}{l}\text { EDT/ECN } \\
\text { Only }\end{array}$ \\
\hline
\end{tabular}

\section{SAIC}

20300 Century Boulevard, Suite 200-B

Germantown. MD 20874

H. Sutter

555 Quince Orchard Rd., Suite 500

Gaithersburg, MD 20878

P. Szerszen

Los Al amos Laboratory

CST-14 MS-J586

P. 0. Box 1663

Los Alamos. NM 87545

S. F. Agnew (4)

$X$

Los Alamos Technical Associates
T. T. Tran
B1-44
$X$

Ogden Environmental

101 East Wellsian Way

Richland. WA 99352

R. J. Anema

$x$

$\mathrm{CH} 2 \mathrm{M} \mathrm{Hi} 11$

P. 0. BOX 91500

Bellevue, WA 98009-2050

M. McAfee

$X$

Tank Advisory Panel

102 Windham Road

Dak Ridge. TN 37830

D. 0. Campbe11

$x$ 


\begin{tabular}{|c|c|c|c|c|c|}
\hline \multicolumn{6}{|c|}{ DISTRIBUTION SHEET } \\
\hline To & \multirow{2}{*}{\multicolumn{3}{|c|}{ From }} & \multicolumn{2}{|l|}{ Page 3 of 4} \\
\hline Distribution & & & & \multicolumn{2}{|c|}{ Date $\quad 08 / 29 / 96$} \\
\hline \multicolumn{4}{|c|}{ Project Title/Work Order } & \multicolumn{2}{|c|}{ EDT No. EDT-617535 } \\
\hline \multicolumn{4}{|c|}{$\begin{array}{l}\text { Tank Characterization Report for Single-Shell Tank 241-S-101, } \\
\text { WHC-SD-WM-ER-613. Rev. } 0\end{array}$} & \multicolumn{2}{|c|}{ ECN No. N/A } \\
\hline Name & MSIN & $\begin{array}{c}\text { Text } \\
\text { With All } \\
\text { Attach. }\end{array}$ & Text Only & $\begin{array}{l}\text { Attach./ } \\
\text { Appendix } \\
\text { Only }\end{array}$ & $\begin{array}{l}\text { EDT/ECN } \\
\text { Only }\end{array}$ \\
\hline
\end{tabular}

\section{ONSITE}

Boeing Computer Services of Richland
B. G. Lauzon
R1-08
$X$

Department of Energy - Richland Operations
J. F. Thompson
W. S. Liou
S7-54 $\quad X$
N. W. Willis
$\begin{array}{ll}57-54 & x \\ 57-54 & x\end{array}$

ICF-Kaiser Hanford Company

R. L. Newe 11

S3-09 $\quad x$

Pacific Northwest Laboratory
N. G. Colton
K3-75 $\quad X$
J. R. Gormsen
$\mathrm{k} 7-28$
$\mathrm{K} 5-12$
S. A. Hartley
K $7-94$
G. J. Lumetta
P7 -25
A. F. Noonan
K9-81

Westinghouse Hanford Company
H. Babad
D. A. Barnes
G. R. Bloom
W. L. Cowley
L. A. Diaz
G. L. Dunford
E. J. Eberlein
D. B. Engelman
J. S. Garfield
J. D. Guberski
D. C. Hetzer
G. Jansen
G. D. Johnson
N. W Kirch
A. A. Kruger

S7-14

R1-80

H5 -61

A3-37

T6-06

A2-34

R2 -12

L6-37

H5-49

R1-51

T6-09

S6-31

$\mathrm{H} 6-33$

S7 -15

$57-21$

R2-11

R2- 12 


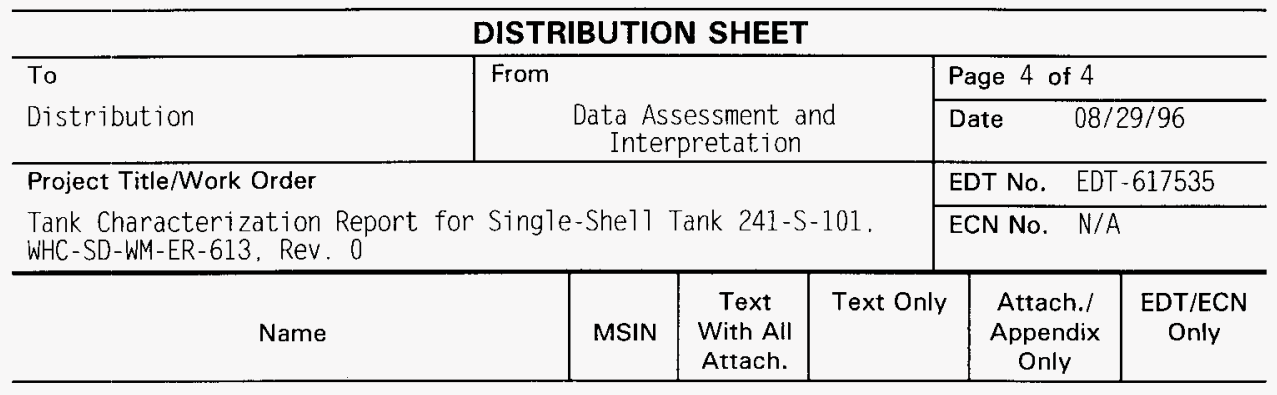

Westinghouse Hanford Company continued

M. J. Kupfer

J. E. Meacham

W. C. Miller

C. T. Narquis

D. E. Place

D. A. Reynolds

L. M. Sasaki

L. W. Sheiton, Jr.

B. C. Simpson

G. L. Troyer

L. R. Webb

K. A. White

Central Files

EDMC

ERC (Environmental Resource Center)

TCRC (10)

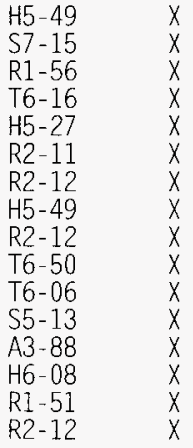

